LUCIANA ESTEVAN CRUZ DE OLIVEIRA

\title{
A INTEGRAÇÃO DA CULPA E DO RISCO NA RESPONSABILIDADE CIVIL DOS ACIDENTES DO TRABALHO
}

\author{
DisSertação - MeStrado \\ Orientador: Prof. Associado EnOQue Ribeiro dos Santos
}

FACULDADE DE DIREITO DA USP

SÃO PAULO

2013 


\title{
A INTEGRAÇÃO DA CULPA E DO RISCO NA RESPONSABILIDADE CIVIL DOS ACIDENTES DO TRABALHO
}

\begin{abstract}
Dissertação apresentada como exigência parcial à obtenção do título de Mestre em Direito, no âmbito do Programa de Pós-Graduação da Faculdade de Direito da Universidade de São Paulo, sob orientação do Professor Associado Enoque Ribeiro dos Santos.
\end{abstract}

FACULDADE DE DIREITO DA USP

SÃO PAULO

2013 
BANCA EXAMINADORA:

Orientador:

Professor Associado Enoque Ribeiro dos Santos

Professor Arguidor:

Professor Arguidor: 


\section{DEDICATÓRIA}

Ao meu marido Gustavo, pela paciência e pelo dom de transformar qualquer atividade difícil em algo tranquilo e alegre,

Aos meus pais, Arnaldo e Lairce, por prover todas as condições necessárias para o início de minha trajetória nos estudos,

A minha avó Natividade, por sua sabedoria e pela disponibilidade em momentos adversos ao longo da caminhada. 


\section{AGRADECIMENTOS}

Ao Professor Enoque Ribeiro dos Santos, exemplo de persistência a ser seguido, agradeço a paciência e confiança depositada desde o início, além das constantes motivações ao longo da árdua tarefa.

Ao Professor Ronaldo Lima dos Santos, pelas objeções pontuais no Exame de Qualificação que mostraram o caminho da cientificidade.

Ao Professor Ari Possidonio Beltran, pela disposição e constante dedicação acadêmica. 


\section{RESUMO}

A ordem jurídica estabelece normas de proteção à saúde e ao meio ambiente do trabalho que impõe deveres aos empregadores e, por outro lado, conferem direitos subjetivos aos trabalhadores a um ambiente laboral salubre.

A falha nessa rede protetiva enseja o acidente do trabalho, que é um evento, súbito ou paulatino, que causa danos morais e patrimoniais à saúde do trabalhador, sendo decorrente do próprio exercício da atividade profissional.

A responsabilidade por esses acidentes trilhou uma evolução desde a perseguição da culpa até sua desconsideração e direcionamento pelo risco. O desequilíbrio provocado pelos acidentes do trabalho fez com que o próprio Estado garantisse o pagamento de um benefício de caráter alimentar aos trabalhadores mutilados, por meio do seguro social. Entretanto, devido à insuficiência desse pagamento pelo ente estatal, o empregado socorrese aos postulados do direito civil para complementar por inteiro sua indenização pelos prejuízos sofridos.

A responsabilidade civil é, atualmente, sedimentada pelo descumprimento de deveres contratuais de segurança pelo empregador e o risco da atividade econômica, haja vista que o empregador que aufere as vantagens deve suportar os ônus.

Em paralelismo à responsabilidade do Estado, a responsabilidade civil do empregador deverá ser garantida por seguro de natureza privada, pois a socialização dos riscos é imprescindível para a manutenção da paz social. Esse sistema misto de indenização dos prejuízos e pagamento de benefícios pelo Estado coaduna-se com o preceito constitucional que determina que a cobertura de acidente de trabalho seja feita, concorrentemente, tanto pela previdência social quanto pelo setor privado.

Além disso, o artigo $7^{\circ}$, inciso XXVIII, da Constituição confere um direito aos trabalhadores de ter realizado o seguro, público e privado, por seu empregador.

Esse seguro, todavia, não pode ser válvula de escape para o empregador desrespeitar as normas ambientais. A fim de garantir a prevenção ambiental, a ordem jurídica tem um mecanismo de defesa que é o direito regressivo conferido ao INSS e à seguradora, sozinha ou em conjunto com a União, de reaver os valores pagos em caso de dolo ou culpa do empregador.

Portanto, a culpa e o risco integram-se na responsabilidade civil dos acidentes do trabalho.

Palavras-chaves: normas jurídicas - saúde - meio ambiente do trabalho - acidente do trabalho - responsabilidade - culpa - risco - seguro - integração regresso - terceirização. 


\section{ABSTRACT}

The juridical order establishes health and work environment protection norms which impose obligations on employers and, at the same time, confer workers subjective rights to a healthy work environment.

Any failure in this protective net leads to work-related accident, which may be a sudden or gradual event that causes moral and patrimonial damages to the worker's health, once it is a result of his/her own professional activity.

Responsibility for these accidents evolved from criminal liability to nonconsideration and direction by risk. The unbalance created by these work-related accidents led the State to guarantee food benefits to mutilated workers through social security. However, due to insufficient payment by the state agency, the worker relies on his civil rights postulates to complement his/her indemnization for the suffered damages.

Currently, civil liability is based on the non-compliance with safety contract terms by the employer and the economic activity risk, considering that the employer that offers advantages must bear the onus.

Alongside with the State liability, employer's civil liability must be safeguarded by private insurance, since risk socialization is indispensable to maintain social peace. This mixed system of damages indemnization and State benefits agrees with the constitutional precept which determines that work-related accidents coverage is made, concurrently, by the social security as well as by the private sector.

In addition, article 7, subsection XXVIII, from the Constitution confers workers the right of insurance, public and private, by his/her employer.

This insurance, however, is not an excuse for employers to break environmental rules. To guarantee environmental protection, the juridical order has a defense mechanism which is the regressive right conferred to the INSS and the insurance company, alone or together with the Union, of getting back the values paid in case of employer's misconduct or guilt.

Thus, guilt and risk are integrated in work-related civil liability.

Key words: juridical norms - health - work environment - work-related accident -

$$
\text { liability - guilt - risk - insurance - integration - regression - outsourcing }
$$




\section{SUMÁRIO}

1. TUTELA JURÍDICA DA VIDA E DA SAÚDE DO TRABALHADOR ............................ 12

1.1. O conteúdo dos direitos do homem sob a perspectiva histórica ...................................................12

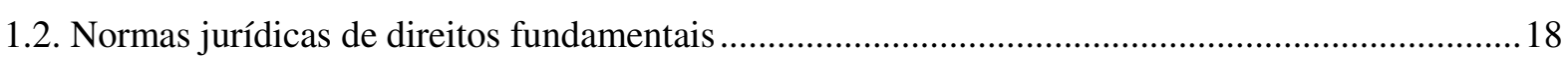

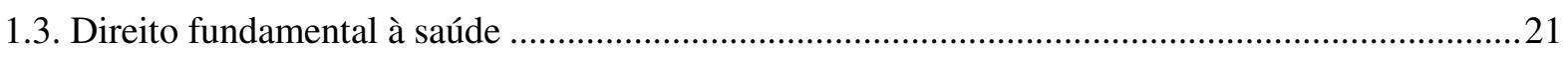

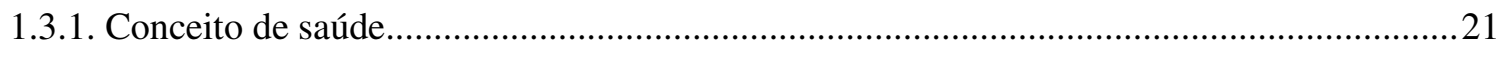

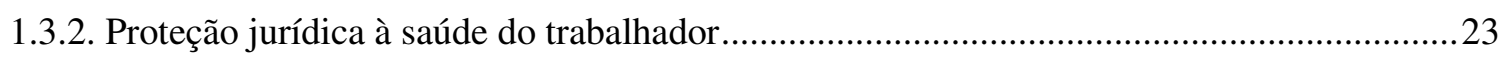

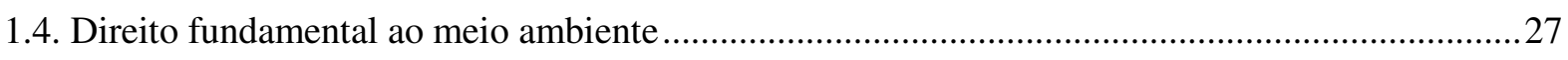

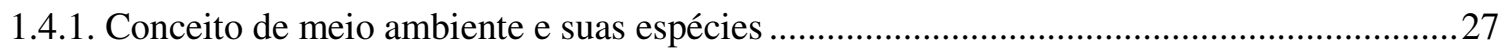

1.4.2. Proteção jurídica ao meio ambiente do trabalho ....................................................................... 29

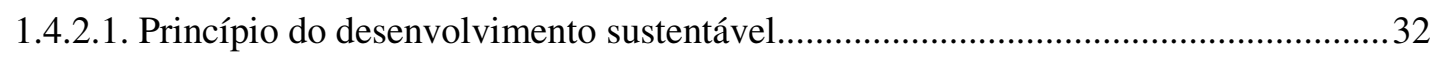

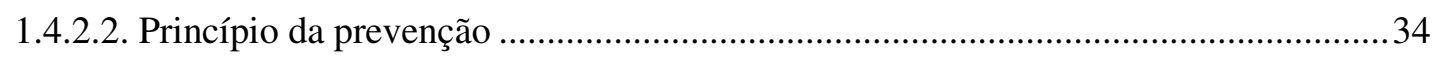

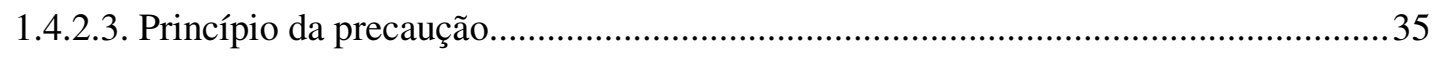

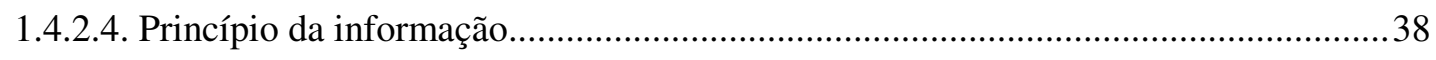

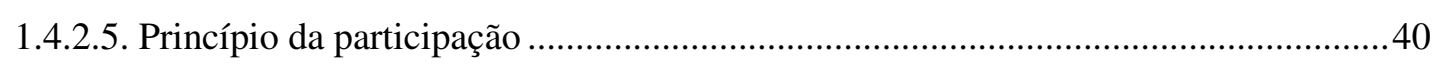

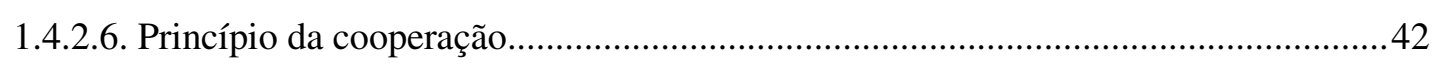

1.4.2.7. Princípios do poluidor-pagador e do ônus social.........................................................43

2. ACIDENTE DO TRABALHO E RESPONSABILIDADE ................................................45

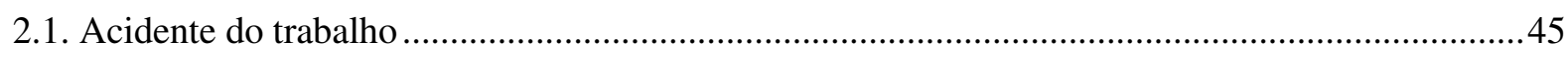

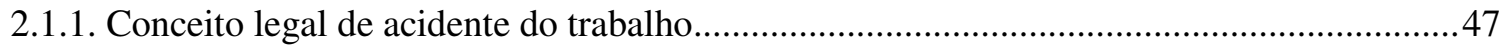

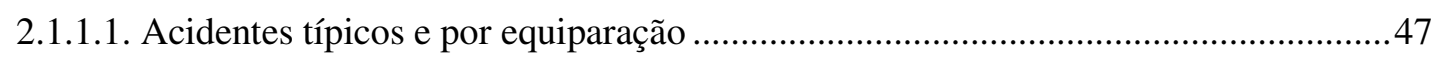

2.1.1.2. Doenças ocupacionais e o nexo técnico epidemiológico ...........................................50

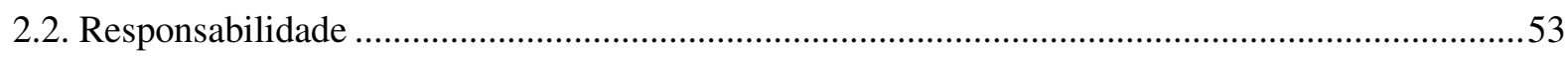

2.2.1. Evolução da responsabilidade e a influência no seguro social............................................53

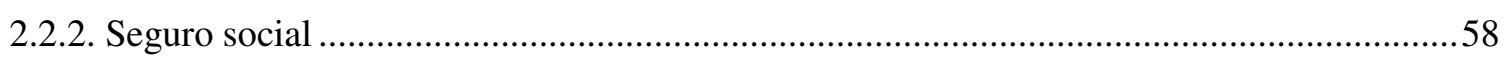

2.2.3. Seguro social e o acidente do trabalho no Brasil.................................................................63

2.2.3.1. Financiamento do seguro social para o acidente do trabalho ......................................66

2.2.3.2. Direito de regresso do Instituto Nacional do Seguro Social ......................................69

3. RESPONSABILIDADE CIVIL DO ACIDENTE DO TRABALHO ................................. 76

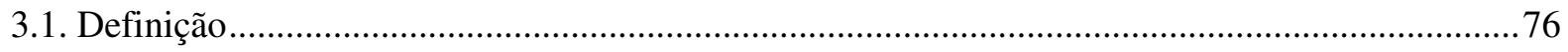

3.2. Modalidades de responsabilidade civil no direito brasileiro .........................................................77

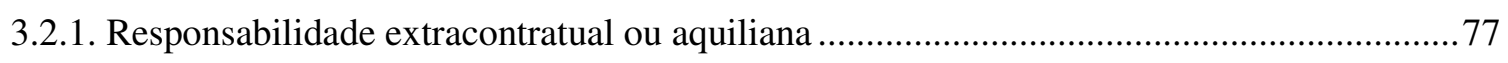

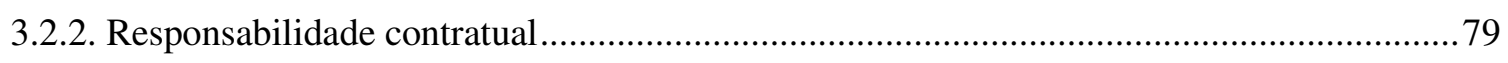




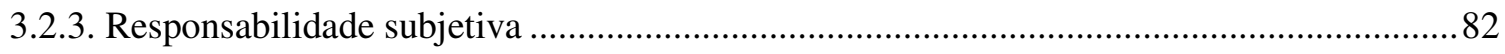

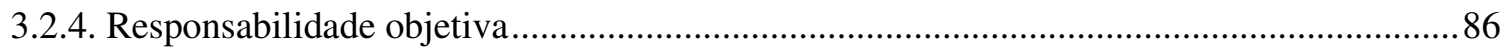

3.2.4.1. Responsabilidade objetiva alicerçada no meio ambiente ........................................ 87

3.2.4.2. Responsabilidade objetiva pelo risco da atividade .................................................91

3.2.4.3. Responsabilidade objetiva pelo risco da atividade na Consolidação das Leis do

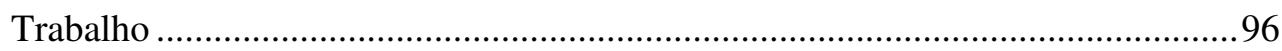

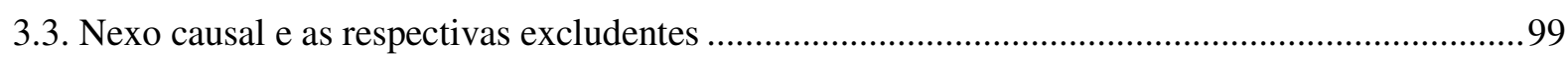

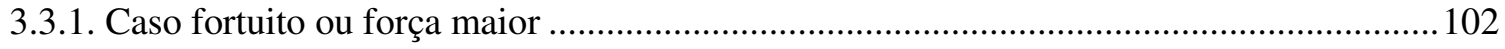

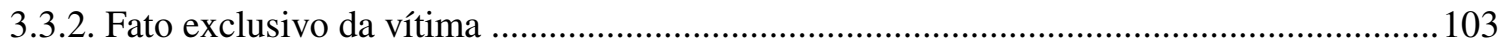

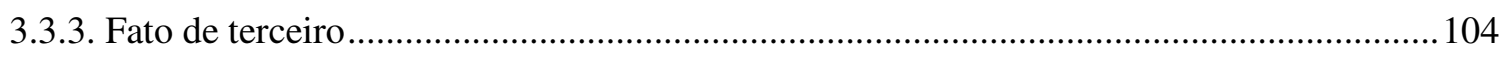

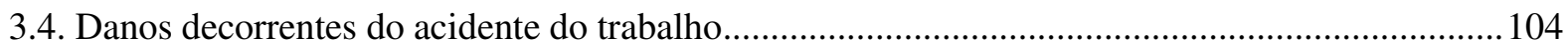

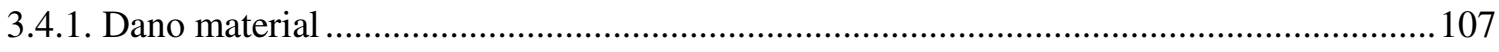

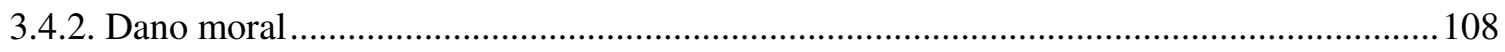

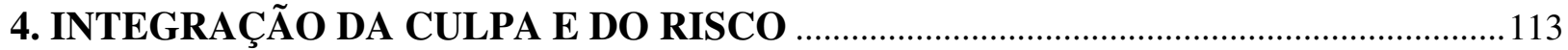

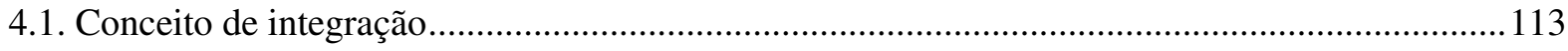

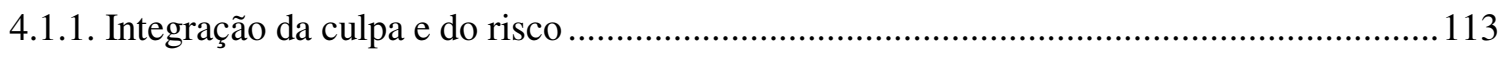

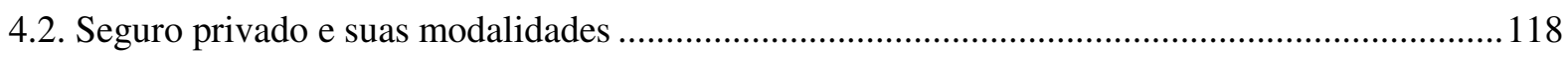

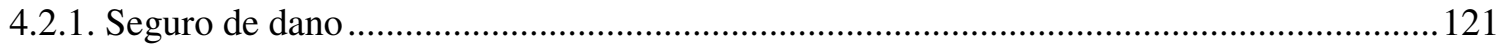

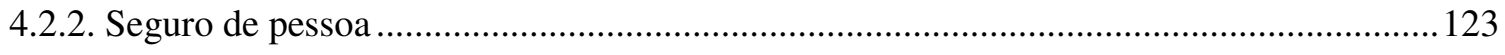

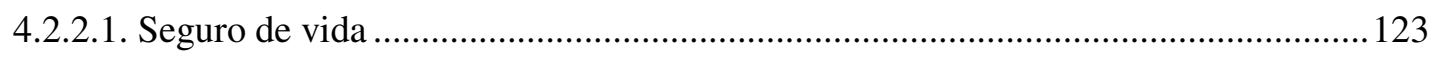

4.2.2.2. Seguro de acidente pessoal, uma proteção ao trabalhador........................................124

4.3. Mecanismos de integração da culpa e do risco ..........................................................................128

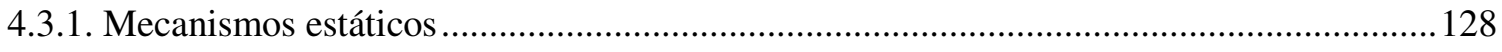

4.3.1.1. A natureza jurídica das seguradoras ..................................................................... 128

4.3.1.2. Cosseguro entre o setor privado e o setor público para os riscos

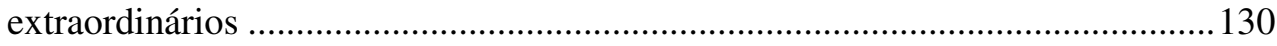

4.3.1.3. Limites da reparação dos danos pela seguradora................................................... 135

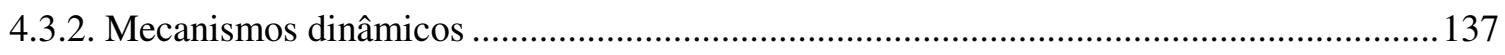

4.3.2.1. Exercício do direito de ação e a legitimidade ad causam .......................................137

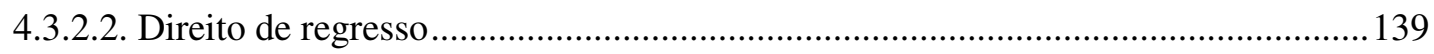

4.4. Terceirização e o seguro privado de acidente do trabalho ......................................................... 142

CONCLUSÕES

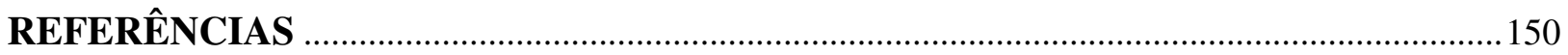




\section{INTRODUÇÃO}

Desde a Revolução Industrial, o aumento expressivo do número de acidentes do trabalho instigou estudos sobre a responsabilidade pelos danos deles decorrentes, pois uma força de trabalho mutilada representa queda dos índices de produtividade e de produção econômica, com o consequente desequilíbrio do meio social. No Brasil, durante o ano de 2011, a Previdência Social apontou 711.164 acidentes do trabalho ${ }^{1}$.

Então, propõe-se, nesta dissertação, demonstrar a integração da culpa e do risco na responsabilidade dos acidentes do trabalho, haja vista que sempre esses dois elementos nortearam a evolução do instituto.

O ponto de partida para as pesquisas foi o controvertido artigo $7^{\circ}$, inciso XXVIII, da Constituição Federal, que confere ao trabalhador um direito ao seguro a cargo de seu empregador, sem excluir a responsabilidade deste em caso de dolo ou culpa. Assim, o objetivo foi extrair o sentido desse direito social em harmonia com o sistema jurídico.

Para compreender o impacto do acidente do trabalho à pessoa do trabalhador e à sociedade, foi necessário voltar-se para a perspectiva histórica do conceito de pessoa e para os respectivos direitos que se consolidaram para a preservação da vida do obreiro, sobretudo, o direito à saúde e ao meio ambiente laboral equilibrado, uma vez que a inserção do homem no mercado de trabalho não transmuda a natureza humana.

Sendo notório que os acidentes do trabalho provocam desordens sociais nesse sistema de proteção, examinou-se quem seria o responsável para indenizar os prejuízos decorrentes dos infortúnios, sob uma evolução histórica. O estudo da teoria da responsabilidade revelou-se cheio de fragilidades, que se perpetuaram desde a origem no direito romano até no final do século XIX, uma vez que a culpa foi o elemento central para imputar as consequências do acidente. Mas os empregados não conseguiam provar esse estado anímico dos empregadores.

Devido à situação de injustiça, apontou-se a responsabilidade sem culpa dos empregadores, isto é, fundada no risco profissional. Essas indenizações, por sua vez,

\footnotetext{
${ }^{1}$ PREVIDÊNCIA SOCIAL. Anuário Estatístico da Previdência Social. Disponível em: <http://www.mpas.gov.br/conteudoDinamico.php?id=423>. Acesso em: 25 nov. 2012.
} 
precisavam de garantia que se estendesse além do patrimônio do empregador e, assim, chegou-se ao seguro social.

Observou-se, em nosso país, que a seguridade social concede benefícios previdenciários aos trabalhadores, que são acidentados no decorrer de seu labor e em outras situações correlatas, como os infortúnios eclodidos no percurso da casa ao trabalho e vice-versa. Apesar de uma cobertura ampla, verificou-se que os benefícios são limitados ao caráter alimentar e não abrangem todos os prejuízos sofridos por eles.

Por isso, foi preciso continuar o exame da responsabilidade civil do empregador a fim de garantir a completa indenização, tendo-se como premissa outro artigo constitucional que diz que a cobertura do risco de acidentes do trabalho será atendido pelo regime geral de previdência social e pelo setor privado.

Passou-se, então, pelas teorias da culpa e do risco, conforme o momento histórico. Mostrou-se o risco integral sobre os danos ao meio ambiente até aquele provocado pelo exercício normal de uma atividade, conforme previsão do artigo 927, parágrafo único do Código Civil. Todas as teorias, contudo, apresentavam deficiências no tocante ao amparo da vítima e não atendiam ao comando constitucional expresso do artigo $7^{\circ}$. Enquanto não se consegue provar a culpa, o risco não garante pagamento ao acidentado.

Assim, instigou-se a busca de uma solução que propiciasse aos trabalhadores a preservação da saúde no ambiente laboral e assegurasse a indenização se o infortúnio ocorresse. Para tal resposta, recorreu-se aos fundamentos do seguro social e sua trasladação para o seguro privado. Novamente, o simples negócio jurídico do seguro não foi idôneo para a defesa da vida do trabalhador.

Logo, a dissertação exibiu mecanismos estáticos e dinâmicos que levem garantia pecuniária e segurança ao empregado quanto à sua integridade física e psíquica, por meio da integração da culpa e do risco.

Finalmente, essa proposição para ser válida deve atender, ainda, as novas formas de prestação de serviços. Consequentemente, tratou-se de como essas regras de responsabilidade se aplicam à terceirização.

Todas as premissas postas foram solucionadas pelo método dialético, ou seja, analisou-se as posições doutrinárias em face de cada desafio encontrado e procurou-se dar uma resposta que buscasse coerência com todo o ordenamento jurídico, tendo a saúde e o 
meio ambiente do trabalho como fins a serem atingidos. As decisões judiciais proferidas pelos Tribunais só foram usadas para corroborar determinados entendimentos doutrinários.

Fixando-se a saúde e o meio ambiente do trabalho como os pontos norteadores do estudo, a construção dessa dissertação desenvolver-se-á da origem da responsabilidade do acidente do trabalho até o momento atual, com o escopo de comprovar que as etapas não são superadas, e sim integradas. 


\section{TUTELA JURÍDICA DA VIDA E DA SAÚDE DO TRABALHADOR}

\subsection{O conteúdo dos direitos do homem sob a perspectiva histórica}

Toda a tutela jurídica conferida ao trabalhador e a sua integridade física durante a prestação de serviços é decorrente de sua própria natureza humana. A busca dessa essência do ser humano remonta à Antiguidade clássica.

Inicialmente, o eixo central da história da humanidade deu-se no período axial, entre 600 e 480 antes de Cristo, em que nasceu a filosofia ocidental pela qual o saber focou-se na razão e o ser humano passou a ser considerado, em sua igualdade essencial, como ser dotado de liberdade e razão, apesar das múltiplas diferenças de sexo, de raça, de religião ou de costumes sociais.

No século V antes de Cristo, em Atenas, surgem, concomitantemente, a tragédia e a democracia. Todo o poder político superior foi suprimido e direcionado ao próprio povo. O fundamento dessa democracia foi o homem livre e dotado de individualidade ${ }^{2}$.

Por conseguinte, o questionamento dos mitos religiosos tradicionais foi abolido como critério supremo das ações humanas. Contrariamente, esse critério tornou-se o próprio homem. Por isso, a tragédia grega representou a grande introspecção nos subterrâneos da alma humana, povoados de paixões, de sentimentos e de emoções, de caráter irracional e incontrolável. O homem aparece em si mesmo como um problema, no sentido apresentado pelos geômetras gregos, ou seja, um obstáculo à compreensão, uma dificuldade proposta à razão humana ${ }^{3}$.

Ao lado dessa compreensão da igualdade dos seres humanos, conjuga-se uma instituição social de grande importância que é a lei escrita, como regra geral e uniforme aplicável a todos os indivíduos que vivem em sociedade organizada, e que passou a ser o fundamento da sociedade política na Grécia.

Paralelamente às leis escritas, as leis não escritas designavam o costume juridicamente relevante ou as leis universais, originalmente de cunho religioso, que não se

\footnotetext{
${ }^{2}$ SARLET, Ingo Wolfgang. A eficácia dos direitos fundamentais. 7. ed. Porto Alegre: Livr. do Advogado, 2007. p. 45.

${ }^{3}$ COMPARATO, Fábio Konder. A afirmação histórica dos direitos humanos. 2. ed. São Paulo: Saraiva, 2001. p. 9.
} 
prestavam a ser promulgadas no território de uma só nação e eram usadas com ênfase na sociedade antiga ${ }^{4}$. O fundamento religioso das leis não escritas foi paulatinamente dissipado e substituído pela natureza, de acordo com os sofistas ${ }^{5}$ e os estoicos ${ }^{6}$.

A igualdade essencial do ser humano também foi demonstrada por Sócrates, que afirmou que a essência do ser humano está na alma, não no corpo nem na união entre corpo e alma. A individualidade de cada ser humano não pode ser confundida com a aparência, estampada no rosto. Esse contraste entre a máscara teatral e a essência de cada ser humano foi aprofundada pelos estoicos. A unidade essencial do ser humano, distinta da aparência corporal, fez com que os estoicos utilizassem dois conceitos: hypostasis e prosopon. $\mathrm{O}$ termo hypostasis significa o substrato ou o suporte individual de algo, ao passo que prosopon é um papel que se representa. Dessa forma, o papel dramático que cada um de nós representa na vida não se confunde com a individualidade pessoal ${ }^{7}$.

Após a elaboração do conceito de pessoa na Idade Antiga, Boécio traz influências para a Idade Média ao expor seu conceito de pessoa nos seguintes termos: diz-se propriamente pessoa a substância individual da natureza racional ${ }^{8}$.

Dessa forma, Santo Tomás de Aquino retomou a concepção cristã de igualdade dos homens perante Deus, bem como a existência de duas ordens distintas, sendo uma formada pelo direito natural e a outra pelo direito positivo ${ }^{9}$. Essa igualdade essencial da pessoa, que forma a base do conceito universal de direitos humanos, foi fundamento para que tanto os escolásticos e como os canonistas concluíssem que as leis contrárias ao direito natural não teriam vigência ou força jurídica.

\footnotetext{
${ }^{4} \mathrm{O}$ recurso às leis não escritas e fundadas em cunho religioso foi exteriorizado na peça Antígona, de Sófocles. A proibição de se enterrarem cadáveres dos cidadãos que se revoltaram contra o governo e que foram condenados com a pena de morte foi questionada por Antígona diante do tirano Creonte, pois o irmão dela estava impedido de ser enterrado. Então, Antígona diz que essa lei impeditiva dos funerais não foi promulgada por Zeus e que Creonte não tinha força para impor aos mortais até a obrigação de transgredir normas divinas, não escritas, inevitáveis; não é de hoje, não é de ontem, é desde os tempos mais remotos que elas vigem, sem que ninguém possa dizer quando surgiram. SÓFOCLES. A Triologia Tebana. Édipo Rei, Édipo em Colono e Antígona. Trad. Mário da Gama Kury. 10. ed. Rio de Janeiro: Jorge Zahar, 2002. p. 219.

${ }^{5} \mathrm{~A}$ sofística é uma corrente filosófica que influenciou os intelectuais gregos dos séculos V e VI antes de Cristo. Os sofistas concentraram seu foco no homem e em seus problemas. ABBAGNANO, Nicola. Dicionário de filosofia. 2. ed. São Paulo: Martins Fontes, 1998. p. 918.

${ }^{6} \mathrm{O}$ estoicismo é uma das grandes correntes filosóficas do período helenista fundada por volta de 300 antes de Cristo, por Zenão de Cício. Um dos fundamentos do ensinamento estoico é que o homem é guiado infalivelmente pela razão, e essa razão lhe fornece normas infalíveis de ação que constituem o direito natural. Outrossim, os estoicos aduziram o cosmopolitismo, isto é, a doutrina de que o homem não é cidadão de um país, mas do mundo. ABBAGNANO, Nicola. op. cit., p. 375.
}

${ }^{7}$ COMPARATO, Fábio Konder. op. cit., p. 16.

${ }^{8}$ Id. Ibid., p. 19.

${ }^{9}$ SARLET, Ingo Wolfgang. op. cit., p. 46. 
Assim, as normas positivas, eclesiásticas ou seculares, contrárias ao direito natural, deveriam ser excluídas. Paulatinamente, o direito natural deixa de ter fundamento divino e torna-se laico. O reconhecimento de direitos às pessoas fundamenta-se na liberdade e na dignidade.

A terceira fase da elaboração teórica do conceito de pessoa, como sujeito de direitos universais, adveio com Kant. O primeiro axioma ético de Kant é de que o ser racional possui a capacidade de agir conforme a representação de regras ou de princípios, pois só um ser racional tem vontade, que é uma espécie de razão, denominada de razão prática $^{10}$.

Para esse filósofo, existem dois tipos de imperativos, a saber: os hipotéticos e os categóricos. Enquanto os imperativos hipotéticos representam a necessidade prática de ação possível, considerada como meio de se conseguir algo desejado, os categóricos significam uma ação necessária em si mesma, sem relação com finalidade nenhuma exterior a ela.

Dessa forma, o ser humano existe como um fim em si mesmo e, com efeito, tem uma dignidade e não, um preço como as coisas. A pessoa, ao mesmo tempo em que se submete às leis da razão prática, é fonte dessas mesmas leis, de âmbito universal. Por isso, para Kant, a regra de conduta é dada pela razão prática e o propósito é apenas fazer ou deixar de fazer ${ }^{11}$.

Dentro desse universo de ideias sobre o conceito de pessoa, as declarações de direitos do homem consistiram, inicialmente, apenas em teorias filosóficas.

O jusnaturalismo moderno trouxe o postulado de que o homem, por sua natureza, tem direitos que não podem ser alienados e que nem o Estado pode lhe subtrair. Segundo Locke, o verdadeiro estado do homem é o natural em que todos os homens são livres e iguais e, em contrapartida, o estado civil é uma criação artificial que permite a explicitação da liberdade e da igualdade naturais. Todavia, essa fase era desprovida de eficácia, pois consistia apenas de uma proposta para o futuro legislador ${ }^{12}$.

\footnotetext{
${ }^{10}$ COMPARATO, Fábio Konder. op. cit., p. 20.

${ }^{11}$ KANT, Immanuel. Crítica da razão pura. Trad. Manuela Pinto dos Santos; Morujão, Alexandre Fradique. 4. ed. Lisboa: Fundação Calouste Gulbenkian, 1997. p. 638.

${ }^{12}$ BOBBIO, Norberto. A era dos direitos. Trad. Carlos Nelson Coutinho. 10. ed. Rio de Janeiro: Campus, 1992. p. 29.
} 
Gradativamente, diversos direitos foram reconhecidos pelos ordenamentos jurídicos de cada país, que os positivou nos textos constitucionais e, em segundo momento, esses direitos foram também chancelados internacionalmente ${ }^{13}$.

Esse arcabouço teórico culminou na concretização do Estado de Direito, na sua acepção liberal-burguesa, que caracterizou os direitos fundamentais de primeira dimensão. O documento estatal que marcou os direitos fundamentais constitucionais foi a Declaração de Direitos do Povo da Virgínia, de 1776, que teve sua eficácia reconhecida inclusive à representação popular, vinculando todos os poderes públicos ${ }^{14}$. Outro diploma que se destacou no período foi a Declaração Francesa dos Direitos do Homem e do Cidadão de 1789. Dessa forma, esses direitos têm um cunho individualista, que são uma zona de demarcação para a não intervenção do Estado. Os clássicos direitos nesse momento são: a vida, a liberdade, a igualdade e a propriedade.

O pensamento filosófico contemporâneo caminhou no sentido de que o ser humano é um vir a ser, um contínuo devir, pelas seguintes razões: a personalidade de cada ser humano é moldada por todo o peso do passado e que o tempo é irreversível na natureza. Assim, a personalidade de cada indivíduo é algo incompleto e inacabado, uma realidade em contínua transformação. Como corolário lógico, os direitos reconhecidos no decorrer da História são caracterizados por complementariedade, e não substituição. Por isso, prefere-se a terminologia dimensões de direitos a gerações ${ }^{15}$.

O tratamento da humanidade como um fim em si mesmo implica, além do dever negativo em não prejudicar ninguém, no dever de favorecer o fim de outrem. Isso trouxe reflexos na ordem jurídica ao estabelecer que aos direitos de liberdade individuais adicionam-se os direitos que exijam realização de políticas públicas de conteúdo econômico e social por parte do Estado ${ }^{16}$. Os desprivilegiados reivindicaram um direito de

\footnotetext{
${ }^{13}$ É consagrado no direito nacional por Ingo Wolfgang Sarlet que o critério diferenciador das diversas nomenclaturas desses direitos é a positivação deles por um dado Estado que, consequentemente, reflete na maior eficácia jurídica e social desses direitos. Assim, a expressão direitos humanos é empregada no direito internacional, enquanto nas constituições dos países prefere-se a direitos fundamentais. SARLET, Ingo Wolfgang. op. cit., p. 36-40. Em Portugal, Canotilho distingue entre direitos do homem que são válidos para todos os povos em todos os tempos e direitos fundamentais que são direitos do homem garantidos e limitados espacio-temporalmente. CANOTILHO, José Joaquim Gomes. Direito constitucional e teoria da Constituição. 7. ed. Coimbra: Almedina, 2007. p. 393.

${ }^{14}$ SARLET, Ingo Wolfgang. op. cit., p. 51-52.

${ }^{15}$ Id. Ibid., p. 54. Impende ressaltar que a expressão "dimensões de direitos” é criticada por Arion S. Romita, sob o fundamento de que "dimensões" refere-se a um significado e uma função distinta do mesmo direito, e não um grupo de direitos. Por isso, prefere utilizar "naipes" ou "famílias" de direitos fundamentais. ROMITA. Arion Sayão. Direitos fundamentais nas relações de trabalho. São Paulo: LTr, 2005. p. 89-90.

${ }^{16}$ COMPARATO, Fábio Konder. op. cit., p. 24.
} 
participar do "bem-estar social" que, segundo Celso Lafer, é o conjunto de bens que os homens acumulam no tempo ${ }^{17}$.

Norberto Bobbio obtempera que o nascimento e o crescimento dos direitos sociais é diretamente proporcional à transformação da sociedade, pois é essa modificação social que faz surgir novas exigências, imprevisíveis e, até então, inexequíveis. Ressalta, também, que as exigências que se concretizam a partir de uma intervenção pública ou de prestação de serviços públicos do Estado dependem do nível de desenvolvimento econômico e tecnológico ${ }^{18}$.

Algumas exigências econômicas e sociais foram reconhecidas pela Constituição francesa de 1848. Contudo, a plena afirmação deu-se com a Constituição mexicana de 1917 e com a de Weimar de 1919. Dentre os direitos sociais de segunda dimensão, podemse citar: o direito à saúde, ao trabalho, à educação.

Em seguida, com a descoberta do mundo dos valores, abre-se a quarta fase histórica na elaboração do conceito de pessoa. O homem é o único ser vivo que dirige a sua vida em função de preferências valorativas, isto é, o legislador universal em função dos valores éticos que aprecia e que se submete voluntariamente a tais leis. Após a consolidação dos direitos na titularidade do homem, pode-se inferir que os valores almejados pela pessoa são a fraternidade e a solidariedade que, por sua vez, consubstanciam-se nos direitos de terceira dimensão, cuja destinação é a proteção dos grupos, caracterizados por titularidade coletiva ou difusa. $\mathrm{O}$ valor supremo é o gênero humano, em sua existencialidade concreta. Nessa seara, assumem relevância, o direito à paz, ao meio ambiente e à qualidade de vida ${ }^{19}$.

Na efetividade desses direitos, às vezes, não existe coincidência entre a hierarquia de valores prevalecente no meio social e as normas editadas pelo Estado e, por isso, a solução será dada pela ponderação de valores em função das circunstâncias do caso concreto.

Em razão dessa possibilidade de ponderação entre os direitos, infere-se que eles possuem vários fundamentos possíveis, e não um fundamento absoluto. Além de ser frágil o alicerce na natureza humana, a classe de direitos do homem é heterogênea entre as diversas culturas e períodos históricos, haja vista que soluções distintas para o mesmo caso

\footnotetext{
${ }^{17}$ LAFER, Celso. A reconstrução histórica dos direitos humanos. São Paulo: Companhia das Letras, 2001. p. 127.

${ }^{18}$ BOBBIO, Norberto. op. cit., p. 76.

${ }^{19}$ SARLET, Ingo Wolfgang. op. cit., p. 58-59.
} 
podem ser todas compatíveis com a natureza humana. Norberto Bobbio cita o exemplo do direito à sucessão dos bens, que pode ter três soluções razoáveis: a) transmissão dos bens para a comunidade; b) transferência para a família e c) livre disposição dos bens ${ }^{20}$.

Apesar da consagração dos direitos nos textos normativos de cada país, a universalização de fato dos direitos humanos deu-se por meio da Declaração Universal dos Direitos do Homem, de 1948, haja vista que o consenso sobre sua validade e sua capacidade para reger os destinos da comunidade futura de todos os homens foi explicitamente declarado ${ }^{21}$. Essa declaração também foi o marco para a afirmação dos direitos de modo universal e positivo, uma vez que não é apenas teórica como no jusnaturalismo, nem limitada aos homens de determinado Estado como as Declarações americana e francesa.

Por fim, a última etapa na elaboração do conceito de pessoa iniciou-se no século $\mathrm{XX}$, com o existencialismo. $\mathrm{O}$ foco foi a realidade relacional da vida, implicada no interrelacionamento entre sujeito-objeto, revelado pela teoria axiológica. A realidade é a pessoa imersa em suas circunstâncias, entendidas como aquilo que impregna a vida.

Pode-se construir um paralelo entre esse estágio do conceito de pessoa com a quarta dimensão de direitos do homem, na visão preconizada, no direito pátrio, por Paulo Bonavides. Segundo esse autor, os direitos de quarta dimensão são: direito à democracia direta, direito à informação e direito ao pluralismo ${ }^{22}$. A institucionalização do Estado Social concretiza-se com a globalização política que é atingida pela democracia direta. Essa democracia direta é materialmente possível pelos avanços da tecnologia da comunicação e legitimamente sustentáveis pela informação correta e pelas aberturas pluralistas $^{23}$. Assim, as condições em que a pessoa está inserida serão determinantes aos seus interesses que, por sua vez, serão manifestados pela democracia direta.

\footnotetext{
${ }^{20}$ BOBBIO, Norberto. op. cit., p. 15-24.

${ }^{21}$ Id. Ibid., p. 28.

${ }^{22}$ Cumpre noticiar que Norberto Bobbio refere-se aos direitos de quarta dimensão aqueles ligados à engenharia genética, cujos efeitos da pesquisa biológica podem ser catastróficos para a humanidade. Todavia, ele diz que essa aspiração de não ter manipulado o patrimônio genético não é desfrutado integralmente. BOBBIO, Norberto. op. cit., p. 6-10. Em contrapartida, Ingo Wolfgang Sarlet nega a existência de uma quarta dimensão de direitos. SARLET, Ingo Wolfgang. op. cit., p. 60. Nesse sentido também: FERREIRA FILHO, Manoel Gonçalves. Direitos humanos fundamentais. 3. ed. São Paulo: Saraiva, 1999, p. 6; MORAES, Alexandre. Direito constitucional. 17. ed. São Paulo: Atlas, 2005. p. 27.

${ }^{23}$ BONAVIDES, Paulo. Curso de direito constitucional. 12. ed. São Paulo: Malheiros Ed., 2002. p. 524-526.
} 
Portanto, direitos do homem é o conjunto mínimo de direitos necessários para assegurar-lhe uma vida fundada em liberdade e em dignidade ${ }^{24}$. Todos são direitos que decorrem da dignidade e que estabelecem aquilo que os homens, os grupos sociais e os povos devem poder exigir, sob a forma de omissões, ações, formas de participação e prestações àqueles que detêm o poder no Estado, nas oligarquias econômicas e na comunidade internacional $^{25}$.

A efetividade desses direitos do homem depende do grau de positivação nas ordens internas dos países e os respectivos mecanismos de exigi-los, bem como sua regulação na esfera internacional.

\subsection{Normas jurídicas de direitos fundamentais}

Os direitos fundamentais são veiculados por normas jurídicas positivadas nas Constituições dos respectivos Estados. Inicialmente, cumpre distinguir normas de enunciados normativos. Ao mesmo tempo em que os enunciados normativos são o conjunto de signos, eles também expressam as normas. Dessa forma, as normas jurídicas são o significado dos enunciados normativos que, por sua vez, exprimem algo que deve $\operatorname{ser}^{26}$.

A estrutura normativa é representada por uma situação objetiva, hipotética à qual estão ligadas certas consequências práticas, ou seja, os efeitos por ela prescritos. Dessa forma, a norma jurídica prescreve os resultados enunciados na estatuição ou na injunção em relação ao fato objetivo que pode se concretizar ${ }^{27}$.

Como é cediço, ao lado das normas de conduta, tem-se as normas organizacionais. Por isso, Miguel Reale diz que norma jurídica é uma estrutura propositalmente enunciativa de uma forma de organização ou de conduta que deve ser seguida de modo objetivo e obrigatório $^{28}$. A obrigatoriedade retira a identificação do agente emissor, bem como dos destinatários.

\footnotetext{
${ }^{24}$ RAMOS, André de Carvalho. Direitos humanos em juízo. São Paulo: Max Limonad, 2001. p. 27.

${ }^{25}$ CAUPERS, João. Os direitos fundamentais dos trabalhadores e a Constituição. Lisboa: Almedina, 1985. p. 18.

${ }^{26}$ ALEXY, Robert. Teoria dos direitos fundamentais. Trad. Virgílio Afonso da Silva. São Paulo: Malheiros Ed., 2008. p. 58.

${ }^{27}$ GRAU, Eros Roberto. Ensaio e discurso sobre interpretação/aplicação do direito. São Paulo: Malheiros Ed., 2002. p. 143.

${ }^{28}$ REALE, Miguel. Lições preliminaries de direito. 24. ed. São Paulo: Saraiva, 1999. p. 95.
} 
Dessa forma, Tércio Sampaio Ferraz Júnior afirma que norma é um comando despsicologizado, isto é, um comando que a figura do emissor perde importância e o destinatário não é identificado, haja vista que as normas jurídicas são comandos genéricos e universais ${ }^{29}$.

Por essa razão, Hans Kelsen procura o fundamento de validade de uma norma em outra de nível superior até atingir a mais elevada, que tem de ser pressuposta, uma vez que não pode ser posta por uma autoridade, cuja competência teria de se fundar em uma norma mais elevada. Ele denomina a norma pressuposta de norma fundamental ${ }^{30}$.

As normas de direitos fundamentais incluem, além daquelas estabelecidas diretamente do texto da Constituição, as que lhe são decorrentes. O cerne do problema consiste em definir o critério para a atribuição da norma de direito fundamental. Segundo Robert Alexy, uma norma jurídica será de direito fundamental se for possível estabelecer uma correta fundamentação a direitos fundamentais ${ }^{31}$.

Essas normas jurídicas podem ser estruturadas por regras e pelos princípios ${ }^{32}$.

Para Robert Alexy, os princípios são normas que ordenam que algo seja realizado na maior medida do possível dentro das possibilidades jurídicas e fáticas existentes. Logo, os princípios são mandamentos de otimização. Ao contrário, as regras são normas que são sempre satisfeitas ou não satisfeitas e contêm determinações daquilo que é fática e juridicamente possível ${ }^{33}$.

Como consequência, o conflito de regras é resolvido se uma cláusula de exceção é introduzida em uma das regras ou se uma delas é invalidada. Em contrapartida, a colisão entre princípios leva a precedência de um princípio em face do outro, sob determinadas condições. Faz-se, então, um sopesamento entre os interesses conflitantes com base no caso concreto.

Para Ronald Dworkin, princípio é um padrão que deve ser seguido, não para assegurar uma situação econômica, política ou social, mas sim, para atender a uma

\footnotetext{
${ }^{29}$ FERRAZ JÚNIOR, Tércio Sampaio. Introdução ao estudo do direito: técnica, decisão, dominação. 2. ed. São Paulo: Atlas, 1994. p. 118-119.

${ }^{30}$ KELSEN, Hans. Teoria pura do direito. 6. ed. São Paulo: Martins Fontes, 1998. p. 215-217.

${ }^{31}$ ALEXY, Robert. op. cit., p. 73-74.

${ }^{32}$ Cf. CANOTILHO, José Joaquim Gomes. op. cit., p. 1159 e ss; GRAU, Eros Roberto. op. cit., p. 122 e ss; SILVA, José Afonso da. Curso de direito constitucional positivo. 8. ed. São Paulo: Malheiros Ed., 1992. p. 91 e ss; BONAVIDES, Paulo. op. cit., p. 243 e ss; ALEXY, Robert. op. cit., p. 85 e ss.

${ }^{33}$ ALEXY, Robert. op. cit., p. 90-91.
} 
exigência de justiça, de equidade ou até outra dimensão moral ${ }^{34}$. Dessa forma, os princípios têm peso ou importância que são considerados no momento de resolver a colisão. Todavia, as regras também são padrões de comportamento a serem seguidos que, no entender desse doutrinador, são aplicáveis à maneira do tudo-ou-nada ${ }^{35}$. Assim, todas as exceções devem ser arroladas nos enunciados das regras e eventual conflito de regras será solucionado pela validade de uma e a invalidade de outra. O elemento norteador de validade da regra é expresso em outra regra que confere a procedência pelos critérios da hierarquia, especialidade e temporalidade.

José Joaquim Gomes Canotilho diz que princípios são normas jurídicas impositivas de uma otimização com variantes de sua concretização, conforme as condicionantes fáticas e jurídicas, ao passo que regras são normas que prescrevem uma exigência que é ou não cumprida. Como corolário, para esse doutrinador português, os princípios são objeto de ponderação e harmonização, pois eles contêm apenas exigências ou standards, ao contrário das regras, que são fixações normativas definitivas que inviabilizam a validade simultânea de regras conflitantes ${ }^{36}$.

Eros Roberto Grau acrescenta, na distinção entre regras e princípios, o fato de atuarem como mecanismo de controle da produção de regras, haja vista que estes podem ser a medida do controle externo da produção de normas. Outrossim, Eros Grau aduz que o intérprete escolherá o princípio a partir do conteúdo do próprio princípio, ao passo que a regra será validada diante de critérios formais, exteriores a ela ${ }^{37}$.

Feitas essas considerações, sabe-se que, na relação de trabalho, o empregado é um ser humano apto a receber e exigir direitos independentemente de sua condição de ser subordinado juridicamente. Além do direito social do trabalho, que é típico da relação de emprego, a saúde e o meio ambiente em que está inserido constituem direitos fundamentais para se evitar os acidentes do trabalho. Ver-se-á, a seguir, como esses direitos manifestamse em normas jurídicas.

\footnotetext{
${ }^{34}$ DWORKIN, Ronald. Levando os direitos a sério. Trad. Jefferson Luiz Camargo. São Paulo: Martins Fontes, 2007. p. 40 e ss.

${ }^{35}$ Eros Roberto Grau apresenta crítica a esse conceito de Ronald Dworkin ao compreender que as regras comportam exceções ao verificar que na colisão de princípios, o afastamento de um deles em favor do outro importa em perda de efetividade das regras que àquele dão concretude. Ademais, esse autor sustenta que as regras também podem se manifestar em sua dimensão de peso. GRAU, Eros Roberto. op. cit., p. 157.

${ }^{36}$ CANOTILHO, José Joaquim Gomes. op. cit., p. 1162.

${ }^{37}$ GRAU, Eros Roberto. op. cit., p. 167.
} 


\subsection{Direito fundamental à saúde}

\subsubsection{Conceito de saúde}

A Constituição da Organização Mundial da Saúde (OMS), de 7 de abril de 1948, trouxe em seu preâmbulo os contornos do conteúdo da saúde nos seguintes termos: "Saúde é o estado de completo bem-estar físico, mental e social de uma pessoa e não apenas ausência de doença ou enfermidade". Esse preâmbulo fixou a ideia de saúde como um bem coletivo, o que pode ser corroborado pelos seguintes princípios: a saúde de todos é fundamental para se alcançar a paz e a segurança e depende da mais ampla cooperação de indivíduos e Estados; os resultados alcançados por qualquer Estado na promoção e proteção da saúde são valiosos para todos, e a desigualdade dos diferentes países na promoção da saúde e no controle das doenças, especialmente as transmissíveis, constitui um perigo comum ${ }^{38}$.

Então, o bem-estar das pessoas pressupõe, além da dimensão individual, uma perspectiva coletiva que, por seu turno, implica no reconhecimento de deveres, tanto por parte do Estado como das outras pessoas. A própria Lei 8080/90, em seu artigo $3^{\circ}$, estabelece que a saúde tem como fatores condicionantes, entre outros, a alimentação, a moradia, o saneamento básico, o meio ambiente, o trabalho, a renda, a educação, o transporte, o lazer e o acesso aos bens e serviços essenciais. Então, os níveis de saúde da população expressam a organização social e econômica do país.

Outrossim, é possível inferir-se do preâmbulo da Constituição da OMS que a saúde é um bem jurídico de desenvolvimento, com a necessidade de preservação presente e futura do indivíduo e de toda a humanidade.

Considerando os múltiplos aspectos que gravitam em torno da saúde, Sueli Gandolfi Dallari e Vidal Serrano Nunes Júnior a conceituam como o bem jurídico fundamental que, por meio da integração dinâmica de fatores individuais, coletivos e de

\footnotetext{
${ }^{38}$ ORGANIZAÇÃO MUNDIAL DA SAÚDE. Constituição da Organização Mundial da Saúde. Disponível em: <http://www.onu.org.br/a-onu-em-acao/a-onu-e-a-saude>. Acesso em: 29 out. 2012.
} 
desenvolvimento, visa a assegurar ao indivíduo o estado de completo bem-estar físico, psíquico e social $^{39}$.

Sob o enfoque trabalhista, a Convenção 155 da Organização Internacional do Trabalho diz que "saúde, com relação ao trabalho, abrange não só a falta de afecções e doenças, mas também os elementos físicos e mentais que atingem a saúde e estão diretamente relacionados com a segurança e a higiene do trabalho ${ }^{40,}$.

Dessa forma, saúde do trabalhador é uma espécie do gênero saúde que demanda a interação entre os fatores ocupacionais. Por isso, Bernardino Ramazzini, pai da Medicina do Trabalho, diz que o médico, ao visitar um doente, deve se informar de muita coisa a seu respeito, pelo próprio ou por seus acompanhantes, que foram já anunciadas por Hipócrates, a saber: o que o doente sente, qual a causa, desde quantos dias, se seu ventre funciona e que alimento ingeriu. Então, Ramazzini acrescenta a seguinte indagação: a que arte exerce? Por meio dessa pergunta é possível chegar às causas ocasionais do mal e, por conseguinte, atingir-se-ia uma cura mais feliz ${ }^{41}$.

Então, a saúde ocupacional é saúde pública dirigida a uma comunidade de trabalhadores e, como tal, deveria estar incluída no sistema de saúde e integrada à estrutura, aos programas e às agências de saúde pública ${ }^{42}$. Os objetivos da saúde ocupacional são: a promoção e a manutenção do mais alto grau de bem-estar físico, mental e social dos trabalhadores em todas as ocupações; a prevenção entre os trabalhadores de desvios de saúde causados pelas condições de trabalho; a proteção dos trabalhadores em seus empregos dos riscos resultantes de fatores adversos à saúde; a colocação e a manutenção do trabalhador adaptadas às condições fisiológicas e psicológicas. Em suma: a adaptação do trabalho ao homem e de cada homem a sua atividade ${ }^{43}$.

A ciência jurídica, atenta aos fatos sociais, capta esse conceito de saúde e procura atribuir valores específicos de uma sociedade em dado momento histórico, uma vez que a saúde depende não somente de fatores individuais, mas também da integração de fatores sociais e de desenvolvimento. Dessa forma, o efeito irradiador será a proliferação de normas jurídicas para tutelar o assunto.

\footnotetext{
${ }^{39}$ DALLARI, Sueli Gandolfi; NUNES JÚNIOR, Vidal Serrano. Direito sanitário. São Paulo: Ed. Verbatim, 2010. p. 13.

${ }^{40}$ ORGANIZAÇÃO INTERNACIONAL DO TRABALHO. Convenção 155 . Disponível em: <http://www.institutoamp.com.br/oit155.htm>. Acesso em: 21 abr. 2011.

${ }^{41}$ RAMAZZINI, Bernardino. De morbis artificum diatriba. Chicago: University of Chicago Press, 1940. p. 17.

${ }^{42}$ MENDES, René. Medicina do trabalho e doenças profissionais. São Paulo: Sarvier, 1980. p. 18.

${ }^{43}$ Id. Ibid., p. 11-12.
} 


\subsubsection{Proteção jurídica à saúde do trabalhador}

A saúde é considerada como um direito fundamental do trabalhador. Todavia, esse reconhecimento só foi atingido no século XIX com a Revolução Industrial. As primeiras leis sobre saúde do trabalhador foram editadas na Inglaterra.

Em 1830, um proprietário de uma fábrica inglesa incomodado com as péssimas condições de trabalho das crianças trabalhadoras procurou Robert Baker, médico inglês, para que este o aconselhasse quanto a melhor maneira de proteger a saúde das crianças.

Em resposta, Baker aconselhou-o a contratar um médico da localidade em que funcionava a fábrica para visitar, diariamente, o local de trabalho e estudar a sua possível influência sobre a saúde dos pequenos operários, que deveriam ser afastados de suas atividades profissionais tão logo fosse notado que estas estivessem prejudicando a sua saúde. Essa foi a origem do serviço médico industrial de todo o mundo.

A iniciativa desse empregador mostrou a necessidade que urgia de medidas de proteção ao trabalhador e, dessa maneira, uma comissão parlamentar de inquérito elaborou um cuidadoso relatório que concluiu que os legisladores se omitiram na tentativa de estabelecer regras que assegurassem o mínimo de condições de trabalho aos mais oprimidos da relação de emprego.

O impacto desse relatório fez a edição da lei inglesa (Factory Act), de 1833, que foi o marco da regulamentação no campo de proteção ao trabalhador, pois ela estabeleceu os limites de jornada de trabalho para menores de 18 anos, fixou a idade mínima no trabalho em 9 anos, determinou a obrigatoriedade de escolas nas fábricas, que deveriam ser frequentadas por menores de 13 anos, e um médico deveria atestar que o desenvolvimento físico da criança correspondia a sua idade cronológica ${ }^{44}$.

A Carta Encíclica Rerum Novarum foi editada, em 1891, por Leão XIII e trouxe alguns parâmetros para as condições de trabalho dos operários, sobretudo, a duração do labor $^{45}$.

\footnotetext{
${ }^{44}$ MENDES, René. op. cit., p. 7-8.

${ }^{45} \mathrm{O}$ capítulo 25 revela a proteção do trabalho dos operários, das mulheres e das crianças e prescreve, in verbis: "No que diz respeito aos bens naturais e exteriores, primeiro que tudo é um dever da autoridade pública subtrair o pobre operário à desumanidade de ávidos especuladores, que abusam, sem nenhuma descrição, tanto das pessoas como das coisas. Não é justo nem humano exigir do homem tanto trabalho a ponto de fazer pelo excesso da fadiga embrutecer o espírito e enfraquecer o corpo. A actividade do homem,
} 
Apesar do avanço de algumas leis, na primeira etapa de proteção à saúde do trabalhador, a preocupação restringia-se pela inserção apenas do profissional médico no ambiente laboral, que buscava apenas o atendimento do trabalhador doente sem influenciar ou mesmo analisar os fatores etiológicos ocupacionais da enfermidade, isto é, não se buscava relação com o trabalho desenvolvido. O médico do trabalho era um profissional de confiança do empregador, que tinha a obrigação apenas de curar o trabalhador para permitir o retorno à linha de produção. A Recomendação 97 da Organização Internacional do Trabalho (OIT) sobre a proteção à saúde dos trabalhadores instava os Estados-membros a incentivar a formação de médicos do trabalho.

A segunda etapa evolutiva deu-se com a Declaração Universal dos Direitos do Homem que, com seus princípios, permitiu o ingresso de outros profissionais especializados no diagnóstico e na prevenção de doenças e acidentes, com uma avaliação multidisciplinar do ambiente do trabalho. Nessa seara, a Recomendação 112 da OIT previu a criação de serviços de Medicina do Trabalho, ou seja, serviços nos locais de prestação do trabalho com vistas a assegurar a proteção do trabalhador de todo o risco que possa prejudicar sua saúde e que decorra do seu trabalho ou das condições em que ele é exercido; contribuir à adaptação física e mental dos trabalhadores, em particular pela adequação do trabalho e pela colocação em lugares de trabalho correspondentes às suas aptidões; contribuir ao estabelecimento do mais alto nível de bem-estar físico e mental dos trabalhadores.

No Brasil, os serviços médicos tornaram-se obrigatórios somente em 1976, com a Portaria 3237 do Ministério do Trabalho. A equipe multidisciplinar para a prevenção dos danos à saúde do trabalhador passou à obrigatoriedade somente em 1978, por força da Portaria 3214 do Ministério do Trabalho, que criou o Serviço Especializado de Segurança e Medicina do Trabalho (SESMT), com a participação obrigatória nas empresas de médicos,

restrita como a sua natureza, tem limites que se não podem ultrapassar. O exercício e o uso aperfeiçoam-na, mas é preciso que de quando em quando se suspenda para dar lugar ao repouso. Não deve, portanto, o trabalho prolongar-se por mais tempo do que as forças permitem. Assim, o número de horas de trabalho diário não deve exceder a força dos trabalhadores, e a quantidade de repouso deve ser proporcionada à qualidade do trabalho, às circunstâncias do tempo e do lugar, à compleição e saúde dos operários. O trabalho, por exemplo, de extrair pedra, ferro, chumbo e outros materiais escondidos debaixo da terra, sendo mais pesado e nocivo à saúde, deve ser compensado com uma duração mais curta. Deve-se também atender às estações, porque não poucas vezes um trabalho que facilmente se suportaria numa estação, noutra é de facto insuportável ou somente se vence com dificuldade". CARTA ENCÍCLICA "RERUM NOVARUM".

Vaticano.

Disponível

em:

$<$ http://www.vatican.va/holy_father/leo_xiii/encyclicals/documents/hf_l-xiii_enc_15051891_rerum-

novarum_po.html>. Acesso em: 21 abr. 2011. 
de engenheiros, de enfermeiros, de técnicos de segurança do trabalho e de auxiliares de enfermagem. Nessa fase também surgiram novas normas sobre ergonomia.

A última etapa cristaliza-se com a participação ativa do empregado no processo de combate e prevenção à doença e sua etiologia. O obreiro sai de sua posição inerte e promove a busca por melhores condições de trabalho. As regras constitucionais de destaque estão a seguir desenvolvidas.

A saúde é, então, objeto de um direito social. Essa consagração deu-se no art. $6^{\circ}$ da Constituição Federal de 1988. O direito social pode ser identificado a partir de uma dimensão subjetiva, como direitos a prestações públicas que são materializadas por meio de serviços e ações do Poder Público que permitam que o indivíduo partilhe os benefícios da vida em sociedade. Cogita-se em prestações públicas para a matéria de saúde.

Ao lado dessa identificação, o direito social pode ser enfocado a partir da premissa de que as relações sociais, formadas naturalmente, são o reflexo das forças que vigoram no fenômeno produtivo. É a conhecida dimensão objetiva. Dessa maneira, essas relações jurídicas necessitam da atividade moduladora do Estado; pois, ao verificar a desigualdade originária nelas, ele deve definir padrões de comportamento que proíbam o abuso de poder econômico. Esse é o campo do Direito do Trabalho ${ }^{46}$.

Portanto, o direito à saúde do trabalhador corresponde tanto ao direito subjetivo à prestação pública como à regulação e à normatização da relação de emprego.

No tocante ao direito subjetivo à prestação pública, a Constituição Federal de 1988, no artigo 200, inciso II, determina que compete ao Sistema Único de Saúde executar as ações de vigilância sanitária e epidemiológica, bem como as de saúde do trabalhador.

Já com relação ao direito de regulação e normatização da relação de emprego em matéria de saúde do trabalhador, o Estado procurou balizar essa relação pelas diversas disposições da Consolidação das Leis do Trabalho (CLT), tais como: a presença de serviços médicos e órgão de segurança nas empresas (artigos 162 e 163); a obrigatoriedade de realização de exames médicos nos empregados (artigo 168); regras específicas para edificações (artigos 170 a 174), iluminação (artigo 175), conforto térmico (artigo 176 a 178), instalações elétricas (artigos 179 a 181), movimentação, armazenagem e manuseio de materiais (artigos 182 e 183), máquinas e equipamentos (artigos 184 a 186), caldeiras, fornos e recipientes sob pressão (artigos 187 e 188). Quanto ao trabalho realizado em

${ }^{46}$ DALLARI, Sueli Gandolfi; NUNES JÚNIOR, Vidal Serrano. op. cit., p. 62. 
condições perigosas ou insalubres, o texto legal procurou também fixar as arestas para a continuidade da atividade econômica, ao estabelecer os percentuais de pagamento ao empregado em caso de trabalho nessas situações (artigos 189 a 197) ${ }^{47}$.

O Estado brasileiro também procurou preservar a saúde e integridade dos trabalhadores ao ratificar, principalmente, a Convenção 155 da OIT, que se refere à segurança e a saúde dos trabalhadores em todas as áreas de atividade econômica ${ }^{48}$.

$\mathrm{O}$ direito social engloba mecanismos que permitem aos próprios indivíduos a proteção dos direitos envolvidos. Esses mecanismos são as garantias, que são direitos que não outorgam um bem ou uma vantagem em si, mas são direitos-instrumentais para tutelar o direito principal ${ }^{49}$.

Além das garantias aplicáveis em defesa de qualquer direito trabalhista, como o acesso à jurisdição e às normas autônomas elaboradas no bojo das negociações coletivas, destaca-se o direito de recusa do empregado de executar qualquer tipo de atividade que coloque em risco sua vida e sua saúde.

Trata-se de uma das faces do ius resistentiae, que confere ao empregado o direito de não cumprir a ordem patronal quando ilegal ou quando o seu cumprimento resultar perigo de dano ou o próprio dano à sua integridade física ${ }^{50}$.

O direito de resistência é a oposição ao poder diretivo do empregador que, por sua vez, não é absoluto. A CLT, no artigo 483, qualifica a ordem patronal como falta grave em caso de ser exigido do empregado serviços superiores às suas forças ou impingir perigo de mal considerável.

A viabilidade do direito de resistência do empregado pode-se dar com a implementação da Comissão Interna de Prevenção de Acidentes (CIPA), uma vez que é sua incumbência a detecção de riscos inerentes ao trabalho e a orientação aos trabalhadores sobre esses riscos.

\footnotetext{
${ }^{47}$ No direito brasileiro, esse pagamento é feito pelos adicionais de periculosidade e insalubridade.

${ }^{48} \mathrm{O}$ Brasil ratificou outras Convenções da OIT sobre saúde e segurança referentes a categorias econômicas específicas, tais como: a Convenção 136, que protege contra os riscos de intoxicação pelo benzeno; a Convenção 162, que dispõe sobre a utilização do amianto com segurança; a Convenção 167, que dispõe sobre a segurança e saúde na construção. Disponível em: http://www.oit.org.br/convention. Acesso em 29 de outubro de 2012.

${ }^{49}$ SILVA, José Afonso da. Curso de direito constitucional positivo. 23. ed. São Paulo: Malheiros Ed., 2004. p. 416.

${ }^{50}$ CECÍlLIA, Silvana Louzada Lamattina. Responsabilidade do empregador por danos à saúde do trabalhador. São Paulo: LTr, 2008. p. 22.
} 
Portanto, o direito à saúde do empregado é um direito social em todas as faces, desde direito subjetivo à prestação pública, direito objetivo à normatização estatal e direito-instrumental de garantia.

Para o completo desenvolvimento da saúde do trabalhador, é imprescindível que as condições do meio ambiente do trabalho sejam adequadas. Então, veja-se.

\subsection{Direito fundamental ao meio ambiente}

\subsubsection{Conceito de meio ambiente e suas espécies}

A palavra ambiente indica esfera, círculo, o âmbito que nos cerca, em que vivemos. Dessa forma, o vocábulo já engloba a palavra meio. Todavia, o ambiente compõe-se de um conjunto de elementos naturais ou artificiais, cuja interação constitui e condiciona a vida do homem ${ }^{51}$. Logo, a expressão meio ambiente é mais rica de sentido por se referir a conexão de valores.

Em consonância com a Declaração de Estocolmo sobre o meio ambiente, de 1972, que centralizou o homem no meio ambiente, o legislador brasileiro definiu-o nos seguintes termos: "um conjunto de condições, leis, influências e interações de ordem química, física e biológica que permite, abriga e rege a vida em todas as suas formas" (artigo $3^{\circ}$, inciso I da Lei 6938/81).

José Afonso da Silva conceitua meio ambiente nos seguintes termos: "é a interação do conjunto de elementos naturais, artificiais e culturais que propiciem o desenvolvimento equilibrado da vida em todas as suas formas ${ }^{52}$ ". A integração busca assumir uma concepção unitária do ambiente, compreensiva dos recursos naturais, artificiais e culturais.

O conceito de José Afonso da Silva traz à baila três aspectos do meio ambiente, a saber: artificial, cultural e natural. O meio ambiente artificial é constituído pelo espaço urbano construído, que se manifesta no conjunto das edificações (espaço urbano fechado) e nos equipamentos públicos (ruas, praças, áreas verdes, espaços livres em geral: espaço

\footnotetext{
${ }^{51}$ PRIEUR, Michel. Droit de l'environnement. 5. ed. Paris: Dalloz, 2004. p. 2.

${ }^{52}$ SILVA, José Afonso da. Direito ambiental constitucional. 8. ed. São Paulo: Malheiros Ed., 2010. p. 18.
} 
urbano aberto). Já, o meio ambiente cultural é integrado pelo patrimônio histórico, artístico, arqueológico, paisagístico, turístico, que é agregado de valor especial que se adquiriu ou se impregnou ao longo da História. Por fim, o meio ambiente natural ou físico é composto pela interação dos seres vivos e seu meio, onde se dá a correlação recíproca entre as espécies e suas relações com o ambiente físico que ocupam.

Ao exercer o seu trabalho, o homem o faz no meio ambiente. Então, meio ambiente do trabalho é o local em que se desenvolve boa parte da vida do trabalhador, cuja qualidade de vida está intimamente ligada à qualidade desse ambiente. O meio ambiente do trabalho insere-se no meio ambiente artificial, para José Afonso da Silva.

Raimundo Simão de Melo ${ }^{53}$ e Celso Antonio Pacheco Fiorillo consideram o meio ambiente do trabalho um aspecto autônomo do meio ambiente, sendo que este último autor o define nos seguintes termos: "é o local onde as pessoas desempenham atividades laborais, sejam remuneradas ou não, cujo equilíbrio está baseado na salubridade do meio e na ausência de agentes que comprometam a incolumidade físico-psíquica dos trabalhadores, independentemente da condição que ostentem ${ }^{54,}$.

Apesar da importância dessa classificação dos aspectos do meio ambiente, filia-se ao seu duplo sentido adotado pela própria Declaração de Estocolmo, de 1972, que proclama que os dois aspectos do meio ambiente humano, o natural e o artificial, são essenciais para o bem-estar do homem e para o gozo de seus direitos fundamentais, inclusive, o direito à vida ${ }^{55}$.

Essa ordenação dual de meio ambiente é também preconizada pelo doutrinador Michel Prieur. Enquanto um dos sentidos aproxima-se de ecologia e refere-se ao equilíbrio de forças concorrentes que condicionam a vida de um grupo biológico; o outro, está relacionado aos arquitetos e urbanistas e corresponde a zona de contato entre um espaço construído e o meio ${ }^{56}$.

\footnotetext{
${ }^{53}$ MELO, Raimundo Simão de. Direito ambiental do trabalho e a saúde do trabalhador. 2. ed. São Paulo: LTr, 2006. p. 24.

${ }^{54}$ FIORILLO, Celso Antonio Pacheco. Curso de direito ambiental brasileiro. 7. ed. São Paulo: Saraiva, 2006. p. 43-44.

${ }^{55}$ ORGANIZAÇÃO DAS NAÇÕES UNIDAS. Declaração Sobre Meio Ambiente e Desenvolvimento. Disponível em: <http://www.direitoshumanos.usp.br/index.php/Meio-Ambiente/declaracao-sobre-meioambiente-e-desenvolvimento.html>. Acesso: 19 out. 2012.

${ }^{56}$ PRIEUR, Michel. op. cit., p. 2.
} 
Nesse sentido, o meio ambiente cultural e o do trabalho são espécies do meio

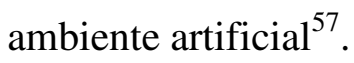

\subsubsection{Proteção jurídica ao meio ambiente do trabalho}

Dentro da necessidade humana de perseguir os valores de solidariedade e de fraternidade, os Estados positivaram normas jurídicas com o escopo de melhorar a saúde pública e de manter o equilíbrio ecológico. Esse conglomerado de normas jurídicas constitui o direito ambiental ou direito ao meio ambiente ${ }^{58}$.

Dessa forma, o direito ambiental está intimamente unido aos valores consagrados nas Declarações de Direitos e liberdades públicas.

A Declaração de Estocolmo, de 1972, reconheceu o direito ao meio ambiente como um direito humano ao prescrever que o homem tem um direito fundamental à liberdade, à igualdade e às condições satisfatórias de vida em um ambiente cuja qualidade permita viver em dignidade e com bem-estar (princípio $1^{\circ}$ ). A Carta africana dos direitos do homem e dos povos, de 1981, proclamou que todos os povos têm direito a um ambiente satisfativo e global, propício ao seu desenvolvimento (artigo 24). Esse documento recebeu um aditivo pelo Protocolo de São Salvador, que mencionou que toda pessoa tem direito de viver em um ambiente salubre (artigo 11-1). Finalmente, a Declaração sobre meio ambiente e desenvolvimento, do Rio de Janeiro, de 1992, enunciou que todos os seres humanos têm direito a uma vida sadia (princípio $\left.1^{\circ}\right)^{59}$.

Essa tutela estendeu-se, igualmente, ao meio ambiente do trabalho. A Organização Internacional do Trabalho prescreveu na Convenção 187 que todos os Estados-membros deverão fomentar e promover, em todos os níveis relevantes, o direito dos trabalhadores a um ambiente de trabalho seguro e saudável ${ }^{60}$. Assim, o direito ao meio ambiente saudável é um direito humano de terceira dimensão.

\footnotetext{
${ }^{57}$ Norma Sueli Padilha também considera apenas duas linhas mestras, quais sejam, o meio ambiente natural e o artificial, sendo este resultado da interferência e interação do homem com o meio. Logo, o meio ambiente cultural e o do trabalho são desdobramentos do meio ambiente artificial. PADILHA, Norma Sueli. Do meio ambiente do trabalho equilibrado. São Paulo: LTr, 2002. p. 27.

${ }^{58}$ PRIEUR, Michel. op. cit., p. 8.

${ }^{59}$ Id. Ibid., p. 58.

${ }^{60}$ ORGANIZAÇÃO INTERNACIONAL DO TRABALHO. Convenção 187. Disponível em: <http://www.institutoamp.com.br/oit187.htm>. Acesso em: 16 set. 2012.
} 
Com a finalidade de conferir maior efetividade, o meio ambiente foi erigido a direito fundamental pela Constituição Federal de 1988, que no artigo 225 estabeleceu que o meio ambiente ecologicamente equilibrado é bem de uso comum do povo e essencial à sadia qualidade de vida e constitui, simultaneamente, direito de todos e dever do Poder Público e da coletividade de defendê-lo e preservá-lo para as presentes e futuras gerações.

Infere-se do texto constitucional que todos têm direito ao meio ambiente ecologicamente equilibrado. Dessa forma, o meio ambiente é um bem jurídico constitucionalmente protegido, sendo de uso comum do povo, ou seja, um patrimônio coletivo.

Patrimônio é o conjunto de elementos necessários à realização, ao desenvolvimento do indivíduo ou da coletividade. O conteúdo do patrimônio ultrapassa a realidade econômica e não se compõe somente de bens comercializáveis, sendo considerado como um direito da personalidade do sujeito de direito, isto é, uma potência jurídica. O conceito de patrimônio é transtemporal e torna-se uma herança do passado que transita no presente e destina-se às gerações futuras.

Assim, o meio ambiente ecologicamente equilibrado é um patrimônio coletivo, isto é, um conjunto de condições básicas necessárias para manutenção e para a realização da sociedade enquanto comunidade. O desfrute do bem é comunitário e reverte-se ao bemestar individual conforme a posição de cada pessoa na sociedade ${ }^{61}$.

Esse bem-estar é consubstanciado na essencial qualidade de vida que se projeta além do direito à vida, pois as condições do meio são determinantes não somente para a sobrevivência, mas também para uma existência digna.

A expressão qualidade de vida traduz todo o necessário aparato interno e externo ao homem, dando-lhe condições de desenvolver suas potencialidades como indivíduo e como parte fundamental de uma sociedade. Segundo Cristiane Derani, a qualidade de vida no ordenamento brasileiro apresenta dois aspectos, a saber: o nível de vida material e o do bem-estar físico e o espiritual. A sadia qualidade de vida abarca o fato de que o mínimo material é sempre necessário para o deleite espiritual. O mínimo material para a consecução deste ideal é dado pelos elementos da realidade que historicamente informam esses princípios. Considerando o aspecto histórico-material do conceito de qualidade de vida, é possível seccioná-lo nas seguintes partes: a) aspecto físico, ou seja, ela deve indicar

\footnotetext{
${ }^{61}$ DERANI, Cristiane. Direito ambiental econômico. 2. ed. São Paulo: Max Limonad, 2001. p. 260-263.
} 
as condições mínimas do meio físico; b) referência antropológica, que se consubstancia no acesso e na abundância dos recursos naturais que diferenciam o desenvolvimento das sociedades e c) tutela do bem-estar que almeja atender às necessidades básicas, quais sejam: alimentação, habitação, saúde e educação ${ }^{62}$.

Ao lado do aspecto subjetivo do direito fundamental ao meio ambiente ecologicamente equilibrado, a Constituição impõe a dimensão objetiva que se consubstancia no dever de proteção do Estado e da coletividade de defendê-lo e preserválo para as presentes e futuras gerações.

O indivíduo deve ter um comportamento social frente à comunidade. O Poder Público tem a função ambiental pública de preservar o meio ambiente, que não lhe é uma atividade exclusiva. O preceito constitucional refere-se ao dever do Estado para efetivação dessa tutela ao meio ambiente ecologicamente equilibrado. Esse poder estatal é único e seu exercício é diluído na atividade administrativa a partir de competências constitucionalmente estabelecidas. Outrossim, o Estado deve editar normas para regular o uso adequado e racional dos recursos naturais.

Portanto, a Constituição brasileira trata o meio ambiente como um direito fundamental de todas as pessoas em sua dupla dimensão, isto é, como direito subjetivo e também como dever de proteção do Estado e da comunidade. A consideração do ambiente como tarefa ou fim normativo-constitucional implica a existência de deveres jurídicos ao Estado e demais poderes públicos e representa a faceta objetiva desse direito fundamental. Trata-se de uma norma impositiva que deve ser observada pelo Estado e pela comunidade ${ }^{63}$.

No tocante ao meio ambiente do trabalho, a Constituição Federal estabeleceu como direito subjetivo do trabalhador a redução dos riscos inerentes ao trabalho, por meio de normas de saúde, de higiene e de segurança (artigo $7^{\circ}$, XXII).

Esse direito fundamental vincula o Estado e o particular e, por isso, o empregador deve adotar medidas que concretizem o direito constitucional do trabalhador e, em contrapartida, o órgão estatal competente tem a função de fiscalizar e exigir o implemento das providências necessárias para minorar os riscos do trabalho. A Constituição Federal

\footnotetext{
${ }^{62}$ DERANI, Cristiane. op. cit., p. 83-84.

${ }^{63}$ CANOTILHO, José Joaquim Gomes. Estudos sobre direitos fundamentais. São Paulo: Ed. Revista dos Tribunais, 2008. p. 181.
} 
atribui dentre as competências do Sistema Único de Saúde a colaboração na proteção do meio ambiente, nele compreendido o do trabalho (artigo 200, inciso VIII).

Entretanto, caso seja impossível a eliminação integral dos riscos, o empregador tem a obrigação de fornecer os equipamentos de proteção individual e coletiva com o fim de neutralizá-los, bem como é o responsável pelo pagamento dos adicionais de insalubridade e periculosidade.

Por fim, todas essas obrigações têm uma direção prospectiva, qual seja, as gerações vindouras devem receber os mesmos recursos e condições existentes no presente para que possam manter o modo de vida atual. As relações de trabalho exigem que se preserve a força de trabalho para a continuidade da própria atividade econômica.

O direito ambiental repousa sobre grandes princípios com força normativa que são comuns para todos os povos do planeta em expressão da solidariedade mundial devido à globalização dos problemas ambientais. A Conferência de Estocolmo, de 1972, foi o ponto de partida para a elaboração de princípios próprios e a Conferência do Rio de Janeiro ampliou-os.

Veja-se a seguir os princípios ambientais e suas respectivas implicações na esfera trabalhista ${ }^{64}$.

\subsubsection{Princípio do desenvolvimento sustentável}

O princípio do desenvolvimento sustentável é aquele que determina a utilização parcimoniosa dos recursos naturais a fim de que possam ser reutilizados ${ }^{65}$. À medida que o bem é matéria-prima ao desenvolvimento, é elemento essencial à sadia qualidade de vida para todos os seres ${ }^{66}$.

A Declaração de Estocolmo de 1972 já garantiu implicitamente esse princípio ao prever que os recursos não renováveis devem ser usados com cautela para não serem esgotados, assim como o desenvolvimento econômico e social devem assegurar um meio de vida e de trabalho favorável, inclusive, com mecanismos de melhoria da própria

\footnotetext{
${ }^{64}$ Os princípios ambientais a seguir identificados seguem a nomenclatura de Michel Prieur, na obra Droit de l'environnement, cit., p. 51 e ss.

${ }^{65}$ PRIEUR, Michel. op. cit., p. 68.

${ }^{66}$ RODRIGUES, Marcelo Abelha. Instituições de direito ambiental. São Paulo: Max Limonad, 2002. v. 1, p. 136.
} 
qualidade de vida ${ }^{67}$. A consagração explícita deu-se na Declaração sobre meio ambiente e desenvolvimento do Rio de Janeiro, de 1992, que estabeleceu que a proteção do meio ambiente deve constituir parte integrante do desenvolvimento para se atingir o desenvolvimento sustentável (princípio $\left.4^{\circ}\right)^{68}$.

A Constituição Federal de 1988 incorporou esse princípio ao pontuar que a ordem econômica é fundada na livre iniciativa e na valorização do trabalho humano, assegurando a todos uma existência digna de acordo com os ditames de justiça social e observado, dentre outros, o princípio de defesa do meio ambiente (artigo 170, inciso VI).

No âmbito trabalhista, o busca de emprego deve ser acompanhada de qualidade e dignidade a fim de implementar o princípio do desenvolvimento sustentável.

Esse princípio foi perseguido pela Associação Nacional dos Procuradores do Trabalho (ANPT) e pela Associação Nacional dos Magistrados da Justiça do Trabalho (ANAMATRA), no Supremo Tribunal Federal, pelo ajuizamento da ação direta de inconstitucionalidade que visa declaração de inconstitucionalidade do artigo $2^{\circ}$ da Lei 9055/95, que trata da produção e comercialização do amianto na variedade crisotila, do grupo dos minerais das serpentinas, e demais fibras de mesma origem, usadas para o mesmo fim e, ainda, está pendente de julgamento ${ }^{69}$.

Como é cediço, o amianto é uma substância usada, principalmente, em telhas, gessos e outros elementos da construção civil, e causa desde asbestose ${ }^{70}$ até câncer pulmonar.

Assim, a eliminação do amianto representará a preservação da saúde dos trabalhadores e a sustentabilidade do desenvolvimento para as presentes e futuras gerações.

\footnotetext{
${ }^{67}$ ORGANIZAÇÃO DAS NAÇÕES UNIDAS. Declaração de Estocolmo sobre o meio ambiente humano. Disponível em: <http://www.direitoshumanos.usp.br/index.php/Meio-Ambiente/declaracao-de-estocolmosobre-o-ambiente-humano.html>. Acesso em: 26 set. 2012.

${ }^{68}$ ORGANIZAÇÃO DAS NAÇÕES UNIDAS. Declaração Sobre Meio Ambiente e Desenvolvimento, cit.

${ }^{69}$ SUPREMO TRIBUNAL FEDERAL. Ação Direta de Inconstitucionalidade (ADI 4066), Relator Ayres Britto. Disponível em: <http://www.stf.jus.br/portal/processo/verProcessoAndamento.asp?incidente=2607856>. Acesso em: 26 set. 2012.

${ }^{70}$ Asbestose é: "Pneumoconiose produzida pela inalação de fibras de asbesto e, que além de ocasionar fibrose pulmonar, pode estar acompanhada de câncer brônquico". FERREIRA, Aurélio Buarque de Holanda. Dicionário Aurélio da língua portuguesa. 5. ed. Curitiba: Positivo, 2010. p. 218.
} 


\subsubsection{Princípio da prevenção}

O princípio da prevenção consiste em evitar a ocorrência de danos ao meio ambiente por meio de medidas apropriadas ditas preventivas a partir da elaboração de um plano de trabalho ou de uma atividade ${ }^{71}$. Esse princípio foi veiculado na Convenção de Basileia sobre o controle de movimentos transfronteiriços de resíduos perigosos e seu depósito, de 1989. Esse diploma internacional previu, em seu preâmbulo, que a forma mais eficaz de proteger a saúde humana e o meio ambiente dos resíduos perigosos é reduzir sua geração em termos de quantidade e/ou potencial de seus riscos ${ }^{72}$.

O objetivo desse princípio é afastar a manifestação do risco conhecido e provado. Essa ação de evitar resultados danosos é preferível a medidas de reparação, de restauração ou de repressão que são feitas após uma violação ambiental.

Esse princípio da prevenção manifesta-se, na área trabalhista, por instrumentos administrativos e judiciais.

O Poder Executivo implementa o princípio da prevenção por meio da interdição do estabelecimento, do setor de serviço, da máquina ou do equipamento ou, ainda, com o embargo à obra se estiverem presentes o grave e iminente risco para o trabalhador (artigo 161, da CLT). Do mesmo modo, a autoridade estatal deverá indicar as providências que deverão ser adotadas para a prevenção de infortúnios de trabalho.

O Judiciário trabalhista depara-se com questões coletivas propostas pelo Ministério Público do Trabalho, pelos sindicatos, pelas associações civis com o fim de impor obrigações de fazer e de não fazer aos empregadores no tocante ao meio ambiente laboral em situações de risco grave e iminente, inclusive, com pedidos de interdição ou embargo da obra ${ }^{73}$.

Anteriormente à propositura dessa demanda coletiva, o Ministério Público, exclusivamente, poderá utilizar o inquérito civil público, que é um procedimento administrativo de natureza inquisitorial destinado a investigar fatos relevantes em diversos

\footnotetext{
${ }^{71}$ PRIEUR, Michel. op. cit., p. 71.

${ }^{72}$ MACHADO, Paulo Affonso Leme. Direito ambiental brasileiro. 14. ed. São Paulo: Malheiros Ed., 2006. p. 80-81.

${ }^{73}$ Súmula 736 do Supremo Tribunal Federal, in verbis: "Compete à Justiça do Trabalho julgar as ações que tenham como causa de pedir o descumprimento de normas trabalhistas relativas à segurança, higiene e saúde dos trabalhadores." SUPREMO TRIBUNAL FEDERAL. Súmula 736. Disponível em: $<$ ttp://www.stf.jus.br/portal/cms/verTexto.asp?servico=jurisprudenciaSumula\&pagina=sumula_701_800>. Acesso em: 19 set. 2012.
} 
assuntos não penais, sobretudo, o meio ambiente (artigo 129, inciso III, da Constituição Federal). Na esfera trabalhista, o ramo ministerial que tem atribuição para investigar eventuais irregularidades ambientais é o Ministério Público do Trabalho.

Esse órgão pode, também, emitir recomendações com o escopo de melhorar o meio ambiente laboral sem caráter vinculante, mas com implicações práticas de grande força moral, psicológica e política, em decorrência do artigo $6^{\circ}$, inciso XX, da Lei Complementar 75/93.

O Ministério Público do Trabalho e outros órgãos públicos poderão firmar termo de ajustamento de conduta às exigências legais (TAC), que é uma espécie de acordo entre o respectivo órgão e aquele que descumpriu normas jurídicas ambientais com o objetivo de adequar-se à conduta, mediante a cominação de astreintes. Trata-se de título executivo extrajudicial, que se não adimplido, enseja a execução direta na Justiça do Trabalho ao envolver questões do meio ambiente laboral (artigo 876 da CLT).

Ao lado do princípio da prevenção, existe o da precaução.

\subsubsection{Princípio da precaução}

A primeira manifestação escrita do princípio da precaução que se tem notícia foi a Charte que Jean de Lévis de Mirapoix editou, em 1303, para regulamentar a venda de carne a fim de enfrentar os perigos identificados naquela época ${ }^{74}$.

Todavia, somente com a Declaração do meio ambiente e desenvolvimento do Rio de Janeiro - Eco-92 - que o princípio da precaução foi consagrado com o escopo de proteger o meio ambiente (princípio 15). Quando houver ameaça de danos sérios e irreversíveis, a ausência absoluta de certeza científica não deve ser utilizada como razão para postergar medidas eficazes e economicamente viáveis para prevenir a degradação ambiental.

Assim, o princípio da precaução tem uma função pacificadora, firmando-se como postulado de atuar previamente contra um risco. De acordo com Cristiane Derani, o princípio da precaução sintetiza-se na busca do afastamento, no tempo e no espaço, do

\footnotetext{
${ }^{74}$ PRINCIPE de Précaution. Association des retraites du groupe (CEA). Disponível em: <http://www.energethique.com/fiches_pdf/telechargement.htm>. Acesso em: 19 set. 2012.
} 
perigo, na busca também da proteção contra o próprio risco e na análise do potencial danoso oriundo do conjunto de atividades. Sua manifestação dá-se, mais apropriadamente, na formação de políticas públicas ambientais, onde a exigência de utilização da melhor tecnologia disponível é necessariamente um corolário ${ }^{75}$.

No mesmo sentido, para Teresa Ancona Lopez, princípio da precaução é aquele referente aos rumos e aos valores do sistema de previsão de riscos hipotéticos, coletivos ou individuais, que assustam a comunidade ou os indivíduos isoladamente com danos graves e irreversíveis e sobre os quais não há certeza científica. O princípio da precaução requer a adoção de medidas drásticas e eficazes com o fim de antecipar o risco suposto e possível, mesmo em face da incerteza ${ }^{76}$.

O afastamento de riscos hipotéticos no meio ambiente do trabalho enseja uma série de providências dos empregadores, dos empregados e dos Poderes Estatais, haja vista que o princípio da precaução é também uma medida de controle da elaboração de regras.

O Poder Legislativo previu, na CLT, uma série de obrigações legais, das quais se destacam que as empresas são obrigadas a fornecer os equipamentos de proteção individual aos seus empregados, gratuitamente, adequados ao risco e em perfeito estado de conservação e funcionamento, sempre que as medidas de ordem geral não forem suficientes (artigo 166 da CLT). O empregador deve orientar e treinar os trabalhadores sobre o uso correto, guarda e conservação, bem como substituí-los quando danificados ou extraviados, responsabilizando-se pela sua higienização e pela manutenção periódica (artigo 157 da CLT).

Integrando a função legislativa, o Poder Executivo pode completar a lei, segundo o seu espírito e conteúdo, sobretudo nos aspectos que a própria lei outorga à esfera regulamentar. Dessa forma, o artigo 200 da CLT conferiu ao Ministério do Trabalho e Emprego a tarefa de estabelecer disposições complementares àquelas já previstas em matéria de atenuação dos riscos ambientais, tendo-se em vista as peculiaridades de cada setor.

Nesse diapasão, a Portaria 3214/78 do Ministério do Trabalho e Emprego veiculou as normas regulamentadoras (NR's) relativas à segurança e à medicina do

\footnotetext{
${ }^{75}$ DERANI, Cristiane. op. cit., p. 170.

${ }^{76}$ LOPEZ, Teresa Ancona. Princípio da precaução e evolução da responsabilidade civil. São Paulo: Quartier Latin, 2010. p. 103.
} 
trabalho. Veja-se, a seguir, as principais normas relacionadas ao afastamento de danos ambientais $^{77}$.

A norma regulamentadora $n^{\circ} 4$ (NR-4) estabeleceu que as empresas privadas, os órgãos públicos da administração direta e dos poderes Legislativo e Judiciário que tenham empregados celetistas manterão, obrigatoriamente, serviços especializados em engenharia de segurança e de medicina do trabalho, com a finalidade de promover a saúde e proteger a integridade do trabalhador no local de trabalho. Esses serviços serão compostos de médico do trabalho, engenheiro de segurança do trabalho, enfermeiro do trabalho, técnico de segurança do trabalho, auxiliar de enfermagem do trabalho, sendo o número de integrantes dimensionado conforme a gradação do risco da atividade principal e ao número total dos empregados do estabelecimento.

Referente ao cuidado de eliminar as doenças ocupacionais, a norma regulamentadora $n^{\circ} 7$ (NR 7) criou o Programa de Controle Médico de Saúde Ocupacional (PCMSO) destinado a precaução, ao rastreamento e ao diagnóstico precoce dos agravos à saúde relacionados ao trabalho, inclusive de natureza subclínica, além da constatação de casos de doenças profissionais ou danos irreversíveis à saúde do trabalhador, devendo ser planejado e implementado com base nos riscos à saúde. Essa norma prevê a realização de exames médicos admissional, periódico e demissional, considerando os riscos em que o trabalhador está submetido.

Finalmente, a norma regulamentadora $\mathrm{n}^{\circ} 9$ (NR-9) previu a obrigatoriedade para os empregadores da elaboração do Programa de Prevenção dos Riscos Ambientais (PPRA), com o escopo de preservar a saúde e a integridade física dos trabalhadores, por meio da antecipação, reconhecimento e avaliação e consequente controle dos riscos ambientais existentes ou que venham existir no meio ambiente de trabalho.

Um outro instrumento usado pelo Poder Executivo para evitar danos ambientais é Estudo Prévio de Impacto Ambiental (EPIA), cujo objetivo é apontar e avaliar os impactos e degradações ambientais gerados tanto na fase de implantação como na operação da atividade ou obra.

Essa atividade administrativa é exteriorização do poder de polícia, que é a faculdade discricionária que se reconhece à Administração Pública de restringir e

\footnotetext{
${ }^{77}$ MINISTÉRIO DO TRABALHO. Portaria 3214/78. Disponível em: <http://www010.dataprev.gov.br/sislex/paginas/63/mte/1978/3214.htm>. Acesso em: 24 set. 2012.
} 
condicionar o uso e o gozo dos direitos individuais, especialmente os de propriedade, em benefício do bem-estar geral ${ }^{78}$.

$\mathrm{Na}$ seara ambiental, o estudo de impacto ambiental exterioriza-se no conjunto de órgãos e serviços públicos incumbidos de fiscalizar, controlar e deter as atividades individuais que se revelem contrárias, inconvenientes ou nocivas à coletividade no tocante a diversos aspectos, tais como: segurança, higiene, saúde, domínio econômico, conservação dos ecossistemas ${ }^{79}$.

Esse poder de polícia ambiental está presente na exigência celetista de prévia inspeção e aprovação das instalações, para que o estabelecimento inicie suas atividades (artigo 160, da CLT). As modificações substanciais também devem ser comunicadas à Gerência Regional do Trabalho e Emprego para nova inspeção.

Ademais, o Poder Judiciário, se provocado, poderá atuar na concretização desse princípio ao proferir decisões, sobretudo, em caráter de urgência, para impedir condutas que acarretem danos irreversíveis diante de riscos hipotéticos e não previstos até então.

Assim, atinge-se a sustentabilidade das atividades humanas e a segurança das gerações futuras ao se seguir o princípio ambiental da precaução. $\mathrm{O}$ alcance efetivo dele depende substancialmente da forma e da extensão da cautela econômica, correspondente a sua realização.

\subsubsection{Princípio da informação}

O direito de informação é um direito fundamental de quarta dimensão que compreende a liberdade de receber ou de comunicar informações ${ }^{80}$. A Declaração do meio ambiente e desenvolvimento do Rio de Janeiro, de 1992, proclamou o direito à informação nas questões ambientais (princípio 10).

O direito à informação do meio ambiente laboral confere aos trabalhadores o acesso às reais condições ambientais a que estão expostos, bem como a própria organização do trabalho.

\footnotetext{
${ }^{78}$ MEIRELLES, Hely Lopes. Os poderes do administrador público. Revista de Direito Administrativo, Rio de Janeiro, Seleção histórica, p. 335, 1945-1995.

${ }^{79}$ Autores favoráveis à exigência de estudo prévio de impacto ambiental para o meio ambiente de trabalho: PADILHA, Norma Sueli. op. cit., p. 118-121; MELO, Raimundo Simão de. op. cit., p. 79.

${ }^{80}$ PRIEUR, Michel. op. cit., p. 105.
} 
Nesse sentido, a Convenção 161 da OIT diz que todos os trabalhadores devem ser informados sobre os riscos inerentes ao trabalho, e a Convenção 148 da OIT estabelece que os trabalhadores ou os seus representantes poderão apresentar propostas, receber informações e orientações, recorrer em instâncias apropriadas, a fim de garantir a proteção contra os riscos profissionais devidos à contaminação do ar, do ruído e das vibrações nos locais de trabalho.

A Consolidação das Leis do Trabalho pontua a necessidade das informações no ambiente de trabalho ao determinar que o Ministério do Trabalho e Emprego adote regras informacionais sobre: a) a obrigatoriedade de indicar a carga máxima permitida nos equipamentos de transporte; b) os avisos de proibição de fumar e da advertência quanto à natureza perigosa ou nociva à saúde, das substâncias em movimentação ou em depósito; c) as recomendações de primeiros socorros e de atendimento médico e d) símbolo de perigo, padronizado internacionalmente, nos rótulos dos materiais ou das substâncias armazenadas ou transportadas (artigos 182, inciso III, e 197).

A norma regulamentar $\mathrm{n}^{\mathrm{o}} 5$ (NR 5), de 17/08/92, atribuiu à Comissão Interna de Prevenção de Acidentes, em colaboração como o Serviço Especializado de Segurança e Medicina do Trabalho (SESMT) das empresas e após a oitiva dos trabalhadores, a elaboração do mapa de risco ambiental, com a identificação de todos os riscos no local de trabalho ${ }^{81}$. Esse mapa deverá ser publicado em locais visíveis no meio ambiente laboral para que os trabalhadores sejam informados.

Decorre do princípio da informação, a obrigatoriedade de o empregador elaborar o Perfil Profissiográfico Previdenciário (PPP) que é um documento histórico-laboral pessoal/individual do trabalhador, com propósitos previdenciários, para a obtenção de informações relativas à fiscalização do gerenciamento de riscos e existência de agentes nocivos no ambiente de trabalho, para orientar e subsidiar nos processos de reconhecimento de aposentadoria especial (artigo 68, $\S 6^{\circ}$, do Decreto 3048/99). Na rescisão do contrato de trabalho ou no desligamento do cooperado, o empregador deverá entregar-lhe uma cópia, sob pena de multa. Infere, então, que o Perfil Profissiográfico Previdenciário é um documento obrigatório para os empregados, avulsos e cooperados.

Dessa forma, os trabalhadores informados são aptos para uma participação efetiva no local de trabalho.

\footnotetext{
${ }^{81}$ MINISTÉRIO DO TRABALHO E EMPREGO. $N R \quad 5 . \quad$ Disponível em: <portal.mte.gov.br/data/files/.../nr_05.pdf>. Acesso em: 20 set. 2012.
} 


\subsubsection{Princípio da participação}

O direito fundamental ao meio ambiente traz, ao Poder Público em todas as esferas e à coletividade, os deveres de proteção. Todos esses deveres decorrentes da participação social coadunam-se à implementação dos princípios da prevenção e da precaução, isto é, todas as atividades são orientadas a prevenir os acidentes do trabalho. A Declaração de Estocolmo evocou os meios para que o público tivesse pleno conhecimento de sua responsabilidade a respeito do meio ambiente (princípios $4^{\circ}$ e 19).

Não só o Poder Público, conforme já tratado durante os princípios da prevenção e da precaução, mas também a sociedade civil têm o dever de cooperação para manter a integridade ambiental. Essa participação dos cidadãos, sozinhos ou em grupo, constitui uma contribuição maior para a democracia e decorre das próprias características do dano ambiental, quais sejam, universalidade, duração, interdependência e irreversibilidade.

Desse princípio houve a produção da regra que conferiu legitimidade para o cidadão, individualmente, defender o meio ambiente pelo ajuizamento de ação popular com a finalidade de anular ato lesivo ao meio ambiente, isentando-o de custas judiciais e do ônus da sucumbência, salvo se comprovada a má-fé (artigo $5^{\circ}$, inciso LXXIII, da Constituição).

Uma outra regra participativa é a previsão de os empregados formarem as Comissões Internas de Prevenção de Acidentes (CIPAs), que são órgãos paritários de representação nos locais de trabalho. As funções das CIPAs são: cuidar e zelar por adequadas condições nos ambientes de trabalho, apontar as condições de risco, orientar os empregados quanto às técnicas de prevenção, solicitar ao empregador medidas para neutralizar os riscos e, assim, prevenir a ocorrência de sinistros.

Essa participação do empregado no meio ambiente laboral pode se apresentar por uma atitude omissiva de grande relevância, que é a greve ambiental. Greve ambiental para Raimundo Simão de Melo é uma interrupção coletiva ou individual, temporária, parcial ou total da prestação de serviços a um tomador, no âmbito de qualquer relação de trabalho, com o objetivo de proteger o meio ambiente do trabalho de todos os ataques que possam atingir a saúde e a segurança dos trabalhadores ${ }^{82}$.

\footnotetext{
${ }^{82}$ MELO, Raimundo Simão de. op. cit., p. 84.
} 
O referido autor inova ao inserir a paralisação individual como uma das manifestações desse tipo de greve. O fundamento para tal comportamento é o risco grave e iminente no local de trabalho.

Ao contrário da greve tradicional, a ambiental assegura ao trabalhador o direito aos salários. Essa previsão está contida nas Constituições dos Estados de Rondônia ${ }^{83}$ e de São Paulo ${ }^{84}$, que garantem a interrupção do trabalho, sem prejuízo salarial e de outros direitos, no caso de risco grave e iminente, até a eliminação total (artigos 244, inciso III e $229, \S 2^{\circ}$, respectivamente).

Paralisações têm por finalidade preservar e defender o meio ambiente de trabalho, qualquer que seja o local e o vínculo formado entre as partes.

Greves ambientais podem desenrolar-se em dissídio coletivo. Segundo Ronaldo Lima dos Santos, dissídio coletivo é um mecanismo heterônimo-judicial de resolução de conflitos coletivos do trabalho, no qual a Justiça do Trabalho se utiliza de seu poder normativo, isto é, estabelece normas e condições de trabalho para regular as relações individuais de trabalho entre trabalhadores e empregadores; soluciona controvérsia sobre a aplicação ou interpretação de norma jurídica; ou delibera sobre os efeitos jurídicomateriais provenientes de uma greve ${ }^{85}$.

Dessa forma, a Justiça do Trabalho poderá fixar normas sobre o meio ambiente do trabalho quando provocada pelas entidades sindicais, pelas empresas, comissão de negociação composta por trabalhadores e pelo Ministério Público do Trabalho. Esse último órgão somente é legitimado para suscitar o litígio na hipótese de movimento paredista em atividades essenciais com possibilidade de lesão ao interesse público (artigo 114 , $\S 3^{\circ}$, da Constituição Federal).

Finalmente, essa participação comissiva ou omissiva culmina nos processos decisórios com um diálogo entre os diversos atores sociais. É o chamado princípio da cooperação ou concertação.

\footnotetext{
${ }^{83}$ ASSEMBLEIA DO ESTADO DE RONDÔNIA. Constituição do Estado de Rondônia. Disponível em: $<$ http://www.ale.ro.gov.br/portal/Mostrar.aspx?idConteudo=3718>. Acesso em: 24 set. 2012.

${ }^{84}$ ASSEMBLEIA DO ESTADO DE SÃO PAULO. Constituição do Estado de São Paulo. Disponível em: <http://www.al.sp.gov.br/repositorio/legislacao/constituicao/1989/constituicao\%20de\%2005.10.1989.htm>. Acesso em: 24 set. 2012.

${ }^{85}$ SANTOS, Ronaldo Lima dos. Sindicatos e ações coletivas: acesso à justiça coletiva e tutela dos interesses difusos, coletivos e individuais homagêneos. 2. ed. São Paulo: LTr, 2008. p. 275.
} 


\subsubsection{Princípio da cooperação}

O princípio da cooperação informa uma ação conjunta do Estado e da sociedade na escolha de prioridades e nos processos decisórios. Ele é o alicerce dos instrumentos normativos que são criados com objetivos de aumento da informação e da ampliação de participação nos processos de política ambiental, bem como no relacionamento entre liberdade individual e necessidade social.

Para a tutela do meio ambiental laboral, destaca-se a negociação coletiva, que é um procedimento de composição de interesses desde as discussões entre empregados e empregadores até qualquer debate tripartite. Ressalva-se, porém, os limites dessa negociação coletiva no tocante ao respeito às normas de ordem pública, que são indisponíveis, como as do meio ambiente de trabalho.

A ênfase dá-se nas negociações tripartites entre empregadores, empregados e governo que caminham para uma convergência de vontades ou atitudes dos atores sociais que, por sua vez, pactuam sobre situações e assuntos de interesse social e econômico. Esse procedimento negocial é chamado de concertação social, cujo resultado é o pacto social. Pacto social é um negócio jurídico atípico, que traça as diretrizes gerais que deverão ser observadas pelos grupos sociais em sua política e na elaboração de normas coletivas ${ }^{86}$.

É possível a realização de audiências públicas nas quais os cidadãos e as entidades civis podem obter informações, depoimentos, sugestões e críticas que favorecem o diálogo e a negociação.

Uma atuação coordenada das entidades sindicais e Estado que merece destaque é a concertação social do benzeno entre entidades dos trabalhadores, das indústrias e do governo, que reconheceu essa substância como cancerígena, para a qual não existe um limite seguro na exposição. Esse pacto social estabeleceu um conjunto de ações, de atribuições e de procedimentos para a prevenção à exposição ocupacional ao benzeno, com o escopo de proteger o meio ambiente do trabalho e, por via reflexa, a saúde do trabalhador ${ }^{87}$.

\footnotetext{
${ }^{86}$ Id. Ibid., p. 178-188.

${ }^{87}$ MELO, Raimundo Simão de. op. cit., p. 68-69.
} 


\subsubsection{Princípios do poluidor-pagador e do ônus social}

O princípio do poluidor-pagador é aquele que permite uma internalização dos custos sociais externos de deterioração ambiental que acompanham a produção industrial ${ }^{88}$. Assim, aquele que causar um problema ambiental deverá arcar com os custos da diminuição ou afastamento do dano. Esse princípio foi consagrado na Declaração do Rio, de 1992 (princípio 16).

A internalização dos custos ambientais concentra-se até o limite em que não se sobrecarrega o valor dos custos da produção, porque, se levar a utilização do princípio do poluidor-pagador até os seus limites, chegar-se-ia à paralisação da dinâmica do mercado, por um aumento de preços impossível de ser absorvido nas relações de troca ${ }^{89}$.

Em antítese ao princípio do poluidor-pagador, tem-se o princípio do ônus social. Dessa forma, as medidas de implementação da qualidade ambiental devem ter seus custos arcados pela coletividade, isto é, pelo conjunto de pagadores de impostos, sem se observar a utilidade relativa que cada indivíduo retiraria. O exercício se dá pela cobrança pelo Estado de impostos e taxas ambientais visando à conservação desse bem difuso ${ }^{90}$.

Uma das manifestações desse princípio na área trabalhista é pela concessão de incentivo fiscal para as empresas que reduziram os acidentes de trabalho e, ao mesmo tempo, ampliação da carga tributária da contribuição social ao seguro de acidente de trabalho (SAT) daquelas empresas que aumentaram esses infortúnios ${ }^{91}$.

Desse princípio é possível inferir três regras jurídicas: a) responsabilidade civil objetiva; b) prioridade da reparação específica e c) solidariedade para suportar os danos causados ao ambiente.

A responsabilidade civil objetiva em matéria ambiental foi regulada pela Lei 6938/81, em seu artigo 14, $\S 1^{\circ}$. Assim, o poluidor é obrigado, independentemente da existência de culpa, a indenizar ou a reparar os danos causados ao meio ambiente e a terceiros afetados pela atividade. Esse dispositivo foi recepcionado pela Constituição

\footnotetext{
${ }^{88}$ PRIEUR, Michel. op. cit., p. 145.

${ }^{89}$ DERANI, Cristiane. op. cit., p. 163.

${ }^{90}$ SANTOS, Enoque Ribeiro dos. Responsabilidade objetiva e subjetiva do empregador. 2. ed. São Paulo: LTr, 2008. p. 169.

${ }^{91}$ Essas regras serão enfrentadas no capítulo 2 da presente dissertação.
} 
Federal de 1988, que previu que os infratores responderão penal e administrativamente e terão a obrigação de reparar o dano (artigo $225, \S 3^{\circ}$ ).

A nova ordem constitucional também previu a prioridade da reparação específica e, sucessivamente, a reparação em pecúnia (artigo $225, \S 2^{\circ}$ ).

Finalmente, a responsabilidade ambiental é solidária, ou seja, todos aqueles que se aproveitaram da atividade produtiva responderão por eventuais danos.

Como é cediço, ao não serem seguidas as regras estatais de preservação do meio ambiente laboral, fere-se o direito fundamental ao meio ambiente saudável, e uma das consequências possíveis é o acidente do trabalho que tem seu próprio tratamento.

A aplicação das regras de responsabilidade ambiental para o meio ambiente do trabalho gera controvérsias, em virtude de outra norma prevista no artigo $7^{\circ}$, inciso XXVIII, da Constituição que prevê, como um dos direitos do trabalhador, a existência de um seguro, a cargo do empregador, em caso de acidente do trabalho, sem excluir a indenização a que está obrigado quando incorrer em dolo ou culpa. Esse dispositivo traz o elemento culpa para a responsabilidade civil decorrente do acidente do trabalho.

O desafio de saber o verdadeiro alcance dessas normas constitucionais de responsabilidade pelo acidente do trabalho, dentro do pressuposto do direito laboral de conferir uma maior tutela jurídica ao trabalhador acidentado, será o ponto fulcral das páginas seguintes. 


\section{ACIDENTE DO TRABALHO E RESPONSABILIDADE}

\subsection{Acidente do trabalho}

Acidente é um acontecimento imprevisto ou fortuito que resulta dano à coisa ou à pessoa. Aurélio Buarque de Holanda Ferreira diz que acidente do trabalho é:

Toda lesão corporal ou perturbação funcional que, no exercício ou por motivo do trabalho, resultar causa externa, súbita, imprevista ou fortuita, determinando a morte do empregado ou sua incapacidade para o trabalho, total ou parcial, permanente ou temporária ${ }^{92}$.

Esse conceito de acidente do trabalho está relacionado com o liberalismo econômico do século XIX, que propugnou que os acidentados não receberiam indenização pelos danos sofridos se esses fossem decorrentes de fatalidades que não poderiam ser evitadas $^{93}$. Aplicava-se, àquela época, o direito civil comum e, consequentemente, a vítima somente receberia indenização se provasse a culpa do patrão. O resultado era que três quartos dos acidentes ficavam a cargo dos trabalhadores que não conseguiam demonstrar a culpa do empregador ${ }^{94}$.

Essa concepção refletiu nas primeiras legislações sobre acidente do trabalho.

Tendo como premissa a lei francesa, de 9 de abril de 1898, sobre acidente do trabalho, André Rouast e Maurice Givord afirmaram que o acidente é um fato súbito e sempre violento, cuja causa é externa ao trabalho que causa lesão corporal ${ }^{95}$.

Para Mozart Victor Russomano, acidente do trabalho é um acontecimento em geral súbito, violento e fortuito, vinculado ao serviço prestado a outrem pela vítima que lhe determina lesão corporal ${ }^{96}$.

Todavia, essa visão não pode mais perdurar na modernidade, haja vista que a maioria dos acidentes do trabalho decorre da falta de prevenção dos ambientes de trabalho

\footnotetext{
${ }^{92}$ FERREIRA, Aurélio Buarque de Holanda. op. cit., p. 36.

${ }^{93}$ MELO, Raimundo Simão de. op. cit., p. 200.

${ }^{94}$ SACHET, Adrien. Traité théorique et pratique de la legislation sur les accidents du travail. 2. ed. Paris: Librairie de la société du recueil general des lois \& des arrêts, 1904. t. 1, p. 5.

${ }^{95}$ ROUAST, André; GIVORD, Maurice. Traité du Droit des accidents du travail et des maladies professionelles. Paris: Dalloz, 1934. p. 99.

${ }^{96}$ RUSSOMANO, Mozart Victor. Comentários à Consolidação das Leis da Previdência Social. 2. ed. São Paulo: Ed. Revista dos Tribunais, 1981. p. 395.
} 
e da ausência de respeito às normas de medicina e de segurança do trabalho, e não do mero acaso.

Os reflexos sociais desses acidentes levaram ao surgimento de normas para a proteção do acidentado e dos seus dependentes para, ao menos, remediar a situação. Assim, o conceito atual de acidente do trabalho exclui a causa externa, fortuita, como condição sine qua non do evento danoso, uma vez que a maioria dos acidentes é previsível.

Dessa forma, para Pontes de Miranda, acidente do trabalho é o evento que causa dano físico ou psíquico ao empregador, originário de fato que se relaciona às atribuições de trabalho, consoante o lugar e o tempo em que deva ser exercido ${ }^{97}$.

Philippe Malingrey diz que o acidente do trabalho é todo aquele ocorrido em razão do trabalho ou por sua ocasião ${ }^{98}$.

Nesse sentido, Gustavo Filipe Barbosa Garcia preceitua que acidente do trabalho é o infortúnio em virtude do trabalho que ocasiona morte ou incapacidade ${ }^{99}$.

O acidente do trabalho ganhou um sentido elástico e alcançou também as moléstias profissionais. Essas são provenientes da prestação de serviços e determinam dano físico e/ou psíquico. A subitaneidade é o elemento distintivo entre o acidente e a doença, uma vez que a doença pressupõe ação prolongada sobre o organismo ${ }^{100}$. Então, a violência do acidente típico é sempre decrescente e da moléstia profissional é contínua, progressiva.

Nesse sentido, Lorenzo Borri diz que doença ocupacional é aquele prejuízo à saúde do trabalhador que se desenvolve lentamente a partir não apenas do processo patológico intrínseco da entidade mórbida, mas também pelas condições peculiares e circunstanciais da atividade profissional ${ }^{101}$.

Portanto, entende-se que acidente do trabalho é aquele evento, súbito ou paulatino, que causa danos à saúde do trabalhador, sendo decorrente do exercício da atividade profissional.

\footnotetext{
${ }^{97}$ PONTES DE MIRANDA, Francisco Cavalcanti. Tratado de direito privado. 3. ed. São Paulo: Ed. Revista dos Tribunais, 1984, t. 54, p. 83.

${ }^{98}$ MALINGREY, Philippe. Cadre juridique de la prevention et de la reparation des risques profissionnels. Paris: Lavoisier, 2009. p. 117.

${ }^{99}$ GARCIA, Gustavo Filipe Barbosa. Acidentes do trabalho: doenças ocupacionais e nexo técnico epidemiológico. 4. ed. São Paulo: Método, 2011. p. 17.

${ }^{100}$ ROUAST, André; GIVORD, Maurice. op. cit., p. 100.

${ }^{101}$ BORRI, Lorenzo. Trattato di infortunistica. Milano: Società Editrice Libraria, 1918. v. 1, p. $23-25$.
} 


\subsubsection{Conceito legal de acidente do trabalho}

Em face das dificuldades de conceituar acidente do trabalho, Lorenzo Borri preconizou a necessidade de se utilizar de enunciados descritivos aptos a conduzir a interpretação se fato singular constitui ou não o acidente, consoante as condições e as circunstâncias em que o evento tenha ocorrido ${ }^{102}$.

Nessa seara, o legislador brasileiro definiu, nas normas heterônomas, o acidente do trabalho com os dados que dispunha. O conceito legal de acidente do trabalho não abrange todas as hipóteses de eventos danosos. O legislador preferiu separá-los em acidentes típicos ${ }^{103}$ ou stricto sensu e equiparar outras situações ao conceito. Dessa forma, têm-se os acidentes típicos e os acidentes por equiparação.

\subsubsection{Acidentes típicos e por equiparação}

O artigo 19 da Lei 8213/91 estabelece que acidente do trabalho é aquele que ocorre pelo exercício do trabalho a serviço da empresa ou pelo exercício do trabalho dos segurados referidos no inciso VII do artigo 11 dessa Lei, provocando lesão corporal ou perturbação funcional, que causa a morte ou a perda ou a redução, permanente ou temporária, da capacidade para o trabalho.

O acidente típico é um evento súbito que produz violação à integridade do indivíduo, isto é, resulta lesão corporal ou perturbação funcional. A lesão ou a perturbação necessitam ocasionar morte ou uma incapacidade, permanente ou temporária, para o trabalho, com o fim de configurar o acidente. Lesão corporal é aquela que atinge a integridade física do indivíduo, causando-lhe um dano físico-anatômico, enquanto a perturbação funcional é a que, sem aparentar lesão física, apresenta um dano fisiológico ou psíquico, relacionado com órgãos ou funções específicas do organismo humano ${ }^{104}$. Esse é o elemento objetivo para a caracterização do acidente do trabalho.

\footnotetext{
${ }^{102}$ BORRI, Lorenzo. op. cit., p. 14.

${ }^{103}$ Também se utiliza a nomenclatura acidentes-tipo para esses sinistros.

${ }^{104}$ OLIVEIRA, José de. Acidentes do trabalho: teoria, prática, jurisprudência. 2. ed. São Paulo: Saraiva, 1992. p. 3.
} 
O elemento subjetivo é irrelevante para a caracterização do acidente do trabalho, ou seja, não se perquire a culpa do segurado. Aplica-se a teoria do risco social, segundo a qual a sociedade arca com o ônus do indivíduo incapacitado, independentemente de quem causou o infortúnio ${ }^{105}$.

O exercício do trabalho a serviço da empresa é uma circunstância causal desencadeadora do acidente. Exclui-se, dessa forma, o acidente ocorrido fora do domínio dos deveres e das obrigações decorrentes do trabalho. Não é necessário que o fato tenha ocorrido no ambiente de trabalho, mas somente que seja em decorrência do trabalho ${ }^{106}$.

A lei brasileira indica quais são os segurados que têm direito ao benefício acidentário, ou seja, os empregados (incluídos os temporários), os trabalhadores avulsos ${ }^{107}$ e os segurados especiais ${ }^{108}$.

À relação entre o dano sofrido pela vítima e sua atividade laborativa dá-se o nome de nexo causal. Incumbe a perícia médica do INSS investigar o nexo de causalidade entre a lesão, perturbação ou morte e o fato, bem como tipificar o evento como sendo em decorrência do trabalho.

Ainda que o empregador não tenha dado causa direta ao acidente, a legislação previdenciária considera como acidente do trabalho aquele sofrido pelo segurado no local e no horário do trabalho, em consequência de: a) ato de agressão, sabotagem ou terrorismo praticado por terceiro ou companheiro de trabalho; b) ofensa física intencional, inclusive de terceiro, por motivo de disputa relacionada ao trabalho; c) ato de imprudência, de negligência ou de imperícia de terceiro ou de companheiro de trabalho; d) ato de pessoa

\footnotetext{
${ }^{105} \mathrm{O}$ risco social será tratado detidamente, nesse capítulo, no item 2.2.2.

${ }^{106}$ CASTRO, Carlos Alberto Pereira de; LAZZARI, João Batista. Manual de direito previdenciário. 14. ed. Florianópolis: Conceito Editorial, 2012. p. 554.

${ }^{107}$ De acordo com o artigo 11, inciso VI, da Lei 8213/91, trabalhador avulso é "quem presta, a diversas empresas, sem vínculo empregatício, serviço de natureza urbana ou rural definidos no Regulamento". CONGRESSO NACIONAL. $\quad$ Lei 8213/91. Disponível em: $<$ http://www.planalto.gov.br/ccivil_03/Leis/L8213cons.htm>. Acesso em: 25 out. 2012.

${ }^{108}$ Consoante o artigo 11, inciso VII, da Lei 8213/91, segurado especial é: “a pessoa física residente no imóvel rural ou em aglomerado urbano ou rural próximo a ele que, individualmente ou em regime de economia familiar, ainda que com o auxílio eventual de terceiros, na condição de: a) produtor, seja proprietário, usufrutuário, possuidor, assentado, parceiro ou meeiro outorgados, comodatário ou arrendatário rurais, que explore atividade: 1 . agropecuária em área de até 4 (quatro) módulos fiscais; 2 . de seringueiro ou extrativista vegetal que exerça suas atividades nos termos do inciso XII do caput do art. $2^{\circ}$ da Lei 9.985, de 18 de julho de 2000, e faça dessas atividades o principal meio de vida; b) pescador artesanal ou a este assemelhado que faça da pesca profissão habitual ou principal meio de vida; e c) cônjuge ou companheiro, bem como filho maior de 16 (dezesseis) anos de idade ou a este equiparado, do segurado de que tratam as alíneas a e $b$ deste inciso, que, comprovadamente, trabalhem com o grupo familiar respectivo". CONGRESSO NACIONAL. Lei 8213/91, cit.
} 
privada do uso da razão; e) desabamento, inundação, incêndio e outros casos fortuitos ou decorrentes de força maior (artigo 21, inciso II, da Lei 8213/91).

Também são elementos formativos do conceito o acidente que atinge o segurado, ainda que fora do local e horário de trabalho: a) na execução de ordem ou na realização de serviço sob a autoridade da empresa; b) na prestação espontânea de qualquer serviço à empresa para lhe evitar prejuízo ou proporcionar proveito; c) em viagem a serviço da empresa, inclusive para estudo quando financiada por essa dentro de seus planos para melhor capacitação da mão de obra, independentemente do meio de locomoção utilizado, inclusive veículo de propriedade do segurado; d) no percurso da residência para o local de trabalho ou deste para aquela, qualquer que seja o meio de locomoção, inclusive veículo de propriedade do segurado (artigo 21, inciso IV, da Lei 8213/91). Essa hipótese derradeira é o acidente in itinere ou de trajeto, que se caracteriza por ter ocorrido fora do ambiente de trabalho, haja vista que atinge o segurado entre sua residência e o seu local de trabalho. Pequenas alterações no percurso não têm o condão de descaracterizar o acidente do trabalho.

Por fim, independentemente do horário e do local de trabalho, é acidente para fins previdenciários a doença proveniente de contaminação acidental do empregado no exercício de sua atividade (artigo 21, inciso III, da Lei 8213/91).

A lei, ainda, considera acidente do trabalho o evento que, não sendo considerado causa única, haja contribuído diretamente para a morte do segurado ou para a redução de sua capacidade laborativa. Trata-se da concausa, que é outra causa que, juntando-se à principal, concorre para o resultado. Ela reforça o processo causal e pode ser antecedente, superveniente ou concomitante (artigo 21, inciso I, da Lei 8213/91).

A legislação regulamenta que o empregado está no exercício do trabalho durante os períodos destinados à refeição ou ao descanso, ou naqueles destinados à satisfação de outras necessidades fisiológicas, no local do trabalho (artigo 21, inciso IV, $\S 1^{\text {o }}$, da Lei 8213/91). Outrossim, existe a previsão legal de que não é considerada agravação ou complicação de acidente do trabalho a lesão que, resultante de acidente de outra origem, se associe ou se superponha às consequências do anterior (artigo 21, inciso IV, § $2^{\circ}$, da Lei 8213/91).

Portanto, são situações que, mesmo quando ocorrem no local e no horário de trabalho, não estão diretamente relacionadas com a atividade profissional, apesar do 
vínculo indireto. Ademais, são mencionados como acidentes aqueles ocorridos fora do local ou do horário de trabalho, mas que guardam vinculação estreita com o cumprimento do contrato laboral. Essas causas são o suporte fático somente para a concessão dos benefícios previdenciários pelo Instituto Nacional do Seguro Social (INSS), e não para a indenização alicerçada na responsabilidade civil do empregador, pois esses fatos não são decorrentes do risco inerente ao exercício da atividade profissional.

Finalmente, a lei inclui as doenças ocupacionais como acidentes do trabalho.

\subsubsection{Doenças ocupacionais e o nexo técnico epidemiológico}

A lei equipara as doenças ocupacionais aos acidentes do trabalho para fins meramente jurídicos. A doença vai se instalando insidiosamente e se manifesta internamente, com tendência de agravamento ${ }^{109}$.

O artigo 20, da Lei 8213/91, distingue as doenças ocupacionais em doenças do trabalho e em doenças profissionais. Enquanto a doença profissional é aquela produzida ou desencadeada pelo exercício do trabalho peculiar a determinada atividade e constante da respectiva relação elaborada pelo Ministério do Trabalho e Previdência Social, a doença do trabalho é a adquirida ou desencadeada em função de condições especiais em que o trabalho é realizado e com ele se relaciona diretamente, constante da relação elaborada pelo Ministério do Trabalho e Previdência Social.

As doenças profissionais, sendo aquelas peculiares a determinada atividade ou profissão, são conhecidas também como tecnopatias ou ergopatias. A relação com o trabalho é presumida iuris et de iure, não sendo permitida prova em sentido contrário.

Por outro lado, as doenças do trabalho surgem da forma em que o trabalho é prestado ou das condições específicas do ambiente do trabalho. Essas doenças do trabalho são chamadas de mesopatias e não têm nexo causal presumido, necessitando de prova de que a patologia deu-se em virtude das condições em que o trabalho foi realizado.

\footnotetext{
${ }^{109}$ OLIVEIRA, Sebastião Geraldo. Indenizações por acidente do trabalho ou doença ocupacional. 2. ed. São Paulo: LTr, 2006. p. 44.
} 
Tanto as doenças profissionais quanto as do trabalho estão inseridas no Anexo II do atual Regulamento da Previdência Social. Todavia, esse rol não é taxativo, apenas exemplificativo.

Cumpre mencionar que algumas doenças são excluídas da lista de doenças ocupacionais, a saber: a doença degenerativa, a inerente ao grupo etário, a que não produza incapacidade laborativa e a doença endêmica adquirida por segurado habitante de região em que ela se desenvolva, salvo comprovação de que é resultante de exposição ou contato direto determinado pela natureza do trabalho (artigo 20, inciso I, da Lei 8213/91). Nesses casos, a doença não tem nexo causal com o trabalho, apareceu no trabalho, mas não pelo trabalho.

Consoante já assinalado, a caracterização do acidente do trabalho exige que a enfermidade seja incapacitante e se relacione com o exercício do trabalho. A Lei 11430/06 trouxe importantes inovações sobre o nexo causal das doenças ocupacionais.

O artigo 21-A, da Lei 8213/91, foi acrescentado pela Lei 11430/06 e introduziu a presunção da incapacidade acidentária quando a perícia médica do INSS constatar o nexo técnico epidemiológico, isto é, a ligação entre o trabalho e o agravo, decorrente da relação entre a atividade da empresa e a entidade mórbida motivadora da incapacidade arrolada na Classificação Internacional de Doenças - CID $^{110}$.

Assim, presente o nexo técnico epidemiológico, passa a existir a presunção legal de que a doença tem natureza ocupacional.

Ressalta-se que, desde 2007, o INSS permitiu que sua perícia médica caracterizasse o nexo técnico epidemiológico, ainda que o segurado não apresente a Comunicação de Acidente de Trabalho (CAT) no momento do exame pericial. Comprovado pelos peritos o nexo técnico epidemiológico, serão devidas as prestações previdenciárias aos segurados ou dependentes.

\footnotetext{
${ }^{110} \mathrm{~A}$ constitucionalidade do nexo técnico epidemiológico é questionada por meio de Ação Direta de Inconstitucionalidade $\mathrm{n}^{\circ} 3931$ ajuizada no Supremo Tribunal Federal pela Confederação Nacional da Indústria, pendente de julgamento. A entidade alega violação direta aos artigos $7^{\circ}$, inciso XXVIII, 201 da Constituição Federal, bem como a liberdade profissional do médico (art. $5^{\circ}$, inciso XIII da CF). SUPREMO TRIBUNAL FEDERAL. Disponível em: $<$ http://www.stf.jus.br/portal/geral/verPdfPaginado.asp?id=181116\&tipo=TP\&descricao=ADI\%2F3931>. Acesso em: 19 mar. 2012.
} 
Essa presunção é relativa e pode ser elidida pela empresa. Gustavo Filipe Barbosa Garcia diz existir uma "inversão do ônus da prova" quanto à caracterização da natureza ocupacional do agravo.

O nexo técnico epidemiológico é decorrente do liame entre a atividade da empresa e a doença constante na Classificação Internacional de Doenças (CID). Por seu turno, a atividade da empresa deve se reportar ao seu ramo da atividade econômica, com observância pela Classificação Nacional de Atividade Econômica (CNAE).

$\mathrm{O}$ artigo $3^{\circ}$, inciso III, da Instrução Normativa 31/2008 do INSS indica que esse nexo técnico epidemiológico é uma das espécies do gênero nexo técnico. Dessa forma, o nexo técnico ainda está presente: a) na relação existente entre o agravo e os agentes etiológicos ou fatores de risco de natureza ocupacional, arrolados nas Listas A e B do Anexo II, do Regulamento da Previdência Social, e b) relação entre a doença e as condições em que o trabalho é executado e com ele se relaciona diretamente. Nessas hipóteses, caberá à perícia médica do INSS a caracterização técnica do acidente do trabalho, fundamentadamente, sendo obrigatório o registro e a análise do relatório médico assistente, além dos exames complementares que eventualmente acompanhem.

Portanto, o nexo técnico epidemiológico apenas é uma modalidade de nexo causal entre o trabalho e o agravo para fins de verificação da natureza ocupacional da enfermidade, considerando a atividade econômica da empresa, o que remete às condições de trabalho do empregado, pois esse labor é realizado no âmbito da empresa.

Ao irromper no mundo dos fatos o acidente do trabalho, advêm os danos à saúde do trabalhador que, por sua vez, clama por indenização. O dever indenizatório é imputado para o causador do dano, que tem a responsabilidade. Entrementes, a vítima não pode sujeitar-se à solvabilidade do responsável, pois sua força de trabalho, além de lhe conferir subsistência, é um elemento que compõe a cadeia produtiva de toda a sociedade e, por isso, o ordenamento jurídico garante-lhe o seguro.

Então, é imperioso descobrir quais foram os percursos trilhados pela responsabilidade a fim de garantir a total indenização para as vítimas de acidentes do trabalho, haja vista que eles foram o marco da mudança de paradigma da responsabilidade culposa para a sem culpa e, consequentemente, o polo irradiador dos seguros sociais. 


\subsection{Responsabilidade}

A palavra responsabilidade contém a raiz latina spondeo, que correspondia a uma forma solene que ligava o devedor ao credor nos contratos verbais. O vocábulo exprime a ideia de contraprestação, de correspondência, pois a violação da norma, da qual o agente se encontra vinculado, faz surgir a responsabilidade para ele, ou seja, nasce a obrigação de indenizar em substituição da obrigação prévia. Trata-se, então, de uma repercussão obrigacional da atividade do homem ${ }^{111}$.

A responsabilidade é um fato social e, por isso, a proibição de ofender, neminem laedere, é um dos princípios da ordem social ${ }^{112}$.

\subsubsection{Evolução da responsabilidade e a influência no seguro social}

A responsabilidade do acidente do trabalho foi ganhando contornos a partir da evolução do próprio instituto da responsabilidade civil, que teve seu ponto de partida no direito romano ${ }^{113}$.

No início, vigorava a vingança privada pela qual a vítima perseguia o autor do dano para puni-lo. Essa prática social foi apreendida pela Lei das XII Tábuas, que regulou esse comportamento ao disciplinar a composição voluntária e, em seguida, a composição obrigatória.

Pela composição voluntária, a vítima de um delito privado ${ }^{114}$ podia satisfazer seu dano pelo exercício da vingança corporal ou obter uma soma de dinheiro cujo montante era livremente fixado por ela ou aceito aquele estipulado pela lei. Cumpre registrar que esse valor monetário é uma pena privada e jamais houve uma total desvinculação dessa noção e

\footnotetext{
${ }^{111}$ DIAS, José de Aguiar. Da responsabilidade civil. 5. ed. Rio de Janeiro: Forense, 1973. v. 1, p. 8-9.

${ }^{112}$ PONTES DE MIRANDA, Francisco Cavalcanti. op. cit., t. 53, p. 14.

${ }^{113}$ Cumpre esclarecer que a evolução histórica do instituto da responsabilidade civil passará pela exigência ou não do elemento culpa.

${ }^{114}$ Delito privado é a ofensa feita à pessoa ou aos bens do indivíduo, ao passo que delito público é a violação de norma jurídica que o Estado considera de relevância social. ALVES, José Carlos Moreira. Direito romano. 6. ed. Rio de Janeiro: Forense, 1998. v. 2, p. 223.
} 
proximidade da ideia atual de indenização ${ }^{115}$. Na fase posterior, a composição passou a ser obrigatória nos limites fixados na lei.

A fase áurea do direito romano deu-se com a Lei Aquília. Ela era dividida em três capítulos: o primeiro tratava da morte de escravo e de gado, o segundo referia-se ao perdão de dívidas consentidas por um adstipulador e o terceiro considerava as lesões causadas a um escravo ou a animais e determinadas destruições ou deteriorações a qualquer coisa corpórea (damnum iniuria datum). O texto da Lei Aquília exigia que a ação fosse proposta pelo proprietário da coisa deteriorada ou destruída e também que fosse cidadão romano. $\mathrm{O}$ trabalho dos pretores mitigou esses requisitos e estendeu essa ação para titulares de direitos outros que não o de propriedade, bem como para os peregrinos.

Com o elemento culpa, houve o mesmo trabalho dos pretores. O legislador parou na constatação do prejuízo causado e estabeleceu que o dano contrário à lei implicaria no pagamento. Entretanto, verificou-se que as crianças e os loucos não tinham consciência de seu ato. Assim, lançou-se as bases da culpa pelo labor dos jurisconsultos do fim da República $^{116}$. Essa noção de culpa foi introduzida pelo caráter de pena aplicada ao causador do dano, pois a pena pressupõe culpabilidade. O direito romano não conseguiu se libertar inteiramente da concepção de pena nessa responsabilidade ${ }^{117}$.

A Idade Média, marcada por grande influência da Igreja sobre o Direito, trouxe a compensação, lastreada na piedade, ou seja, quem tem conduta contrária aos padrões cristãos não pode ser considerado honesto, ainda que respeite as leis. A culpa é um querer contra os costumes da sociedade cristã ${ }^{118}$.

Em seguida, no direito moderno, Jean Domat e Hugo Grócio aprimoraram a noção de culpa e a tornaram apenas uma causa para a responsabilidade civil. Dessa forma, a culpa deixou de ser determinante para a imputabilidade e esta somente se concretizava com o dano $^{119}$.

\footnotetext{
${ }^{115}$ A diferença entre pena e indenização será esclarecida no capítulo 3, item 3.4.2. infra.

${ }^{116}$ MAZEAUD, Jean; MAZEAUD, Leon. Traité théorique e pratique de la responsabilité civile délictuelle e contractuelle. Préface par Henri Capitant. 4. ed. Paris: Livrairie du Recueil Sirey, 1947. t. 1, p. 34.

${ }^{117}$ LIMA, Alvino. Culpa e risco. 2. ed. Atualizada por Ovídio Rocha Barros Sandoval. São Paulo: Ed. Revista dos Tribunais, 1998. p. 27.

${ }^{118}$ HIRONAKA, Giselda Maria Fernandes Novaes. Responsabilidade pressuposta. Belo Horizonte: Del Rey, 2005. p. 59.

${ }^{119}$ Id. Ibid., p. 61.
} 
Jean Domat ${ }^{120}$ influenciou o Código Civil Napoleônico que insculpiu a culpa no artigo 1382: "Todo ato do homem que causa dano a outrem, obriga aquele que agiu com culpa o dever de repará-1o ${ }^{121}$,

Esse pressuposto da culpa para gerar responsabilidade foi aplicado nos acidentes do trabalho, incumbindo ao trabalhador prová-la, uma vez que ela era a causa inicial do acidente e sua fonte originária ${ }^{122}$.

Entretanto, à medida que a vida industrial avançava com a multiplicação das máquinas, o número de acidentes do trabalho, com ferimentos graves e até o óbito, aumentava também. Dessa forma, surgiu a indagação: quem deveria ser o responsável pelas consequências desses desastres ou doenças ${ }^{123}$ ?

A responsabilidade baseada na demonstração da culpa pela vítima revelava-se insuficiente, todavia, o Brasil introduziu, tardiamente, a responsabilidade baseada na culpa no Código Civil de 1916.

Àquela época, na Europa, a teoria fundada na demonstração da culpa do empregador pela vítima cedeu lugar para a responsabilidade contratual ${ }^{124}$ que apenas inverteu o ônus da prova, isto é, exigiu-se do patrão a demonstração de que o acidente não ocorreu por sua culpa ou negligência, mas fruto de caso fortuito ou força maior, ou ainda, culpa de terceiro ou da própria vítima.

O fundamento dessa teoria é que o contrato possui, além das cláusulas expressas, as tácitas, entre elas, a relativa à promessa de segurança do empregado contra todos os riscos de acidentes ${ }^{125}$. Esse alicerce foi questionado, por Saleilles, sob o argumento de que era difícil acreditar que o empregador teria assumido, contratualmente, todos os riscos da indústria sem outras provas. Ademais, essa obrigação contratual não poderia criar um

\footnotetext{
${ }^{120}$ Jean Domat reorganizou todos os direitos em vigor em sua época de um modo sistemático, com uma base lógico-dedutiva na obra Les lois civiles dans leur ordre natural, de 1777, que influenciou os organizadores da codificação napoleônica. HIRONAKA, Giselda Maria Fernandes Novaes. op. cit., p. 62.

${ }^{121}$ No texto original: "Tout fait quelconque de l'homme, qui cause à autrui un dommage, oblige celui par la faute duquel il est arrivé à le réparer”. LEGIFRANCE. Disponível em: <http://www.legifrance.gouv.fr>. Acesso em: 23 out. 2012.

${ }^{122}$ SALEILLES, Raymond. Les accidents de travail et la responsabilité civile. Paris: Librairie Nouvelle de Droit et de Jurisprudence, 1897. p. 8.

${ }^{123}$ GONÇALVES. Luiz da Cunha. Responsabilidade civil pelos acidentes de trabalho e doenças profissionais. Coimbra: Coimbra Ed., 1939. p. 7-8.

${ }^{124}$ Nesse momento, os defensores da teoria da responsabilidade contratualista dos acidentes do trabalho foram: SAUZET, na obra De la responsabilité du patron vis-à-vis des ouvriers dans los acidentes de travail (Revue critique, 1883, p. 596 e 608) e SAINCTELETTE, precipuamente, no livro De la responsabilité et de la garantie (Bruxelles et Paris, 1884). Apud SALEILLES, Raymond. op. cit., p. 12-13.

${ }^{125}$ Id. Ibid., p. 13.
} 
tratamento diferenciado entre os trabalhadores e terceiros, vítimas de acidentes, que tinham seus danos indenizados somente se eles próprios provassem a culpa do ofensor. Por fim, um outro efeito nefasto, apontado por esse autor, seria a possibilidade de alguns empregadores aumentarem os salários em detrimento da supressão da cláusula de garantia de acidentes $^{126}$.

Desde o final do século XIX e, sobretudo, no início do século XX, caminhou-se para a fase em que a indenização integral da vítima foi a mola propulsora da responsabilidade, inclusive com a socialização dos riscos e aplicação do princípio da solidariedade.

Saleilles defendeu que a responsabilidade pelo acidente do trabalho era decorrente do próprio fato danoso e, por isso, seria uma obrigação criada por lei ${ }^{127}$. Assim, esse autor conferiu uma nova interpretação, principalmente aos artigos 1382 e 1383 do Código Napoleônico.

Inicialmente, aquele autor sustentou que o ilícito civil do artigo 1382 do Código Napoleônico é fundado sobre a materialidade do fato, ou seja, o próprio fato, em razão das circunstâncias em que é produzido e, sendo uma expressão de uma atividade perigosa, é o elemento que endossa a respectiva responsabilidade ${ }^{128}$.

Por sua vez, o artigo 1383 do Código Napoleônico, que prescreve que cada um é responsável pelo prejuízo que causou não somente pelo fato, mas também por negligência ou imprudência ${ }^{129}$. Então, segundo esse doutrinador, os riscos da atividade seriam imputados ao seu autor que responderia pelo evento danoso como causa primeira e, em seguida, perseguir-se-ia eventual negligência ou imprudência como causa secundária do prejuízo acarretado $^{130}$.

Então, bastaria a prova do fato para nascer o direito à indenização. O alicerce doutrinário de Saleilles foi o risco profissional, ou seja, aquele criado pela própria atividade empresarial lícita e, consequentemente, aquele que criou essa atividade suportará os danos provenientes ${ }^{131}$. O risco profissional é aquele inerente ao exercício da indústria e

\footnotetext{
${ }^{126}$ SALEILLES, Raymond. op. cit., p. 17-20.

${ }^{127}$ Id. Ibid., p. 61.

${ }^{128}$ Id. Ibid., p. 62.

${ }^{129}$ No texto original: "Chacun est responsable du dommage qu'il a causé non seulement par son fait, mais encore par sa négligence ou par son imprudence". LEGIFRANCE. Disponível em: $<$ http://www.legifrance.gouv.fr>. Acesso em: 23 out. 2012.

${ }^{130}$ SALEILLES, Raymond. op. cit., p. 28, 55-57.

${ }^{131}$ Id. Ibid., p. 6.
} 
capaz de expor os trabalhadores aos desastres ${ }^{132}$. Tendo o risco profissional como premissa, a responsabilidade pelos acidentes do trabalho ficaria sempre a cargo dos empregadores $^{133}$.

A Corte de Cassação francesa adotou a teoria da responsabilidade sem culpa no julgado Teffaine, de 16 de junho de 1896, em que a vítima morreu em virtude de uma explosão de uma máquina a vapor ${ }^{134}$. O proprietário da máquina foi responsabilizado, sem que pudesse demonstrar a culpa do condutor da máquina ou algum vício oculto dela.

A efervescência da indústria moderna contribuiu para o surgimento da lei francesa, de 9 de abril de 1898, que introduziu um regime de responsabilidade objetiva, sem culpa, para os acidentes do trabalho.

Louis Josserand defensor da responsabilidade objetiva, afirmou que o conceito de risco profissional não era suficiente, pois não somente a indústria geraria um risco, mas também todas as demais atividades e, por isso, a noção exata seria do risco criado ${ }^{135}$.

Entretanto, para que essa responsabilidade fosse efetiva e houvesse o pagamento das vítimas, desenvolveu-se um sistema de garantia. Como é salutar, uma das ferramentas jurídicas destinada a conferir garantia é o seguro, que pode ser privado ou social.

$\mathrm{Na}$ França, de início, havia apenas a obrigatoriedade para os patrões de criarem fundos de garantia, destinados a cobrir eventual insolvabilidade em caso de pagamento de rendas referentes à incapacidade definitiva para o trabalho. Na verdade, esses fundos de garantia não cobriam o risco de acidente do trabalho, e sim o risco de insolvabilidade do patrão em débito ${ }^{136}$. O empregador era livre para assegurar, ou não, os acidentes do trabalho. Apesar da facultatividade do seguro de acidentes do trabalho, a maioria dos empregadores estavam assegurados. Esses seguros eram livres e a cargo da iniciativa privada.

\footnotetext{
${ }^{132}$ MAGALHÃES. José Maria Vilhena de. Seguro contra acidentes de trabalho. Lisboa: Empresa Lusitana Ed., 1913. p. 81.

${ }^{133}$ Cf. MAGALHÃ̃ES. José Maria Vilhena de. op. cit., p. 84; GONÇALVES. Luiz da Cunha. op. cit., p. 10.

${ }^{134}$ COUR DE CASSATION. Rapport annuel. Rapport 2011. Troisiéme partie. Chapitre 2: Sécurité sociale. Disponível em: <http://www.courdecassation.fr/publications_cour_26/rapport_annuel_36/rapport_2011_4212/troisieme_pa rtie_etude_risque_4213/charge_risque_4247/repartition_charge_4254/chapitre_2._securite_sociale_22818. html>. Acesso em: 23 out. 2012.

${ }^{135}$ JOSSERAND, Louis. De la responsabilitè du fait des choses inanimées. Paris: A. Rosseau, 1897, p. 105106. Apud ROUAST, André; GIVORD, Maurice. op. cit., p. 21.

${ }^{136}$ ROUAST, André; GIVORD, Maurice. op. cit., p. 462-463.
} 
Somente em 1946, a lei francesa fez a integração dos acidentes do trabalho e das doenças ocupacionais no seguro obrigatório de Estado. Dessa forma, foi prevista uma cotização dos riscos sociais conforme as atividades das empresas, que substituiu a indenização dos infortúnios pelas empresas e suas seguradoras privadas.

Assim, a solidariedade em face dos riscos profissionais caminhou em direção aos primeiros seguros sociais ${ }^{137}$. O fundamento do risco profissional avançou para o risco social, haja vista a necessidade de proteção de toda a classe trabalhadora, sem qualquer tipo de exclusão.

Então, o risco, a responsabilidade e o seguro são três ideias associadas que se conjugam $^{138}$.

\subsubsection{Seguro social}

O gosto pelo risco e o desejo de segurança representam duas tendências fundamentais do espírito humano. A experiência do mundo contemporâneo revelou a gravidade dos riscos encontrados pelos indivíduos no curso da vida e, ao mesmo tempo, a aversão que as sociedades passaram a ter com eles. O progresso técnico permitiu transferir para o outro a assunção dos riscos e, assim, garantir uma maior segurança.

A razão dessa mudança comportamental foi por causas demográficas, sobretudo, pelo envelhecimento populacional. À medida que uma população jovem é marcada pelo espírito empreendedor, de entusiasmo e de adaptação às mudanças bruscas de vida, a sabedoria e a experiência de uma população mais idosa é acompanhada de um sentimento de insegurança diante do futuro.

Essa nova mentalidade proporcionou que todos os países envidassem esforços para construir planos de seguridade social, haja vista o caráter associativo do ser humano. Como é cediço, para satisfazer as suas necessidades crescentes, os homens são impelidos para a vida em sociedade. Após as conquistas dos gêneros básicos, as pessoas são lançadas para expansão e desenvolvimento da vida social. Dessa forma, a sociabilidade vai estendendo sua ação e, consequentemente, as complexas relações sociais trazem aos seres humanos a consciência de sua mútua dependência.

\footnotetext{
${ }^{137}$ SUPIOT, Alain. Le droit du travail. 3. ed. Paris: Presses Universitaires de France, 2008. p. 17.

${ }^{138}$ MAGALHÃES. José Maria Vilhena de. op. cit., p. 80.
} 
Enfim, esses planos de seguro social são integrados pela solidariedade, que é o cuidado de uns com a condição social e econômica de outros ${ }^{139}$.

A Alemanha desencadeou os sistemas de seguro social obrigatório desde 1883, pelo chanceler Bismark, por meio do seguro-doença-maternidade, para os operários da indústria e do comércio, nos casos de enfermidades e de nascimentos de filhos ${ }^{140}$. Em 6 de julho de 1884, foi criado o seguro acidente do trabalho que cobria todos os riscos do trabalho, salvo aqueles infortúnios ocorridos por ato intencional e deliberado da vítima. A gestão ficou a cargo de associações patronais que formulariam o seu plano de seguros e prevenção dos infortúnios ${ }^{141}$.

Todavia, o grande triunfo da seguridade social, nos moldes atuais, deu-se com o plano Beveridge, na Inglaterra, durante o período de destruição da Segunda Guerra Mundial.

O governo inglês nomeou uma Comissão Interdepartamental de Seguro Social e Serviços Anexos, presidida por Sr. Willian Henry Beveridge, que fora autodenominada liberal. O plano foi publicado em dezembro de 1942; contudo, foi rejeitado pelo Partido Conservador e por Churchill, sob o argumento de que estava afastado da realidade. Mais tarde, entre 1944 e 1949, com a ascensão do Partido Trabalhista inglês, o plano foi implementado dentro de uma concepção de Welfare State que caminhava em direção a um socialismo reformado. Dessa forma, apesar de o plano ser feito por um liberal para liberais, ele foi usado por socialistas rumo ao socialismo e apoderado pelo Estado de Bem-Estar Social que fez as adaptações necessárias ${ }^{142}$.

As características fundamentais do plano Beveridge foram: a) os sistemas de seguros públicos deveriam ser unificados e administrados por um Ministério instituído para tal fim; b) esses seguros públicos deveriam ter caráter de instituição de abrangência nacional e com contribuição uniforme e c) o seguro de Estado deveria ser administrado pelo poder público com o objetivo de manter elevados os níveis de emprego ${ }^{143}$.

\footnotetext{
${ }^{139}$ SOUTO MAIOR, Jorge Luiz; CORREIA, Marcus Orione Gonçalves. O que é direito social? In: CORREIA, Marcus Orione Gonçalves (Org.). Curso de direito do trabalho: teoria geral do direito do trabalho. São Paulo: LTr, 2007. v. 1, p. 23.

${ }^{140}$ CORREIA, Marcus Orione Gonçalves; CORREIA, Érica Paula Barcha. Curso de direito da seguridade social. São Paulo, 2001. p. 5.

${ }^{141}$ CARDONE, Marly A. Seguro social e contrato de trabalho. São Paulo: Saraiva, 1973. p. 9-10.

${ }^{142}$ CORREIA, Marcus Orione Gonçalves; CORREIA, Érica Paula Barcha. op. cit., p. 10.

${ }^{143}$ BARROS, A. B. Buys de. O seguro social no direito brasileiro. Rio de Janeiro: Max Limonad, 1944. p. 227. (Coleção de Direito do Trabalho organizada por Dorval de Lacerda e Evaristo de Morais Filho, v. 8).
} 
O plano cobria todos os cidadãos, independentemente do limite de renda. Entretanto, ele se focalizou nos diferentes modos de vida e abrangeu as necessidades humanas básicas e previsíveis. Beverigde apontou que a população podia ser dividida em seis classes, das quais, quatro eram integradas por pessoas da faixa etária para trabalhar e as outras duas referiam-se aos indivíduos com idade abaixo ou acima desse limite. As classes eram, a saber: a) os empregados sujeitos a contrato de trabalho; b) outras ocupações remuneradas, como empregadores, comerciantes e profissionais liberais; c) donas de casa (mulher casada em idade de trabalhar); d) as pessoas em idade de trabalhar sem ocupação remunerada; d) abaixo do limite mínimo de idade para laborar e e) aposentados com idade acima do limite para trabalhar ${ }^{144}$.

Como decorrência lógica, essas pessoas eram tuteladas na medida em que estavam sujeitas a alguns dos riscos sociais, tais como: desemprego, perda dos ganhos dos ocupantes de funções remuneradas diferentes da relação de emprego, doenças, velhice, morte, infância, necessidades da mulher casada, como a maternidade e a viuvez.

Dessa forma, a noção de seguridade social está intimamente ligada a dos riscos sociais. De acordo com Paul Durand, risco social é um acontecimento futuro e incerto, cuja realização não depende exclusivamente da vontade do segurado ${ }^{145}$. A incerteza do risco social apresenta-se sob os seguintes aspectos: a) sobre sua própria ocorrência, como o risco de doença e da velhice; b) sobre a data do evento que pode ser futuro e certo, como a morte. Esse risco é, na maioria das vezes, um acontecimento indesejável, tal como a doença, a morte. Por outro lado, esse mesmo risco pode se referir a um acontecimento bom, como o casamento e o nascimento de uma criança. Devido a essas ponderações, Marly Cardone utiliza-se da expressão contingência humana ao invés de risco social, tendo-se como fundamento a diminuição da renda ou um aumento das despesas ${ }^{146}$.

Dentro do instituto da seguridade social do Estado, a proteção legal do trabalhador manifesta-se pela saúde, assistência e previdência. Beveridge já previa em seu plano que os casos não cobertos pela previdência seriam matéria de assistência nacional. Outrossim, ele fixou os parâmetros para que os tratamentos médicos fossem providos a todos os cidadãos por um serviço organizado nacionalmente por departamentos de saúde, e estabeleceu um

\footnotetext{
${ }^{144}$ BEVERIDGE, William. Social insurance and allied services: report by Sr. William Beveridge. New York: The Macmillan Company, 1942. p. 9-11.

${ }^{145}$ DURAND, Paul. La politique contemporaine de sécurité sociale. Paris: Dalloz, 1953. p. 14.

${ }^{146}$ CARDONE, Marly A. op. cit., p. 14-15.
} 
tratamento de reabilitação para todas as pessoas que pudessem se beneficiar com esse serviço $^{147}$.

A assistência é a ação do Estado, por autarquias destinadas a tal fim, no sentido de proteger econômica e fisicamente os trabalhadores e a classe pobre no momento que necessitarem dessa proteção, seja na relação de emprego, seja no desenvolvimento de sua atividade produtiva ou, até mesmo, na sua condição de membro do povo de um dado território $^{148}$.

A saúde é um direito de todos e dever do Estado, que deve garanti-la por políticas sociais e econômicas que visem à redução do risco de doença e de outros agravos. As ações e serviços de saúde são de relevância pública e, por isso, estão sujeitos à regulamentação, à fiscalização e ao controle do Poder Público que os executa diretamente ou por pessoas de direito privado ${ }^{149}$. Dessa forma, a saúde pode ser considerada como uma modalidade lato sensu de assistência, uma vez que não tem o caráter contributivo ${ }^{150}$.

Por sua vez, previdência é um complexo de tarefas destinadas não apenas a fornecer o reduzido salário do trabalhador, quando este precisar de meios de cura, como também de preparar um futuro para si e os seus; trata-se de descanso na idade avançada ou na inatividade por invalidez, com a aposentadoria ou com a concessão de renda para a família, com a pensão em caso de sua morte ${ }^{151}$. Entretanto, partindo-se de uma definição mais ampla, Celso Barroso Leite diz que previdência social é o conjunto de medidas destinadas a amparar as classes trabalhadoras e outros grupos em emergências decorrentes da cessação do salário ou de necessidades especiais ${ }^{152}$.

Essa previdência pode ser subdividida em: livre e obrigatória. Enquanto a livre é resultante da atividade particular e faculta ao indivíduo a sua adesão ou não, a obrigatória é estatal e vincula a classe trabalhadora. Marly Cardone pondera que a previdência social atua pelo seguro social, pois a relação jurídica se forma a priori, ou seja, antes do momento da concessão dos benefícios ${ }^{153}$. A vontade manifestada para o vínculo de

\footnotetext{
${ }^{147}$ BEVERIDGE, William. op. cit., p. 11.

${ }^{148}$ BARROS, A. B. Buys de. op. cit., p. 15.

${ }^{149}$ SILVA, José Afonso da. Curso de direito constitucional positive, cit., 23. ed., p. 811.

${ }^{150}$ PICARELLI, Márcia Flávia Santini. Do seguro social à seguridade social: desafios e paradoxos. Revista de Previdência Social, São Paulo, v. 16, n. 145, p. 1091-1097, dez. 1992.

${ }^{151}$ BARROS, A. B. Buys de. op. cit., p. 12.

${ }^{152}$ LEITE, Celso Barroso. A proteção social no Brasil. São Paulo: Saraiva, 1972. p. 17-18.

${ }^{153}$ CARDONE, Marly A. op. cit., p. 21-23.
} 
emprego já contém a manifestação de vontade para o seguro social, com a imposição do dever de contratá-1o ${ }^{154}$.

A finalidade do seguro social é socorrer o segurado naquelas situações em que a capacidade laborativa foi reduzida ou houve a diminuição de ganho, a fim de se evitar a queda em estado de indigência ${ }^{155}$. Por esse motivo, as prestações são continuadas e periódicas diante das contingências humanas que acarretam impossibilidade de trabalho ou de ganho, isto é, os valores correspondem a um mínimo vital para suprir a falta de remuneração e não existe equivalência entre o dano e o montante a ser ressarcido, como ocorre na indenização decorrente do direito civil ${ }^{156}$.

Dessa forma, pode-se pontuar como uma das características do seguro social sua obrigatoriedade proveniente da lei. Essa obrigatoriedade abrange não apenas os segurados, mas também o órgão segurador que não tem liberdade de escolher as pessoas com as quais manterá a relação jurídica assecuratória, uma vez que essa relação nasce quando preenchidas as condições objetivas previstas em lei. Em decorrência, todas as normas que incidem na relação jurídica são derivadas da lei e não são permitidos pactos mais favoráveis. Por fim, esse seguro social constitui um instituto de direito público e o Estado tem interesse em administrá-lo.

Dessa forma, conforme Marly Cardone, seguro social é um modo obrigatório de indenização dos efeitos provenientes da verificação dos riscos normais da vida, que trazem aumento de despesas, resultando da lei o surgimento da relação jurídica e o respectivo regramento, devido ao desenvolvimento de atividade remunerada ${ }^{157}$.

No mesmo sentido, Buys de Barros diz que seguro social é um instituto jurídico que tem como finalidade não só evitar a perda econômica ou biológica, que advém da execução do trabalho, como de fazê-la desaparecer pelos instrumentos que oferece de indenização dos $\operatorname{riscos}^{158}$.

Assim, seguro social é um instituto jurídico disciplinado somente pela lei, que ampara aqueles que exercem ou que exerceram alguma atividade remunerada, diante de situações de perda e/ou redução de capacidade de ganho ou de aumento de despesa, com o escopo de manter a solidariedade social.

\footnotetext{
${ }^{154}$ PONTES DE MIRANDA, Francisco Cavalcanti. op. cit., t. 46, p. 96.

${ }^{155}$ CARDONE, Marly A. op. cit., p. 12.

${ }^{156}$ Id. Ibid., p. 16-17.

${ }^{157}$ Id. Ibid., p. 27.

${ }^{158}$ BARROS, A. B. Buys de. op. cit., p. 6.
} 


\subsubsection{Seguro social e o acidente do trabalho no Brasil}

Inicialmente, não havia uma legislação específica sobre o tema no Brasil.

O Código Comercial do Império determinava que os acidentes imprevistos e inculpados, que impediam aos prepostos o exercício de suas funções, não interromperiam o vencimento do seu salário, contanto que a inabilitação não ultrapassasse 3 (três) meses contínuos. Além dessa regra geral, a legislação imperial era pontual e vinculada ao tipo de atividade, como para os tripulantes de navio. Dessa maneira, esse mesmo diploma regrava que se qualquer indivíduo da tripulação adoecesse durante a viagem em serviço do navio, receberia a soldada ajustada e o curativo seria por conta da embarcação. Entretanto, se a enfermidade fosse adquirida fora do serviço do navio, cessaria o vencimento da soldada enquanto durasse a doença e a despesa do curativo seria por conta das soldadas vencidas e, se essas fossem insuficientes, pelos bens do enfermo ou pelas soldadas que se venceriam.

Somente com o Decreto Legislativo 3724, de 15 de janeiro de 1919, é que surgiu a primeira lei acidentária brasileira ${ }^{159}$. Essa lei trazia o conceito de acidente típico e de moléstia profissional para alguns setores da economia, além de impingir a responsabilidade do empregador pelo pagamento das indenizações, exceto nos casos de força maior, dolo da própria vítima ou de estranho.

A Constituição de 1934 foi a primeira a mencionar a proteção do acidente do trabalho como prestação previdenciária e, por conseguinte, como um seguro social mediante contribuição igual da União, do empregador e do empregado. O artigo 121 prescreveu que a legislação do trabalho observaria, dentre outros preceitos que melhorassem as condições sociais do trabalhador, a instituição de previdência nos casos de acidentes do trabalho. A legislação infraconstitucional dessa época (Decreto 24637/34) incluiu as doenças profissionais atípicas no conceito de acidente do trabalho, além de estender a proteção a outros setores da economia, como os comerciários e os domésticos. Para conferir maior proteção aos empregados, esse Decreto determinou a contratação de um seguro privado ou a realização de depósitos em dinheiro no Banco do Brasil ou na Caixa Econômica Federal para garantir o pagamento das indenizações e benefícios acidentários aos herdeiros.

${ }^{159}$ MELO, Raimundo Simão de. op. cit., p. 203. 
A Constituição de 1937, por sua vez, deixou ao legislador ordinário a tarefa de conceituar o seguro social, uma vez que garantiu ao trabalhador apenas a instituição de seguro em casos de acidentes do trabalho. Então, o próximo passo foi dado com o Decreto 7036/44, que aumentou o conceito de acidente do trabalho para incorporar a teoria das concausas e o acidente in itinere. Ademais, foi criado o monopólio estatal do seguro obrigatório garantidor das indenizações devidas aos trabalhadores.

Dessa forma, o Estado, ao editar leis de seguro social, se preocupa com a coletividade, pois não almeja que os acidentados fiquem marginalizados. A solidariedade impera no regime de seguro social, uma vez que o segurado que sofreu o acidente sempre recebe o seu benefício, ainda que esteja inadimplente no pagamento da contribuição social para financiar esse seguro ou que a quitação não tenha se efetivado na ocasião do sinistro, devido à desnecessidade de carência.

O grande avanço desse Decreto 7036/44 foi a previsão de cumulação da indenização acidentária com a de direito comum, desde que o acidente decorresse de dolo do empregador ou de seu preposto. Até então, acidente do trabalho fora tratado como um fato específico, regulado por lei própria e a indenização prevista era plena e irrevogável para a indenização dos danos sofridos pela vítima, com a dispensa dos postulados de Direito Civil. Cumpre ressaltar, no entanto, que a prestação devida pelo órgão previdenciário oficial era limitada à substituição ou a complementação do salário, a fim de amparar o acidentado e sua família. O artigo 31, do Decreto 7036/44, introduziu uma exceção a regra geral ao admitir que a vítima ou seus dependentes pudessem ingressar com o pleito da indenização do direito comum quando houvesse dolo do empregador. Em constante evolução, o Supremo Tribunal Federal editou a súmula 229 que prescrevia que a indenização acidentária não excluía a do direito comum, em caso de dolo ou culpa grave do empregador. A culpa grave foi equiparada ao dolo para fins de indenização ${ }^{160}$.

A Constituição Federal de 1946 previu a obrigatoriedade da instituição de seguro pelo empregador contra acidentes do trabalho, mas o retirou da noção de seguro social. Essa mesma ideia foi mantida na Constituição de 1967, que separou o seguro obrigatório pelo empregador contra acidentes do trabalho da previdência social. Em ambos os textos constitucionais, o seguro contra acidentes do trabalho foi instituído como direito do

\footnotetext{
${ }^{160}$ As diferenças entre dolo e os graus de culpa serão estudadas no capítulo 3, item 3.3.3. infra.
} 
trabalhador, sob a responsabilidade do empregador ${ }^{161}$. Essa redação constitucional refletiu na legislação ordinária, pois o Decreto 293/67 terminou com o monopólio estatal do seguro obrigatório, criando uma concorrência entre as seguradoras privadas. Esse decreto teve uma vida efêmera e foi substituído pela Lei 5316/67, que restaurou os dispositivos do Decreto-lei 7036/44, dentre eles, o monopólio estatal do seguro de acidentes do trabalho. Essa lei provocou grande controvérsia sob a possibilidade de o seguro de acidentes do trabalho integrar a previdência social, uma vez que a Constituição de 1967 não esboçou dessa maneira.

Russomano ponderou que a Lei 5316/67 fez a integração do seguro contra acidentes do trabalho no sistema da previdência social brasileira, mas trouxe efeitos problemáticos na conjuntura do país da época. Esse doutrinador explica que não houve revogação automática e imediata das normas anteriores sobre seguros contra acidentes e dos cálculos de indenizações devidas aos acidentados e/ou seus dependentes; todavia, esse diploma legal manteve tais normas em caráter parcial e transitório ${ }^{162}$.

Por outro lado, segundo Fernando Figueiredo de Abranches, a lei ordinária integrou o seguro contra acidentes do trabalho na autarquia previdenciária, retirando-o das seguradoras particulares. Àquela época, o Instituto Nacional de Previdência Social (INPS) passou a ser apenas agente executor. Por essa leitura, o legislador poderia reverter o seguro contra acidentes do trabalho às seguradoras privadas ${ }^{163}$.

Já a Constituição de 1969 retomou a tradição da Constituição de 1934 e assegurou aos trabalhadores seguro social contra acidentes do trabalho mediante contribuição da União, do empregador e do empregado, ou seja, tripartida. Essa integração do seguro social ao sistema da previdência trouxe implicações práticas ao mundo do trabalho, pois, conforme já mencionado, a eventual falta de recolhimento das contribuições não retira dos empregados o direito de pleitear as prestações da autarquia previdenciária. Posteriormente, a Lei 6195/74 estabeleceu que o seguro de acidente do trabalho rural ficaria a cargo do Fundo de Assistência ao Trabalhador Rural (FUNRURAL), fato que representou uma grande proteção aos trabalhadores rurais. Finalmente, a Lei 6367/76 inovou ao prever a doença proveniente da contaminação acidental do pessoal de área médica como acidente

\footnotetext{
${ }^{161}$ ABRANCHES, Fernando Figueiredo de. Do seguro mercantilista de acidentes do trabalho ao seguro social. São Paulo: Sugestões Literárias, 1974. p. 17.

${ }^{162}$ RUSSOMANO, Mozart Victor. op. cit., p. 387.

${ }^{163}$ ABRANCHES, Fernando Figueiredo de. op. cit., p. 18.
} 
do trabalho. Entretanto, essa lei não previu a possibilidade de indenização de direito comum.

Atualmente, a Constituição de 1988 integrou o seguro de acidente do trabalho à previdência social que é organizada em caráter contributivo e de filiação obrigatória a partir de uma interpretação sistemática ${ }^{164}$.

O inciso XXVIII do artigo $7^{\circ}$ da Constituição Federal previu um seguro contra acidentes do trabalho a cargo do empregador, isto é, um direito social do trabalhador com uma das faces previdenciária, haja vista que outros incisos desse mesmo artigo são caracterizados pela solidariedade social, como a aposentadoria e o seguro-desemprego. Ademais, a norma não exige exclusividade do custeio do seguro, que poderá ser feito também pelos trabalhadores e pelo próprio Estado. Acrescente-se, ainda, que, dentre os eventos que serão cobertos pela previdência social (artigo 201, inciso I, da Constituição), destacam-se: a doença, a invalidez e a morte, que podem ser o acidente do trabalho em si (doença ocupacional) ou, simplesmente, manifestações dos seus efeitos. Assim, infere-se que se trata de seguro social.

Todavia, o seguro de acidente do trabalho não é monopólio estatal, haja vista que o artigo 201, parágrafo 10, da Constituição, ao fixar que a lei disciplinará a cobertura do risco de acidente do trabalho, a ser atendida concorrentemente pelo regime geral de previdência social e pelo setor privado, corrobora a possibilidade de cumulação da indenização acidentária com a de direito comum.

Nos dias de hoje, a Lei 8213/91 assegura o pagamento de benefícios para os segurados acidentados, bem como para os seus dependentes reconhecidos pela previdência social. Em razão de a previdência ser estruturada sob o modelo contributivo, analisar-se-á o financiamento do seguro social brasileiro de acidente do trabalho.

\subsubsection{Financiamento do seguro social para o acidente do trabalho}

A previdência social brasileira é organizada sob a forma de regime geral, de caráter contributivo misto (com financiamento de trabalhadores, tomadores de serviços e

\footnotetext{
${ }^{164}$ Interpretação sistemática é um dos métodos para se determinar o sentido e alcance de uma norma que se considera a unidade do sistema jurídico. Dessa forma, o preceito deve ser analisado em seu contexto e em sua concatenação imediata. FERRAZ JÚNIOR, Tércio Sampaio. op. cit., p. 288-289.
} 
poder público) e de filiação obrigatória, observados critérios que preservem o equilíbrio financeiro e atuarial e abrange, dentre outros, o seguro social em eventos de doença, invalidez, morte e idade avançada. Como é cediço, a doença e a morte podem ser efeitos dos acidentes do trabalho. O regime geral é administrado pela União e sua atribuição é descentralizada à autarquia previdenciária, qual seja, o Instituto Nacional de Seguro Social (INSS).

A Constituição Federal estipulou a existência de um seguro social a cargo do empregador, que transfere para o INSS a tarefa de efetuar a reparação na hipótese de acidente do trabalho, independentemente de qualquer decisão sobre a culpa, com fundamento no próprio no artigo $7^{\circ}$, inciso XXVIII, e também no artigo 195, que regula o custeio das contribuições sociais.

Como contrapartida à concessão dos benefícios previdenciários em caso de acidentes do trabalho, a legislação nacional prevê o recolhimento obrigatório do seguro de acidente do trabalho (SAT) a cargo exclusivo da empresa, por meio de uma contribuição adicional, com percentuais variáveis de acordo com os riscos empresariais. Veja-se.

O artigo 22, inciso II, da Lei 8212/91 determina que, para o financiamento da aposentadoria especial ${ }^{165}$ e dos benefícios concedidos em razão do grau de incidência de incapacidade laborativa decorrente dos riscos ambientais do trabalho (RAT), o empregador contribui sobre o total das remunerações pagas ou creditadas no decorrer do mês aos segurados empregados e aos trabalhadores avulsos, nas alíquotas variáveis entre $1 \%, 2 \%$ e $3 \%$, conforme o risco de acidente do trabalho na atividade preponderante da empresa seja considerado leve, médio ou grave, respectivamente.

A Lei 10666/03 permitiu que essas alíquotas fossem reduzidas em até 50\% ou aumentadas em até $100 \%$, considerando o desempenho da empresa em relação a sua atividade econômica preponderante, apurado em conformidade com os resultados obtidos a partir dos índices de frequência, de gravidade e de custo, calculados conforme metodologia aprovada pelo Conselho Nacional da Previdência Social (CNPS).

Essa matéria foi regulamentada pelo Decreto 6042/07, que instituiu o fator acidentário de prevenção (FAP) no artigo 202-A do Regulamento Geral da Previdência

\footnotetext{
${ }^{165}$ Ressalta-se que aposentadoria especial é um benefício previdenciário concedido, uma vez cumpridos os prazos de carência, ao segurado que tiver trabalhado sujeito a condições especiais que prejudiquem a saúde ou a integridade física, durante 15 (quinze), 20 (vinte) ou 25 (vinte e cinco) anos (artigo 57 da Lei $8.213 / 91)$.
} 
Social. Esse fator acidentário de prevenção consiste em um multiplicador variável num intervalo contínuo entre cinco décimos $(0,5)$ a dois inteiros $(2,00)$, a ser aplicado à respectiva alíquota da contribuição relativa ao risco acidentário de trabalho ${ }^{166}$.

Para se obter esse multiplicador variável (FAP), o Conselho Nacional da Previdência Social editou a Resolução $1308^{167}$, de 27 de maio de 2009, que identificou a sua metodologia. Inicialmente, para os cálculos da frequência, da gravidade e do custo serão considerados os registros de todas as comunicações de acidentes do trabalho (CAT) e dos benefícios de natureza acidentária, os quais serão computados pelo cadastro nacional de pessoa jurídica (CNPJ) ao qual o trabalhador estava vinculado no momento do acidente ou ao qual o agravo esteja diretamente vinculado. Para se obter os índices de frequência, de gravidade e de custo são atribuídos percentuais de ordem para as empresas do setor para cada um dos índices. A empresa com menor frequência de acidentes recebe o menor percentual, ao passo que aquela com maior frequência recebe $100 \%$. Esse percentual é obtido pelos dados ordenados de modo ascendente.

Desses percentuais de ordem, é criado um índice composto, atribuindo ponderações aos percentis de ordem de cada índice. Esse critério da ponderação procura conferir maior peso para a gravidade $(0,50)$, de modo que os eventos morte e invalidez tenham maior influência do índice composto. Em seguida, a frequência recebe o segundo maior peso $(0,35)$ e, finalmente, ao custo é atribuído o menor peso $(0,15)^{168}$.

Para fins de enquadramento, considera-se a relação de atividades preponderantes e os respectivos graus de risco constante do Anexo V, do Regulamento Geral da Previdência Social, que se baseou na classificação nacional de atividades econômicas (CNAE). Esse enquadramento no determinado grau de risco é de responsabilidade da empresa com base na sua atividade econômica preponderante e tem periodicidade mensal, incumbindo ao fisco rever esse enquadramento a qualquer tempo. O Superior Tribunal de Justiça (STJ) considera que o enquadramento da atividade preponderante deve ser por estabelecimento da empresa, inclusive quando possuir um único $\mathrm{CNPJ}^{169}$.

\footnotetext{
${ }^{166}$ PREVIDÊNCIA SOCIAL. Regulamento da Previdência Social. Decreto 3.048/99. Disponível em: <http://www81.dataprev.gov.br/sislex/paginas/23/1999/3048.htm>. Acesso em: 27 maio 2012.

${ }^{167}$ PREVIDÊNCIA SOCIAL. Resolução 1.308/09, do CNPS, teve seu anexo substituído pela Resolução 1.316, de 2010 do CNPS. Disponível em: <http://www81.dataprev.gov.br/sislex/paginas/72/mpscnps/2010/1316.htm>. Acesso em: 27 maio 2012.

${ }^{168}$ CASTRO, Carlos Alberto Pereira de; LAZZARI, João Batista. Manual de direito previdenciário. 12. ed. Florianópolis: Conceito Editorial, 2010. p. 294.

${ }^{169}$ A súmula 351 do STJ corrobora esse posicionamento ao determinar, in verbis: "A alíquota de contribuição para o seguro de acidente do trabalho - SAT - é aferida pelo grau de risco desenvolvido por cada empresa,
} 
Infere-se, então, que a metodologia aplicada objetiva bonificar aqueles empregadores que tenham feito um trabalho intenso nas melhorias ambientais e, por conseguinte, tenham apresentado os menores índices de acidentalidade nos últimos 12 meses. Por outro lado, esse modelo pune aquelas empresas que descuidaram de seu ambiente laboral e tiverem índices de acidentalidade superiores à média do setor econômico em que estão inseridas ${ }^{170}$. Assim, modelo brasileiro de seguro social está em consonância com prevenção dos danos.

Essa responsabilidade é baseada na teoria do risco social e, consequentemente, nem as causas de exclusão do nexo causal (culpa exclusiva da vítima, fato de terceiro, caso fortuito ou força maior) são suficientes para afastar o direito do empregado ao benefício previdenciário. Somente se admite o dolo do segurado como causa de exclusão da responsabilidade do INSS. Todavia, o INSS tem direito de ação em face do empregador negligente quanto às normas ambientais para reaver os dispêndios nesses benefícios. Essa postura alinha-se à tendência de prevenção dos próprios acidentes do trabalho.

\subsubsection{Direito de regresso do Instituto Nacional do Seguro Social}

O artigo 120 da Lei 8213/91 prevê que a previdência social disporá de ação regressiva em face dos responsáveis pelo acidente do trabalho que agiram negligentemente quanto às normas de segurança e de saúde do trabalho indicadas para a proteção individual e coletiva dos segurados. Dessa forma, o empregador não se exime de indenizar a previdência pelo fato de já ter arcado com a contribuição social do seguro de acidente do trabalho, pois o recolhimento desse tributo não confere espaço a atitudes negligentes.

O Estado resguarda a subsistência do trabalhador e de seus dependentes, mas possui o direito de exigir do culpado pelo dano a indenização decorrente dos gastos com os benefícios acidentários. Conforme Castro e Lazzari, esse mecanismo é uma medida justa, pois a solidariedade social não pode abrigar condutas reprováveis como a do empregador que não fornece condições de trabalho indene de riscos de acidentes ${ }^{171}$. No mesmo sentido,

individualizada pelo seu CNPJ, ou pelo grau de risco da atividade preponderante quando houver apenas um registro". SUPERIOR TRIBUNAL DE JUSTIÇA. Disponível em: $<$ http://www.stj.jus.br/SCON/sumulas/toc.jsp?tipo_visualizacao=null\&livre=s\%FAmula+351\&b=SUMU>. Acesso em: 27 maio 2012.

${ }^{170}$ CASTRO, Carlos Alberto Pereira de; LAZZARI, João Batista. op. cit., 12. ed., p. 294.

${ }^{171}$ Id. Ibid., p. 597. 
Daniel Pulino afirma que os danos gerados ao INSS a partir desses acidentes não podem e não devem ser suportados por toda a sociedade, na medida em que, no risco repartido entre os membros da coletividade (risco social), não se admite a inclusão de atitude ilícita da empresa que não cumpre as normas protetivas da higidez do ambiente do trabalho ${ }^{172}$.

Esse regresso praticado pelo INSS tem natureza jurídica de demanda civil indenizatória por ato ilícito e, por isso, os pressupostos são: ação ou omissão daquele responsável de se evitar o resultado que, se por ventura ocorrer, gera um prejuízo ao erário público, isto é, o pagamento pela autarquia previdenciária dos benefícios concedidos em razão do infortúnio trabalhista que foi desencadeado pela negligência empresarial.

Em razão de o ressarcimento buscado pelo INSS ter natureza de direito civil, e não de tributo, é incompatível o argumento de que essa conduta feriria o artigo $195, \S 4^{\circ}$, da Constituição Federal, que fixa que a instituição de novas fontes de custeio para a seguridade social será somente por lei complementar.

No tocante à lei de regência aplicável, vige aquela no momento do acidente. Diante desse dogma, poder-se-ia indagar se essa demanda regressiva seria cabível para os acidentes do trabalho ocorridos antes de 9 de dezembro de 1991, ou seja, antes do início da vigência do novo plano de benefícios da previdência social ${ }^{173}$, que previu expressamente o direito de regresso da autarquia previdenciária.

Como é cediço, mesmo antes da vigência do artigo 120 da Lei 8213/91, o direito de regresso era possível, sob o fundamento jurídico da responsabilidade civil decorrente de ato ilícito com previsão nos artigos 159 e 1524 do Código Civil de 1916, vigente outrora. Assim, aquele que por ação ou omissão voluntária, negligência ou imprudência, violasse direito ou causasse prejuízo a outrem, ficaria obrigado a indenizá-lo. Outrossim, a lei civil aduzia que aquele que ressarcisse o dano causado por outrem, se este não fosse descendente seu, poderia reaver daquele por quem pagou, aquilo que houvesse pago.

Então, infere-se que a autarquia previdenciária podia se ressarcir de todos os danos que sofreu em decorrência de ação ou omissão negligente das empresas no tocante ao meio ambiente do trabalho, ainda que anterior à órbita de vigência do artigo 120 da Lei 8213/91, que regulou expressamente o direito de regresso nessas hipóteses.

\footnotetext{
${ }^{172}$ PULINO, Daniel. Acidente do Trabalho. Ação regressiva contra as empresas negligentes quanto à segurança e à higiene do trabalho. Revista de Previdencia Social, Sao Paulo, v. 20, n. 182, p. 7, jan. 1996.

${ }^{173}$ Apesar de a Lei 8213/91 ter sido publicada em 25 de julho de 1991, o Superior Tribunal de Justiça firmou entendimento de que ela só passou a vigorar com a publicação do Decreto 357, de 9 de dezembro de 1991.
} 
Entretanto, o exercício desse direito de regresso é limitado no tempo em virtude do instituto da prescrição. A prescrição é a extinção de uma ação ajuizável, em virtude da inércia de seu titular durante um certo lapso de tempo, na ausência de causas preclusivas em seu curso $^{174}$. Para a determinação de qual a regra prescricional é aplicável, faz-se necessário fixar o objeto das demandas regressivas.

O objeto das demandas regressivas é o pagamento de uma indenização pelo empregador negligente em razão dos danos que o INSS sofreu pela concessão dos benefícios acidentários. Por conseguinte, a prescrição aplicável é a prevista na legislação civil. $\mathrm{O}$ fato de o direito de ação ser de titularidade de ente público não desnatura o objeto da demanda. Esse posicionamento é embasado em Hely Lopes Meireles, que argumenta que a prescrição das ações da Fazenda Pública contra o particular é a comum da lei civil ou da comercial, de acordo com a natureza do ato a ser questionado ${ }^{175}$.

O novo Código Civil de 2002 tornou essa contagem do prazo complexa. A regra de transição da lei civil estabeleceu que serão os da lei anterior, os prazos, quando reduzidos pelo novo Código Civil, e se, na data de entrada em vigor, já houver transcorrido mais da metade do tempo estabelecido na lei revogada. Na medida em que o artigo 177, caput, do Código Civil de 1916 fixou o prazo prescricional de 20 (vinte) anos para o exercício do direito de pleitear a indenização de ilícito civil, o artigo 206, parágrafo $3^{\circ}$, do Código Civil de 2002 reduziu esse lapso temporal para 3 (três) anos.

Em ato contínuo, para o estabelecimento desses limites temporais, deve-se inquirir se, na data de entrada em vigor do novo Código Civil, ou seja, em 11 de janeiro de 2003, já teria transcorrido mais da metade do prazo prescricional previsto no Código Civil de 1916, contado da data em que o INSS começou a conceder o benefício acidentário. Caso tenha escoado mais da metade do prazo prescricional previsto no Código Civil de 1916, incidirá esse diploma normativo, contado o prazo a partir do fato ilícito. Caso contrário, será aplicado o prazo previsto na nova legislação civil, tendo-se como marco inicial a entrada em vigor dessa nova lei, pois se o prazo fosse contado a partir do fato, estar-se-ia conferindo retroatividade ao novo Código Civil para atingir fatos anteriores a sua vigência,

\footnotetext{
${ }^{174}$ LEAL, Antonio Luiz da Câmara. Da prescrição e da decadência. Rio de Janeiro: Forense, [s.d.]. p. 26.

${ }^{175}$ MEIRELLES, Hely Lopes. Direito administrativo brasileiro. 15. ed. São Paulo: Ed. Revista dos Tribunais, 1990. p. 621.
} 
circunstância que contraria a Lei de Introdução às Normas do Direito Brasileiro (DecretoLei $4657 / 42)^{176}$.

Ressalva-se a existência de entendimento contrário, defendido por Fernando Maciel, quanto à aplicação do prazo prescricional previsto no Código Civil. Por conseguinte, ele pugna pela incidência do prazo prescricional de 5 (cinco) anos previsto no artigo $1^{\circ}$ do Decreto 20910/32. Esse dispositivo disciplina o lapso temporal de 5 (cinco) anos para perda da pretensão em face da Fazenda Pública. Dessa maneira, a prescrição quinquenal deve ser usada nas demandas regressivas acidentárias em obediência ao princípio da isonomia, pois se esse é o prazo aplicado nas pretensões deduzidas pelos administrados em face da Fazenda Pública, nas relações processuais em que os polos são invertidos, o idêntico decurso de tempo deve ser seguido ${ }^{177}$. Celso Antônio Bandeira de Mello corrobora que não haveria razão suficiente para distinguir entre Administração e administrados no tocante ao prazo, ao fim do qual se extinguiria o direito de reciprocamente se exercitarem o direito de ação ${ }^{178}$.

Nessa seara, ainda que a indenização do INSS derive de um ato instantâneo, os danos perpetuam-se no tempo, uma vez que os benefícios são pagos mensalmente ao segurado ou a seus dependentes. Por isso, tendo-se por base que a pretensão de ressarcimento da autarquia previdenciária tem fulcro em uma relação de trato sucessivo, são inexigíveis apenas as parcelas atingidas pelo prazo prescricional ${ }^{179}$.

As parcelas estarão fulminadas pela prescrição se excederem os cinco anos anteriores ao ajuizamento da demanda, se for adotado o Decreto 20910/32 como fundamento sobre o tempo de exercício do direito de regresso.

Na hipótese de se utilizar as regras da lei civil para regular a prescrição, as parcelas estarão inexigíveis se ultrapassarem os três ou os vinte anos anteriores ao ingresso da demanda, se aplicado para os fatos ocorridos na égide do Código Civil de 2002 e de 1916, respectivamente. Entretanto, para os fatos ocorridos sob o manto do Código Civil de

\footnotetext{
${ }^{176}$ Esse é o posicionamento do Superior Tribunal de Justiça consubstanciado no REsp 698.195-DF, Rel. Min. Jorge Scartezzini, DJ 29/05/2006 e também manifestado no enunciado $\mathrm{n}^{\circ} 50$ da I Jornada de Direito Civil promovida pelo Centro de Estudos Judiciários da Justiça Federal, in verbis: "Art. 2.028: a partir da vigência do novo Código Civil, o prazo prescricional das ações de reparação de danos que não houver atingido a metade do tempo previsto no Código Civil de 1916 fluirá por inteiro, nos termos da nova lei (art. 206)". CONSELHO DA JUSTIÇA FEDERAL. I Jornada de Direito Civil. Enunciado $n^{o}$ 50. Disponível em: $<$ http://daleth.cjf.jus.br/revista/enunciados/IJornada.pdf>. Acesso em: 17 mar. 2012.

${ }^{177}$ MACIEL, Fernando. Ações regressivas acidentárias. São Paulo: LTr, 2010. p. 75.

${ }^{178}$ MELLO, Celso Antônio Bandeira de. Curso de direito administrativo. 17. ed. São Paulo: Malheiros Ed., 2004. p. 931.

${ }^{179}$ MACIEL, Fernando. op. cit., p. 77-78.
} 
1916 e atingidos pelo Código Civil de 2002, o prazo prescricional de três anos, com início no dia de entrada em vigor do novo diploma, atinge os últimos três anos de concessão dos benefícios acidentários.

Praticado o ato ilícito pelo empregador negligente e nascido para o INSS o direito de ação, resta verificar qual ramo do Poder Judiciário seria competente para julgar a lide. Novamente, é o objeto da demanda que determinará o foro competente. No presente caso, essa demanda indenizatória deverá ser processada na Justiça Federal, uma vez que o artigo 109, inciso I, da Constituição Federal estipula que compete aos juízes federais processar e julgar as causas em que entidade autárquica figure como autora, ré, assistente ou oponente, exceto as de falência, as de acidentes do trabalho e as sujeitas à Justiça Eleitoral e à Justiça do Trabalho.

Essa demanda não coincide com as acidentárias, pois enquanto nas lides regressivas a autarquia previdenciária é a autora que postula o ressarcimento dos gastos com o pagamento dos benefícios acidentários, sob o argumento da responsabilidade do empregador negligente que é o réu, nas demandas acidentárias, os segurados ou seus dependentes são postulantes de benefícios acidentários previstos em lei e o INSS é figurante do polo passivo. Portanto, os elementos da demanda (pedido, causa de pedir e partes) são diferentes.

Em decorrência, não há espaço para o instituto da denunciação da lide ao empregador negligente nas demandas acidentárias. De acordo com Cândido Rangel Dinamarco, denunciação da lide é uma demanda com que a parte provoca a integração de um terceiro ao processo pendente para o duplo efeito de auxiliá-lo no litígio com o adversário comum e de figurar como demandado em um segundo litígio ${ }^{180}$. As hipóteses de litisdenunciação estão enumeradas no artigo 70 do Código de Processo Civil e descrevem situações de direito material em que o terceiro é, em tese, obrigado a ressarcir a parte por aquilo que ela vier a perder ou deixar de ganhar no processo.

A previsão contida no inciso III do referido artigo é a que poderia suscitar dúvidas sobre o cabimento do instituto para as demandas regressivas do INSS, haja vista que traz a hipótese de denunciação da lide para aquele que estiver obrigado, pela lei ou pelo contrato, a indenizar, em ação regressiva, o prejuízo do que perder a demanda.

\footnotetext{
${ }^{180}$ DINAMARCO, Cândido Rangel. Instituições de direito processual civil. 4. ed. São Paulo: Malheiros Ed., 2004. v. 2, p. 398.
} 
Como se nota, o empregador somente é obrigado a indenizar os prejuízos sofridos pelo INSS se restar demonstrado que agiu de modo negligente quanto às normas de segurança e de medicina do trabalho. Dessa forma, essa obrigação do empregador não decorre imediatamente da lei ou de contrato, mas sim de prova de sua conduta negligente.

Por sua vez, a ação acidentária opera-se pelo simples nexo causal e a incapacidade, em virtude da responsabilidade objetiva fundada na teoria do risco social. Outrossim, a denunciação da lide tem natureza jurídica de direito de ação e, consequentemente, o juízo deve ser competente para a ação acidentária e para a regressiva. A demanda regressiva é processada na Justiça Federal e, embora o INSS figure como réu na lide acidentária, o artigo 109 da Constituição excepciona as lides decorrentes de acidentes do trabalho e, por isso, seu curso ocorre na Justiça Estadual.

Portanto, o INSS poderá ressarcir-se de eventuais prejuízos que sofrer com a concessão de benefícios acidentários diante da negligência do empregador em observar as normas de segurança e de medicina do trabalho. A solidariedade social em que se alicerça o sistema de segurança não pode servir de escudo para aqueles que não cumprem suas obrigações de meio ambiente do trabalho. Trata-se de uma demanda de natureza cível que segue as regras prescricionais do novo Código Civil e é processada na Justiça Federal.

Assim, não se confunde com a ação acidentária, que é fundada no risco social e promovida pelos segurados ou por seus dependentes na Justiça Estadual, com vista à concessão dos benefícios acidentários. A diferença de natureza entre essas demandas afasta a possibilidade de eventual denunciação da lide ao empregador para ressarcir as despesas efetuadas com o pagamento dos benefícios.

Feitas essas ponderações, sabe-se que os danos efetivos dos acidentes do trabalho que extrapolem a mera subsistência ficam sem proteção previdenciária, pois o benefício da autarquia previdenciária tem apenas o caráter alimentar de assegurar a sobrevivência da vítima e/ou seus dependentes.

Na França, o limite dessa indenização é limitado ao caráter alimentar, salvo em caso de culpa inescusável do empregador, que haverá, além da indenização automática dos órgãos de seguridade social, a indenização dos prejuízos complementares. O empregador é 
obrigado a concorrer com a seguridade social pela indenização integral somente no caso de culpa inescusável $^{181}$.

Contudo, no Brasil, sabe-se que paralelamente a essa cobertura acidentária pelo INSS existe a indenização dos danos provenientes do acidente do trabalho baseada na responsabilidade civil. Para completar a indenizabilidade do trabalhador acidentado, esse benefício previdenciário pode ser cumulado com a indenização de direito civil a cargo do empregador, que também está obrigado a concluir um contrato de seguro privado a favor de seu empregado, conforme demonstrar-se-á no capítulo quarto. O preceito insculpido no artigo 201, parágrafo 10, da Constituição corrobora que a cobertura do risco de acidente do trabalho será atendida, concorrentemente, pelo regime geral de previdência social e pelo setor privado.

Antes, porém, de verificar a garantia da indenização integral da vítima, cumpre analisar qual o fundamento dessa responsabilidade civil.

${ }^{181}$ SUPIOT, Alain. op. cit., p. 117. 


\section{RESPONSABILIDADE CIVIL DO ACIDENTE DO TRABALHO}

\subsection{Definição}

De acordo com Henri e Leon Mazeaud, nasce responsabilidade toda vez que o indivíduo tiver que indenizar um prejuízo. Dessa forma, eles afirmam que o autor do dano e a vítima são duas pessoas distintas e, entre elas, nasce um conflito de interesses ${ }^{182}$.

Sérgio Cavalieri Filho diz que, para a configuração da responsabilidade civil, são necessárias três condições: o dano, o ato ilícito e a causalidade, isto é, nexo de causa e efeito entre os primeiros elementos. Esse doutrinador aponta casos excepcionalíssimos, previstos em lei, de responsabilidade por ato lícito, como o dano causado por estado de necessidade. Nessas hipóteses, não haveria responsabilidade em sentido técnico, mas mero dever de indenizar por ato lícito. Em seu entender, mesmo nos casos de responsabilidade sem culpa, não se pode falar em ato lícito, uma vez que há sempre violação de um dever preexistente, o que configure a ilicitude ${ }^{183}$.

Destaca-se que a ilicitude tem como núcleo a circunstância de ser contrária ao direito $^{184}$. A iliceidade da conduta está na infração de um dever preexistente ${ }^{185}$. Assim, a ilicitude é a prática de um ato contrário a uma norma jurídica, independentemente de qualquer referência ao elemento psicológico.

Fernando Noronha também assevera que responsabilidade consiste em indenizar quaisquer danos antijuridicamente causados a outrem, ou seja, em violação com o ordenamento $^{186}$.

Em contrapartida, Maria Helena Diniz sustenta que a responsabilidade civil é a imputação de medidas que obriguem alguém a indenizar o dano moral ou o patrimonial causado a terceiros, em virtude de ato próprio imputado, de pessoa por quem ele responde,

\footnotetext{
${ }^{182}$ MAZEAUD, Jean; MAZEAUD, Leon. op. cit., t. 1, p. 2.

${ }^{183}$ CAVALIERI FILHO, Sérgio. Programa de responsabilidade civil. 6. ed. São Paulo: Malheiros Ed., 2005. p. 31.

${ }^{184}$ MELLO, Marcos Bernardes de. Teoria do fato jurídico: plano da existência. 12. ed. São Paulo: Saraiva, 2003. p. 132.

${ }^{185}$ PEREIRA, Caio Mário da Silva. Instituições de direito civil: teoria geral das obrigações. 19. ed. Rio de Janeiro: Forense, 2002. v. 1, p. 416.

${ }^{186}$ NORONHA, Fernando. Direito das obrigações. 3. ed. São Paulo: Saraiva, 2010. v. 1, p. 452.
} 
ou de fato de coisa ou animal sob sua guarda, ou, ainda, de simples previsão legal ${ }^{187}$. Então, no seu entender, para que haja responsabilidade civil, deve existir um dano, um prejuízo que a pessoa sofre, uma vítima.

Em sentido semelhante, Marcos Bernardes de Mello alega que existem atos humanos não contrários ao Direito (lícitos) que causam prejuízos ao patrimônio de terceiros, com o dever de indenizar. $\mathrm{O}$ autor inclui nessa categoria a indústria perigosa regularmente permitida ${ }^{188}$.

Então, entende-se que responsabilidade civil é a obrigação de indenizar outrem pelos prejuízos decorrentes de um comportamento contrário ao Direito, haja vista ser decorrente do descumprimento de uma norma jurídica já prevista em lei ou em contrato, independentemente do elemento volitivo do agente nessa conduta.

\subsection{Modalidades de responsabilidade civil no direito brasileiro}

A responsabilidade civil possui diferentes espécies que podem ser classificadas em: contratual ou extracontratual, conforme a origem ou o fato gerador e, ainda, em subjetiva ou objetiva, de acordo com o elemento subjetivo dessa conduta.

\subsubsection{Responsabilidade extracontratual ou aquiliana}

Tendo-se como pressuposto que a responsabilidade civil é decorrente de ato ilícito, a extracontratual é aquela deflagrada pela violação de um dever legal, sem relação jurídica preexistente entre os atores envolvidos.

Conforme Pontes de Miranda, a responsabilidade por acidentes do trabalho é extracontratual, pois a relação jurídica entre empregado e empregador é apenas suporte fático para a incidência das regras jurídicas sobre a indenização. A responsabilidade civil extracontratual consubstanciar-se-ia em uma relação jurídica entre empregadores e

\footnotetext{
${ }^{187}$ DINIZ, Maria Helena. Curso de direito civil brasileiro: responsabilidade civil. 24. ed. São Paulo: Saraiva, 2010. v. 7, p. 34.

${ }^{188}$ MELLO, Marcos Bernardes de. op. cit., p. 131-132.
} 
quaisquer empregados, resultante de infração de dever perante eles, e não perante cada um de per $\mathrm{si}^{189}$.

Sebastião Geraldo de Oliveira afirma que essa responsabilidade decorre de ato ilícito do empregador que viola os deveres previstos nas normas gerais de proteção ao trabalhador e ao meio ambiente do trabalho ${ }^{190}$.

Judith Martins-Costa apresenta algumas distinções entre responsabilidade contratual e a extracontratual ${ }^{191}$.

Inicialmente, a capacidade das partes é um elemento diferenciador, pois a responsabilidade contratual pressupõe capacidade negocial, enquanto a responsabilidade extracontratual atinge os incapazes. No que se refere à matéria de prova, na responsabilidade fundada no negócio jurídico preexistente, o devedor deverá provar que a prestação não era devida, ou que o inadimplemento não decorreu de culpa sua ou não lhe era imputável. Por outro lado, na responsabilidade aquiliana, o autor tem o ônus de provar os fatos constitutivos de seu direito (artigo 333, inciso I, do Código de Processo Civil), ou seja, o dano, a ilicitude, o nexo causal e a culpa e, apenas, o dano, a ilicitude e o nexo causal na responsabilidade objetiva.

No tocante ao termo inicial para a fixação da indenização, a responsabilidade contratual pode depender de prévia interpelação, notificação ou protesto, e a responsabilidade extracontratual tem como dies a quo a data da prática do ato. O pedido indenizatório deverá ser analisado no lugar em que o contrato deva ser cumprido na responsabilidade contratual e, no local onde ocorreu o ilícito, na responsabilidade extracontratual. Ainda, na responsabilidade contratual existe a possibilidade de pré-fixação do dano com a inserção de cláusula penal ${ }^{192}$.

Todavia, as obrigações de segurança integram o contrato de trabalho e, consequentemente, a responsabilidade tem seu fulcro nesse próprio negócio jurídico.

\footnotetext{
${ }^{189}$ PONTES DE MIRANDA, Francisco Cavalcanti. op. cit., t. 54 p. 86.

${ }^{190}$ OLIVEIRA, Sebastião Geraldo. op. cit., p. 88.

${ }^{191}$ MARTINS-COSTA, Judith. Comentários ao novo Código Civil: do inadimplemento das obrigações: arts. 389 a 420. Rio de Janeiro: Forense, 2004.p. 100-102. (Coleção Comentários ao Novo Código Civil Coord. Sálvio de Figueiredo Teixeira).

${ }^{192}$ Cláusula penal é uma cláusula acessória que se inflinge uma sanção econômica, em dinheiro ou outro bem estimado em pecúnia, para a parte que descumpre uma obrigação. PEREIRA, Caio Mário da Silva. op. cit., v. 2, p. 93.
} 


\subsubsection{Responsabilidade contratual}

Conforme o artigo 442 da Consolidação das Leis do Trabalho, contrato de trabalho é: "O acordo tácito ou expresso correspondente à relação de emprego".

Do ponto de vista doutrinário, o contrato de trabalho é um negócio jurídico pelo qual uma pessoa natural (empregado) se obriga, mediante o pagamento de uma contraprestação (salário), a prestar trabalho não eventual em proveito de outra pessoa, natural ou jurídica (empregador), a quem fica juridicamente subordinada ${ }^{193}$.

Dessa forma, o contrato de trabalho é fonte de obrigações recíprocas entre as partes. Essas obrigações têm como objetos principais ${ }^{194}$ : uma prestação de fazer por parte do empregado e uma prestação de dar do empregador. Por sua vez, o objeto da prestação do patrão é uma determinada quantia em dinheiro (salário), ao passo que do empregado é o próprio trabalho.

Além das prestações principais, o contrato de trabalho traz obrigações com prestações secundárias ou acidentais. Essas obrigações admitem uma subdivisão, qual seja: deveres de prestação secundários meramente acessórios ou anexos à obrigação principal, e os deveres de prestação secundários com prestação autônoma sucedânea ou coexistente com o dever principal ${ }^{195}$.

As normas de segurança e medicina do trabalho estão espalhadas em todo o ordenamento jurídico, desde a Constituição até os atos infralegais expedidos pelo Poder Executivo. Essas normas veiculam direitos revestidos de indisponibilidade absoluta ${ }^{196}$ e integram o contrato de trabalho e, assim, constituem prestações secundárias autônomas e coexistentes com a obrigação principal. Consequentemente, esses deveres de prestação secundários conferem ao empregado um direito à prestação de um meio ambiente do trabalho salubre, ao qual corresponde o dever legal de o empregador fornecer os equipamentos e instrumentos de proteção à saúde do trabalhador.

\footnotetext{
${ }^{193}$ MARANHÃO, Délio. Contrato de trabalho. In: SÜSSEKIND, Arnaldo; MARANHÃO, Délio; VIANNA, Segadas; TEIXEIRA, Lima. Instituições de direito do trabalho. 20. ed. São Paulo: LTr, 2002. v. 1, p. 236.

${ }^{194}$ AZEVEDO, Álvaro Villaça. Teoria geral das obrigações. 8. ed. São Paulo: Ed. Revista dos Tribunais, 2000. p. 35.

${ }^{195}$ MARTINS-COSTA, Judith. op. cit., p. 35.

${ }^{196}$ As normas que revestem direitos de indisponibilidade absoluta são aquelas que não podem ser negociadas nem mesmo pelos sindicatos. DELGADO, Maurício Godinho. Curso de direito do trabalho. 4. ed. São Paulo: LTr, 2005. p. 1321.
} 
Existem, ainda, os deveres instrumentais, entre os quais se inserem os de proteção. Esses deveres não estão voltados para o cumprimento do dever de prestar, mas visam à salvaguarda de outros interesses que devam ser considerados pelas partes no curso da relação obrigacional.

Os deveres instrumentais de proteção têm como escopo proteger a contraparte dos riscos de danos à sua pessoa e ao seu patrimônio, incluindo nesse rol: os deveres de lealdade, de cuidado, de previdência e segurança, de aviso e esclarecimento, de evitar ou diminuir os riscos, dentre outros ${ }^{197}$. À medida que os deveres primários e secundários são calcados na autonomia privada ${ }^{198}$ e na lei, os deveres instrumentais se fundam na boa-fé objetiva $^{199}$.

No contrato de trabalho, o empregador tem, ao lado dos deveres primários e secundários, os deveres instrumentais de proteção: de incolumidade física e psíquica do trabalhador e, sobretudo, o dever de segurança. $\mathrm{O}$ adimplemento obrigacional necessita ser adequado ao fim que se destina.

O desrespeito a essas normas enseja a inexecução contratual, que também é fonte de obrigações. Raimundo Simão de Melo aponta que a inobservância desse dever de segurança é a origem das condições inseguras de trabalho ${ }^{200}$.

Na hipótese de inexecução contratual, surge uma obrigação nova que substitui a obrigação preexistente, no todo ou em parte, qual seja: a obrigação de reparar o prejuízo decorrente da inexecução da obrigação assumida ${ }^{201}$.

O inadimplemento contratual é a não realização da prestação que era imputada ao credor ou ao devedor.

Essa imputação pode ser objetiva ou necessitar do elemento culpa. De acordo com Clovis Beviláqua, nos contratos bilaterais, cada uma das partes responde por culpa,

\footnotetext{
${ }^{197}$ MARTINS-COSTA, Judith. op. cit., p. 38.

${ }^{198}$ Autonomia privada é: "a esfera de determinação e regramento das relações pessoais, reconhecida aos particulares para a satisfação de suas necessidades e pretensões concretas, divisíveis e determinadas, com efeitos jurídicos circunscritos ao círculo de atributividade dos seus participantes”. SANTOS, Ronaldo Lima dos. Teoria das normas coletivas. 2. ed. São Paulo: LTr, 2009. p. 121.

${ }^{199}$ A boa-fé pode ser distinguida em subjetiva e objetiva. A objetiva é uma regra de conduta que se traduz por deveres de informação e de lealdade que devem existir em uma relação obrigacional, ao passo que a subjetiva é uma proteção conferida ao sujeito a partir de um estado de ignorância qualificada. Tanto a boa-fé objetiva quanto a subjetiva estão dentro do princípio da confiança que deve nortear o ordenamento jurídico. CORDEIRO, António Menezes. Da boa-fé no direito civil. Coimbra: Almedina, 2007. p. 410 e 648.

${ }^{200}$ MELO, Raimundo Simão de. op. cit., p. 244-245.

${ }^{201}$ DIAS, José de Aguiar. op. cit., v. 1, p. 149.
} 
entendida esta como a falta de diligência no cumprimento das obrigações convencionais ${ }^{202}$. Logo, para esse doutrinador, a imputação é sempre culposa.

Todavia, Pontes de Miranda diferencia imputabilidade de culpa, afirmando que é possível mora sem culpa ${ }^{203}$. Logo, não somente os casos de inadimplemento imputável de modo subjetivo, mas também aqueles de inadimplemento imputável fundado no risco, na atividade, na confiança ou na quebra do dever de garantia ensejam a responsabilidade pelas perdas e danos ${ }^{204}$.

Portanto, o contrato de trabalho acarreta para o empregador o dever de incolumidade física e psíquica do empregado. Em caso de não realização da prestação devida, tem-se a imputação da responsabilidade de perdas e danos ao devedor dessa obrigação, que é o empregador.

As normas, que veiculam direitos revestidos de indisponibilidade absoluta e a própria boa-fé, são impositivas de limites à autonomia privada e, por conseguinte, as partes não têm poder jurídico para afastar ou para limitar a responsabilidade por meio de cláusula penal, que estabeleça um patamar máximo de indenização, ou de regra que exonere o empregador do pagamento dos prejuízos provenientes da inexecução contratual.

Essa imputação não se confunde com inculpação. Por isso, é perfeitamente possível ter-se uma responsabilidade contratual fundada no risco da atividade ou no dever de segurança que é imposto por lei ou com base na boa-fé, independentemente de culpa.

Contudo, há uma simbiose entre esses dois tipos de responsabilidade, uma vez que as regras aplicadas para a responsabilidade contratual são também aplicadas à responsabilidade extracontratual no efeito de pagamento das perdas e danos ${ }^{205}$. Fernando Noronha diz que é possível uma responsabilidade negocial subjetiva e outra objetiva ${ }^{206}$.

O inadimplemento de obrigação contratual rege-se pelo artigo 389 do Código Civil, que estabelece que o devedor responde por perdas e danos, mais juros e atualização monetária, conforme os índices oficiais reconhecidos, além de honorários advocatícios.

\footnotetext{
${ }^{202}$ BEVILAQUA, Clovis. Código Civil dos Estados Unidos do Brasil. 4. ed. Rio de Janeiro: Francisco Alves, 1934. p. 218-219.

${ }^{203}$ PONTES DE MIRANDA, Francisco Cavalcanti. Tratado de direito privado. 3. ed. São Paulo: Ed. Revista dos Tribunais, 1983. t. 23, § 2.800, p. 126.

${ }^{204}$ MARTINS-COSTA, Judith. op. cit., p. 88.

${ }^{205}$ CAVALIERI FILHO, Sérgio. op. cit., p. 39.

${ }^{206}$ NORONHA, Fernando. op. cit., v. 1, p. 577.
} 
Infere-se, então, que a responsabilidade pelos acidentes do trabalho é contratual pelas normas ambientais do trabalho que integram o contrato, bem como pelos deveres instrumentais de proteção imputados ao empregador em face do empregado.

Entretanto, o ponto fulcral da responsabilidade civil reside em afirmar se a culpa pode ser imputada ou não ao sujeito obrigado ao cumprimento das normas de segurança e de medicina do trabalho que foram violadas.

\subsubsection{Responsabilidade subjetiva}

Por uma interpretação meramente literal, tem-se que a responsabilidade do empregador nos acidentes do trabalho é fundamentada no dolo ou na culpa, insculpida no inciso XXVIII, artigo $7^{\circ}$ da Constituição Federal de 1988, que prescreve como direito dos trabalhadores urbanos e rurais, além de outros que visem à melhoria de sua condição social: o seguro contra acidentes de trabalho, a cargo do empregador, sem excluir a indenização a que este está obrigado, quando incorrer em dolo ou em culpa.

Com amparo nesse dispositivo, Sergio Cavalieri Filho afirma que a responsabilidade por acidente do trabalho a cargo do empregador é subjetiva, ou seja, é afastada nos casos em que não ocorrer qualquer parcela de culpa do empregador ${ }^{207}$.

Então, o dever de indenizar somente surge quando estiverem presentes os seguintes pressupostos: o dano, evento trabalho, nexo de causalidade e a culpa ou o dolo do empregador, incumbindo à vítima o ônus de prova ${ }^{208}$, salvo nas situações de culpa presumida.

Henri e Leon Mazeaud dizem que dolo é o agir com a intenção malévola de causar um dano e a culpa é o erro de conduta que não seria cometido por uma pessoa nas mesmas circunstâncias que o autor do dano ${ }^{209}$. Dessa forma, os autores mesclam a noção de culpa in abstrato, que se utiliza do paradigma do homem diligente como limite de conduta normal, com as condições da realidade concreta que está submetido esse autor do dano.

\footnotetext{
${ }^{207}$ CAVALIERI FILHO, Sérgio. op. cit., p. 161.

${ }^{208}$ GONÇALVES, Carlos Roberto. Comentários ao Código Civil: parte especial: direito das obrigações. São Paulo: Saraiva, 2003. p. 257-258. (Coordenador da Coleção, v. 11, Antônio Junqueira de Azevedo).

${ }^{209}$ MAZEAUD, Jean; MAZEAUD, Leon. op. cit., t. 1, p. 405 e ss.
} 
Contrariamente, para Alvino Lima, culpa é "um erro de conduta, moralmente imputável ao agente e que não seria cometido por uma pessoa avisada, em iguais circunstâncias de fato ${ }^{210}$, . Dessa forma, o autor considera um modelo abstrato de conduta para ser seguido que, entretanto, não é observado pelo agente culpado.

De acordo com José de Aguiar Dias, o dolo é o elemento interno que reveste o ato com a intenção de causar o resultado. Por outro lado, a culpa é a vontade dirigida ao fato causador da lesão, todavia, o resultado não é desejado pelo autor do dano ${ }^{211}$.

Assim, a conduta das pessoas deve ser baseada na observância do dever geral de cautela ou no agir de modo a não lesar ninguém. A legislação brasileira não definiu culpa, mas o artigo 186 do Código Civil de 2002 refere-se ao ato ilícito, isto é, aquele ato praticado pelo homem por meio de uma conduta positiva ou negativa voluntária, negligência ou imprudência, que viola direitos e causa dano a outrem, ainda que exclusivamente moral.

O empregador, ao adotar uma conduta que revela imprudência, negligência ou imperícia, age culposamente. Imprudência é o agir sem os cuidados necessários e implica em pouca consideração pelos interesses alheios. A negligência é a falta de atenção e reflexão que faz com que o agente não preveja o resultado que deveria ou poderia prever. A imperícia é a ausência de aptidão técnica, isto é, a culpa profissional. Assim, o termo negligência inserido no texto legal abrange a noção de imperícia ${ }^{212}$.

Em decorrência lógica dos conceitos de culpa, sua análise deve ser in abstrato, ou seja, deve-se comparar a conduta do autor do ato àquela do homem abstratamente diligente, prudente e circunspecto, não se tendo em conta a sua educação, instrução e aptidões pessoais. O modelo de comparação é o homem normal, que vive entre nós, que age sempre em determinadas circunstâncias de um modo uniforme. Apesar da predominância da teoria da culpa in abstrato, existe a culpa in concreto, ou seja, aquela em que se deve considerar a consciência do autor do dano, sondar seu íntimo ${ }^{213}$.

Este padrão abstrato do homem diligente é também referência para os graus de culpa em: grave, leve e levíssima. A culpa grave é aquela falta de atenção ou de cuidado grosseiro que se exige de qualquer pessoa sensata. De outro modo, a culpa leve é o erro de

\footnotetext{
${ }^{210}$ LIMA, Alvino. op. cit., p. 69.

${ }^{211}$ DIAS, José de Aguiar. op. cit., v. 1, p. 140.

${ }^{212}$ GONÇALVES, Carlos Roberto. op. cit., p. 19.

${ }^{213}$ LIMA, Alvino. op. cit., p. 57-58.
} 
conduta que não é esperado do homem reto, probo, cuidadoso, prudente. Finalmente, a culpa levíssima é o mínimo desvio de comportamento ${ }^{214}$.

Conforme já verificado no capítulo 2, a legislação francesa somente permite a indenização complementar de acidente de trabalho, a cargo do empregador, se esse proceder com culpa inescusável, isto é, a culpa grave.

A Segunda Câmara Civil da Corte de Cassação francesa, no aresto nº 09-68764, definiu que o contrato de trabalho impõe ao empregador uma obrigação de segurança em relação aos seus empregados. No caso em tela, o empregado caiu de uma escada quase vertical que dava acesso ao mezanino da cozinha que, por sua vez, estava sem o guardacorpo de proteção. Dessa forma, o empregador foi condenado em indenizar seu empregado, pois não poderia ignorar os riscos que seus empregados estavam expostos, se ele não realizou de medidas de preservação meio ambiente do trabalho para evitar o acidente, mesmo após avisado por outros empregados ${ }^{215}$.

Apesar da insuficiência da responsabilidade subjetiva para indenização dos danos aos empregados acidentados, existem decisões do Tribunal Superior do Trabalho (TST) que exigem que o empregado prove a culpa do empregador ${ }^{216}$.

\footnotetext{
${ }^{214}$ GOMES, Orlando. Obrigações. 13. ed. Rio de Janeiro: Forense, 2000. p. 267.

${ }^{215}$ CORTE DE CASSAÇÃO NA FRANÇA. SEGUNDA CÂMARA CIVIL. Aresto no 09-68.764, de 23 de setembro de 2010. Disponível em: <http://www.editions-tissot.fr/droit-travail/jurisprudence-sante-securitefiche-print.aspx?occId=141>. Acesso em: 15 nov. 2012.

${ }^{216}$ RECURSO DE REVISTA. INDENIZAÇÃO POR DANO MORAL. ACIDENTE DE TRABALHO. RESPONSABILIDADE DO EMPREGADOR. A Constituição da República incluiu entre os direitos do empregado o seguro contra acidentes de trabalho, a cargo do empregador, sem excluir a indenização a que este está obrigado, quando incorrer em dolo ou culpa (art. $7^{\circ}$, inc. XXVIII). Assim, constata-se que a Constituição da República, quanto à indenização por danos material e moral, provenientes de infortúnios do trabalho, adotou a teoria da responsabilidade subjetiva do empregador. $\mathrm{Na}$ hipótese dos autos, a responsabilidade objetiva da reclamada pela indenização por danos decorrentes do acidente de trabalho foi declarada pelo Tribunal Regional, ao atestar que "nossa linha de reflexão segue a doutrina mais autorizada da objetivação da culpa, em tais hipóteses" (fl. 102). Dessa forma, consoante quadro expresso pelo Tribunal Regional, não tendo sido demonstrada a ocorrência de culpa da reclamada para o surgimento do dever de indenizar, deve ser afastada a condenação ao pagamento de indenização por danos morais. Recurso de revista que se conhece e a que se dá provimento (5a Turma, RR 1376/2005-002-19-40.8, j. 24/09/2008, Rel. Ministro João Batista Brito Pereira, DEJT 10/10/2008). TRIBUNAL SUPERIOR DO TRABALHO. Disponível em: <aplicacao5.tst.jus.br/consultaunificada2/\#topoPag>. Acesso em: 09 nov. 2012.

RECURSO DE REVISTA. DANOS MORAIS. DOENÇA DO TRABALHO. Pela análise dos fundamentos adotados na decisão recorrida, está claro que o Regional levou em consideração o contexto fáticoprobatório para consignar que restaram configurados os elementos da responsabilidade civil, quais sejam: culpa, nexo e dano. Qualquer entendimento contrário induz à ideia de inadmissibilidade da revista, na esteira da súmula 126 do TST, por remeter ao contexto probatório. Não conhecido. ( $5^{\mathrm{a}}$ Turma, RR -64800 -39.2003.5.09.0654, j. 05/05/2010, Rel. Ministro Emmanoel Pereira, DEJT 14/05/2010). TRIBUNAL SUPERIOR DO TRABALHO. Disponível <http://aplicacao5.tst.jus.br/consultaunificada2/jurisSearch.do>. Acesso em: 09 nov. 2012.
} 
Cumpre registrar que é possível também a culpa exclusiva da vítima no acidente do trabalho que configura o rompimento do nexo causal e não ocasiona o dever de indenizar. Raimundo Simão de Melo pondera que a culpa exclusiva da vítima pode consubstanciar em ato inseguro, que é a conduta indevida do homem capaz de gerar acidentes do trabalho ${ }^{217}$.

Diferente é a culpa concorrente ou recíproca da vítima. Nesse caso, a conduta da vítima também contribuiu para o acidente e não exclui a responsabilidade civil do empregador, mas autoriza o juiz a reduzir proporcionalmente o valor da indenização. Essa matéria é positivada no artigo 945 do Código Civil, ao determinar que, se a vítima tiver contribuído culposamente para o evento danoso, a sua indenização será fixada considerando-se a gravidade de sua culpa em confronto com a do autor do dano.

A culpa também pode decorrer da violação de uma norma legal. É a chamada "culpa contra a legalidade" 218 . A mera infração da norma que acarreta dano já é fator desencadeante da responsabilidade civil, pois cria a presunção de culpa, incumbindo ao réu o ônus da prova em sentido contrário. Continua-se na seara da responsabilidade subjetiva, de modo que o causador do dano tem o ônus de provar que não agiu com culpa. Trata-se de uma regra meramente processual de inversão do ônus da prova.

As normas legais e regulamentares impõem ao empregador deveres de proteção à incolumidade física e psíquica dos trabalhadores e têm por escopo evitar os acidentes do trabalho. Por outro lado, também constitui direito fundamental dos trabalhadores urbanos e rurais, dentre outros, a redução dos riscos inerentes ao trabalho, por meio de normas de saúde, de higiene e de segurança (artigo $7^{\circ}$, inciso XXII, da Constituição Federal).

A Consolidação das Leis do Trabalho (CLT) pontua como incumbência das empresas: a) observar e fazer cumprir as normas de segurança e medicina do trabalho; b) orientar os empregados, por meio de ordens de serviço, quanto às precauções a seguir no sentido de evitar acidentes do trabalho ou doenças ocupacionais; c) providenciar as medidas que lhes sejam determinadas pelo órgão regional competente; d) facilitar o exercício da fiscalização pela autoridade competente (artigo 157).

Em conformidade com a teoria da culpa contra a legalidade, se ocorrer um dano e, simultaneamente, as normas de segurança e de medicina do trabalho não tiverem sido

\footnotetext{
${ }^{217}$ MELO, Raimundo Simão de. op. cit., p. 252.

${ }^{218}$ CAVALIERI FILHO, Sérgio. op. cit., p. 65.
} 
seguidas, resta caracterizado que o empregador agiu com culpa contra a legalidade e, por conseguinte, ele terá o ônus de elidir essa presunção ${ }^{219}$. A utilização dessa teoria aproximase da responsabilidade sem culpa e, por isso, já demonstra a insuficiência da culpa para solucionar a indenização da vítima.

Assim, a extração da responsabilidade subjetiva da norma constitucional, nos casos de acidentes do trabalho, colide com a própria evolução do instituto jurídico da responsabilidade que caminhou em direção à objetividade.

\subsubsection{Responsabilidade objetiva}

Na responsabilidade objetiva não é necessário se perquirir sobre o elemento culpa.

Consoante já demonstrado, Sérgio Cavalieri Filho pugna que a responsabilidade sem culpa é caracterizada pelo dano, pela conduta ilícita e pelo nexo causal ${ }^{220}$. Apenas em casos excepcionais, admite-se a responsabilidade por ato lícito como no estado de necessidade.

Fernando Noronha diz que responsabilidade objetiva é a obrigação de indenizar danos, afastada qualquer ideia de dolo ou culpa. Para esse doutrinador, a antijuridicidade é um dado objetivo, ou seja, existe sempre que o fato ofender direitos alheios de modo contrário ao direito, independentemente de qualquer juízo de censura que possa estar presente e imputado a alguém ${ }^{221}$.

\footnotetext{
${ }^{219}$ O Tribunal Superior do Trabalho (TST) já proferiu julgado no sentido de reconhecer a culpa presumida. AGRAVO DE INSTRUMENTO EM RECURSO DE REVISTA. REQUISITOS INTRÍNSECOS DE ADMISSIBILIDADE. CARACTERIZAÇÃO. INOCORRÊNCIA. 1. ACIDENTE DO TRABALHO. ATIVIDADE DE RISCO. TRÂNSITO. CULPA PRESUMIDA. Por assumir os riscos da atividade econômica que explora, o empregador deve preservar a segurança dos seus empregados, observando as cautelas necessárias para impedir a ocorrência de infortúnios. Assim, se o empregado trabalha viajando de caminhão durante a totalidade da sua jornada, submetendo-se a um risco acentuado de acidente de trânsito, deve o empregador providenciar a adequada manutenção do veículo. Por isso, sobrevindo o acidente durante o horário de trabalho, a culpa patronal é presumida, devendo-se inverter o ônus da prova a favor da vítima, incumbindo ao empregador demonstrar a ocorrência de caso fortuito, força maior, culpa exclusiva da vítima, ou qualquer outra causa excludente do nexo causal ou da sua culpa. 2. Agravo não provido. (AIRR - 100840 - 11.2005.5.03.0074 , Relator Ministro: Guilherme Augusto Caputo Bastos, j: 17/12/2008, $7^{\mathrm{a}}$ Turma, Data de Publicação: 19/12/2008). TRIBUNAL SUPERIOR DO TRABALHO. Disponível em: $<$ http://aplicacao5.tst.jus.br/consultaunificada2/jurisSearchInSession.do?action=search\&basename=acordao \&index $=60>$. Acesso em: 10 nov. 2012.

${ }^{220}$ CAVALIERI FILHO, Sérgio. op. cit., p. 153.

${ }^{221}$ NORONHA, Fernando. op. cit., v. 1, p. 508-509.
} 
De outra parte, Alvino Lima informa que a responsabilidade objetiva deve surgir exclusivamente do fato, cujo foco é a vítima, pois lhe é assegurada a reparação do dano ${ }^{222}$.

Dentro desse contexto, Álvaro Villaça Azevedo divide a responsabilidade objetiva em duas categorias, quais sejam: pura e impura. Enquanto a impura tem como substrato a culpa de terceiro, que está vinculado à atividade do indenizador, a pura enseja o ressarcimento ainda que não exista culpa de qualquer dos envolvidos no evento danoso. Assim, esse autor conclui que a responsabilidade objetiva pura enseja indenização por ato lícito ou mero fato jurídico. Consequentemente, na responsabilidade objetiva pura, o indenizador é responsável pelo dano na integralidade e não existe qualquer possibilidade de ação de regresso ${ }^{223}$.

Infere-se, então, que Álvaro Villaça Azevedo relaciona a ilicitude com culpa, haja vista que, no seu entender, o ato lícito ou fato jurídico apto a gerar responsabilidade objetiva pura é aquele sem qualquer culpa dos envolvidos.

Ressalva-se, contudo, a distinção adotada nessa dissertação entre ilicitude e inculpação, pois a responsabilidade é a obrigação de indenizar outrem pelos prejuízos em razão de um comportamento contrário ao Direito, haja vista ser decorrente do descumprimento de uma norma jurídica já prevista em lei ou em contrato, independentemente do elemento volitivo do agente nessa conduta.

Conforme já analisado no segundo capítulo, nos acidentes do trabalho, o risco social é o fundamento da responsabilidade previdenciária. Por outro lado, a indenização complementar no direito civil percorre outras justificativas no direito pátrio. Veja-se.

\subsubsection{Responsabilidade objetiva alicerçada no meio ambiente}

O artigo $3^{\circ}$, inciso I, da Lei de 6938/81 define meio ambiente nos seguintes termos: conjunto de condições, leis, influências e interações de ordem física, química e biológica que permite, abriga e rege a vida em todas as suas formas.

$\mathrm{O}$ artigo 14, $\S 1^{\circ}$, desse mesmo texto legal, trouxe insculpido o princípio do poluidor pagador, consubstanciado na regra da responsabilidade mesmo sem culpa daquele

\footnotetext{
${ }^{222}$ LIMA, Alvino. op. cit., p. 116.

${ }^{223}$ AZEVEDO, Álvaro Villaça. op. cit., p. 280.
} 
que causou danos ao meio ambiente e a terceiros, afetados por sua atividade ${ }^{224}$. Esse dispositivo foi recepcionado pela Constituição Federal de 1988, que determinou que os infratores sujeitar-se-ão às sanções penais e às administrativas, além de serem obrigados a reparar os danos causados (artigo $225, \S 3^{\circ}$ ).

Por outro lado, Marcelo Abelha Rodrigues diz que o fundamento da responsabilidade objetiva ambiental é o próprio artigo 225 , $\S 3^{\circ}$ da Constituição, haja vista que o constituinte não fez qualquer exigência da culpa para determinar a responsabilidade civil $^{225}$.

Assim, a responsabilidade por danos ambientais é objetiva, na espécie de risco integral, isto é, a relação de causalidade é pura e não se permite as excludentes do nexo causal $^{226}$. A relação de causalidade entre o fato e o dano é direta e, consequentemente, nasce o dever de indenizar, independentemente da vontade ou da consciência do agente ${ }^{227}$.

O meio ambiente do trabalho, por sua vez, é o local onde as pessoas desempenham atividades laborais, sejam remuneradas ou não, cujo equilíbrio está baseado na salubridade do meio e na ausência de agentes que comprometam a incolumidade físicopsíquica dos trabalhadores, independentemente da condição que ostentem ${ }^{228}$.

Dessa forma, Raimundo Simão de Melo apresenta como núcleo central de sua tese a possível contradição, antinomia ou conflito de normas entre o artigo $225, \S 3^{\circ}$, da Constituição, que estabelece a responsabilidade objetiva por danos ao meio ambiente e o artigo $7^{\circ}$, inciso XXVIII, que prevê a responsabilidade subjetiva em caso de acidente do trabalho. $\mathrm{O}$ autor parte do pressuposto de que não seria razoável tratar diferentemente os acidentes do trabalho que são a consequência maior dos danos ambientais que atingem a pessoa humana ${ }^{229}$.

De acordo com Raimundo Simão de Melo, o inciso XXVIII do artigo $7^{\circ}$ da Constituição não pode ser interpretado em desconsideração do caput do mesmo dispositivo, que prevê que os direitos dos trabalhadores urbanos e rurais visam à melhoria de sua condição social.

\footnotetext{
${ }^{224}$ MACHADO, Paulo Affonso Leme. op. cit., p. 335.

${ }^{225}$ RODRIGUES, Marcelo Abelha. op. cit., v. 1, p. 204.

${ }^{226} \mathrm{O}$ nexo causal e as respectivas causas excludentes serão analisados no item 3.3.

${ }^{227}$ GODOY, Claudio Luiz Bueno de. Responsabilidade civil pelo risco da atividade. 2. ed. São Paulo: Saraiva, 2010. p. 81.

${ }^{228}$ FIORILLO, Celso Antonio Pacheco. op. cit., p. 43-44.

${ }^{229}$ MELO, Raimundo Simão de. op. cit., p. 228-229.
} 
Os objetivos do Poder Público são: a) melhorar a condição social do trabalhador e; b) estabelecer um patamar mínimo de direitos considerados "fundamentais" aos empregados, sempre conferindo a possibilidade de ampliar o rol de direitos.

Trata-se, então, de uma cláusula aberta ${ }^{230}$ que permite que a responsabilidade do empregador por acidente do trabalho não fique restrita aos limites da culpa insculpida no inciso XXVIII do artigo $7^{\circ} \mathrm{e}$, sim, que seja ampliada e harmonizada com o determinado no $\S 3^{\circ}$ do artigo 225 , que assegura a responsabilidade objetiva pelos danos causados ao meio ambiente. A própria Constituição confere aos trabalhadores outros direitos e garantias decorrentes do regime e dos princípios por ela adotados ou dos tratados internacionais em que a República Federativa do Brasil seja parte (artigo $5^{\circ}$, $\S 2^{\circ}$, da Lei Maior).

Outrossim, a Constituição aduz que outros direitos mais favoráveis ao trabalhador podem ser introduzidos por normas de grau inferior, sejam elas heterônomas (lei em sentido estrito), sejam elas autônomas (resultantes do processo de negociação coletiva).

Raimundo Simão de Melo também se utiliza da teoria das normas inconstitucionais preconizadas por Otto Bachof para extirpar eventual contradição entre o artigo $7^{\circ}$, inciso XXVIII, e o artigo $225, \S 3^{\circ}$, ambos da Constituição.

De acordo com Otto Bachof, existe a possibilidade de normas constitucionais inconstitucionais, mesmo fruto de poder constituinte originário. Dessa forma, estaria configurada a possibilidade de uma norma constitucional ser inconstitucional e, consequentemente, não vinculativa, se ela infringisse outra norma constitucional de maior valor. $\mathrm{O}$ autor pontua que o legislador originário é livre para estabelecer a regra e sua respectiva exceção, mas não pode violar a norma de direito supralegal que proíbe o arbítrio da ordem jurídica ${ }^{231}$.

Com escólio nessa doutrina, Raimundo Simão de Melo entende o disposto no $§ 3^{\circ}$ do artigo 225 da Constituição como princípio maior (regra supralegal), que protege o direito fundamental de preservação da vida em todas as suas espécies e, em oposição, considera o inciso XXVIII do artigo $7^{\circ}$ da Constituição como uma norma de alcance menor ou até mesmo inválida diante da arbitrariedade do constituinte originário.

\footnotetext{
${ }^{230}$ Para Raimundo Simão de Melo, a cláusula aberta prevista no caput do artigo $7^{\circ}$ da Constituição permite buscar as respostas para as seguintes indagações: "por que", "para que" e "para quem" foi elaborada a referida norma. MELO, Raimundo Simão de. op. cit., p. 228.

${ }^{231}$ BACHOF, Otto. Normas constitucionais inconstitucionais? Trad. José Manuel M. Cardoso da Costa. Coimbra: Almedina, 1994. p. 54-59.
} 
Finalmente, esse autor complementa que o constituinte brasileiro não impôs uma exceção à regra geral de responsabilidade objetiva para os danos ambientais em caso de acidentes do trabalho, mas não teria controlado a compatibilidade entre os dois dispositivos em comento ${ }^{232}$.

Em que pese aos acidentes do trabalho sejam sinistros ocasionados por violação de normas de meio ambiente do trabalho e que o empregador tem o dever de respeitá-las, não se pode concordar com a responsabilidade objetiva calcada no artigo $225, \S 3^{\circ}$, da Constituição Federal, pelos argumentos expostos a seguir.

A fixação dessa responsabilidade sem culpa foi inserida em um dos parágrafos do artigo 225, que constitui o capítulo VI, autônomo, dentro do Título VIII, que trata da Ordem Social. Os parágrafos devem ser interpretados em conjunto com o caput do artigo para extrair-se o real alcance e sentido. Esse parágrafo refere-se à imputação da responsabilidade objetiva àqueles que praticam condutas lesivas ao meio ambiente natural, que é espécie distinta do meio ambiente do trabalho. Todo o capítulo está voltado para a preservação das riquezas naturais e não das artificiais.

O próprio patrimônio histórico-cultural que faz parte do meio ambiente artificial está inserido no capítulo III, seção II, e tem uma outra regra sobre a responsabilidade insculpida no $\S 4^{\circ}$ do artigo 215 da Constituição, qual seja, relega à lei a forma de punição dos danos e das ameaças ao patrimônio cultural. Caso a responsabilidade fosse sempre objetiva para qualquer espécie de meio ambiente, esse dispositivo constitucional que deixa a lei fixar os parâmetros para responsabilidade pelo meio ambiente cultural seria inócuo.

Outrossim, as discussões na Assembleia Nacional Constituinte permitem captar a mens legislatoris e conferir a interpretação autêntica do dispositivo. Em consulta às reuniões da Comissão de Redação, extrai-se dos diálogos, que os constituintes almejavam a defesa de ecologia ${ }^{233}$.

\footnotetext{
${ }^{232}$ MELO, Raimundo Simão de. op. cit., p. 229-230.

233،“Art. 224, caput. Para compatibilizar o texto do caput com os incisos do $\S 1^{\circ}$, substitua-se a expressão "impondo-se ao Poder Público o dever de defendê-lo e à coletividade o de preservá-lo" por "impondo-se ao Poder Público e à coletividade o dever de defendê-lo e preservá-lo".

O SR. CONSTITUINTE JOSÉ FOGAÇA: - Sr. Presidente, no art. 224 temos a defesa da ecologia, mas esta divisão de tarefas ou competências ou atribuições não pareceu clara nem própria à Relatoria. Ou seja, o Poder Público defende o meio ambiente e a coletividade o preserva. Isto parece que não é uma divisão lógica e clara. A ambos, Poder Público e coletividade, impõe-se o dever de defender e preservar. Daí a adaptação proposta.

O SR. PRESIDENTE (Ulysses Guimarães): - De acordo?

(Pausa.) Aprovada. SENADO FEDERAL. Assembleia Nacional Constituinte. Disponível em: <http://www.senado.gov.br/publicacoes/anais/asp/CT_Abertura.asp>. Acesso em: 19 jun. 2011.
} 
Dessa forma, a intenção do legislador foi conferir uma proteção ao meio ambiente natural, daí sua referência à ecologia. A definição de meio ambiente natural é ampla, abrangendo os ecossistemas e a biosfera.

Ademais, o Supremo Tribunal Federal (STF) já decidiu que a teoria de normas constitucionais originárias inconstitucionais de Otto Bachof não é aplicada no direito brasileiro, sob o fundamento de que o referido órgão não teria jurisdição para fiscalizar o Poder Constituinte originário, quer em face do direito suprapositivo não positivado na Constituição, quer diante do direito suprapositivo positivado, quer com base em normas constitucionais que seriam de grau superior ao das demais, pois, se o Poder Constituinte originário é livre para fixar um princípio, o é também para impor-lhe exceções ${ }^{234}$.

Portanto, estender a responsabilidade objetiva do meio ambiente natural a todo e qualquer meio ambiente não está em consonância e harmonia com a Constituição.

A responsabilidade objetiva pelo risco que a atividade normalmente causa aos direitos de outrem, conforme previsão no Código Civil de 2002, também despontou como fundamento da responsabilidade civil dos acidentes do trabalho.

\subsubsection{Responsabilidade objetiva pelo risco da atividade}

O artigo 927, parágrafo único, do Código Civil previu a responsabilidade objetiva nos casos de risco da atividade privada em geral, ao estabelecer que haverá obrigação de indenizar o dano, independentemente de culpa, nos casos especificados em lei, ou quando a atividade normalmente desenvolvida pelo autor do dano implicar, por sua natureza, risco para os direitos de outrem.

Além dos casos específicos previstos na legislação, esse dispositivo introduziu uma cláusula geral ${ }^{235}$ de responsabilidade sem culpa para as atividades particulares que impliquem risco para os direitos de outrem.

\footnotetext{
${ }^{234}$ SUPREMO TRIBUNAL FEDERAL. Ação Direta de Inconstitucionalidade $n^{o}$ 997-4. Plenário, Rel. Ministro Moreira Alves. Julgado em 28/03/1996. Disponível em: <http://www.stf.jus.br/portal/jurisprudencia/listarJurisprudencia.asp?s1=\%28997.NUME.+OU+997.ACMS \%29\&base=baseAcordaos $>$. Acesso em: 9 nov. 2012.

${ }^{235}$ De acordo com Judith Martins-Costa, "cláusula geral constitui uma disposição normativa que utiliza, em seu enunciado, uma linguagem de tessitura intencionalmente aberta, fluida ou vaga, caracterizando-se pela ampla extensão de seu campo semântico". MARTINS-COSTA, Judith. A boa-fé no direito privado. São Paulo: Ed. Revista dos Tribunais, 2000. p. 303.
} 
O dispositivo introduzido pelo Código Civil pátrio de 2002 foi inspirado no artigo 2050 do Código Civil italiano, que estabeleceu que todo aquele que causa dano aos outros pelo desenvolvimento de uma atividade perigosa, por sua natureza ou pelos meios usados, é obrigado ao ressarcimento, salvo se provar que adotou todas as medidas idôneas para evitar o dano ${ }^{236}$.

Apesar da ressalva do dispositivo, Pietro Trimarchi defendeu que a responsabilidade prevista nesse artigo seria objetiva, com a finalidade de exercer uma pressão econômica impessoal ao empreendimento perigoso, pelo risco a ele inerente, com o fim de evitar os danos.

A exceção prevista na parte final da regra traçou os limites da responsabilidade, quais sejam: os riscos objetivamente evitáveis. Esse autor afirmou que o legislador delimitou o risco, pois temia que a responsabilidade objetiva fosse muito gravosa e coincidisse com uma causalidade pura, mas, ao mesmo tempo, ele não queria que essas atividades tivessem o tratamento ameno da responsabilidade subjetiva ${ }^{237}$.

Contudo, a lei brasileira não concedeu oportunidade para o causador do dano provar que tomou todas as medidas aptas a impedir o dano e, assim, isentar-se da responsabilidade.

A atividade normalmente exercida pelo autor do dano não é uma ação ou omissão e, sim, uma conduta reiterada, habitualmente exercida, organizada de forma profissional ou empresarial para realizar fins econômicos ${ }^{238}$.

Para Fábio Konder Comparato, atividade é: "uma série de atos tendentes ao mesmo escopo. Ela engloba tanto atos ou negócios jurídicos, quanto simples atos materiais ${ }^{239,}$.

Nessa seara, Giselda Hironaka aponta que a Corte de Cassação italiana usou a noção de atividade em sentido dinâmico, ou seja, "pressupõe uma sucessão contínua e

\footnotetext{
${ }^{236}$ No original: "Chiunque cagiona danno ad altri nello svolgimento di unáttività pericolosa, per sua natura 0 per la natura dei mezzi adoperati, è tenuto al riarcimento, se non prova di avere adottato tutte le misure idonee ad evitarei 1 danno". IL CODICE Civile Italiano. Disponível em: $<$ http://www.jus.unitn.it/cardozo/obiter_dictum/codciv/Lib4.htm>. Acesso em: 10 nov. 2012.

${ }^{237}$ TRIMARCHI, Pietro. Rischio e responsabilità oggetiva. Milano: Giuffrè, 1961. p. $279-280$.

${ }^{238}$ CAVALIERI FILHO, Sérgio. op. cit., p. 182.

${ }^{239}$ COMPARATO, Fábio Konder; SALOMÃO FILHO, Calixto. O poder de controle na sociedade anônima. 4. ed. Rio de Janeiro, 2005. p. 125.
} 
repetida de atos que se desencadeiam no tempo e implicam um mínimo de continuidade da atividade e um mínimo de predisposição dos meios empregados no seu desempenho ${ }^{240,}$.

Claudio Luiz Bueno de Godoy pondera que atividade é: "um conjunto de atos seriados, habitualmente praticados, organizados e voltados a um fim, importando em relações interdependentes que podem ser afetadas e desequilibradas pelo evento lesivo ${ }^{241 \text { ". }}$

Assim, entende-se que atividade é um conjunto ordenado de atos direcionados a um objetivo e, consequentemente, forma um todo unitário.

Essa atividade do causador do dano implica, por sua natureza, riscos para os direitos de outrem. Ari Possidonio Beltran alega que esse dispositivo do Código Civil inseriu a teoria do risco criado, pois o dever de indenizar os danos surge da atividade normalmente exercida pelo agente que cria risco a direitos alheios ${ }^{242}$.

Sérgio Cavalieri Filho defende que a responsabilidade preconizada pelo novo Código Civil é baseada na falta de segurança razoavelmente esperada da atividade desenvolvida.

Dessa forma, se a atividade de risco for desenvolvida com segurança, acompanhada de informações adequadas, ou seja, a atividade executada com o cumprimento dos deveres instrumentais não acarreta a responsabilidade pelos eventuais danos causados. Só haverá a responsabilidade nos casos em que o risco foi adquirido, ou seja, a atividade se torna perigosa por apresentar algum defeito, pois existem riscos que são inerentes a certas atividades, umbilicalmente ligados à sua própria natureza e modo de funcionamento. Se todo e qualquer risco for transferido ao responsável pelo serviço acabaria de inviabilizar a própria atividade e a vida da sociedade contemporânea ${ }^{243}$.

As atividades geram uma expectativa legítima de segurança às pessoas se estiverem de acordo com o estágio técnico e as condições econômicas da época. Caso seja ultrapassada a expectativa legítima, haverá um perigo adquirido e uma possibilidade de indenização.

Finaliza Sérgio Cavalieri, se a atividade normalmente exercida pelo autor do dano implicar risco e ocorrer o dano, existirá o dever de indenizar por violação ao dever jurídico

\footnotetext{
${ }^{240}$ HIRONAKA, Giselda Maria Fernandes Novaes. op. cit., p. 300.

${ }^{241}$ GODOY, Claudio Luiz Bueno de. op. cit., p. 75.

${ }^{242}$ BELTRAN, Ari Possidonio. Da responsabilidade subjetiva e objetiva do empregador por acidente do trabalho, ante as disposições do novo Código Civil. Revista do Departamento de Direito do Trabalho e da Seguridade Social, Faculdade de Direito da USP, São Paulo, v. 1, n. 1, p. 16, jan./jun. 2006.

${ }^{243}$ CAVALIERI FILHO, Sérgio. op. cit., p. 184-185.
} 
de segurança. Essa segurança pauta-se pela expectativa legítima dos danos possivelmente causados e a intensidade dos riscos do empreendimento ${ }^{244}$.

Em outro sentido, Claudio Luiz Bueno de Godoy defende que se atividade criar um risco diferenciado, particular, ensejará a responsabilidade. Assim, não é o simples exercício de uma atividade perigosa que ensejará o dever de reparar o dano ${ }^{245}$.

Nessa seara, Giselda Hironaka pondera que a periculosidade da atividade desenvolvida deve ser especial, indutiva de um risco especial ${ }^{246}$.

A necessidade de verificar quais os riscos que são aptos a causar o dano e gerar a indenização provocou o surgimento do Enunciado $\mathrm{n}^{0} 38$, aprovado na I Jornada de Direito Civil do Conselho da Justiça Federal, ao afirmar que é atividade normalmente desenvolvida pelo autor do dano se ela causar a pessoa determinada um ônus maior do que aos demais membros da coletividade ${ }^{247}$.

Giovanni Ettore Nanni arrola algumas atividades que normalmente são desenvolvidas e podem implicar riscos maiores para os direitos de outrem, a saber: o transporte marítimo de petróleo, o transporte e a estocagem de combustível, a produção de explosivos, a produção e comercialização de fogos de artifício $^{248}$.

Essa exigência de exposição de um risco excepcional para dar margem à indenização também foi objeto de análise do Superior Tribunal de Justiça, inclusive em caso de acidente do trabalho ${ }^{249}$.

A aplicação da teoria da responsabilidade objetiva pelo risco da atividade em casos de acidentes do trabalho está fundamentada no próprio princípio constitucional da igualdade, haja vista que, se perante terceiros, o empregador responde, independentemente,

\footnotetext{
${ }^{244}$ CAVALIERI FILHO, Sérgio. op. cit., p. 186.

${ }^{245}$ GODOY, Claudio Luiz Bueno de. op. cit., p. 112.

${ }^{246}$ HIRONAKA, Giselda Maria Fernandes Novaes. op. cit., p. 297-300.

${ }^{247}$ CONSELHO DA JUSTIÇA FEDERAL. I Jornada de Direito Civil. Enunciado $n^{o} 38$. Disponível em: $<$ http://daleth.cjf.jus.br/revista/enunciados/IJornada.pdf>. Acesso em: 19 nov. 2012.

${ }^{248}$ NANNI, Giovanni Ettore. Responsabilidade no acidente do trabalho. Gazeta Mercantil, 13 out. 2003. Caderno Legal \& Jurisprudência, p. 1.

${ }^{249}$ DIREITO CIVIL. ACIDENTE DO TRABALHO. INDENIZAÇÃO. RESPONSABILIDADE CIVIL DO EMPREGADOR. NATUREZA. PRESERVAÇÃO DA INTEGRIDADE FÍSICA DO EMPREGADO. PRESUNÇÃO RELATIVA DE CULPA DO EMPREGADOR. INVERSÃO DO ÔNUS DA PROVA. A natureza da atividade é que irá determinar sua maior propensão à ocorrência de acidentes. O risco que dá margem à responsabilidade objetiva não é aquele habitual, inerente a qualquer atividade. Exige-se a exposição a um risco excepcional, próprio de atividades com elevado potencial ofensivo SUPERIOR TRIBUNAL DE JUSTIÇA. Revista Eletrônica de Jurisprudência. Disponível em: $<$ https://ww2.stj.jus.br/revistaeletronica/ita.asp?registro=200801364127\&dt_publicacao=25/06/2009>. Acesso em: 09 nov. 2012.
} 
de culpa, para os empregados é necessário exigi-la? Pablo Gagliano e Rodolfo Pamplona mencionam a contradição que existiria em admitir que o empregador, pela mesma atividade, respondesse de modo objetivo perante terceiros e subjetivamente em relação aos seus empregados 250 .

Para Celso Antônio Bandeira de Mello, as discriminações são compatíveis com a cláusula igualitária apenas e tão somente quando existe um vínculo de correlação lógica entre a peculiaridade diferencial acolhida por residente no objeto e a desigualdade de tratamento em função dela decorrida, desde que tal correlação não seja incompatível com interesses prestigiados na Constituição ${ }^{251}$.

Dessa maneira, não existe uma justificativa racional que permita exigir a presença do elemento culpa para conferir indenização nos casos de acidentes do trabalho e de prescindir de tal elemento dos terceiros. Na verdade, esse tratamento desigual colide com outros postulados constitucionais, haja vista que a ordem econômica é fundada na valorização no trabalho humano (artigo 170).

Outrossim, os direitos arrolados no artigo $7^{\circ}$ da Constituição são meramente exemplificativos, admitindo-se sua ampliação para melhorar as condições sociais do trabalhador.

Como é cediço, a responsabilidade objetiva é mais vantajosa ao empregado em razão de prescindir de prova do elemento culpa. Nesse sentido, já decidiu o Superior Tribunal de Justiça ${ }^{252}$. Também sob o argumento de que o caput do artigo $7^{\circ}$ da Constituição garante a inclusão de outros direitos aos trabalhadores, a I Jornada de Direito

${ }^{250}$ GAGLIANO, Paulo Stolze; PAMPLONA FILHO, Rodolfo. Novo curso de direito civil: responsabilidade civil. 4. ed. São Paulo: Saraiva, 2006. p. 246-247.

${ }^{251}$ MELLO, Celso Antônio Bandeira de. Conteúdo jurídico do princípio da igualdade. 3. ed. São Paulo: Malheiros Ed., 2002. p. 17.

${ }^{252}$ DIREITO CIVIL. ACIDENTE DO TRABALHO. INDENIZAÇÃO. RESPONSABILIDADE CIVIL DO EMPREGADOR. NATUREZA. PRESERVAÇÃO DA INTEGRIDADE FÍSICA DO EMPREGADO. PRESUNÇÃO RELATIVA DE CULPA DO EMPREGADOR. INVERSÃO DO ÔNUS DA PROVA. O art. $7^{\circ}$ da CF se limita a assegurar garantias mínimas ao trabalhador, o que não obsta a instituição novos direitos - ou a melhoria daqueles já existentes - pelo legislador ordinário, com base em um juízo de oportunidade, objetivando a manutenção da eficácia social da norma através do tempo.

- A remissão feita pelo art. $7^{\circ}, \mathrm{XXVIII}$, da $\mathrm{CF}$, à culpa ou dolo do empregador como requisito para sua responsabilização por acidentes do trabalho, não pode ser encarada como uma regra intransponível, já que o próprio caput do artigo confere elementos para criação e alteração dos direitos inseridos naquela norma, objetivando a melhoria da condição social do trabalhador.

- Admitida a possibilidade de ampliação dos direitos contidos no art. $7^{\circ}$ da $\mathrm{CF}$, é possível estender o alcance do art. 927, parágrafo único, do CC/02 - que prevê a responsabilidade objetiva quando a atividade normalmente desenvolvida pelo autor do dano implicar, por sua natureza, risco para terceiros - aos acidentes de trabalho. SUPERIOR TRIBUNAL DE JUSTIÇA, REsp 1.067.738 (200801364127) $3^{\mathrm{a}}$ Turma. Rel. Ministro Sidnei Benetti, rel. para acórdão Ministra Nancy Andrighi, j. 26/05/2009, DJU 25/06/2009. SUPERIOR TRIBUNAL DE JUSTIÇA. Revista Eletrônica de Jurisprudência. Disponível em: $<$ https://ww2.stj.jus.br/revistaeletronica/ita.asp?registro=200801364127\&dt_publicacao=25/06/2009>.

Acesso em: 09 nov. 2012. 
Material e Processual da Justiça do Trabalho elaborou o Enunciado ${ }^{\circ}$ 37, que prevê a aplicação da responsabilidade objetiva prevista no artigo 927, parágrafo único, do Código Civil aos acidentes do trabalho ${ }^{253}$.

A contrário da responsabilidade objetiva ambiental, que é fundada no risco integral e não tem o condão de romper o nexo causal, a objetiva decorrente do risco da atividade é baseada no risco mitigado, ou seja, à causalidade agrega-se uma característica especial, um dado qualificativo. Então, ao risco da atividade, Sergio Cavalieri Filho associa o dever de segurança e Claudio Luiz Bueno de Godoy adiciona a particularidade acima do normal $^{254}$. O risco mitigado admite as causas de afastamento do nexo causal que serão discutidas no item 3.3. infra.

Entretanto, compreende-se que essa cláusula geral de responsabilidade sem culpa do Código Civil somente veio reforçar a responsabilidade do empregador em casos de acidentes do trabalho prevista na Consolidação das Leis do Trabalho desde 1943.

\subsubsection{Responsabilidade objetiva pelo risco da atividade na Consolidação das Leis do Trabalho}

Raymond Saleilles e Louis Josserand conceberam a responsabilidade objetiva pela teoria do risco ${ }^{255}$. Risco é o perigo eventual mais ou menos previsível, diferentemente da álea (imprevisível) e do perigo (real). O risco é abstrato ${ }^{256}$. Dessa forma, aquele que exerce uma atividade deve-lhe assumir os riscos e indenizar os danos dela decorrentes.

Pietro Trimarchi preconizou a tese de que a responsabilidade objetiva fundada na distribuição dos riscos da empresa teria um caráter econômico de racionalização do mercado. O autor afirma que existiriam medidas idôneas para excluir os riscos, todavia, elas seriam excessivamente custosas em relação à probabilidade reduzida de causar danos

\footnotetext{
253“RESPONSABILIDADE CIVIL OBJETIVA NO ACIDENTE DE TRABALHO. ATIVIDADE DE RISCO. Aplica-se o art. 927, parágrafo único, do Código Civil nos acidentes do trabalho. O art. $7^{\circ}$, XXVIII, da Constituição da República, não constitui óbice à aplicação desse dispositivo legal, visto que seu caput garante a inclusão de outros direitos que visem à melhoria da condição social dos trabalhadores. ANAMATRA. I Jornada de Direito Material e Processual do Trabalho. Enunciado $n^{\circ}$ 37. Disponível em: $<$ http://www.anamatra.org.br/jornada/enunciados/enunciados_aprovados.cfm>. Acesso em: 19 nov. 2010.

${ }^{254}$ GODOY, Claudio Luiz Bueno de. op. cit., p. 115.

${ }^{255}$ Cf. SALEILLES, Raymond.op. cit., p. 6; JOSSERAND, Louis. La responsabilité du fait des choses inanimées. Paris: A. Rousseau, 1897, p. 104-105 Apud ROUAST, André; GIVORD, Maurice. op. cit., p. 21.

${ }^{256}$ LOPEZ, Teresa Ancona. op. cit., p. 16.
} 
e, consequentemente, somente a administração da empresa poderia avaliar a conveniência de adotar as práticas preventivas. Contudo, o montante indenizatório oneroso, que o juiz fixaria em cada caso concreto de acidente, constituiria um mecanismo de pressão econômica para efetivar a prevenção, pois, esse custo do dano agravaria eficazmente o passivo da empresa que, por via reflexa, seria induzida a novas pesquisas e novas descobertas de métodos e técnicas menos arriscadas ${ }^{257}$.

Entretanto, Guido Alpa e Mario Bessone questionam a eficácia da indenização dos danos como mecanismo apto para escolha empresarial de prevenção de danos. Dessa forma, esses autores propugnam uma intervenção do Estado, ou seja, um controle da atividade perigosa por decisivos instrumentos de prevenção disponíveis por normas de direito público ${ }^{258}$.

Na seara trabalhista, foi incorporada a teoria do risco proveito, na modalidade do risco profissional $^{259}$, que preconiza a responsabilidade daquele que tem, ainda que potencialmente, vantagem da atividade danosa. O empregador terá, como contraprestação dos benefícios que aufere, de suportar os danos que eventualmente atingem os empregados $^{260}$.

Roger Pirson e Albert de Villé dizem que aquele que tem lucro de sua iniciativa, deve sofrer as consequências desastrosas ${ }^{261}$.

A Consolidação das Leis do Trabalho prescreve, em seu artigo $2^{\circ}$, que o empregador é a empresa, individual ou coletiva, que, assumindo os riscos da atividade econômica, admite, assalaria e dirige a prestação pessoal de serviços.

Assim, o conceito jurídico de risco vincula o empregador pelos custos e resultados de sua atividade, além da própria álea de seu empreendimento. Dessa forma, essa responsabilidade estende-se aos empregadores que não exercem tipicamente uma atividade

\footnotetext{
${ }^{257}$ TRIMARCHI, Pietro. op. cit., p. 34-38.

${ }^{258}$ ALPA, Guido; BESSONE, Mario. La responsabilità civile. 2. ed. Milano: Giuffrè, 1980. v. 2, p. 145-148.

${ }^{259}$ Nesse trabalho procurou-se resgatar a noção de risco profissional utilizada por Saleilles para defender a responsabilidade objetiva do empregador prevista na CLT, com as adequações e exigências da sociedade contemporânea. Assim, exige-se que o empregador tenha vantagem para que possa responder pelos danos que o empregado foi submetido. SALEILLES, Raymond.op. cit., p. 6.

${ }^{260}$ NORONHA, Fernando. op. cit., v. 1, p. 509.

${ }^{261}$ PIRSON, Roger; VILLÉ, Albert de. Traité de la responsabilidade civile extra-contractuelle. Paris: Générale de Droit e de Jurisprudence, 1935. t. 2, p. 481.
} 
econômica, tal como os empregadores domésticos e aqueles que desenvolvam uma atividade de caráter beneficente ${ }^{262}$.

Ora, se o empregador assume os riscos da atividade econômica, que é gênero, assume os riscos de acidentes do trabalho, que é uma das espécies e, com efeito, deve indenizar os danos sofridos pelo empregado. Dessa forma, aqueles que realizam essas atividades colhem todos os proveitos e, por isso, devem suportar os ônus e os encargos dos riscos disseminados. A vítima necessita de segurança e não pode assumir as infelicidades alheias, uma vez que não participou das vantagens ${ }^{263}$.

Américo Plá Rodriguez afirma que o fato de o empregado pôr à disposição do empregador sua energia em troca de um determinado salário é um conteúdo estrutural da relação de emprego ${ }^{264}$.

Todavia, não se pode dizer que o Estado, ao criar o auxílio doença acidentário e o auxílio acidente, reconheceu implicitamente que este risco não seria suportado pelo empregador. Pelo contrário, por esses benefícios terem o caráter salarial, o Estado assumiu essa obrigação para não desamparar o trabalhador mutilado que só tem sua força de trabalho para a sobrevivência. A indenização complementar pelos danos sofridos pelo empregado são de responsabilidade do empresário, causador deles, que assume os riscos de seu empreendimento.

Assim, à medida que o seguro social do Estado abrange todos os fatos ocorridos nas dependências do lugar e durante a jornada de trabalho, que são os chamados acidentes do trabalho por equiparação, a indenização do empregador limita-se aos fatos que estão relacionados substancialmente ao exercício da empresa ${ }^{265}$.

Por isso, reconhece-se que o risco profissional é mitigado, pois ele está somente no fato material da própria empresa ${ }^{266}$. Dessa forma, as excludentes do nexo causal se aplicam.

\footnotetext{
${ }^{262}$ DELGADO, Maurício Godinho. op. cit., p. 394.

${ }^{263}$ LIMA, Alvino. op. cit., p. 119.

${ }^{264}$ PLÁ RODRIGUEZ, Américo. Princípios de direito do trabalho. 3. ed. São Paulo: LTr, 2004. p. 438.

${ }^{265}$ TRIMARCHI, Pietro. op. cit., p. 33.

${ }^{266}$ Id. Ibid., p. 24-25.
} 


\subsection{Nexo causal e as respectivas excludentes}

O nexo causal é o elemento da responsabilidade civil que busca descobrir o causador do dano.

Dessa maneira, Henri e Leon Mazeaud dizem que o nexo causal da responsabilidade subjetiva é o liame de causa e efeito entre a culpa e o dano, pois a culpa é a causa do prejuízo. Ao contrário, a responsabilidade objetiva pressupõe que o prejuízo seja resultado do fato do causador do dano (ação ou omissão) e, consequentemente, o nexo causal é a ligação de causa e efeito entre o fato e o dano ${ }^{267}$. Infere-se, então, que os irmãos Mazeaud mesclam a conduta com a própria culpa.

Para Sérgio Cavalieri Filho, nexo causal é o vínculo entre um determinado comportamento e um resultado, inferindo-se com base nas leis naturais, se a ação ou omissão do agente foi ou não a causa do dano ${ }^{268}$.

Desencadeado no mundo dos fatos o acidente do trabalho, é necessário averiguar se há um liame de causalidade entre o dano e o fato do empregador. Dessa forma, o nexo causal da responsabilidade civil é mais estreito que aquele previsto na responsabilidade acidentária, pois esta inclui situações não relacionadas diretamente ao exercício do trabalho, além do nexo técnico epidemiológico trazer presunções para certas doenças.

Essa diferença de tratamento decorre da distinção do bem jurídico protegido, ou seja, o caráter alimentar do benefício previdenciário e a indenização na responsabilidade civil. Por isso, não existe razão lógica para se aplicar o nexo técnico epidemiológico das doenças ocupacionais na responsabilidade civil do acidente do trabalho ${ }^{269}$.

A dificuldade se impõe quando há uma cadeia de condições, várias circunstâncias concorrendo para o evento danoso e precisa-se individualizar qual a causa real do resultado. Dentre as diversas teorias para explicar a causalidade jurídica, destacam-se duas, a saber: equivalência dos antecedentes ou das condições ou, ainda, conditio sine qua non e causalidade adequada. Cumpre registrar a existência de uma terceira teoria chamada de danos diretos e imediatos, como um amálgama das duas anteriores ${ }^{270}$.

\footnotetext{
${ }^{267}$ MAZEAUD, Jean; MAZEAUD, Leon. op. cit., t. 1, p. 346.

${ }^{268}$ CAVALIERI FILHO, Sérgio. op. cit., p. 71.

${ }^{269}$ Sobre as considerações do nexo técnico epidemiológico, remete-se o leitor ao item 2.1.1.2, no capítulo 2.

${ }^{270}$ SILVA, Wilson Melo da. Responsabilidade sem culpa. 2. ed. São Paulo: Saraiva, 1974. p. 114.
} 
A teoria da equivalência dos antecedentes, desenvolvida por von Buri, não faz distinção entre causa e condição e, por isso, todas as condições concorrem para o mesmo resultado, todas se equivalem na eficiência causal ${ }^{271}$. Critica-se essa teoria por levar ao regresso ao infinito e ferir até o sentimento de justiça ${ }^{272}$.

Em contrapartida, a teoria da causalidade adequada, elaborada originalmente por Von Bar e aprimorada por Kries, considera que quanto maior a probabilidade de que uma causa seja geradora de um dano, mais adequada ela seria para produzir o dano ${ }^{273}$. Ela difere causa de condição, pois causa é o antecedente adequado à produção do resultado. Portanto, nem todas as condições são causa, mas apenas aquela que é mais apropriada para produzir o evento. José de Aguiar Dias e Sérgio Cavalieri Filho dizem que essa teoria está em consonância com a lei brasileira ${ }^{274}$.

Entretanto, Agostinho Alvim sustenta que o Código Civil brasileiro adotou a teoria dos danos diretos ou imediatos, ou seja, o nexo causal é a relação imediata e direta de causa e efeito entre a inexecução da obrigação e o dano ${ }^{275}$. Nesse sentido, Wilson Melo da Silva destaca o princípio da necessariedade entre causa e dano, ou seja, a causa deve ser necessária ao dano ${ }^{276}$. Carlos Roberto Gonçalves também aduz que o legislador brasileiro adotou a teoria dos danos imediatos e diretos, pois imputou ao autor do dano somente as consequências diretas ${ }^{277}$.

Tanto a teoria da causalidade adequada quanto a dos danos diretos e imediatos buscam seu fundamento legal de validade no artigo 403 do Código Civil, que determinou que mesmo se a inexecução resultar de dolo do devedor, as perdas e danos só incluem os prejuízos efetivos e os lucros cessantes por efeito dela direto e imediato, isto é, a causa mais direta segundo o curso natural e ordinário das coisas.

Assim, enquanto a teoria da causalidade adequada reputa a causa determinante, segundo o curso natural e ordinário das coisas, para indenizar os danos, a teoria dos danos diretos e imediatos almeja a necessariedade da causa para esse fim indenizatório ${ }^{278}$.

\footnotetext{
${ }^{271}$ HUNGRIA, Nelson. Comentários ao Código Penal. 4. ed. Rio de Janeiro: Forense, 1958. p. 65.

${ }^{272}$ SILVA, Wilson Melo da. op. cit., p. 117.

${ }^{273}$ Id. Ibid., p. 119.

${ }^{274}$ DIAS, José de Aguiar. op. cit., v. 2, p. 349; CAVALIERI FILHO, Sérgio. op. cit., p. 73.

${ }^{275}$ ALVIM, Agostinho. Da inexecução das obrigações e suas consequências. 3. ed. Rio de Janeiro: Jurídica e Universitária, 1965. p. 331 e ss.

${ }^{276}$ SILVA, Wilson Melo da. op. cit., p. 131-132.

${ }^{277}$ GONÇALVES, Carlos Roberto. op. cit., p. 273.

${ }^{278}$ CAVALIERI FILHO, Sérgio. op. cit., p. 75-76.
} 
Como é notório, o acidente do trabalho típico traz o nexo causal bem nítido. A mera descrição do acidente leva à percepção do vínculo de causalidade do dano com a execução do contrato de trabalho. Por outro lado, as doenças ocupacionais exigem maior pesquisa, pois é difícil estabelecer se a enfermidade apareceu ou não do trabalho.

Devido aos entraves de estabelecer o nexo causal, o Conselho Federal de Medicina editou a Resolução 1488/98 que recomenda, em seu artigo $2^{\circ}$, os procedimentos e os critérios mais adequados para determinar ou não o nexo causal nas perícias médicas a respeito das doenças ocupacionais, dentre eles: a realização de exames complementares, a história clínica e ocupacional, o estudo do local de trabalho e de sua organização, dados epidemiológicos, literatura atualizada, verificação de quadro clínico ou subclínico em trabalhador exposto a condições agressivas, identificação de riscos físicos, químicos, biológicos, mecânicos, estressantes e outros, depoimento e experiência dos trabalhadores e os conhecimentos e as práticas de outras disciplinas e de seus profissionais, sejam ou não da área de saúde ${ }^{279}$.

Um outro ponto de destaque é que em um acidente do trabalho pode ocorrer a concausa, isto é, outra causa que se juntando à principal, concorre para o resultado. Tratase de circunstâncias que concorrem para o agravamento do dano, mas não excluem o nexo causal desencadeado pela conduta principal, nem de, por si sós, produzir o dano ${ }^{280}$. Essas causas podem ser antecedentes, concomitantes ou consequentes.

A doença fundada em causas múltiplas será caracterizada como ocupacional desde que, pelo menos, uma delas seja laboral e contribua diretamente para sua eclosão ou agravamento.

Por outro lado, com relação ao acidente típico, podem existir causas antecedentes, como um diabético que sofra um pequeno ferimento e, em consequência, venha a óbito. Para uma causa superveniente, tem-se um empregado lesionado que adquire complicação em virtude de bactérias patogênicas que lhe causam a morte. Somente se essa infecção foi exclusiva para a morte é que haverá rompimento do nexo causal anterior e ela será eleita em causa direta e imediata do novo dano, isto é, a origem de novo dano. Caso contrário, será uma causa que apenas contribuiu para o evento danoso.

\footnotetext{
${ }^{279}$ CONSELHO FEDERAL DE MEDICINA. Resolução 1.488, de 6 de março de 1998. Disponível em: <http://www.portalmedico.org.br/resolucoes/CFM/1998/1488_1998.htm>. Acesso em: 20 abr. 2012.

${ }^{280}$ CAVALIERI FILHO, Sérgio. op. cit., p. 84.
} 
Outrossim, existem as causas concomitantes que coexistem ao sinistro, como a perda auditiva decorrente da exposição excessiva a ruídos no ambiente laboral e, simultaneamente, o fator etário.

Finalmente, essa responsabilidade civil pode ser afastada pelo rompimento do nexo causal. As causas de exclusão do nexo causal são casos de impossibilidade superveniente de cumprimento da obrigação não imputáveis ao devedor (agente causador do dano).

Os acidentes do trabalho por equiparação demonstram que o nexo causal é indireto, ou seja, o ato é praticado por terceiro, pela própria vítima ou por motivo de caso fortuito ou força maior, no ambiente do trabalho ou em razão dele. Para fins previdenciários, existe a configuração do acidente e a concessão dos benefícios.

$\mathrm{Na}$ responsabilidade civil subjetiva, existirão as causas excludentes do nexo causal, pois o descumprimento das obrigações por fatos alheios à atividade empresarial não poderá ser imputado ao empregador. No entanto, na responsabilidade objetiva, o risco mitigado afasta o nexo causal e o integral não tem essa aptidão.

\subsubsection{Caso fortuito ou força maior}

O caso fortuito e a força maior excluem a responsabilidade do devedor, salvo se expressamente houver por eles se responsabilizado, nos termos do artigo 393 do Código Civil. Fala-se em caso fortuito ou força maior quando se trata de acontecimento que escapa a toda diligência, inteiramente estranho à vontade do agente. Apesar dos efeitos práticos serem os mesmos no caso fortuito e na força maior, é possível distingui-los.

Enquanto o caso fortuito é marcado pela imprevisibilidade, a força maior é registrada pela inevitabilidade. O caso fortuito é o evento imprevisível e, por isso, inevitável. Entretanto, força maior é o acontecimento inevitável, ainda que previsível, pois decorre de fato superior às forças do agente como, normalmente, são os fatos da natureza, como as tempestades, enchentes ${ }^{281}$. Um outro elemento distintivo entre caso fortuito e

\footnotetext{
${ }^{281}$ CAVALIERI FILHO, Sérgio. op. cit., p. 91.
} 
força maior é a causa originária desses acontecimentos, isto é, enquanto o caso fortuito tem a causa no próprio objeto, a força maior é proveniente de uma causa externa ${ }^{282}$.

Cumpre registrar que o artigo 501 da CLT define força maior como todo acontecimento inevitável, em relação à vontade do empregador, e para a realização do qual este não concorreu, direta ou indiretamente. O parágrafo primeiro enfatiza que a imprevidência do empregador exclui o motivo da força maior.

$\mathrm{Na}$ esfera da responsabilidade objetiva, se a indenização é devida pelo simples risco proveito, Agostinho Alvim somente exclui o nexo causal em caso fortuito externo ${ }^{283}$. Caso fortuito externo é aquele que não está vinculado à própria atividade do responsável pelo dano ${ }^{284}$. Ao contrário, o fortuito interno é aquele fato danoso imprevisível que está ligado à atividade do empregador e, assim, abrangido pelo conceito mais amplo do risco do negócio $^{285}$. Dessa forma, se o fato é imprevisível, mas seus efeitos evitáveis, cabe ao empregador adotar as medidas para tanto, sob pena de restarem configurados os pressupostos do nexo causal, viabilizando a indenização.

\subsubsection{Fato exclusivo da vítima}

A vítima pode ter um comportamento tal que seja a única causa do evento e, em decorrência, há a interrupção do nexo causal. O agente, aparente causador do dano, é apenas um instrumento do acidente. Dessa forma, o fato exclusivo da vítima é excludente do nexo causal na hipótese de a conduta do empregado ser causa única do acidente do trabalho, sem qualquer liame com o descumprimento das normas legais, contratuais, convencionais, regulamentares, técnicas ou do dever geral de cautela por parte do empregador.

Para ilustrar o fato exclusivo da vítima, Sebastião Geraldo de Oliveira cita o empregado que desliga o sensor de segurança automática de uma máquina perigosa e, em seguida, sofre acidente por essa conduta ${ }^{286}$. Na situação exposta, o empregado fará jus

\footnotetext{
${ }^{282}$ MAGALHÃES. José Maria Vilhena de. op. cit., p. 90.

${ }^{283}$ ALVIM, Agostinho. op. cit., p. 310.

${ }^{284}$ NORONHA, Fernando. op. cit., v. 1, p. 657.

${ }^{285}$ OLIVEIRA, Sebastião Geraldo. op. cit., p. 141.

${ }^{286}$ Id. Ibid., p. 138.
} 
somente ao benefício acidentário, cuja cobertura abrange até os acidentes praticados por culpa da vítima ou que tenham causalidade remota com o trabalho.

\subsubsection{Fato de terceiro}

Terceiro é qualquer pessoa além da vítima e do aparente causador do dano ${ }^{287}$. Dessa maneira, fato de terceiro é o ato ilícito praticado por alguém que não seja o acidentado, nem o empregador ou os seus prepostos. Eventuais atos praticados por terceiros e capitulados como acidentes do trabalho por equiparação somente são amparados pela Previdência Social e, não pela indenização civil. O lesado poderá postular indenização dos danos sofridos diretamente para o terceiro.

Mas, afinal, quais são os danos indenizáveis pelo empregador?

\subsection{Danos decorrentes do acidente do trabalho}

Henri e Leon Mazeaud afirmam que se a indenização é a essência da responsabilidade civil, é necessário ter algo a reparar. Dessa forma, o dano é elemento constitutivo da responsabilidade civil $^{288}$. Consequentemente, a indenização ${ }^{289}$ não tem o caráter de pena, mas de ressarcimento, de compensação ou de reparação ${ }^{290}$. Logo, a regra essencial para a indenização é que o dano seja certo ${ }^{291}$, ainda que a responsabilidade seja contratual e corresponda a inexecução de um dever contratual.

\footnotetext{
${ }^{287}$ DIAS, José de Aguiar. op. cit., v. 2, p. 299.

${ }^{288}$ MAZEAUD, Jean; MAZEAUD, Leon. op. cit., t. 1, p. 229.

${ }^{289}$ Carlos Roberto Gonçalves destaca que a Constituição Federal trouxe o vocábulo indenização como gênero, do qual, reparação e ressarcimento são espécies que se referem ao pagamento do dano moral e patrimonial, respectivamente. GONÇALVES, Carlos Roberto. op. cit., p. 279.

${ }^{290}$ OLIVEIRA, Sebastião Geraldo. op. cit., p. 179.

${ }^{291}$ Ao passo que dano certo é aquele prejuízo, econômico ou não, que é objeto de prova suficiente, tanto na verificação como em decorrência de determinado fato antijurídico, o dano eventual ou incerto é a aquele cujo prejuízo é duvidoso, meramente hipotético. Essa distinção tem relevância para a indenização dos danos provenientes da perda de uma chance. A perda de uma chance é a frustração da oportunidade de obter uma vantagem ou a frustração da oportunidade de evitar um dano, que por isso se verificou. Dessa forma, a "chance perdida" deverá gerar um dano certo para se obter a respectiva indenização. Cumpre, finalmente, dizer que esse dano originário da "chance perdida" poderá ser material ou moral. A divisão de dano moral e patrimonial será tratada no decorrer do texto. NORONHA, Fernando. op. cit., v. 1, p. 695-697.
} 
Do ponto de vista jurídico, Hans Albrecht Fischer diz que dano é o prejuízo sofrido pelo sujeito de direitos através da violação dos seus bens jurídicos, com exceção daquele que tenha ferido a si mesmo, pois seria juridicamente irrelevante ${ }^{292}$.

Cumpre ressaltar que Henri e Leon Mazeaud, apesar de afirmarem que a linguagem jurídica moderna emprega dano e prejuízo como expressões sinônimas, existe distinção entre elas. Enquanto dano provém da Lei Aquília e refere-se a lesão à integridade de alguma coisa, o prejuízo seria o resultado dessa lesão ${ }^{293}$.

Como é cediço, os acidentes do trabalho que causam a morte, a invalidez, a perda parcial da capacidade laborativa ou o afastamento prolongado geram danos aos empregados e, eventualmente, aos seus dependentes.

Um dos critérios de identificar os danos é o efeito da lesão, do caráter da repercussão sobre o lesado ${ }^{294}$. Um mesmo acidente pode acarretar danos em diversas esferas, desde o patrimônio até a dignidade humana. Classicamente, o dano que atinge o patrimônio do trabalhador recebe o título de dano patrimonial, conquanto aquele que não traz prejuízo ao seu patrimônio é nomeado de dano moral.

Todavia, Paulo Eduardo Vieira Oliveira critica essa dicotomia, pois, de acordo com essa classificação, o dano moral abarca toda lesão a aspecto não patrimonial da personalidade do indivíduo. Para esse doutrinador, o dano que lesa a integridade não patrimonial do indivíduo (aquele que fere algum direito de personalidade) deveria ser qualificado de pessoal e, por conseguinte, o dano moral seria apenas uma subespécie de dano pessoal que atingiu a integridade moral do trabalhador. Assim, o prejuízo causado a qualquer direito da personalidade, constituído de integridade psicofísica, intelectual, afetiva, social e moral, é um dano pessoal ${ }^{295}$.

Por fim, cumpre mencionar que Raimundo Simão de Melo trata o dano estético como um terceiro gênero autônomo de dano, não se confundindo com o dano patrimonial nem moral ${ }^{296}$. Consoante Teresa Ancona Lopez, dano estético é a lesão a um direito da

\footnotetext{
${ }^{292}$ FISCHER, Hans Albrecht. A reparação dos danos no direito civil. Trad. António de Arruda Ferrer Correia. Coimbra: Arménio Amado, 1938. p. 7.

${ }^{293}$ MAZEAUD, Jean; MAZEAUD, Leon. op. cit., t. 1, p. 229.

${ }^{294}$ Nessa dissertação, seguir-se-á a classificação proposta por Hans Albrecht Fischer na obra A reparação dos danos no direito civil, cit.

${ }^{295}$ OLIVEIRA, Paulo Eduardo Vieira. O dano pessoal no direito do trabalho. 2. ed. São Paulo: LTr, 2010. p. 31 e ss.

${ }^{296}$ MELO, Raimundo Simão de. op. cit., p. 376-381.
} 
personalidade - o direito à integridade física, especialmente, em seu aspecto externo, na imagem que se apresenta ${ }^{297}$.

Entretanto, o Superior Tribunal de Justiça (STJ) entende que o dano estético é abrangido pelo conceito de dano moral, embora tenha uma indenização apartada e cumulável com o dano moral, desde que as causas sejam inconfundíveis e passíveis de apuração em separado $^{298}$.

Essa posição jurisprudencial é negada por José Affonso Dallegrave Neto, que preconiza que é inadequado falar na acumulação do dano moral com o dano estético, haja vista que o dano estético importará, necessariamente, em dano material ou estará compreendido no conceito de dano moral ${ }^{299}$. Esse é também é o posicionamento da doutrinadora Teresa Ancona Lopez, que diz que dano estético é dano moral ${ }^{300}$.

O fundamento legal do dano estético é a parte final do artigo 949 do Código Civil de 2002, ao dispor que no caso de lesão ou outra ofensa à saúde, o causador do dano indenizará a vítima das despesas do tratamento e dos lucros cessantes até o fim da convalescença, além de algum outro prejuízo que o ofendido prove haver sofrido.

Sérgio Cavalieri Filho obtempera que o dano estético é uma modalidade de dano moral e se resume na questão de arbitramento. Considerando a gravidade e a intensidade do sofrimento, que se estende no tempo, o dano moral deve ser fixado em expressão de grande monta que represente a angústia da vítima pela deformidade física ${ }^{301}$.

Manter-se-á, então, a classificação dualista de dano moral e material, considerando o dano estético como uma espécie de dano moral.

\footnotetext{
${ }^{297}$ LOPEZ, Teresa Ancona. O dano estético: responsabilidade civil. 3. ed. São Paulo: Ed. Revista dos Tribunais, 2004. p. 64.

${ }^{298}$ Súmula 37 do Superior Tribunal de Justiça: "São cumuláveis as indenizações por dano material e moral oriundos do mesmo fato". SUPERIOR TRIBUNAL DE JUSTIÇA. Disponível em: <http://www.stj.jus.br/portal_stj/publicacao/engine.wsp?tmp.area=44>. Acesso em: 11 nov. 2012.

${ }^{299}$ DALLAGRAVE NETO, José Affonso. Responsabilidade civil no direito do trabalho. 4. ed. São Paulo: LTr, 2010. p. 175.

${ }^{300}$ LOPEZ, Teresa Ancona. O dano estético: responsabilidade civil, cit., p. 21.

${ }^{301}$ CAVALIERI FILHO, Sérgio. op. cit., p. 124.
} 


\subsubsection{Dano material}

O dano material é aquele que gera prejuízo financeiro à vítima e, consequentemente, uma diminuição do seu patrimônio atual ou futuro, avaliável monetariamente. O patrimônio é o conjunto de bens economicamente úteis que se encontram na esfera de disponibilidade do sujeito de direitos. Então, o dano se estabelece com o confronto entre o patrimônio realmente existente após o sinistro e o que possivelmente existiria se o evento não se tivesse produzido ${ }^{302}$.

Em regra, os efeitos do ato danoso incidem sobre o patrimônio atual, com sua diminuição, configurando o dano positivo ou emergente. Não obstante, os efeitos podem se produzir em relação ao futuro, impedindo ou diminuindo o benefício patrimonial a ser deferido à vítima. Tem-se, então, o lucro cessante que é aquilo que o lesado razoavelmente deixou de ganhar.

No caso de acidentes do trabalho, compete à vítima ou a seus dependentes relacionar para fins de ressarcimento toda despesa efetiva que tenha se realizado em razão do infortúnio, com o escopo de obter o ressarcimento integral do patrimônio anterior ao evento $^{303}$.

Em contrapartida, o lucro cessante se liga a elementos flutuantes, em face da incerteza que sempre domina quem trabalha com dados imaginários. O critério que deverá condicionar o lucro cessante é uma probabilidade objetiva resultante do desenvolvimento normal dos acontecimentos conjugados às circunstâncias peculiares ao caso concreto ${ }^{304}$. $\mathrm{O}$ trabalhador acidentado poderá incluir a título de lucros cessantes a perda de ganhos futuros em razão da incapacidade permanente para o trabalho.

O ressarcimento do dano material poderá ser: a) natural ou específico; b) indenização pecuniária. O melhor sistema é aquele da reparação específica, contudo, a indenização em dinheiro se legitima, haja vista que o dano patrimonial acarreta uma diminuição do patrimônio.

\footnotetext{
${ }^{302}$ DIAS, José de Aguiar. op. cit., v. 2, p. 344-345.

${ }^{303}$ OLIVEIRA, Sebastião Geraldo. op. cit., p. 182.

${ }^{304}$ DIAS, José de Aguiar. op. cit., v. 2, p. 349.
} 


\subsubsection{Dano moral}

O conceito de dano moral possui uma face negativa e outra positiva. Pelo lado negativo, José de Aguiar Dias argumenta que "quando ao dano não correspondem as características do dano patrimonial, dizemos que estamos em presença do dano moral ${ }^{305, "}$ Nessa linha já tinha se manifestado o autor alemão Hans Albrecht Fischer, ao estabelecer que a qualidade deles é não serem danos patrimoniais ${ }^{306}$.

Porém, outra corrente liderada pelos irmãos Mazeaud vincula o dano moral como aquele que causa uma dor moral à vítima ${ }^{307}$.

Hodiernamente, Sergio Cavalieri Filho diz que o dano moral, em sentido estrito, é a violação do direito à dignidade. Sob essa perspectiva, o dano moral não está vinculado à reação psíquica da vítima, haja vista que é possível a ocorrência de ofensa à dignidade da pessoa humana sem dor, vexame, sofrimento. Essa dignidade humana é integrada de um conjunto de bens imateriais que formam sua personalidade. Por isso, pode-se também afirmar que dano moral, em sentido amplo, é a violação dos direitos da personalidade, abrangendo todas as ofensas à pessoa, considerada em sua dimensão individual e social ${ }^{308}$.

Por conseguinte, a melhor nomenclatura seria dano pessoal, adotada por Paulo Eduardo Vieira Oliveira, na qual o aspecto moral seria apenas um aspecto atingido.

A reparabilidade do dano moral foi, inicialmente, questionada pelas seguintes razões: a) falta de efeito penoso durável, b) incerteza do direito violado, c) dificuldades em descobrir a existência do dano moral, d) indeterminação do número de pessoas lesadas, e) impossibilidade de rigorosa avaliação em dinheiro, f) imoralidade da compensação da dor com o dinheiro e g) extensão do arbítrio concedido ao juiz ${ }^{309}$.

Mas, em seguida, admitiu-se a reparação do dano moral com uma função satisfatória, ou seja, busca-se um bem que recompense o sofrimento e a humilhação sofrida ${ }^{310}$.

\footnotetext{
${ }^{305}$ DIAS, José de Aguiar. op. cit., v. 2, p. 357.

${ }^{306}$ FISCHER, Hans Albrecht. op. cit., p. 230.

${ }^{307}$ MAZEAUD, Jean; MAZEAUD, Leon. op. cit., t. 1, p. 318.

${ }^{308}$ CAVALIERI FILHO, Sérgio. op. cit., p. 101-102.

${ }^{309}$ DIAS, José de Aguiar. op. cit., v. 2, p. 367.

${ }^{310}$ No Brasil, o grande defensor da reparabilidade do dano moral foi Pedro Lessa. Cf. SUPREMO TRIBUNAL FEDERAL. Memória Jurisprudencial Ministro Pedro Lessa. Brasília: Coordenadoria de Divulgação de Jurisprudência, 2007. p. $138 . \quad$ Disponível em: $<$ http://www.stf.jus.br/portal/cms/verTexto.asp?servico=publicacaoPublicacaoInstitucionalMemoriaJurispr ud>. Acesso em: 11 nov. 2012.
} 
Paralelamente à função satisfatória, também é necessário impor uma pena ao causador do dano moral para não passar impune e, por conseguinte, cometer novas infrações $^{311}$. Assim, Raimundo Simão de Melo diz que a natureza da reparação do dano moral é tríplice: reparatória/satisfativa, sancionatória/punitiva e admoestativa/preventiva ${ }^{312}$.

A reparabilidade do dano moral é assegurada constitucionalmente, no Brasil, por força do artigo $5^{\circ}$, incisos $\mathrm{V}$ e $\mathrm{X}$, que determinam, respectivamente, o direito de resposta proporcional ao agravo e a inviolabilidade da intimidade, da vida privada, da honra e da imagem das pessoas, assegurado o direito de indenização pelo dano moral e pelo material decorrente da violação de tais direitos.

Tecnicamente, toda a celeuma é originária da diferença entre pena e indenização, pois esta se ocupa em reparar o dano e aquela visa à culpa do causador e é inseparável dessa pessoa. À medida que a pena é o efeito do delito, a indenização é um dos diversos resultados do ato ilícito que gera danos a outrem.

José de Aguiar Dias destaca outras diferenças entre os dois institutos: a) a indenização não seria transmissível aos herdeiros se tivesse caráter penal; b) o irresponsável não está sujeito a pena, mas sim, à indenização; c) a pena pode ser convertida em outro castigo se o responsável não a satisfizer, ao contrário da indenização, que sempre subsiste. Dessa forma, o pagamento de uma soma pecuniária em caso de dano moral será um lugar intermediário entre a indenização e a pena, pois, simultaneamente, representa uma prestação imposta a favor do lesado e implica um mal ao indenizante ${ }^{313}$.

Apesar dessas distinções entre pena e indenização, a teoria dos danos punitivos ou punitive damages, adotada nos Estados Unidos da América, preconiza que a responsabilidade civil tem uma função reparatória e também preventiva, pois é imposto ao causador do dano, em razão da gravidade de sua conduta, um montante que ultrapassa o prejuízo do lesado, pois o dano estende-se além da dimensão individual e atinge toda a sociedade. Por isso, os danos punitivos são uma manifestação da pena privada, com o escopo de dissuadir o causador do dano dessas práticas lesivas ${ }^{314}$.

\footnotetext{
${ }^{311}$ CAVALIERI FILHO, Sérgio. op. cit., p. 103.

${ }^{312}$ MELO, Raimundo Simão de. op. cit., p. 359.

${ }^{313}$ DIAS, José de Aguiar. op. cit., v. 2, p. 366.

${ }^{314}$ LOURENÇO, Paula Meira. Os danos punitivos. Revista da Faculdade de Direito da Universidade de Lisboa, Coimbra, v. 43, n. 2, p. 1075-1076, 2002.
} 
Para a obtenção dessa indenização exemplar no direito dos Estados Unidos, é necessário o preenchimento de determinados requisitos, a saber: a) dolo ou culpa grave do causador do dano que, por sua vez, locupleta-se da vulnerabilidade econômica da vítima; b) julgamento por júri popular; e c) envolvimento de danos materiais e extrapatrimoniais $^{315}$.

No Brasil, a aplicação da teoria dos danos punitivos só é possível para a indenização do dano moral, haja vista que essa reparabilidade tem dupla função: pena para o culpado e satisfação para a vítima ${ }^{316}$. O artigo 944, parágrafo único, do Código Civil faculta ao juiz o uso da equidade para fixar a indenização na hipótese de se caracterizar a desproporção entre a gravidade da culpa e a extensão do dano. A IV Jornada de Direito Civil organizada pelo Conselho da Justiça Federal corrobora a existência dos danos punitivos no direito pátrio ${ }^{317}$.

A configuração do dano moral opera-se com a agressão à dignidade humana que fuja da normalidade e interfira intensamente no comportamento psicológico do indivíduo, causando-lhe angústia, aflições e desequilíbrio em seu bem-estar. O mero aborrecimento, irritação, dissabor do cotidiano não têm o condão de caracterizar o dano moral, sob pena de banalizá-lo.

O dano moral não se prova em si mesmo, uma vez que a violação à dignidade humana é indemonstrável por documentos, depoimentos, perícias ou quaisquer outros meios de prova. Por isso, o dano moral existe in re ipsa e deriva do próprio fato ofendido, de modo que provada a ofensa, ipso facto, está demonstrado o dano moral por força da presunção natural que decorre das regras da experiência comum ${ }^{318}$.

A reparabilidade do dano moral decorrente de acidente do trabalho é cabível nas seguintes hipóteses: morte do empregado em favor dos familiares e lesões corporais e doenças ocupacionais em favor da própria vítima.

Em caso de óbito do empregado no acidente do trabalho, os familiares com vínculo de afetividade podem pleitear o pagamento da soma pecuniária pelos danos

\footnotetext{
${ }^{315}$ LOPEZ, Teresa Ancona. Princípio da precaução e evolução da responsabilidade civil, cit., p. 81-82.

${ }^{316}$ Id. Ibid., p. 82.

${ }^{317}$ Enunciado 379: “O art. 944, caput do Código Civil não afasta a possibilidade de conhecer a função punitiva ou pedagógica da responsabilidade civil”. CONSELHO DA JUSTIÇA FEDERAL. IV Jornada de Direito Civil. Enunciado 379. Disponível em: <http://www.jf.jus.br/cjf/CEJ-Coedi/jornadascej/enunciados-aprovados-da-i-iii-iv-e-v-jornada-de-direito-civil/jornadas-de-direito-civil-enunciadosaprovados>. Acesso em: 11 nov. 2012.

${ }^{318}$ CAVALIERI FILHO, Sérgio. op. cit., p. 108.
} 
sofridos pela ausência permanente do ente querido. Assim, não é hereditariedade, pois o montante perseguido é em nome próprio pelo dano indireto ${ }^{319}$ causado à pessoa que sofreu o dano moral pela morte da vítima. O ponto de partida para identificar as pessoas que mantinham vínculo afetivo com a vítima é o núcleo familiar. Os cônjuges, companheiros, filhos e pais são presumivelmente vinculados com a vítima e, com sua morte, eles experimentam sentimento de dor, de pesar, de saudade, em virtude da ausência do ente querido. Assim, se as pessoas que conviviam afetivamente com o de cujus sofrerem com sua ausência, podem pedir danos morais por direito próprio.

É possível, também, a vítima falecer posteriormente ao acidente, em razão ou não dele. Se a demanda já tiver sido ajuizada com pedido de danos morais pelas lesões até então efetivadas na ocasião da morte do acidentado, haverá a habilitação dos herdeiros que receberão o valor arbitrado pelo juiz como integrante do espólio. Entrementes, se a demanda não tiver sido ajuizada, o inventariante poderá exercer o direito de ação para pedir o respectivo pagamento que irá compor o espólio do falecido, desde que este tivesse sentido o dano moral. Nessas situações, não há transmissibilidade do dano moral e, sim, direito sucessório. A morte extingue a personalidade e não o dano consumado, nem o direito à reparabilidade.

Todas essas demandas são processadas e julgadas pela Justiça do Trabalho porque decorrem de ato praticado pelo empregador em razão de relação de trabalho (artigo 114 da Constituição Federal).

Os parâmetros que deve o juiz fixar a título de dano moral são: a extensão do dano e a equidade (artigo 944 do Código Civil). Assim, o critério tarifário previsto no Código Brasileiro das Telecomunicações e na Lei de Imprensa não deve ser aplicado após a Constituição de 1988, inclusive, com posição sumulada do Superior Tribunal de Justiça que afasta essa orientação ${ }^{320}$.

\footnotetext{
${ }^{319}$ Dano indireto é aquele prejuízo sofrido por uma pessoa em reflexo de um dano causado a outrem. GONÇALVES, Carlos Roberto. op. cit., p. 278.

${ }^{320}$ Súmula 281 do Superior Tribunal de Justiça: “A indenização por dano moral não está sujeita a tarifação prevista na Lei da Imprensa". SUPERIOR TRIBUNAL DE JUSTIÇA. Súmula 281. Disponível em: $<$ http://www.stj.jus.br/portal_stj/publicacao/engine.wsp?tmp.area=368\&tmp.texto=74914\&tmp.area_anteri or $=44 \&$ tmp.argumento_pesquisa $=\mathrm{s} \% \mathrm{FAmula} \% 20281>$. Acesso em: 11 nov. 2012. Nesse sentido, o Supremo Tribunal Federal declarou como não recepcionado pela Constituição de 1988 todo o conjunto de dispositivos da Lei de Imprensa (Lei 5250/97). SUPREMO TRIBUNAL FEDERAL. ADPF 130. Rel. Min. Ayres Britto, j. 30/04/2009, Plenário, DJE de 06/11/2009. Disponível em: <http://www.stf.jus.br/portal/constituicao/artigo.asp\#ctx1>. Acesso em: 22 nov. 2012.
} 
O julgador deve ter como norte a razoabilidade e atender a dois motivos, quais sejam: que o montante seja uma punição ao infrator e, paralelamente, seja um importe suficiente à vítima para uma satisfação sua de qualquer espécie que não constitua um enriquecimento sem causa ${ }^{321}$. Dessa forma, o caráter recompensador da vítima deverá observar sua necessidade pessoal, a gravidade do ato e a magnitude do dano. Já, a faceta sancionatória deverá focar a capacidade econômica do agente.

Então, configurado o nexo causal entre o dano sofrido pelo empregado e o evento relacionado ao trabalho desenvolvido, surge a seguinte indagação: como garantir a indenização integral da vítima, sem se descuidar das normas de saúde e de segurança na empresa?

${ }^{321}$ CAVALIERI FILHO, Sérgio. op. cit., p. 116. 


\section{INTEGRAÇÃO DA CULPA E DO RISCO}

\subsection{Conceito de integração}

Integração, do latim integratione, ato ou efeito de integrar-se. Integrar-se, por sua vez, é tornar inteiro: completar, inteirar, integralizar ${ }^{322}$. Integrar é fazer-se inteiro, incluído num só todo ou conjunto ${ }^{323}$.

Demonstrar-se-á, a seguir, completude da responsabilidade civil dos acidentes do trabalho pela junção da culpa e do risco da atividade empresarial por meio do seguro privado.

\subsubsection{Integração da culpa e do risco}

A responsabilidade objetiva para os acidentes do trabalho decorre do próprio artigo $2^{\circ}$ da Consolidação das Leis do Trabalho (CLT), haja vista que atribuídos ao empregador os ônus de sua atividade. Esse dispositivo celetista foi recepcionado pela Constituição Federal de 1988 que, por seu turno, fixou os direitos sociais trabalhistas em uma cláusula aberta, no caput do artigo $7^{\circ}$, ao admitir outros direitos que visem à melhoria da condição social dos trabalhadores. Dessa forma, a fixação da responsabilidade objetiva em casos de acidentes do trabalho é mais favorável ao empregado que a subjetiva, pois esta exige a comprovação da culpa.

A adoção da responsabilidade sem culpa enseja a multiplicação das indenizações das vítimas. Contudo, para não desestimular a produção de riquezas pelos altos custos desses pagamentos, o inciso XXVIII do artigo $7^{\circ}$ da Constituição previu um seguro, a ser realizado pelo empregador, em favor do empregado para os casos de acidentes do trabalho, no intuito de que este tenha sua indenização garantida por uma seguradora, com fundamento no risco profissional.

\footnotetext{
${ }^{322}$ FERREIRA, Aurélio Buarque de Holanda. op. cit., p. 1169.

${ }^{323}$ AULETE, Caldas. iDicionárioAulete. Disponível em: <http://aulete.uol.com.br/integrar>. Acesso em: 14 dez. 2012.
} 
Consoante Wilson Melo da Silva, o seguro confere, ao causador do dano, o direito de não ter suas atividades cerceadas; e, à vítima, a certeza de indenização, pois se afasta a possível insolvência do agente ${ }^{324}$.

Cleber Lúcio de Almeida preconizou que a Constituição Federal de 1988 conferiu aos trabalhadores o direito ao seguro privado, custeado pelo empregador, como um complemento do seguro social, sob o argumento de que a indenização do seguro social é limitada, e o trabalhador tem direito à inteira indenização pelos danos decorrentes de acidente do trabalho. No seu entender, a cobertura do risco de acidente do trabalho pelo regime geral da previdência social é custeada, também, pelos trabalhadores e, por isso, esse seguro previsto constitucionalmente no artigo $7^{\circ}$, inciso XXVIII não poderia ser fundamento do social, uma vez que a obrigação prevista nessa regra seria apenas do empregador $^{325}$.

Em que pese aos conteúdos expostos, entende-se que o artigo $7^{\circ}$, inciso XXVIII, da Constituição constitui sustentáculo de seguro contra os acidentes do trabalho, sem qualquer distinção entre seguro social e privado. De início, pode-se justificar que o artigo $7^{\circ}$ arrolou direitos sociais de natureza previdenciária, como o seguro-desemprego (inciso II), aposentadoria (inciso XXIV), havendo, então, coerência em afirmar que uma das facetas do seguro previsto no artigo ora em comento fosse social.

Outrossim, pode-se aduzir que o texto constitucional, ao estabelecer que o seguro é a cargo do empregador, não excluiu outros entes da participação nesse instituto, apenas enfatizou o dever de o empregador efetivar o seguro social e o privado, haja vista que ele é o responsável pela atividade apta a causar danos.

Cleber Lúcio de Almeida embasa o seguro social apenas nos artigos $6^{\circ}$ e 201, inciso I, da Constituição que se referem à previdência como um direito social do trabalhador, que atenderá à cobertura dos eventos de doença, invalidez, morte e idade $\operatorname{avançada~}^{326}$.

Apesar de os acidentes do trabalho incluírem as doenças ocupacionais e ocasionarem invalidez e até a morte, ressalva-se que, nesses preceitos da previdência social, a Constituição em vigor não elegeu, expressamente, o seguro contra acidentes do

\footnotetext{
${ }^{324}$ SILVA, Wilson Melo da. op. cit., p. 170.

${ }^{325}$ ALMEIDA, Cleber Lúcio de. Responsabilidade civil do empregador e acidente de trabalho. Belo Horizonte: Dey Rey, 2003. p. 59-63.

${ }^{326}$ Id. Ibid., p. 61.
} 
trabalho como um risco social que ensejasse a proteção do Estado, ao contrário das Constituições de 1934 e 1969. Conforme já se demonstrou, todos os textos constitucionais que não trouxeram o seguro contra acidentes do trabalho incluído na previdência despertaram controvérsias a respeito de sua obrigatoriedade ${ }^{327}$.

Então, reconhece-se que a inclusão do seguro contra acidente do trabalho no regime de previdência social depende de uma interpretação sistemática entre os artigos 201, inciso I, e o $7^{\circ}$, inciso XXVIII, da Constituição, uma vez que foi esta última regra que impôs ao empregador o seguro contra acidentes do trabalho, sem excluir outros participantes nesse financiamento.

Embora o seguro social seja custeado pelos trabalhadores, tomadores de serviços e poder público, a legislação previu uma contribuição social adicional, exclusivamente, a cargo do empregador, com o escopo de cobrir os eventos resultantes de acidentes do trabalho. Então, esse pagamento do seguro do acidente do trabalho recebe um aporte adicional somente dos empregadores, conforme o risco que criaram ${ }^{328}$. O inciso XXVIII do artigo $7^{\circ}$ da Constituição Federal vem apenas reforçar que o empregador terá uma obrigação maior pelos riscos que deve assumir em virtude das vantagens obtidas por sua atividade econômica.

Dessa modo, entende-se que edificar o seguro social de acidente do trabalho sem menção ao artigo $7^{\circ}$, inciso XXVIII representa um retrocesso social, pois essa concepção confere espaço para interpretação de que a previdência social não cobriria o risco de acidente do trabalho devido à falta de previsão constitucional e, por conseguinte, a contribuição social adicional não teria alicerce para a cobrança. Além disso, essa explicação culminaria em restringir a proteção ao trabalhador acidentado apenas ao seguro privado.

Conquanto o seguro seja uma das manifestações da coletivização da responsabilidade civil em virtude de garantir a indenização ao empregado lesado e, simultaneamente, aliviar o dever do responsável ${ }^{329}$, ele tem, em contrapartida, um efeito perverso que é o desaparecimento do responsável por detrás do seguro. O segurador é

\footnotetext{
${ }^{327}$ Remete-se o leitor ao capítulo 2, item 2.2.3. supra em que se discorreu sobre a evolução do seguro de acidente do trabalho na legislação pátria e sua obrigatoriedade.

${ }^{328}$ Sobre o financiamento do seguro social no Brasil conferir capítulo 2, item 2.2.3.1. supra.

${ }^{329}$ NORONHA, Fernando. op. cit., v. 1, p. 568.
} 
quem desembolsará a indenização e, consequentemente, a responsabilidade perde sua função de prevenção de danos ${ }^{330}$.

Dessa forma, não é suficiente o empregador pagar o seguro e descuidar-se de tomar as medidas preventivas para evitar o sinistro. Assim, o inciso constitucional prossegue em sua segunda parte e acrescenta que o empregador não está excluído de responder na hipótese de incorrer em dolo ou em culpa.

Essa exposição está em consonância com o novo paradigma que é a segurança, emergindo o princípio da precaução no instituto da responsabilidade civil.

Para Teresa Ancona Lopez, princípio da precaução é aquele referente aos rumos e aos valores do sistema de previsão de riscos hipotéticos, coletivos ou individuais, que assustam a comunidade ou os indivíduos isoladamente com danos graves e irreversíveis e sobre os quais não há certeza científica. O princípio da precaução requer a adoção de medidas drásticas e eficazes com o fim de antecipar o risco suposto e possível, mesmo em face da incerteza ${ }^{331}$.

Esse princípio genuíno do Direito Ambiental é incorporado ao instituto da responsabilidade civil, uma vez que se tivessem sido realizadas as medidas preventivas, o dano teria sido evitado ${ }^{332}$. Logo, o substancial é impedir a ocorrência desses danos, concretizando a proteção e a segurança aos cidadãos em uma sociedade caracterizada por riscos mais graves.

Sabe-se que a ideia central de toda a responsabilidade civil é da proibição de causar dano a outrem, tendo-se como premissa que a etimologia da palavra responsabilidade remete a respondere que, por seu turno, vem de spondere, que significa prometer. Logo, a responsabilidade é "fazer o que se prometeu" e traz no seu bojo a garantia das consequências dos acontecimentos, que é, de modo geral, a indenização em dinheiro, sem excluir o ressarcimento in natura, quando as coisas devem retornar ao status quo ante, ou outros tipos de atos de reparação, como o desagravo pela imprensa por atos ilícitos contra a honra.

\footnotetext{
${ }^{330}$ NORONHA, Fernando. op. cit., v. 1, p. 572.

${ }^{331}$ LOPEZ, Teresa Ancona. Princípio da precaução e evolução da responsabilidade civil, cit., p. 103.

${ }^{332} \mathrm{~A}$ interiorização do princípio da precaução na responsabilidade civil possui resistência por alguns doutrinadores, dentre eles, DALLARI, Sueli Gandolfi; VENTURA, Deisy de Freitas Lima. O princípio da precaução, dever do Estado ou protecionismo disfarçado? São Paulo em Perspectiva, São Paulo, v. 16, n. 2, 2002.
} 
Entretanto, a responsabilidade não se resumiria à indenização de danos, mas também a prevenção e a precaução dos eventos danosos.

Essa responsabilidade preventiva é fundada na culpa, ou seja, o culpado é aquele que não observou as obrigações de prudência e de diligência nas situações de incerteza e de dúvida. A culpa é um mecanismo de prevenção dos danos, uma vez que os custos dos riscos não evitados serão absorvidos pelo passivo da empresa. Assim, a pressão econômica induz a empresa a novas pesquisas e descobertas de métodos produtivos menos arriscados ${ }^{333}$.

Propõe-se, então, que o critério da culpa não seja exclusivo, e sim integrativo com o risco da empresa em um sistema misto. Se por um lado a responsabilidade objetiva tutela melhor os interesses econômicos das vítimas, a responsabilidade preventiva almeja uma maior diligência do empregador, que passa a ter uma conduta mais adequada.

Portanto, a Constituição estabeleceu que a responsabilidade objetiva, prevista na CLT para os acidentes do trabalho, seja também garantida por meio de um seguro privado, que indenizará os eventuais danos sofridos. Simultaneamente, o empregador deve observar o princípio da precaução no meio ambiente do trabalho e evitar os infortúnios.

Nos casos em que o empregador agir com dolo ou culpa, entende-se que será responsabilizado por meio de demanda regressiva proposta pela seguradora.

Tem-se, então, a integração entre a culpa e o risco.

Assim, à medida que a responsabilidade objetiva visa à indenização de danos pelo risco profissional, a responsabilidade preventiva tem por finalidade a antecipação dos riscos para que eles não se efetivem. Esse fortalecimento da culpa com a adoção do princípio da precaução não significa um recuo da teoria do risco, mas sua própria evolução.

A avaliação da culpa deverá ser objetiva ou in abstrato, ou seja, deve ter como parâmetro o comportamento que um gestor diligente teria, sem considerar as intenções em comportamentos faltosos. Dentre os deveres de diligência, está o dever de informação que é fundamental na responsabilidade dos empregadores. Pelo princípio da precaução, os causadores de danos são impedidos de se utilizarem da incerteza científica como causa exonerativa ou justificativa dos danos provocados por suas decisões. Assim, para a responsabilização do empregador, é necessária a averiguação de sua conduta no monitoramento dos riscos hipotéticos (precaução) e dos riscos provados (prevenção).

\footnotetext{
${ }^{333}$ TRIMARCHI, Pietro. op. cit., p. 38.
} 
Essa "culpa de precaução" será analisada pelos padrões exigidos para cada tipo especial de atividade, isto é, o modelo de conduta exigido é aquele do empreendedor responsável em evitar riscos graves e irreversíveis. O substrato que fundamenta essa conduta é a obrigação de segurança que tem como desmembramentos: o dever de cuidado, a diligência em contratar pesquisas e perícias técnicas, o cumprimento do dever de informar-se a respeito dos riscos e também de informar todos os empregados que almejam que os danos irreversíveis não aconteçam, com a total transparência.

O desrespeito ao princípio da precaução é considerado um "defeito de precaução", que é alicerçado na culpa presumida do empregador responsável. Essa presunção de culpa iuris tantum completa a noção de dever de cuidado e de prudência que deve haver na relação de emprego da sociedade contemporânea. Está-se diante de comportamentos faltosos, e não de indenização de danos. Processualmente, haverá inversão do ônus da prova e o empregador deverá provar que agiu com cautela ou que tomou todas as medidas para que o pior não se realizasse.

Essa interpretação indicada para o artigo $7^{\circ}$, inciso XXVIII, da Constituição tem como paradigma o próprio seguro social centralizado pelo Estado por meio da autarquia previdenciária, haja vista que também por determinação constitucional a cobertura do acidente do trabalho será atendida concorrentemente pelo regime geral da previdência e pelo setor privado (artigo 201, § 10).

Então, o seguro privado reunirá a responsabilidade objetiva do empregador pelo risco da atividade com a responsabilidade subjetiva, consubstanciada na culpa ou no dolo de sua conduta no tocante às normas de segurança e de medicina do trabalho. Dessa forma, a garantia de indenização do empregado está atrelada à adoção de medidas preventivas para se evitar o evento danoso.

\subsection{Seguro privado e suas modalidades}

A finalidade do seguro privado é atenuar os efeitos economicamente danosos de eventos futuros e incertos que destruam as utilidades ou impeçam a produção de utilidades futuras. O seguro permite a propagação desses efeitos, com a difusão dos riscos que são suportados por duas ou mais pessoas. Logo, o fim superior do seguro privado também é a 
previdência e, do ponto de vista do segurado, não existe espaço para o lucro, isto é, ele não pode tirar proveito de um sinistro.

José Maria Vilhena Barbosa de Magalhães define seguro como resultado da solidariedade e da economia e, tendo o objetivo de previdência, o seguro é a instituição econômica pelo qual um indivíduo, mediante uma prestação, pretende ser compensado das consequências danosas que possa a ser acometido, em razão de eventos futuros e incertos ${ }^{334}$.

Não somente como instituição econômica, mas também revestida de juridicidade, o contrato de seguro é o negócio jurídico pelo qual o segurador se vincula, mediante o pagamento de prêmio, a ressarcir ao segurado, dentro do limite que se convencionou, os danos produzidos por sinistro, ou a prestar capital ou renda diante de determinado fato, concernente à vida humana ou ao patrimônio ${ }^{335}$. No contrato de seguro pré-elimina-se a álea $^{336} \mathrm{e}$, por isso, alude-se à função de previdência. A pessoa que quer eliminar sua álea econômica presta o que se chama de prêmio, ao passo que a outra vincula-se à cobertura, conferindo-lhe segurança ao primeiro contraente ao assumir o dever de afastar o que se temia.

Esse é o conceito originário de seguro alicerçado pelo tripé: risco, prêmio e indenização. Cesare Vivante exigiu, para a caracterização do contrato de seguro, a forma empresarial do segurador ${ }^{337}$. Nesse sentido, Fran Martins diz que contrato de seguro é aquele em que uma empresa admite indenizar os danos sofridos por outrem, em razão de evento incerto, mediante o pagamento de determinada quantia ${ }^{338}$.

Assim, entende-se por seguro privado um contrato pelo qual uma empresa aceita a suportar os prejuízos sofridos por outrem, em decorrência de um acontecimento aleatório, mediante o recebimento de um montante em dinheiro, ou seja, de um prêmio.

A indenização é uma obrigação condicional $^{339}$ assumida pelo segurador no momento da conclusão do negócio jurídico do seguro ${ }^{340}$. O prêmio é a primeira prestação feita pelo segurado ou pelo estipulante do contrato ao segurador.

\footnotetext{
${ }^{334}$ MAGALHÃES. José Maria Vilhena de. op. cit., p. 134.

${ }^{335}$ PONTES DE MIRANDA, Francisco Cavalcanti. op. cit., t. 45, p. 275.

${ }^{336}$ Para os contratos de seguro, álea é a probalibilidade de perda concomitante à probalidade de lucro. FERREIRA, Aurélio Buarque de Holanda. op. cit., p. 95.

${ }^{337}$ VIVANTE, Cesare. Trattato di diritto commerciale: le obbligazioni. 4. ed. Milano: Francesco Vallardi, 1916. v. 4, p. 467.

${ }^{338}$ MARTINS, Fran. Contratos e obrigações comerciais. 15. ed. Rio de Janeiro: Forense, 2001. p. 353.

${ }^{339}$ Obrigação condicional é o vínculo jurídico em que uma pessoa fica adstrita a satisfazer uma prestação em proveito de outra se ocorrer um evento futuro e incerto. GOMES, Orlando. op. cit., p. 9.

${ }^{340}$ MAGALHÃES. José Maria Vilhena de. op. cit., p. 134.
} 
De outro lado, Sergio Cavalieri Filho diz que os três elementos essenciais do seguro são: risco, mutualidade e boa-fé ${ }^{341}$. Logo, o risco sempre é o componente indispensável e significa um acontecimento futuro, incerto e danoso do ponto de vista econômico, para as coisas ou pessoas ${ }^{342}$.

A mutualidade é a submissão de uma mesma comunidade aos mesmos riscos que a leva a contribuir para a formação de um fundo capaz de fazer frente aos prejuízos sofridos pelo grupo. Portanto, a mutualidade é a própria solidariedade e a base econômica do contrato de seguro. Consequentemente, deve existir o equilíbrio econômico entre o risco e o prêmio.

A viabilidade do contrato de seguro depende da estrita boa-fé de ambas as partes e constitui elemento de validade desse negócio jurídico, pois existe disciplinamento expresso da observância desse padrão de comportamento no artigo 765 do Código Civil. Pedro Alvim afirma que a boa-fé é um estado de espírito em harmonia com a manifestação de vontade que vinculou os contratantes, isto é, a intenção pura, isenta de dolo ou de malícia, veiculada com lealdade e sinceridade que não pode induzir a outra parte ao engano ou ao erro ${ }^{343}$.

O artigo 757 do Código Civil dispõe que o seguro é um contrato pelo qual o segurador se obriga, mediante o pagamento de um prêmio, a garantir interesse legítimo do segurado, relativo à pessoa ou à coisa, contra riscos predeterminados ${ }^{344}$. Dessa maneira, o interesse legítimo do segurado é aquele que não contraria a lei, a boa-fé e a moral, sendo de natureza econômica e consubstanciado pela segurança, pela tranquilidade ${ }^{345}$.

Assim, só podem ser seguradas as utilidades que tenham um valor e, por conseguinte, suscetível de risco. Como é cediço, os riscos podem atingir tanto as utilidades propriamente ditas, quanto a faculdade produtora dessas utilidades, que é a vida do homem. O principal elemento da atividade econômica é o trabalho humano, que pode ser entendido como a atividade funcional do sistema muscular e cerebral do homem, que confere à matéria novas utilidades. No homem, sendo ele o agente de produção, reside a faculdade produtora de utilidades ${ }^{346}$.

\footnotetext{
${ }^{341}$ CAVALIERI FILHO, Sérgio. op. cit., p. 437.

${ }^{342}$ Devido à importância desse elemento no contrato de seguro, o risco será tratado no item 4.3.1.2. a seguir.

${ }^{343}$ ALVIM, Pedro. O contrato de seguro. Rio de Janeiro: Forense, 1983. p. 172.

${ }^{344}$ Cavalieri critica o uso da expressão pagamento do prêmio, pois é o segurador quem o recebe e não ele que paga ao segurado. Entretanto, esse autor elogia a parte da definição que diz que o segurador garante o interesse legítimo do segurado e não os seus riscos. CAVALIERI FILHO, Sérgio. op. cit., p. 438.

${ }^{345}$ Id. Ibid., p. 438.

${ }^{346}$ MAGALHÃES. José Maria Vilhena de. op. cit., p. 146.
} 
O seguro, então, tem como objeto compensar esses efeitos econômicos do acaso que destroem as utilidades existentes ou a faculdade produtora das utilidades futuras, de modo que não há espaço para o seguro privado nos eventos que causem necessidades novas ao homem, como o casamento ou nascimento de um filho que, por outro lado, merecem tutela do seguro social. Então, somente para a seguridade social existe a cobertura desse risco "bom”, consoante já tratado no segundo capítulo.

Conforme o Código Civil de 2002, o seguro privado divide-se nas seguintes modalidades: seguro de coisa ou de dano e de pessoa.

\subsubsection{Seguro de dano}

O seguro de coisa também é chamado de seguro de dano e tem por escopo a cobertura dos riscos de um bem que integra o patrimônio do segurado.

Partindo-se do dogma de que não é possível obter vantagem econômica com o seguro, vigora a regra na legislação brasileira de que não se pode segurar uma coisa por mais do que valha nem seu todo mais de uma vez, nos termos do artigo 781 do Código Civil.

Esse seguro de dano pode-se manifestar no de responsabilidade civil, pelo qual o segurador garante o pagamento de perdas e danos devido pelo segurado a terceiros, conforme estabelece o artigo 787 do Código Civil. O beneficiário é o próprio segurado, porque a finalidade é não ter que desembolsar a indenização devida a terceiro ${ }^{347}$.

Todavia, o contraente do seguro pode segurar a responsabilidade própria ou alheia. A responsabilidade própria de que se pode segurar é por ato culposo, ou seja, a atividade dolosa não é segurável. Caso o segurado contrate o seguro de responsabilidade por ato de alguém que ele responde, não existe obstáculo para que celebre contrato de seguro por conduta que outrem realizou dolosamente ${ }^{348}$. Logo, a responsabilidade que se assegura é aquela que não existe dolo do próprio segurado.

$\mathrm{Na}$ verdade, o que se segura é a dívida. O seguro de responsabilidade irá indenizar o que o patrimônio do causador do dano perderá com seu ato ilícito perante o terceiro. Assim, o dano ao patrimônio do responsável é anterior a qualquer ato do terceiro lesado

\footnotetext{
${ }^{347}$ CAVALIERI FILHO, Sérgio. op. cit., p. 447.

${ }^{348}$ PONTES DE MIRANDA, Francisco Cavalcanti. op. cit., t. 46, p. 54.
} 
para obter a indenização, seja pela pretensão exercida, seja pelo direito de ação. Isso significa que não é preciso o exercício do direito de ação nem a pretensão do terceiro atingido para que o segurador preste a indenização ao patrimônio do segurado com a ocorrência do ilícito e o nascimento do dever de indenizar.

O segurado tem o ônus de aviso do sinistro ao segurador, mesmo que esteja segurada a responsabilidade por ato de outrem. Nessa seara, intentada a ação contra o segurado, este dará ciência da lide ao segurador, nos termos do artigo 787, § $4^{\circ}$, do Código Civil. Como é cediço, a ação do terceiro é em face do segurado, que é o devedor. A lei atual permite somente que a indenização seja paga pelo segurador, diretamente, ao terceiro prejudicado nos seguros de responsabilidade obrigatórios ${ }^{349}$.

Feitas essas considerações, infere-se que, apesar de o acidente do trabalho ser um evento que acarreta a responsabilidade sem culpa do empregador pelos danos causados, o seguro que o trabalhador tem direito não é o seguro de responsabilidade civil. Inicialmente, o seguro de responsabilidade civil é para garantir o patrimônio do causador do dano, e não para conferir um direito a outrem em caso de sinistro. Ademais, esse seguro não oferece cobertura para o comportamento doloso do segurado que, no caso, seria o empregador. Dessa forma, o ato intencional que fere a incolumidade físico-psíquica do empregado ficaria sem a proteção.

Portanto, o seguro privado previsto no artigo $7^{\circ}$, inciso XXVIII, da Constituição não é de dano, na modalidade de responsabilidade civil.

\footnotetext{
${ }^{349}$ Além das previsões em leis especiais, o artigo 20 do Decreto-Lei 73/66 lista quais são os seguros obrigatórios, a saber: i) danos pessoais a passageiros de aeronaves comerciais; ii) responsabilidade civil do proprietário de aeronaves e do transportador aéreo; iii) responsabilidade civil do construtor de imóveis em zonas urbanas por danos a pessoas ou coisas; iv) bens dados em garantia de empréstimos ou financiamentos de instituições financeiras pública; v) garantia do cumprimento das obrigações do incorporador e construtor de imóveis; vi) garantia do pagamento a cargo de mutuário da construção civil, inclusive obrigação imobiliária; vii) edifícios divididos em unidades autônomas; viii) incêndio e transporte de bens pertencentes a pessoas jurídicas, situados no País ou nele transportados; ix) revogado pela Lei complementar 126, de 2007; x) crédito à exportação, quando julgado conveniente pelo Conselho Nacional de Seguros Privados, ouvido o Conselho Nacional do Comércio Exterior (CONCEX); xi) danos pessoais causados por veículos automotores de vias terrestres e por embarcações, ou por sua carga, a pessoas transportadas ou não; xii) responsabilidade civil dos transportadores terrestres, marítimos, fluviais e lacustres, por danos à carga transportada. PODER EXECUTIVO. Decreto-Lei 73/66. Disponível em: <http://www.planalto.gov.br/ccivil_03/decreto/1950-1969/d61867.htm>. Acesso em: 26 nov. 2012.
} 


\subsubsection{Seguro de pessoa}

Por outro lado, o seguro de pessoa não está sujeito a uma limitação prévia de indenização. O capital pode ser livremente estipulado pelo proponente que, a seu turno, pode contratar até mais de um seguro sobre o mesmo interesse, com o mesmo ou com diversos seguradores, em respeito ao artigo 789 do Código Civil. O seguro de pessoa subdivide-se em: seguro de vida e seguro de acidente pessoal.

\subsubsection{Seguro de vida}

O seguro de vida é uma espécie de seguro em que o segurador se vincula a prestar capital ou renda periódica a partir de determinado momento, no caso de morte do contraente ou de outrem ou ainda durante a sua vida, desde que receba o prêmio ${ }^{350}$. Por seu turno, esse seguro, ainda, classifica-se em seguro por morte ou por sobrevivência para o caso de vida. Naquele, o sinistro é a morte do segurado ou de terceiro, ao passo que neste, o evento é sobreviver o segurado ou o terceiro a determinado dia ou dia determinável.

Cumpre registrar que José Maria Vilhena Barbosa de Magalhães considerou, no início do século XX, em Portugal, o seguro de acidentes do trabalho como seguro de pessoa na modalidade de seguro de vida em caso de sobrevivência, pois o infortúnio trabalhista pode ocasionar também invalidez. O patrão segura os seus empregados ou a ele próprio dos riscos provenientes de acidentes do trabalho que seus obreiros possam sofrer, por cujas indenizações seja responsável. O contrato é feito no próprio nome do empregador, pois ele é o efetivamente segurado e a vida dos empregados é o objeto do seguro. Os direitos da indenização dos empregados nascem da lei, e não do contrato propriamente dito ${ }^{351}$.

Entretanto, essa posição não pode ser defendida pelos conceitos atuais. Esse contrato de seguro feito em nome do próprio empregador para proteger o seu patrimônio de eventual sinistro ocorrido com o empregado no curso do contrato de trabalho é um seguro de responsabilidade civil, conforme já mencionado. Esse autor português propugnou um seguro para o empregador, e não para o empregado, como prevê a Constituição Federal de 1988.

Sabe-se que a morte ou a invalidez sofrida pelo trabalhador em razão do seu labor são as consequências negativas do acidente do trabalho e, por isso, o seguro deveria

\footnotetext{
${ }^{350}$ PONTES DE MIRANDA, Francisco Cavalcanti. op. cit., t. 46, p. 3.

${ }^{351}$ MAGALHÃES. José Maria Vilhena de. op. cit., p. 193.
} 
garantir a incolumidade psíquica e física no curso da relação de emprego. Então, para melhor justificar a impertinência do seguro de vida para a modalidade proposta, convém trazer elementos do seguro de acidente pessoal, que será agora detalhado.

\subsubsection{Seguro de acidente pessoal, uma proteção ao trabalhador}

O seguro de acidente pessoal é o negócio jurídico pelo qual o segurador tem a prestação de garantir a incolumidade física e psíquica em caso de acidente pessoal do segurado e indenizá-lo, diretamente ou por seus beneficiários, caso o evento se materialize, mediante o recebimento de um prêmio. Sabe-se que o infortúnio pessoal pode resultar em lesão corporal ou psíquica, temporária ou permanente, e até a morte. Dessa forma, a morte é uma das possíveis consequências de acidente pessoal e, por conseguinte, é permitido inserir no contrato de seguro de acidente pessoal uma cláusula de prestação em caso de morte. Isso não transmuda a natureza desse contrato para seguro de vida.

Como é cediço, o acidente do trabalho é uma modalidade de acidente pessoal. No curso da relação de emprego, o acidente do trabalho desencadeia diversos danos para o empregado e também para sua família, pois em caso de morte ou redução da capacidade laborativa, seus entes queridos continuam com necessidades a serem supridas, mas a fonte de produção dessas utilidades extingue-se. Para minorar esses efeitos, juntamente com o seguro social, a Constituição Federal determina que o empregador é obrigado a segurar os seus empregados dos riscos provenientes de acidentes do trabalho que eles venham a sofrer em razão da atividade exercida (artigo $7^{\circ}$, inciso XXVIII).

Isso é possível, pois os figurantes do contrato de seguro são, pelo menos, dois: segurado e segurador. Todavia, existem casos em que o seguro seja feito em favor de outrem, que será o segurado sem ser o contratante. Nesse caso, o contratante vinculou-se a adimplir todos os deveres e as obrigações derivados do contrato, salvo aqueles que só o terceiro poderia fazer. E, por fim, o seguro pode ser a favor de quem for o interessado, isto é, durante a vigência do contrato poderá variar a pessoa que está em relação ao objeto. A relação jurídica entre o contraente e o terceiro, dito segurado, decorre de outro negócio jurídico ou de situação fática entre eles ${ }^{352}$.

\footnotetext{
${ }^{352}$ PONTES DE MIRANDA, Francisco Cavalcanti. op. cit., t. 45, p. 275-277.
} 
No caso em comento, o empregador possui uma relação jurídica de emprego com o empregado devido ao contrato de trabalho. Essa relação jurídica confere ao empregado um direito subjetivo de exigir do empregador um seguro contra acidentes do trabalho, por força do artigo $7^{\circ}$, inciso XXVIII da Constituição Federal. O empregador, por seu turno, tem o dever de contrair esse seguro em favor de quem for o interessado, ou seja, em favor de quem for seu empregado até um determinado lapso temporal após a cessação da relação de emprego, pois muitas enfermidades ocupacionais manifestam-se em ocasião ulterior.

A peculiaridade de algumas doenças ocupacionais que se manifestarem em momento posterior ao término da relação de emprego não afasta a responsabilidade da seguradora por essas indenizações, pois se trata de cobertura de um risco futuro que já foi analisado em seus cálculos matemáticos para o prêmio. Essa prestação da seguradora é uma das obrigações do contrato que pode ser exigida após o término do vínculo empregatício. Assim, o início da validade do contrato de seguro é simultâneo ao começo do contrato de trabalho. Contudo, o fim de sua validade não deve coincidir com o término da relação de emprego e, sim ser considerado um lapso temporal posterior ao fim do contrato de trabalho, que seja suficiente para que as doenças ocupacionais daquele ramo específico de atividade restem configuradas.

Entretanto, resta a possibilidade de que essas doenças ocupacionais apresentem seus sintomas e sejam detectadas após o término de vigência do contrato de seguro e, consequentemente, esses empregados doentes não terão seu recebimento garantido pelo segurador. Todavia, entende-se que o empregador permanece com o dever de indenizar os danos materiais e os morais decorrentes da doença ocupacional pelo marco temporal estabelecido no Código Civil para a prescrição da pretensão de reparação civil ${ }^{353}$, contados a partir da ciência inequívoca da incapacidade laboral ${ }^{354}$.

Consigna-se o posicionamento diverso, exposto por Alexandre Agra Belmonte, que considera o prazo prescricional de 5 anos, limitados aos 2 últimos anos, contados a

\footnotetext{
${ }^{353} \mathrm{O}$ Código Civil de 2002 reduziu o prazo prescricional para 3 anos referente à prescrição da pretensão de reparação civil (artigo 206, § 3º, V). Sobre as regras prescricionais de transição entre os Códigos de 1916 e 2002, reporta-se aos comentários já tecidos no capítulo 2, item 2.2.3.2. supra.

${ }^{354}$ Súmula 230 do Supremo Tribunal Federal: "A prescrição da ação de acidente do trabalho conta-se do exame pericial que comprovar a enfermidade ou verificar a natureza da incapacidade". SUPREMO TRIBUNAL FEDERAL. Súmula 230. Disponível em: $<$ http://www.dji.com.br/normas_inferiores/regimento_interno_e_sumula_stf/stf_0230.htm>. Acesso em: 24 nov. 2012. Súmula 278 do Superior Tribunal de Justiça: "O termo inicial do prazo prescricional, na ação de indenização, é a data em que o segurado teve ciência inequívoca da incapacidade laboral. SUPERIOR TRIBUNAL DE JUSTIÇA. Súmula 278. Disponível em: $<$ http://www.dji.com.br/normas_inferiores/regimento_interno_e_sumula_stj/stj_0278.htm>. Acesso em: 24 nov. 2012.
} 
partir da manifestação dos efeitos das doenças, sob o argumento de que são créditos trabalhistas os danos patrimoniais e morais decorrentes do acidente do trabalho ${ }^{355}$. Outrossim, cumpre registrar, que Jorge Luiz Souto Maior aduz que a ação para postular a indenização dos danos decorrentes de acidentes do trabalho é imprescritível, pois atingem a personalidade humana, em um contexto da dinâmica das relações hierarquizadas do modo de produção capitalista ${ }^{356}$.

Portanto, o empregado é o segurado e o empregador é o contratante que assume todos os deveres desse contrato de seguro, precipuamente, o pagamento do prêmio. $\mathrm{O}$ empregador é o tomador de seguro e tem interesse na cobertura desse risco, pois o acidente do trabalho pode ocasionar uma perda do seu patrimônio, em virtude das indenizações a que está sujeito. Mas, esse seguro é para o empregado, e não para proteger seu patrimônio.

Esse seguro pode ser contratado pelo empregador na modalidade coletiva, ou seja, o seguro cobre todos os riscos de uma pluralidade de pessoas que estejam mencionadas na apólice $^{357}$. Todos os empregados devem ser segurados.

Na hipótese de ocorrer o acidente do trabalho, o segurador é obrigado a prestar o que foi determinado na apólice contra os efeitos desse evento danoso. O beneficiário desse seguro poderá ser o próprio empregado segurado ou seus familiares ou, ainda, aqueles que provarem sua privação dos meios necessários à subsistência com o acidente do trabalho sofrido pelo trabalhador. Assim, os beneficiários desse seguro devem ser restritos às pessoas mencionadas no artigo 792 da lei civil, haja vista que subjacente a esse contrato, está o caráter protetivo ao empregado que teve sua força de trabalho afetada por eventual acidente. O intuito é ampará-lo, bem como aquelas pessoas próximas que tiveram suas providências reduzidas por essa incapacidade dele. Caso contrário, estender esse seguro a pessoas diversas seria desvirtuar a natureza do instituto.

Dentro desse contexto, é imperioso apontar a ilegalidade e, por via reflexa, também a inconstitucionalidade do artigo $5^{\circ}$, inciso I, alíneas b), b.1) e b.3), da Resolução do Conselho Nacional de Seguros Privados (CNSP) no 117, de 22 de dezembro de 2004, que estabelece os critérios das coberturas de risco oferecidas em plano de seguro de

\footnotetext{
${ }^{355}$ BELMONTE, Alexandre Agra. Curso de responsabilidade trabalhista: danos morais e patrimoniais nas relações de trabalho. 2. ed. São Paulo: LTr, 2009. p. 300.

${ }^{356}$ SOUTO MAIOR, Jorge Luiz. A prescrição do direito de ação para pleitear indenização por dano moral e material decorrente de acidente do trabalho. Revista LTr, São Paulo. v. 70, n. 5, p. 541, maio. 2006.

${ }^{357}$ Apólice é o instrumento de constituição do contrato de seguro que deverá consignar: os riscos assumidos, o valor do objeto e o prêmio devido pelo segurado ou pelo estipulante. GOMES, Orlando. Contratos. 21. ed. Rio de Janeiro: Forense, 2000. p. 413.
} 
pessoas. Esse ato infralegal considera acidente pessoal o evento com data caracterizada, exclusivo e diretamente externo, súbito, involuntário e violento, e causador de lesão física que, por si só e independentemente de qualquer outra causa, tenha como efeito direto a morte ou invalidez total ou parcial, temporária ou permanente, do segurado ou que torne necessário o tratamento médico. Em seguida, esse diploma exclui do conceito as doenças profissionais e as decorrentes, dependentes, predispostas ou facilitadas pelos esforços repetitivos, tais como a lesão por esforços repetitivos (LER), as doenças osteomusculares relacionadas ao trabalho $(\mathrm{DORT})^{358}$.

A resolução é o ato administrativo de caráter normativo, editado por autoridades de alto escalão ou por dirigentes de órgão colegiado com a finalidade de estabelecer normas sobre a matéria de competência do órgão, mas que não pode contrariar a Constituição, a lei, o decreto regulamentar ${ }^{359}$.

Dessa forma, as doenças ocupacionais são consideradas, pelo artigo 20 da Lei 8.213/91, acidentes do trabalho por equiparação. Essas doenças são infortúnios que desencadeiam o recebimento dos benefícios previdenciários. Portanto, uma resolução editada pelo Conselho Nacional de Seguros Privados não pode ultrapassar os limites da própria lei que define acidente do trabalho e, ademais, não é apta para criar restrições à cobertura dessas doenças desencadeadas em razão dos riscos da atividade econômica a que estão expostos os empregados.

De modo indireto, esse ato administrativo fere a Constituição Federal, no artigo $7^{\circ}$, inciso XXVIII, ao limitar o direito do trabalhador ao seguro contra acidentes do trabalho em razão dos riscos a que está exposto pelo seu labor.

Assim, essa resolução, eivada de ilegalidade e de inconstitucionalidade, não irradia seus efeitos no mundo jurídico e, consequentemente, não interfere na implementação do seguro privado como um direito constitucional do trabalhador para caso do acidente do trabalho oriundo dos riscos da atividade do empregador.

\footnotetext{
${ }^{358}$ SUPERINTENDÊNCIA DE SEGUROS PRIVADOS - SUSEP. Conselho Nacional de Seguros Privados CNSP. Resolução $\mathrm{n}^{\circ}$ 117, de 22 de dezembro de 2004. Disponível em: $<$ http://www.susep.gov.br/menubiblioteca/seguro_pessoas_606>. Acesso em: 10 jun. 2012.

${ }^{359}$ MEDAUAR, Odete. Direito administrativo moderno. 5. ed. São Paulo: Ed. Revista dos Tribunais, 2001. p. 171.
} 


\subsection{Mecanismos de integração da culpa e do risco}

As normas jurídicas referentes à organização do segurador e ao direito de ação do empregado e da seguradora de se obter um provimento judicial condenatório de o empregador lhes pagar uma quantia em dinheiro são apresentadas como mecanismos estáticos e dinâmicos para a integração da culpa e do risco na responsabilidade civil dos acidentes do trabalho.

Os mecanismos estáticos são aqueles que se referem às exigências de formação das seguradoras, que devem variar de acordo com os riscos que os trabalhadores estiverem expostos, pois é o montante de capital investido que conferirá a segurança de indenização às vítimas.

Por outro lado, os mecanismos dinâmicos são aqueles conferidos às seguradoras e aos empregados para postularem a condenação do empregador se incorrer em dolo ou em culpa.

\subsubsection{Mecanismos estáticos}

As seguradoras necessitam ser instituídas como sociedades anônimas ou cooperativas, a fim de serem capazes de indenizar os prejuízos sofridos pelos empregados segurados se ocorrer o infortúnio trabalhista. Além disso, a participação do Poder Público é fundamental diante de riscos extraordinários que se verificam na atualidade.

\subsubsection{A natureza jurídica das seguradoras}

De acordo com Cesare Vivante, para se alcançar o equilíbrio industrial entre o prêmio e o capital assegurado, a seguradora precisa estender os negócios sobre uma vasto território e por uma série de anos, bem como ganhar a confiança dos segurados com um capital inicial de garantia. Esses requisitos exigem exceder a força e a vida de um indivíduo e, assim, qualquer perigo de morte ou abuso do segurador removem a fé sobre a 
solvabilidade da empresa que, por sua vez, é indispensável para o comércio $^{360}$. Consequentemente, uma empresa individual $^{361}$, em nome coletivo ${ }^{362}$ ou em comandita simples $^{363}$, está longe da realidade do contrato de seguro e, por isso, nenhuma lei preocupou-se de regular.

A Constituição Federal de 1988 impõe ao empregador o dever de contratar um seguro privado.

Logo, a efetivação desse negócio jurídico confere ao empregador a liberdade de contratar as empresas de seguro privado que, por sua vez, podem se organizar, no Brasil, somente como sociedades anônimas ${ }^{364}$ ou cooperativas ${ }^{365}$, nos termos do artigo 24 do Decreto 73/66. A preocupação sempre reside na solvabilidade da seguradora.

O balanço anual das seguradoras deve ter um resíduo dos prêmios coletados antecipadamente para os riscos futuros, constituindo, esse fundo, uma garantia para os segurados. Esse fundo é denominado de "reserva pelo risco em curso" e apresenta uma função tanto retrospectiva quanto prospectiva. Do ponto de vista pretérito, refere-se ao modo como se forma, ou seja, uma quantidade de prêmios coletados, que são aumentados pelos interesses envolvidos, e que não foi utilizada para pagar os sinistros já liquidados. Na função futura, essa reserva é o montante de prêmios coletados, aumentados pelos interesses em tela, e que é necessária para pagar os sinistros futuros não cobertos pelos prêmios

\footnotetext{
${ }^{360}$ VIVANTE, Cesare. op. cit., v. 4, p. 468-469.

${ }^{361}$ Empresa individual é a atividade econômica organizada profissionalmente por um único indivíduo com o fim de produção e circulação de bens e serviços. A lei civil brasileira, no artigo 980-A, inserido pela Lei 12441/2011, permitiu que a empresa individual seja constituída sob responsabilidade limitada ao valor do capital social integralizado, ou seja, uma empresa formada por uma única pessoa titular da totalidade do capital social, devidamente integralizado, que não será inferior a 100 (cem) vezes o maior salário-mínimo vigente no país.

${ }^{362}$ A sociedade em nome coletivo é uma sociedade de pessoas, na qual predomina o caráter intuitu personae, tendo como principal característica a responsabilidade solidária e ilimitada de todos os sócios, nos termos do artigo 1039 do Código Civil. BULGARELLI, Waldirio. Sociedades comerciais: sociedades civis e sociedades cooperativas; empresas e estabelecimento commercial. 9. ed. São Paulo: Atlas, 2000. p. 45.

${ }^{363}$ A sociedade em comandita simples é aquela que possui duas categorias de sócios, a saber: os comanditados, pessoas físicas que respondem solidária e ilimitadamente, e os comanditários, obrigados somente pelo valor de sua cota, consoante o artigo 1045 do Código Civil. BULGARELLI, Waldirio.op. cit., p. 82.

${ }^{364}$ Sociedade anônima é aquela de natureza mercantil em que o capital se divide em ações de livre negociabilidade, limitando-se a responsabilidade dos subscritores ou acionistas ao preço de emissão das ações por eles subscritas ou adquiridas. CARVALHOSA, Modesto. Comentários à Lei de Sociedades Anônimas. 3. ed. São Paulo: Saraiva, 2000. v. 1, p. 4.

${ }^{365} \mathrm{~A}$ sociedade cooperativa é aquela em que as pessoas reciprocamente se obrigam a contribuir com bens ou serviços para o exercício de uma atividade econômica, de proveito comum, sem objetivo de lucro, nos termos do artigo 3o da Lei 5.764/71. As cooperativas são sociedades sui generis, pois ficam a meio caminho entre a sociedade civil e a empresária. VERÇOSA, Haroldo Malheiros Duclerc. Curso de direito comercial 2: teoria geral das sociedades; as sociedades em espécie do Código Civil. São Paulo: Malheiros Ed., 2006. p. 456.
} 
futuros. A formação dessa massa revela a responsabilidade dos administradores em constituí-la e mantê-la íntegra ao fim de cada exercício ${ }^{366}$.

No mercado brasileiro, o Conselho Nacional de Seguros Privados (CNSP) tem atribuição para estipular índices e demais condições técnicas sobre tarifas, investimentos e outras relações patrimoniais a serem observadas pelas sociedades seguradoras, consoante o artigo 32, inciso III, do Decreto 73/66.

Para garantia de suas obrigações, as sociedades seguradoras constituirão reservas técnicas, fundos especiais e provisões, em conformidade com os critérios fixados pelo CNSP, além das reservas e fundos determinados em leis especiais, nos termos do artigo 84 do Decreto 73/66. No contexto de garantir o recebimento, o artigo 86 desse diploma normativo prevê que, se uma sociedade seguradora ingressar em um procedimento de liquidação extrajudicial por algum dos motivos previstos lei, será conferido ao segurado ou beneficiário um privilégio especial sobre as reservas técnicas, fundos especiais e provisões para o fim de receber a indenização.

Então, no caso de não receber a indenização da seguradora, o empregado terá o direito de agir diretamente em face do empregador que lhe causou o acidente do trabalho e pleitear o pagamento de todos os danos sofridos, com fundamento na responsabilidade objetiva.

Não obstante todo o aparato legal conferido às seguradoras para garantir a solvabilidade das reparações às vítimas, existem riscos extraordinários que comprometem essa segurança. Como antídoto a esses perigos contemporâneos, tem-se o cosseguro entre o setor público e o privado.

\subsubsection{Cosseguro entre o setor privado e o setor público para os riscos extraordinários}

Risco é um acontecimento futuro e incerto, danoso para as coisas ou para as pessoas. Esses danos devem ser econômicos. A exigência de ser um evento vindouro, traz a seguinte regra: se o segurador souber que o risco já ocorreu no momento da contratação

${ }^{366}$ VIVANTE, Cesare. op. cit., v. 4, p. 470. 
e, ainda assim, finalizar o contrato, ele deverá pagar em dobro o prêmio estipulado, nos termos do artigo 773 do Código Civil.

O risco tem dois fatores: um subjetivo e outro objetivo. Risco objetivo são os fatos e as situações da vida real que, dentro dos cálculos da probabilidade, causam dano. Diversamente, risco subjetivo é aquele que se relaciona com as características pessoais de cada um, ou seja, com o perfil do segurado ${ }^{367}$.

Impõe registrar que, para Pedro Alvim, risco é o acontecimento possível, futuro e incerto ou de data incerta que não depende da vontade das partes e que não precisa ser necessariamente danoso ${ }^{368}$. No escólio desse autor, o seguro nada mais é que a transferência do risco do segurado para o segurador, isto é, as consequências danosas desse risco $^{369}$. Assim, apesar de ele negar a característica danosa ao definir risco, afirma-a, em momento seguinte, ao explicar qual é a finalidade do contrato de seguro. Por isso, entende-se que o risco, para o contrato de seguro, tem a potencialidade de causar dano, isto é, prejuízo.

O risco também pode ser definido, ainda, como um acontecimento eventual proveniente de causa que independe exclusivamente da vontade humana. A eventualidade caracteriza-se por dois elementos, a saber: um interno, de ordem objetiva, que é a inevitabilidade ou a impossibilidade de impedir ou de resistir ao acontecimento objetivamente considerado; e outro externo, de ordem subjetiva, que é a ausência de dolo. Como corolário, tem-se que o seguro não produz seus efeitos se o sinistro foi determinado por ato voluntário e intencional do próprio segurado.

No decorrer do contrato de seguro, os riscos existentes podem ser agravados por causas supervenientes. Essa exacerbação pode afetar o equilíbrio econômico do contrato e, por isso, o prêmio e a indenização precisam ser revistos. Ressalva-se que, se o risco foi intencionalmente ampliado pelo segurado, ele perderá o direito à garantia, de acordo com o artigo 768 do Código Civil. Logo, somente a atitude dolosa do segurado afasta a indenização.

Todavia, o risco também pode ser ampliado sem dolo e sem culpa ou até com culpa do segurado. Nessas hipóteses, ele deve avisar o segurador tão logo que saiba dessa ampliação, sob pena de perder o direito à garantia, se for provado que silenciou de má-fé, segundo o artigo 769 do Código Civil. O prêmio não poderá ser aumentado, mas o segurador

\footnotetext{
${ }^{367}$ CAVALIERI FILHO, Sérgio. op. cit., p. 439.

${ }^{368}$ ALVIM, Pedro. op. cit., p. 215.

${ }^{369}$ Id. Ibid., p. 229.
} 
poderá resolver o contrato nos 15 (quinze) dias subsequentes ao recebimento do aviso de agravamento do risco sem culpa do segurado. Contudo, a eficácia dessa resolução operar-se-á nos 30 (trinta) dias após a notificação, devendo ser restituída a diferença do prêmio.

Por outro lado, ainda é possível que o risco diminua consideravelmente e, por conseguinte, o segurado poderá exigir a revisão do prêmio ou a resolução do contrato, nos termos do artigo 770 do Código Civil.

O risco coberto na apólice de seguro será o acidente do trabalho, isto é, o evento, súbito ou paulatino, que causa danos à saúde do trabalhador e que seja proveniente do exercício da atividade profissional. Embora o caso fortuito e a força maior sejam, normalmente, incluídos nas coberturas de seguro, nos acidentes do trabalho, será necessário verificar se esses acontecimentos provocaram ou não o rompimento do nexo causal e, consequentemente, afetaram ou não a configuração do acidente do trabalho propriamente dito ${ }^{370}$. Na verdade, se houver o rompimento do nexo causal, não haverá o acidente do trabalho e não incidirão as regras securitárias.

O fato exclusivo do segurado é também motivo que enseja o a interrupção do nexo causal entre o fato e os danos decorrentes, e não haverá a qualificação do acidente do trabalho. O artigo 762 do Código Civil reforça que o contrato garantidor de risco proveniente de ato doloso do segurado, do beneficiário ou de representante de um ou de outro será nulo, pois, caso contrário, ao conferir segurança para atos dolosos, estimular-seia a criminalidade e eliminar-se-ia o próprio risco, que é marcado pela incerteza ${ }^{371}$. Até a cobertura acidentária do INSS exclui o pagamento do benefício para o segurado que agiu dolosamente.

Apesar de o empregador ser o estipulante do contrato de seguro e não o segurado ou o segurador, ele não é considerado terceiro para o fim de rompimento do nexo causal do acidente do trabalho. Conforme já analisado, o fato de terceiro eficiente para quebrar o nexo causal é ilícito se praticado por alguém que não seja o acidentado, o empregador ou os seus prepostos. Assim, se o acidente for causado pelo empregador será garantido pelo seguro privado.

\footnotetext{
${ }^{370}$ No tocante às causas excludentes do nexo causal que impedem a caracterização do fato como acidente do trabalho, alude-se ao capítulo 3, item 3.3. supra.

${ }^{371}$ CAVALIERI FILHO, Sérgio. op. cit., p. 457-458.
} 
Os riscos de acidentes do trabalho estão diretamente relacionados com os da atividade econômica exercida e, consequentemente, as atividades mais perigosas apresentam maior risco de infortúnio.

Nesse sentido, os riscos das atividades econômicas desempenhadas pelo empregador podem ser divididos em ordinários e extraordinários. Os ordinários são os que apresentam um comportamento estatístico regular, com uma modificação escalonada dentro de limites que permitem calcular os coeficientes necessários à organização da técnica do seguro. Em contrapartida, os riscos extraordinários são aqueles que reclamam um tratamento especial do segurador para a cobertura, uma vez que suas causas e efeitos são incontroláveis e imprevisíveis, o que, por seu turno, reduzem ou anulam as possibilidades técnicas de estabilização por meio dos dados estatísticos ${ }^{372}$.

Os riscos extraordinários desencadeiam danos sistematicamente definidos, por vezes irreversíveis, que podem permanecer invisíveis por um longo período. A definição desses riscos deve passar por processos sociais ${ }^{373}$, uma vez que as suas constatações baseiam-se em interesses sociais, mesmo quando se revestem de certeza técnica. Em razão dos diversos atores sociais envolvidos com seus valores diversos, há um conflito plural de riscos civilizacionais observável. Cada grupo arma-se com definições de risco com o escopo de afastar aqueles que lhes trazem prejuízos financeiros ${ }^{374}$. Como corolário, aumenta a importância social e política do conhecimento, bem como do acesso dos meios de obtê-lo e sua divulgação. Nas situações de risco, o conhecimento determina o ser.

Por essas razões, a solução para esses riscos passa por uma decisão política, haja vista que a sociedade contemporânea tem uma dinâmica evolutiva democrática e sua congregação está na solidariedade de esforços diante da autoameaça civilizacional.

Os riscos proliferam nas diversas descobertas técnicas e científicas, tais como: nos organismos geneticamente modificáveis e nas ondas eletromagnéticas nos celulares, por exemplo. A ignorância quanto às consequências exatas a curto e a longo prazo de determinadas ações não pode servir de pretexto para deixar para mais tarde a adoção de medidas que visem prevenir a degradação ambiental, isto é, diante da incerteza ou

\footnotetext{
${ }^{372}$ ALVIM, Pedro. op. cit., p. 253.

${ }^{373}$ BECK, Ulrich. Sociedade de risco: rumo a uma outra modernidade. Trad. Sebastião Nascimento. São Paulo: Ed. 34, 2010. p. 27.

${ }^{374}$ Id. Ibid., p. 36.
} 
controvérsia científica atual, é melhor tomar as providências de proteção severas a título de precaução do que nada fazer ${ }^{375}$.

Os efeitos colaterais desse novo modo de produção podem ser sociais, econômicos e políticos, e sempre existe o potencial político das catástrofes. Por isso, a esfera pública e política passam a reger o gerenciamento empresarial. A prevenção e o manejo envolvem uma reorganização do poder e da responsabilidade ${ }^{376}$.

Então, é imperioso que a prestação de garantia do contrato de seguro contra esses riscos extraordinários seja feita por mais de um segurador para efetivar todo o impacto dessa indenização, pois a seguradora tem liberdade de conceber os planos técnicos do seguro de acordo com a conveniência e a viabilidade do próprio negócio, sob pena de não ter a estabilidade necessária à indenização.

Isso porque a apólice ou bilhete de seguros poderá mencionar os riscos assumidos e, consequentemente, ter cláusulas limitativas deles por força de norma insculpida no artigo 760 do Código Civil. O segurador privado pode restringir a cobertura de determinados riscos devido a sua gravidade e sua extensão, tendo-se em vista o equilíbrio da mutualidade ${ }^{377}$.

Os riscos extraordinários existentes na atualidade promovem uma nova organização social. A sociedade de riscos é aquela conscientizada de que as fontes de riqueza estão contaminadas por ameaças colaterais que, por sua vez, disseminam-nos. Essa sociedade opõe-se à sociedade da escassez, que é aquela cujo fundamento da produção é o combate da miséria isolada e gritante, pois a utilização econômica da natureza liberta as pessoas das sujeições tradicionais. Essa preocupação com a subsistência material cedeu espaço para promessa de segurança com os riscos e os potenciais de ameaça que são desencadeados pelas forças produtivas e tecnológicas ${ }^{378}$.

Por outro lado, o Estado tem interesse na continuidade das atividades econômicas para o progresso social, bem como tem por finalidade precípua o bem-estar social da coletividade $^{379}$. O objetivo da participação do Poder Público nos seguros de acidentes do trabalho é apenas reforçar a garantia da indenização nos empreendimentos de riscos

\footnotetext{
${ }^{375}$ PRIEUR, Michel. op. cit., p. 154.

${ }^{376}$ BECK, Ulrich. op. cit., p. 27-28.

${ }^{377}$ A cláusula limitativa do risco não se confunde com a cláusula abusiva, pois enquanto a aquela restringe a obrigação assumida pelo segurador, esta restringe ou exclui a responsabilidade decorrente de uma obrigação regularmente assumida pelo segurador ou visa até a obter um proveito sem causa.

${ }^{378}$ BECK, Ulrich. op. cit., p. 23-25.

${ }^{379}$ SILVA, Wilson Melo da. op. cit., p. 174.
} 
extraordinários, e não de substituir a iniciativa privada. Não se pode olvidar que o artigo 173 da Constituição Federal prescreve que a exploração direta de atividade econômica pelo Estado só será permitida quando necessária aos imperativos da segurança nacional ou a relevante interesse coletivo, conforme definidos em lei.

O ente federado responsável por essa participação é a União, pois além dessas atividades interessarem ao desenvolvimento do país, a ela compete explorar os serviços e instalações nucleares de qualquer natureza, nos termos do artigo 21, inciso XXIII, da Constituição. $\mathrm{Na}$ atualidade, a atividade nuclear é ícone de riscos extraordinários e sua responsabilidade é sempre objetiva.

No intuito de equilibrar o desenvolvimento de atividades necessárias e os riscos extraordinários decorrentes, deve existir um cosseguro entre a seguradora privada e o setor público, a fim de distribuir os ônus dos riscos entre esses seguradores, ainda que seja um seguro de acidente do trabalho. No cosseguro, a obrigação é divisível e a apólice indicará o segurador que administrará o contrato e representará os demais para todos os efeitos, em consonância com o artigo 761 do Código Civil. No cosseguro não existe solidariedade dos seguradores, cada um só assume a sua cota de risco ${ }^{380}$.

É de se pontuar que esse cosseguro não se confunde com o seguro conjunto e cumulativo, que também é contratado por vários seguradores. Todavia, nessa modalidade, os seguradores assumem a responsabilidade sobre o conjunto do risco sem determinação das partes. Essa figura não pode ser adotada para o seguro de acidentes do trabalho, em razão da possibilidade de todos os ônus recaírem somente para o Estado e as seguradoras privadas não arcarem com as indenizações.

\subsubsection{Limites da reparação dos danos pela seguradora}

A indenização dos danos decorrentes do acidente do trabalho é a obrigação condicional do segurador em caso de sinistro. Essa responsabilidade pode ser limitada a importância do prêmio pago e este varia de acordo com o risco coberto.

${ }^{380}$ PONTES DE MIRANDA, Francisco Cavalcanti. op. cit., t. 45, p. 292. 
O valor segurável a título de dano material será calculado com base na força de trabalho do obreiro acidentado, que estará morto ou enfermo, haja vista que a vida é considerada como uma faculdade produtora de utilidades.

No tocante ao dano moral, que é uma das espécies de dano pessoal, existirá também a previsão de uma cobertura securitária para o caráter recompensador da vítima, com base na extensão do dano. Todavia, o dano moral pode apresentar uma faceta punitiva, a qual se mede com a capacidade econômica do agente. Essa vertente do dano moral não pode ser reembolsada pela seguradora, uma vez que o seguro não pode ter o caráter de pena. Caso contrário, ficaria desnaturada essa face sancionatória do dano moral $^{381}$.

Então, o prêmio deverá ser estipulado em um valor que corresponda à indenização por danos materiais e morais provenientes do acidente do trabalho, sempre com a característica de reparabilidade.

Essa interpretação do inciso XXVIII do artigo $7^{\circ}$ da Constituição traz a vantagem de solvabilidade do dano material e do moral até o limite da reparabilidade.

Caso o empregado cogite um valor superior, a título de dano material ou moral, poderá ingressar com demanda na própria Justiça do Trabalho, com base no artigo 114, inciso VI, da Constituição, sob o fundamento da responsabilidade objetiva pelo risco profissional na atividade que exercia até o momento do sinistro e postular um montante superior, já excluídos os prejuízos material e o moral cobertos pelo seguro. O segurado que recebeu sua indenização pelos danos sofridos decorrentes do acidente do trabalho não tem interesse de agir para postular em face do empregador a mesma indenização, consoante o artigo $3^{\circ}$ do Código de Processo Civil.

Já estabelecidos os padrões de tutela para a indenização do empregado pelos danos sofridos em razão do acidente do trabalho, resta saber como a ordem jurídica equilibra o outro lado da relação jurídica e impõe ao empregador o cumprimento das obrigações de saúde e de segurança do trabalho, com o objetivo de evitar esses sinistros.

\footnotetext{
${ }^{381}$ GURGEL FILHO, Milton; FERNANDES, Marcus Frederico B. Dano moral e o seguro de responsabilidade civil. Revista do Advogado, Sao Paulo, n. 47, p. 32, mar. 1996.
} 


\subsubsection{Mecanismos dinâmicos}

A indenização prevista no contrato de seguro de acidente do trabalho, estipulado pelo empregador em favor do empregado, para os danos sofridos em caso de sinistro, é sempre devida se os danos são provenientes do infortúnio, já que a responsabilidade do empregador é objetiva e decorre do risco profissional.

Entrementes, esse seguro é um direito para o empregado, pois sua indenização estará sempre garantida por uma seguradora ou, em algumas atividades, também pelo Poder Público representado pela União. Assim, ocorrido o ato ilícito, nasce para o empregado a pretensão ao ressarcimento e à reparabilidade dos danos, que será a cargo da seguradora ou desta, juntamente com União e, consequentemente, o trabalhador não estará sujeito a eventual insolvência de seu empregador.

Assim, com a emissão do comunicado de acidente do trabalho (CAT) ou outro documento hábil a provar o acidente (atestado médico, por exemplo), o empregado terá o direito ao seguro. E se, por ventura, a seguradora negar-se ao adimplemento de sua prestação contratual?

\subsubsection{Exercício do direito de ação e a legitimidade ad causam}

Está-se diante, então, de uma lide entre empregado ${ }^{382}$ (segurado) e seguradora que deverá ser instaurada na Justiça do Trabalho, com fulcro no artigo 114, inciso I, da Constituição Federal, pois a relação entre a seguradora e o empregado (segurado) será decorrente da relação de trabalho que previu esse contrato de seguro como um direito constitucional do empregado e fundado no próprio risco da atividade a que está submetido durante o seu labor.

Em razão do negócio jurídico de seguro, o empregador transfere o adimplemento dessa indenização acidentária para a seguradora, isoladamente, ou em conjunto com a União. Como efeito, a devedora principal é a própria seguradora, e não o empregador.

\footnotetext{
${ }^{382}$ Deve-se observar que em caso de óbito do empregado, em razão do acidente do trabalho, seus familiares ou as pessoas por ele indicadas serão os beneficiários que receberão o montante indenizatório e, por conseguinte, terão legitimidade para pleiteá-lo.
} 
Entretanto, o empregado poderá pleitear uma indenização por danos morais e materiais que ultrapasse o valor segurável em face somente do empregador, sob o fundamento do risco da atividade, consoante já explorado no item 4.3.1.3. supra. A dívida do empregador é complementar ao montante pago pela seguradora, que é a devedora principal e, por isso, o pedido de indenização em face do empregador e da seguradora será em valores diferentes.

Além disso, em caso de insolvência da seguradora, o empregador responderá subsidiariamente pelos danos decorrentes do acidente do trabalho, pois sua responsabilidade é fundada no risco de sua atividade.

Assim, o empregador terá uma obrigação de complementar, no tocante à indenização pelos danos morais e materiais sofridos pelo empregado, bem como terá o dever subsidiário pelas obrigações da seguradora em caso de inadimplência.

Em razão desse dúplice dever do empregador, eventual demanda proposta pelo empregado será direcionada tanto à seguradora, isoladamente ou em conjunto com a União, quanto ao empregador. Então, haverá um litisconsórcio passivo necessário ${ }^{383}$, sob o argumento de que, pela natureza da relação jurídica, o juiz tenha de decidir a lide de modo uniforme para todas as partes, com fulcro no artigo 47 do Código de Processo Civil.

Portanto, em caso de procedência do pedido, o provimento jurisdicional condenará os réus ao pagamento da indenização pelos danos morais e patrimoniais provenientes do acidente do trabalho, fixando o quantum devido pela seguradora, como base no valor da apólice e o restante a cargo do empregador. Este também será condenado a pagar o empregado acidentado, subsidiariamente, se houver inadimplência da seguradora.

Finalmente, uma patologia que não pode ser olvidada é a de o empregador não efetivar o seguro, apesar de se tratar de um dever constitucional de contratá-lo em favor de seus empregados.

O regramento será semelhante a todas as demais infrações à ordem jurídica trabalhista, ou seja, receberá as punições administrativas e judiciais. Dentre elas, é possível a imposição judicial de multa por dia de atraso na conclusão desse negócio jurídico para todos os empregados de uma dada empresa, por meio de uma demanda civil pública ajuizada pelo Ministério Público do Trabalho ou por outros entes legitimados a propô-la.

\footnotetext{
${ }^{383}$ O litisconsórcio necessário é a reunião obrigatória de partes nos polos ativo e/ou passivo do processo, desde que o objeto da relação jurídica a que estejam submetidos for incindível ou se houver previsão legal. DINAMARCO, Cândido Rangel. op. cit., v. 2, p. 353.
} 
Independentemente das punições sofridas pelo empregador que não fez o seguro, o empregado poderá ingressar com demanda na Justiça do Trabalho em face dele e pleitear a indenização dos danos decorrentes do acidente do trabalho, com fulcro na responsabilidade objetiva pelo risco profissional.

Entretanto, a regra é que a seguradora, isolada ou conjuntamente, ao solver o débito por conta do empregador (estipulante do contrato de seguro e causador do dano), satisfaça o empregado e extinga a relação obrigacional entre o segurado e a seguradora.

Porém, não é da essência do seguro garantir conduta eivada com o elemento dolo ou culpa. Por isso, após pagar a indenização ao empregado, a seguradora, isoladamente ou em conjunto com a União, volta-se em face do empregador, que não é o segurado, e sim o estipulante. O montante a ser perseguido é aquilo que efetivamente se despendeu na indenização ao segurado, sob pena de enriquecimento sem causa.

\subsubsection{Direito de regresso}

Esse direito de regresso, que é previsto na segunda parte do inciso XXVIII do artigo $7^{\circ}$ da Constituição e que nasce para a seguradora e para a União se o empregador agiu dolosa ou culposamente, não fere o artigo 800 do Código Civil. Esse dispositivo legal veda a sub-rogação à seguradora, no seguro de pessoa, nos direitos e nas ações do segurado ou do beneficiário contra o causador do dano. Na verdade, ele reforça o entendimento de que a seguradora sempre presta sua obrigação ao empregado, e não se isenta, perante ele, dessa responsabilidade, em virtude de conduta dolosa ou culposa do empregador.

Por sua vez, sub-rogação é adimplemento sem extinção da dívida, ou seja, o adimplemento da obrigação é feito por pessoa diversa do devedor, sem ser em nome e por conta deste, com a sucessão do terceiro adimplente no crédito. Assim, tem como efeito o pagamento do credor, contudo, sem a liberação do devedor, que continua com o dever de adimplir a quem adimpliu ${ }^{384}$.

Pela própria definição desse instituto, vê-se que não é possível à seguradora subrogar-se nos direitos do segurado, pois ela lhe efetua o pagamento por conta do próprio

\footnotetext{
${ }^{384}$ MARTINS-COSTA, Judith. Comentários ao novo Código Civil: do direito das obrigações, do adimplemento e da extinção das obrigações. Rio de Janeiro: Forense, 2005.v. 5, t. 1, p. 485.
} 
devedor, isto é, pelo empregador, causador do dano, que foi o estipulante do contrato de seguro. Logo, não há espaço para a sub-rogação no contrato de seguro de acidente do trabalho.

Entretanto, o direito de regresso é previsto, expressamente, pois nasce da conduta dolosa ou culposa do empregador, estipulante do contrato de seguro, em virtude de preceito constitucional. Se o ordenamento jurídico vedar o direito de regresso da seguradora em face do empregador faltoso, não haverá coibição para a conduta irresponsável dele, que não empenhará esforços para corrigir eventuais falhas no meio ambiente laboral. Além disso, o seguro teria prêmios maiores pela baixa competitividade entre as seguradoras, pois poucas se dedicariam a esse ramo.

Portanto, impedir ou criar obstáculos ao direito de regresso da seguradora é involução dos institutos da responsabilidade e, simultaneamente, negar vigência aos princípios ambientais da prevenção e da precaução. Assim, vedar o direito de regresso é estimular a prática do ilícito pela impunidade do agente.

Esse direito de regresso exercido pela seguradora deve ser processado e julgado na Justiça Comum Estadual, pois é fruto de uma relação civil entre o empregador (estipulante do negócio jurídico) e a seguradora.

No caso de riscos extraordinários assumidos em determinadas atividades em que houver participação do Poder Público por meio da União, a competência para tramitar essas demandas será da Justiça Federal, nos termos do artigo 109, inciso I, da Constituição Federal. Assim, não se está diante de causas acidentárias, mas de relações processuais entre as partes contratantes do negócio jurídico do seguro, que buscam um provimento jurisdicional de pagamento das despesas efetuadas pela seguradora, isolada ou conjuntamente com a União, em razão de conduta dolosa ou culposa do causador do dano, que foi o próprio estipulante do contrato, ou seja, o empregador.

Ao contrário da responsabilidade do empregador perante o empregado, que é garantida pelo seguro e é de natureza objetiva, a relação jurídica entre a seguradora e o estipulante é de natureza subjetiva, razão pela qual a perquirição do dolo e da culpa é elemento probatório necessário à lide.

Dessa maneira, trata-se de relações jurídicas de naturezas distintas, sujeitos diversos e competência de ramos diferentes do Poder Judiciário, ou seja, circunstâncias que não permitem a reunião de demandas. 
O direito de regresso de reaver do empregador as despesas efetuadas exige a prova do dolo ou da culpa do causador do dano, ainda que haja inversão do ônus probatório. Em contrapartida, na eventual pretensão do segurado (empregado), que foi resistida pela seguradora ou também pela União, não tem espaço a discussão desses elementos subjetivos (dolo ou culpa), em virtude de ser calcada apenas no risco profissional.

Na hipótese de os bens excutidos do devedor, causador do acidente do trabalho com dolo ou culpa, não serem suficientes para pagar a seguradora ou o ente público com o montante gasto na prestação segurada e, simultaneamente, para indenizar o valor suplementar, a título de dano material e/ou moral do empregado, caso esse exerça seu direito de ação, deve-se preferir o pagamento da dívida faltante do empregado, que foi vítima do acidente. Somente depois de satisfeito esse débito, é que haverá direcionamento de bens à União e à seguradora, respectivamente, para recompensar os valores gastos.

A União também terá preferência à seguradora, pois o interesse que representa nessa atividade econômica é de relevância nacional. Essa ordem de preferência pode ser reforçada com analogia à classificação dos créditos na falência. Assim, os créditos decorrentes de acidentes do trabalho preferem aos tributários que, por seu turno, antepõemse aos quirografários ${ }^{385}$ (artigo 83, da Lei 11101/05).

Portanto, o direito de regresso, fundado no dolo ou na culpa, é instituto com previsão constitucional para o seguro contra acidentes do trabalho e destaca-se como elemento propulsor das melhorias que o empregador deve proceder em seu meio ambiente do trabalho, a fim de garantir a incolumidade física, social e psíquica de seus empregados.

O risco profissional, então, é coberto pelo contrato de seguro e integra-se ao estado anímico do empregador de agir com toda a cautela e diligência no cumprimento das normas de saúde e de segurança do trabalho, sem a mácula da culpa. Como corolário lógico, os princípios da prevenção e precaução são concretizados e os infortúnios trabalhistas reduzidos.

A integração da culpa e do risco na responsabilidade civil dos acidentes do trabalho manifesta-se também nos novos desafios do Direito do Trabalho contemporâneo.

\footnotetext{
${ }^{385}$ Crédito quirografário é aquele sem qualquer garantia e destituído de qualquer privilégio. REQUIÃO, Rubens. Curso de direito falimentar. 17. ed. São Paulo: Saraiva, 1998. v. 1, p. 346.
} 


\subsection{Terceirização e o seguro privado de acidente do trabalho}

As transformações sociais exigem olhares atentos dos juristas para solucioná-los e a terceirização é um desses fenômenos que ganha mais destaque. Veja-se seu enquadramento sob o prisma da integração da culpa e do risco na responsabilidade civil do acidente do trabalho.

De acordo com Maurício Godinho Delgado, a terceirização é o instituto jurídico pelo qual se dissocia a relação econômica de trabalho da relação jurídica correspondente $^{386}$.

No mesmo sentido, Raimundo Simão de Melo diz que terceirização é um processo em que consiste transferir para as empresas terceirizadas as atividades secundárias do tomador de serviços, conhecidas como atividades-meio, para que este se dedique à atividade-fim que é a principal ${ }^{387}$.

Isso posto, entende-se por terceirização o fenômeno destinado a descentralizar a atividade produtiva da empresa, que não constitua sua finalidade principal, para outra, que desenvolverá os serviços auxiliares, com o escopo de melhorar sua eficiência no mercado.

No Brasil, não existe um regramento específico para esse fenômeno, aplicando-se apenas o entendimento sumulado do Tribunal Superior do Trabalho ${ }^{388}$.

\footnotetext{
${ }^{386}$ DELGADO, Maurício Godinho. op. cit., p. 428.

${ }^{387}$ MELO, Raimundo Simão de. op. cit., p. 260.

${ }^{388}$ Súmula 331 do Tribunal Superior do Trabalho:
}

\section{CONTRATO DE PRESTAÇÃO DE SERVIÇOS. LEGALIDADE.}

I - A contratação de trabalhadores por empresa interposta é ilegal, formando-se o vínculo diretamente com o tomador dos serviços, salvo no caso de trabalho temporário (Lei nº 6.019, de 03.01.1974).

II - A contratação irregular de trabalhador, mediante empresa interposta, não gera vínculo de emprego com os órgãos da Administração Pública direta, indireta ou fundacional (art. 37, II, da CF/1988).

III - Não forma vínculo de emprego com o tomador a contratação de serviços de vigilância (Lei $\mathrm{n}^{\circ} 7.102$, de 20.06.1983) e de conservação e limpeza, bem como a de serviços especializados ligados à atividademeio do tomador, desde que inexistente a pessoalidade e a subordinação direta.

IV - O inadimplemento das obrigações trabalhistas, por parte do empregador, implica a responsabilidade subsidiária do tomador dos serviços quanto àquelas obrigações, desde que haja participado da relação processual e conste também do título executivo judicial.

V - Os entes integrantes da Administração Pública direta e indireta respondem subsidiariamente, nas mesmas condições do item IV, caso evidenciada a sua conduta culposa no cumprimento das obrigações da Lei n. ${ }^{\circ}$ 8.666, de 21.06.1993, especialmente na fiscalização do cumprimento das obrigações contratuais e legais da prestadora de serviço como empregadora. A aludida responsabilidade não decorre de mero inadimplemento das obrigações trabalhistas assumidas pela empresa regularmente contratada.

VI - A responsabilidade subsidiária do tomador de serviços abrange todas as verbas decorrentes da condenação referentes ao período da prestação laboral. SUPERIOR TRIBUNAL DO TRABALHO. Súmula 331. Disponível em: <http://www3.tst.jus.br/jurisprudencia/Sumulas_com_indice/Sumulas_Ind_301_350.html. Acesso em: 22 nov. 2012. 
Devido à sua insuficiência para regular a responsabilidade civil do acidente do trabalho, apresentar-se-á uma solução contextualizada no pensamento de que o empregado tem direito ao contrato de seguro formalizado pelo empregador para garantir sua indenização nos infortúnios relacionados à sua atividade profissional.

O trabalhador celebra um contrato de trabalho com a empresa terceirizada para prestar serviços no meio ambiente laboral de uma outra empresa, que é chamada de tomadora de serviços. Trata-se de uma descentralização empresarial que se transfere para um terceiro as tarefas que não seriam sua atividade principal e, assim, alcançar-se-ia a eficiência do modo de produção.

Nessa situação, a empresa terceirizada tem a obrigação de contratar o seguro privado para seus empregados, considerando os riscos que eles estarão expostos na empresa tomadora de serviços. Destarte, ocorrendo o infortúnio, o empregado terceirizado teria sua indenização garantida pela seguradora, isoladamente ou em conjunto com a União, que foi contratada por seu empregador. Essa responsabilidade é fundada no risco proveito, tendo-se em vista as vantagens auferidas pela empresa terceirizada que se submete aos ônus respectivos.

Todavia, esse acidente do trabalho pode ser fruto do descumprimento de normas ambientais que incumbia ao empregador observá-las. A terceirização, por interferir nos sujeitos envolvidos na relação de trabalho, faz com que algumas obrigações contratuais do empregador, empresa terceirizada, sejam transferidas para a tomadora de serviços, haja vista que o labor será desenvolvido no meio ambiente desta última. Essa transferência obrigacional é feita pelo contrato de natureza civil de prestação de serviços entre a empresa terceirizada e a tomadora. Dessa forma, tanto a empresa terceirizada quanto a tomadora de serviços se impõem a missão de prevenir acidentes do trabalho.

A própria empresa terceirizada tem o dever contratual de zelar pela saúde e pela integridade física e psíquica de seus trabalhadores, como o fornecimento de equipamentos de proteção individual. Contudo, existem certas medidas ambientais, que interferem no estabelecimento da tomadora e, por isso, essa também tem o dever de segurança com seus terceirizados. Outrossim, aduz que a tomadora de serviços pode ser considerada como 
comitente dos serviços prestados pela empresa terceirizada e, consequentemente, sua responsabilidade será objetiva, nos termos do artigo 932, III do Código Civil ${ }^{389}$.

Assim, em caso de descumprimento das normas ambientais de saúde e segurança do trabalho, a seguradora, sozinha ou em parceria com a União, poderá exercer seu direito de ação em face da tomadora dos serviços e/ou da empresa terceirizada, com base no artigo 932, inciso III do Código Civil, para reaver os valores pagos a título de danos morais e materiais aos empregados terceirizados, com a exigência de provar o dolo ou a culpa da tomadora e/ou da terceirizada em observar as normas de saúde e de segurança do trabalho.

Nesse entendimento, compor-se-á ou não o polo passivo dessa demanda, aquele a quem incumbia o dever de segurança ou mesmo de fiscalizar o cumprimento por parte do outro contratante, sempre analisado de modo abstrato, pois o Código de Processo Civil pátrio adotou a teoria eclética ${ }^{390}$ quanto às condições da ação.

Assim, caso o dever fosse somente a cargo da terceirizada, como o fornecimento de equipamentos de proteção individual, sempre será possível a participação da empresa tomadora no polo passivo, além da terceirizada, pois aquela tinha também o dever de fiscalizar esta. Nos termos do Código Civil, a responsabilidade da tomadora será objetiva pelos danos causados pela terceirizada e, ao mesmo tempo, solidária (artigo 942 do Código Civil $^{391}$ ). Por outro lado, se o dever de proteção era da tomadora, somente ela deverá figurar no polo passivo da demanda regressiva.

Portanto, a integração da culpa e do risco na responsabilidade civil do acidente do trabalho é o caminho para garantir a indenização às vítimas por meio do seguro privado, bem como para efetivar a prevenção e a precaução no ambiente laboral, inclusive, nos casos de terceirização, conforme ficou demonstrado.

\footnotetext{
${ }^{389}$ Artigo 932, inciso III, do Código Civil: "São também responsáveis pela reparação civil: o empregador ou comitente, por seus empregados, serviçais e prepostos, no exercício do trabalho que lhes competir, ou em razão dele". CONGRESSO NACIONAL. Código Civil. Disponível em: $<$ http://www.planalto.gov.br/ccivil_03/Leis/2002/L10406.htm>. Acesso em: 25 nov. 2012.

${ }^{390} \mathrm{De}$ acordo com a teoria eclética, as condições da ação são requisitos para existência do processo, cuja falta acarreta a extinção sem julgamento do mérito. DINAMARCO, Cândido Rangel. op. cit., v. 1, p. 316.

${ }^{391}$ Artigo 942 do Código Civil: "Os bens do responsável pela ofensa ou violação do direito de outrem ficam sujeitos à reparação do dano causado; e, se a ofensa tiver mais de um autor, todos responderão solidariamente pela reparação. Parágrafo único. São solidariamente responsáveis com os autores os coautores e as pessoas designadas no art. 932”. CONGRESSO NACIONAL. Código Civil, cit.
} 


\section{CONCLUSÕES}

O trabalho livre e assalariado está inserido na etapa evolutiva do ser humano e traz, em seu bojo, a tutela da saúde e do meio ambiente. Trata-se de bens jurídicos que conferem direitos e deveres aos homens por meio de normas, que se revelam por regras ou por princípios, tanto no âmbito interno quanto na esfera internacional.

Essas normas de saúde e de meio ambiente são consubstanciadas em deveres jurídicos impostos aos Poderes Públicos e à sociedade (incluídos os empregadores) de praticar determinadas condutas ou de não realizá-las, norteadas pelo afastamento dos riscos conhecidos e dos hipotéticos, com o escopo final de preservação e de melhoria da vida humana em todas as suas dimensões. Esses deveres implicam, reflexamente, em direitos subjetivos aos indivíduos de exigir a realização dessas condutas em busca de uma vida com plenitude.

No âmbito das relações de trabalho, um dos efeitos da falha dessa rede de proteção é o acidente do trabalho, ou seja, aquele evento, súbito ou paulatino, que causa danos à saúde do trabalhador e que seja proveniente do próprio exercício da atividade profissional.

Esses danos, por sua vez, exigem indenização pelo respectivo causador, que é o juridicamente responsável. Nos primórdios da responsabilidade, perquiria-se a culpa. No entanto, o empregado não dispunha de elementos para demonstrar que o comportamento de seu empregador era caracterizado pelo descuido da preservação da saúde e do meio ambiente do trabalho e, por isso, os acidentes não eram significativamente indenizados.

O sentimento de injustiça pedia uma mudança social, uma vez que aquele que auferia vantagens de sua atividade deveria, em contrapartida, assumir os ônus correlatos. Dessa maneira, o ordenamento jurídico, atento às vicissitudes do mundo do ser, perseguiu a responsabilidade pelo risco profissional, ou seja, o empregador passou a ser responsável por sua atividade proveitosa, e não por sua culpa.

A mutilação dos trabalhadores causou também preocupações aos Estados, haja vista que a força de trabalho é a fonte de subsistência do empregado e de seus familiares, assim como se subsome ao elo produtivo da sociedade. Então, com o escopo de manterem a paz social e de buscarem o bem comum, os Estados organizaram sistemas de seguro 
social a partir da identificação das dificuldades do povo, cuja solução foi dada por meio do auxílio mútuo, isto é, da solidariedade social.

Os acidentes do trabalho estão abarcados pelo sistema de seguro social no Brasil, a partir de uma interpretação constitucional em coerência à ordem social. $\mathrm{O}$ artigo $7^{\circ}$, inciso XXVIII, da Constituição Federal previu um seguro de acidente do trabalho a cargo do empregador, sem excluir a indenização a que está sujeito em caso de dolo ou culpa.

O dever do empregador em contribuir para o seguro social não é tarefa exclusiva e poderá ser feita pelo Estado e pelos próprios trabalhadores, em consonância com a regra de um financiamento tripartite, ou seja, Estado, empregadores e trabalhadores ajudar-se-ão reciprocamente.

Outrossim, o artigo 201, inciso I, da Constituição estabelece que a previdência social cobrirá, dentre outros, os seguintes eventos: doença, invalidez e morte. Destarte, a invalidez e a morte podem ser efeitos do acidente, ao passo que a doença poderá ser o próprio acidente em si (doença ocupacional) ou, apenas, um resultado dele.

Em obediência ao princípio da precaução de danos, o Instituto Nacional do Seguro Social (INSS) pode promover uma demanda regressiva em face do empregador culpado pelo acidente, ou seja, a solidariedade não abrange aquele que não cumpriu o seu dever de segurança.

A proteção do INSS limita-se ao caráter alimentar, isto é, não indeniza a vítima de todos os danos, morais ou patrimoniais. Para completar essa indenização, o empregado socorre-se dos postulados de direito civil.

A própria linha evolutiva da responsabilidade civil permite concluir que, nos acidentes do trabalho, os fundamentos dessa indenização são o contrato de trabalho e o risco da atividade previstos no artigo $2^{\circ}$ da Consolidação das Leis do Trabalho.

$\mathrm{O}$ acidente do trabalho desencadeia-se no âmbito de um contrato de trabalho. No curso desse contrato, emergem prestações secundárias autônomas que coexistem ao lado das prestações principais de dar o salário e de fazer o serviço. Essas prestações secundárias correspondem ao cumprimento das normas de saúde e de segurança do trabalho, pois o empregado tem o direito público subjetivo de exigir um meio ambiente do trabalho salubre. Além disso, o empregador tem o dever instrumental de proteger o empregado dos riscos de danos à sua pessoa e ao seu patrimônio. Esse dever instrumental consubstancia-se no dever de segurança, alicerçado na boa-fé. 
A não realização da prestação imputada ao devedor enseja a inexecução contratual que, por seu turno, faz surgir uma nova obrigação de indenizar os prejuízos resultantes dessa conduta.

O elemento volitivo é dispensável, ou seja, a busca do responsável pelo inadimplemento contratual é baseada no risco proveito, na modalidade profissional. A justificativa remete ao texto consolidado porque aquele que aufere vantagens com o desempenho de sua atividade deve suportar os ônus decorrentes como medida de justiça.

Embora a culpa seja prescindível para determinar o responsável, a causa dos danos deve ser perseguida. Dessa forma, o nexo de causalidade entre o dano e o fato do empregador é indispensável. Conquanto na responsabilidade alimentar do INSS o nexo é mais abrangente e inclui circunstâncias não relacionadas diretamente ao trabalho, na civil, o liame jurídico é estreito com a atividade desenvolvida pelo empregador.

Assim, entende-se admissível as causas excludentes do nexo causal, quais sejam, caso fortuito, força maior, culpa de terceiro ou exclusiva da vítima, desde que sejam estranhas à atividade empresarial. Não obstante, os eventos danosos, resultantes da falta do dever de segurança por parte do empregador, são considerados fortuitos internos e, consequentemente, acobertados pelo risco do negócio.

Em simetria com a responsabilidade previdenciária que liga o risco à responsabilidade objetiva e à garantia de pagamento do benefício de caráter alimentar em razão de solidariedade social, a responsabilidade civil também exige que o empregador assuma os riscos de seu empreendimento e não permite que o empregado submeta-se às intempéries da atividade, sempre norteados pela cooperação recíproca.

Logo, propõe-se um seguro privado a cargo do empregador, haja vista que a cobertura dos riscos de acidentes do trabalho será atendida, concorrentemente, pela previdência social e pelo setor privado, com respaldo nos artigos $7^{\circ}$, inciso XXVIII, e 201, $\S 10$, ambos da Constituição Federal. Dessa forma, o artigo $7^{\circ}$, inciso XXVIII, tem sua faceta trabalhista ao lado da previdenciária, conforme demonstrado.

Assim, o empregador tem o dever de celebrar um contrato de seguro de acidente pessoal em favor de seus empregados, que serão os segurados. Os empregados ou seus familiares serão os beneficiados desse seguro, pois com a redução e/ou perda da capacidade laborativa, haverá uma diminuição ou até a extinção das utilidades produzidas pela força de trabalho danificada. Entende-se que esse dever do empregador se estende 
além da vigência da relação de emprego, pois muitas doenças ocupacionais manifestam-se em momento ulterior, variando esse prazo conforme o risco empresarial. Contudo, se a ciência da incapacidade laborativa ocorrer após a cessação desse contrato de seguro de acidente pessoal, o empregador será responsável pela indenização civil até a pretensão ser fulminada pela prescrição.

Entrementes, o seguro leva ao desaparecimento do responsável, haja vista que os danos serão suportados pelo segurador. Para combater esse efeito e o eventual descuido com as normas ambientais do trabalho, a segunda parte do inciso XXVIII do artigo $7^{\circ}$ da Constituição prevê que o empregador será responsável se incorrer em dolo ou em culpa. Será a seguradora que exercerá seu direito de regresso em face do empregador descuidado. Por isso, ele será obrigado a cumprir as normas de medicina e de segurança do trabalho e, assim, implementar o princípio da precaução no ambiente do trabalho por medidas capazes de afastar os riscos hipotéticos aptos a causar danos graves e irreversíveis.

Então, a responsabilidade pelo risco profissional torna-se inteira pela culpa do empregador que é buscada pela seguradora em demanda regressiva.

Para essa integração entre a culpa e o risco, o ordenamento previu que as seguradoras sejam constituídas em forma de sociedade anônima ou cooperativas, a fim de conferir maior solvabilidade das indenizações, ao lado do cosseguro com o Poder Público para aquelas atividades que causam um risco acima dos cálculos estatísticos normais, mas sejam imprescindíveis para o progresso social. A União será o ente federado capaz de atuar nesses seguros em razão do relevante interesse coletivo envolvido, nos termos do artigo 173 da Constituição Federal. Esses são mecanismos estáticos que garantem a integração.

Contudo, tem-se os mecanismos dinâmicos que correspondem ao exercício do direito de ação conferido à seguradora, sozinha ou em conjunto com a União, de postular os valores pagos a título de indenização por danos moral e material aos empregados acidentados, se o empregador agiu de modo culposo ou doloso no tocante às normas de meio ambiente do trabalho, sobretudo.

Até o fenômeno da terceirização abarca essa integração, ao ser fixado o direito do trabalhador terceirizado ao contrato de seguro privado e a possibilidade de demanda regressiva em face do tomador de serviços e/ou da empresa terceirizada, conforme os deveres de segurança de cada uma das partes. 
Portanto, infere-se que a integração da culpa e do risco na responsabilidade civil do acidente do trabalho atende, simultaneamente, à equidade de indenização do empregado e ao respeito às normas do meio ambiente do trabalho, sobretudo, os princípios da prevenção e precaução, por meio do elo de ligação do seguro privado. 


\section{REFERÊNCIAS}

ABBAGNANO, Nicola. Dicionário de filosofia. 2. ed. São Paulo: Martins Fontes, 1998. ABRANCHES, Fernando Figueiredo de. Do seguro mercantilista de acidentes do trabalho ao seguro social. São Paulo: Sugestões Literárias, 1974.

ALEXY, Robert. Teoria dos direitos fundamentais. Trad. Virgílio Afonso da Silva. São Paulo: Malheiros Ed., 2008.

ALMEIDA, Cleber Lúcio de. Responsabilidade civil do empregador e acidente de trabalho. Belo Horizonte: Dey Rey, 2003.

ALPA, Guido; BESSONE, Mario. La responsabilità civile. 2. ed. Milano: Giuffrè, 1980. v. 2.

ALVES, José Carlos Moreira. Direito romano. 6. ed. Rio de Janeiro: Forense, 1998. v. 2.

ALVIM, Agostinho. Da inexecução das obrigações e suas consequências. 3. ed. Rio de Janeiro: Jurídica e Universitária, 1965.

ALVIM, Pedro. O contrato de seguro. Rio de Janeiro: Forense, 1983.

ANAMATRA. I Jornada de Direito Material e Processual do Trabalho. Enunciado $n^{o} 37$. Disponível em: $<$ http://www.anamatra.org.br/jornada/enunciados/enunciados_aprovados.cfm>. Acesso em: 19 nov. 2010.

ASSEMBLEIA DO ESTADO DE RONDÔNIA. Constituição do Estado de Rondônia. Disponível em: <http://www.ale.ro.gov.br/portal/Mostrar.aspx?idConteudo=3718>. Acesso em: 24 set. 2012.

ASSEMBLEIA DO ESTADO DE SÃO PAULO. Constituição do Estado de São Paulo. Disponível em: <http://www.al.sp.gov.br/repositorio/legislacao/constituicao/1989/constituicao\%20de\%200 5.10.1989.htm>. Acesso em: 24 set. 2012.

AULETE, Caldas. iDicionárioAulete. Disponível em: <http://aulete.uol.com.br/integrar>. Acesso em: 14 dez. 2012.

AZEVEDO, Álvaro Villaça. Teoria geral das obrigações. 8. ed. São Paulo: Ed. Revista dos Tribunais, 2000.

BACHOF, Otto. Normas constitucionais inconstitucionais? Trad. José Manuel M. Cardoso da Costa. Coimbra: Almedina, 1994. 
BARROS, A. B. Buys de. O seguro social no direito brasileiro. Rio de Janeiro: Max Limonad, 1944. (Coleção de Direito do Trabalho organizada por Dorval de Lacerda e Evaristo de Morais Filho, v. 8).

BEATI. Ricardo C. Accidentes por riesgos del trabajo. In: CABANA, Roberto M. López (coord). Responsabilidad civil por accidents. Buenos Aires: Abeledo-Perrot, s/d.

BECK, Ulrich. Sociedade de risco: rumo a uma outra modernidade. Trad. Sebastião Nascimento. São Paulo: Ed. 34, 2010.

BELFORT, Fernando José Cunha. A responsabilidade objetiva do empregador nos acidentes de trabalho. São Paulo: LTr, 2010.

BELMONTE, Alexandre Agra. Curso de responsabilidade trabalhista: danos morais e patrimoniais nas relações de trabalho. 2. ed. São Paulo: LTr, 2009.

BELTRAN, Ari Possidonio. Da responsabilidade subjetiva e objetiva do empregador por acidente do trabalho, ante as disposições do novo Código Civil. Revista do Departamento de Direito do Trabalho e da Seguridade Social, Faculdade de Direito da USP, São Paulo, v. 1, n. 1, jan./jun. 2006.

BEVERIDGE, William. Social insurance and allied services: report by Sr. William Beveridge. New York: The Macmillan Company, 1942.

BEVILAQUA, Clovis. Código Civil dos Estados Unidos do Brasil. 4. ed. Rio de Janeiro: Francisco Alves, 1934.

BOBBIO, Norberto. A era dos direitos. Trad. Carlos Nelson Coutinho. 10. ed. Rio de Janeiro: Campus, 1992.

BONAVIDES, Paulo. Curso de direito constitucional. 12. ed. São Paulo: Malheiros Ed., 2002.

BORRI, Lorenzo. Trattato di infortunistica. Milano: Società Editrice Libraria, 1918. v. 1.

BORTOLOTTO, Guido. Infortuni sul lavoro e malattie professionali. Milano: Libraio Della Real Casa, 1937.

BULGARELLI, Waldirio. Sociedades comerciais: sociedades civis e sociedades cooperativas; empresas e estabelecimento commercial. 9. ed. São Paulo: Atlas, 2000.

CANOTILHO, José Joaquim Gomes. Direito constitucional e teoria da Constituição. 7. ed. Coimbra: Almedina, 2007.

. Estudos sobre direitos fundamentais. São Paulo: Ed. Revista dos Tribunais, 2008.

CARDONE, Marly A. Seguro social e contrato de trabalho. São Paulo: Saraiva, 1973. 
CARTA ENCÍCLICA "RERUM NOVARUM". Vaticano. Disponível em: <http://www.vatican.va/holy_father/leo_xiii/encyclicals/documents/hf_lxiii_enc_15051891_rerum-novarum_po.html>. Acesso em: 21 abr. 2011.

CARVAlHOSA, Modesto. Comentários à Lei de Sociedades Anônimas. 3. ed. São Paulo: Saraiva, 2000. v. 1.

CASTRO, Carlos Alberto Pereira de; LAZZARI, João Batista. Manual de direito previdenciário. 12. ed. Florianópolis: Conceito Editorial, 2010. Manual de direito previdenciário. 14. ed. Florianópolis: Conceito Editorial, 2012.

CAUPERS, João. Os direitos fundamentais dos trabalhadores e a Constituição. Lisboa: Almedina, 1985.

CAVALIERI FILHO, Sérgio. Programa de responsabilidade civil. 6. ed. São Paulo: Malheiros Ed., 2005.

CECÍlLIA, Silvana Louzada Lamattina. Responsabilidade do empregador por danos à saúde do trabalhador. São Paulo: LTr, 2008.

IL CODICE Civile Italiano. Disponível em: $<$ http://www.jus.unitn.it/cardozo/obiter_dictum/codciv/Lib4.htm>. Acesso em: 10 nov. 2012.

COMPARATO, Fábio Konder. A afirmação histórica dos direitos humanos. 2. ed. São Paulo: Saraiva, 2001.

; SALOMÃO FILHO, Calixto. O poder de controle na sociedade anônima. 4. ed. Rio de Janeiro, 2005.

CONGRESSO NACIONAL. Código Civil. Disponível em: <http://www.planalto.gov.br/ccivil_03/Leis/2002/L10406.htm>. Acesso em: 25 nov. 2012. Lei 8213/91. Disponível em: <http://www.planalto.gov.br/ccivil_03/Leis/L8213cons.htm>. Acesso em: 25 out. 2012. CONSELHO DA JUSTIÇA FEDERAL. I Jornada de Direito Civil. Enunciado $n^{\circ} 50$. Disponível em: <http://daleth.cjf.jus.br/revista/enunciados/IJornada.pdf>. Acesso em: 17 mar. 2012.

- I Jornada de Direito Civil. Enunciado $n^{o}$ 38. Disponível em: <http://daleth.cjf.jus.br/revista/enunciados/IJornada.pdf>. Acesso em: 19 nov. 2012. 
CONSELHO DA JUSTIÇA FEDERAL. IV Jornada de Direito Civil. Enunciado 379. Disponível em: <http://www.jf.jus.br/cjf/CEJ-Coedi/jornadas-cej/enunciados-aprovadosda-i-iii-iv-e-v-jornada-de-direito-civil/jornadas-de-direito-civil-enunciados-aprovados $>$. Acesso em: 11 nov. 2012.

CONSELHO FEDERAL DE MEDICINA. Resolução 1.488, de 6 de março de 1998. Disponível em: <http://www.portalmedico.org.br/resolucoes/CFM/1998/1488_1998.htm>. Acesso em: 20 abr. 2012.

CORDEIRO, António Menezes. Da boa-fé no direito civil. Coimbra: Almedina, 2007.

CORREIA, Marcus Orione Gonçalves; CORREIA, Érica Paula Barcha. Curso de direito da seguridade social. São Paulo, 2001.

CORTE DE CASSAÇÃO NA FRANÇA. SEGUNDA CÂMARA CIVIL. Aresto n ${ }^{\circ}$ 0968.764, de 23 de setembro de 2010. Disponível em: <http://www.editions-tissot.fr/droittravail/jurisprudence-sante-securite-fiche-print.aspx?occId=141>. Acesso em: 15 nov. 2012.

COUR DE CASSATION. Rapport annuel. Rapport 2011. Troisiéme partie. Chapitre 2: Sécurité sociale. Disponível em: $<$ http://www.courdecassation.fr/publications_cour_26/rapport_annuel_36/rapport_2011_42 12/troisieme_partie_etude_risque_4213/charge_risque_4247/repartition_charge_4254/chap itre_2._securite_sociale_22818.html>. Acesso em: 23 out. 2012.

DALLAGRAVE NETO, José Affonso. Responsabilidade civil no direito do trabalho. 4. ed. São Paulo: LTr, 2010.

DALLARI, Sueli Gandolfi; NUNES JÚNIOR, Vidal Serrano. Direito sanitário. São Paulo: Ed. Verbatim, 2010.

; VENTURA, Deisy de Freitas Lima. O princípio da precaução, dever do Estado ou protecionismo disfarçado? São Paulo em Perspectiva, São Paulo, v. 16, n. 2, 2002.

DELGADO, Maurício Godinho. Curso de direito do trabalho. 4. ed. São Paulo: LTr, 2005. DERANI, Cristiane. Direito ambiental econômico. 2. ed. São Paulo: Max Limonad, 2001.

DIAS, José de Aguiar. Da responsabilidade civil. 5. ed. Rio de Janeiro: Forense, 1973. v. 1 e v. 2.

DINAMARCO, Cândido Rangel. Instituições de direito processual civil. 4. ed. São Paulo: Malheiros Ed., 2004. v. 1 e v. 2.

DINIZ, Maria Helena. Curso de direito civil brasileiro: responsabilidade civil. 24. ed. São Paulo: Saraiva, 2010. v. 7. 
DURAND, Paul. La politique contemporaine de sécurité sociale. Paris: Dalloz, 1953.

DWORKIN, Ronald. Levando os direitos a sério. Trad. Jefferson Luiz Camargo. São Paulo: Martins Fontes, 2007.

FERRAZ JÚNIOR, Tércio Sampaio. Introdução ao estudo do direito: técnica, decisão, dominação. 2. ed. São Paulo: Atlas, 1994.

FERREIRA, Aurélio Buarque de Holanda. Dicionário Aurélio da língua portuguesa. 5. ed. Curitiba: Positivo, 2010.

FERREIRA FILHO, Manoel Gonçalves. Direitos humanos fundamentais. 3. ed. São Paulo: Saraiva, 1999.

FIORILlO, Celso Antonio Pacheco. Curso de direito ambiental brasileiro. 7. ed. São Paulo: Saraiva, 2006.

FISCHER, Hans Albrecht. A reparação dos danos no direito civil. Trad. António de Arruda Ferrer Correia. Coimbra: Arménio Amado, 1938.

GAGliANO, Paulo Stolze; PAMPLONA FILHO, Rodolfo. Novo curso de direito civil: responsabilidade civil. 4. ed. São Paulo: Saraiva, 2006.

GARCIA, Gustavo Filipe Barbosa. Acidentes do trabalho: doenças ocupacionais e nexo técnico epidemiológico. 4. ed. São Paulo: Método, 2011.

GODOY, Claudio Luiz Bueno de. Responsabilidade civil pelo risco da atividade. 2. ed. São Paulo: Saraiva, 2010.

GOMES, Orlando. Contratos. 21. ed. Rio de Janeiro: Forense, 2000.

. Obrigações. 13. ed. Rio de Janeiro: Forense, 2000.

GONÇALVES, Carlos Roberto. Comentários ao Código Civil: parte especial: direito das obrigações. São Paulo: Saraiva, 2003. (Coordenador da Coleção, v. 11, Antônio Junqueira de Azevedo).

GONÇALVES. Luiz da Cunha. Responsabilidade civil pelos acidentes de trabalho e doenças profissionais. Coimbra: Coimbra Ed., 1939.

GRAU, Eros Roberto. Ensaio e discurso sobre interpretação/aplicação do direito. São Paulo: Malheiros Ed., 2002.

GURGEL FILHO, Milton; FERNANDES, Marcus Frederico B. Dano moral e o seguro de responsabilidade civil. Revista do Advogado, Sao Paulo, n. 47, p. 30-32, mar. 1996. 
HIRONAKA, Giselda Maria Fernandes Novaes. Responsabilidade pressuposta. Belo Horizonte: Del Rey, 2005.

HUNGRIA, Nelson. Comentários ao Código Penal. 4. ed. Rio de Janeiro: Forense, 1958.

KANT, Immanuel. Crítica da razão pura. Trad. Manuela Pinto dos Santos; Morujão, Alexandre Fradique. 4. ed. Lisboa: Fundação Calouste Gulbenkian, 1997.

KELSEN, Hans. Teoria pura do direito. 6. ed. São Paulo: Martins Fontes, 1998.

LAFER, Celso. A reconstrução histórica dos direitos humanos. São Paulo: Companhia das Letras, 2001.

LEAL, Antonio Luiz da Câmara. Da prescrição e da decadência. Rio de Janeiro: Forense, [s.d.].

LEGIFRANCE. Disponível em: <http://www.legifrance.gouv.fr>. Acesso em: 23 out. 2012.

LEITE, Celso Barroso. A proteção social no Brasil. São Paulo: Saraiva, 1972.

LIMA, Alvino. Culpa e risco. 2. ed. Atualizada por Ovídio Rocha Barros Sandoval. São Paulo: Ed. Revista dos Tribunais, 1998.

LOPEZ, Teresa Ancona. O dano estético: responsabilidade civil. 3. ed. São Paulo: Ed. Revista dos Tribunais, 2004.

Latin, 2010.

LOURENÇO, Paula Meira. Os danos punitivos. Revista da Faculdade de Direito da Universidade de Lisboa, Coimbra, v. 43, n. 2, 2002.

MACHADO, Paulo Affonso Leme. Direito ambiental brasileiro. 14. ed. São Paulo: Malheiros Ed., 2006.

MACIEL, Fernando. Ações regressivas acidentárias. São Paulo: LTr, 2010.

MAGALHÃES. José Maria Vilhena de. Seguro contra acidentes de trabalho. Lisboa: Empresa Lusitana Ed., 1913.

MALINGREY, Philippe. Cadre juridique de la prevention et de la reparation des risques profissionnels. Paris: Lavoisier, 2009.

MARANHÃO, Délio. Contrato de trabalho. In: SÜSSEKIND, Arnaldo; MARANHÃO, Délio; VIANNA, Segadas; TEIXEIRA, Lima. Instituições de direito do trabalho. 20. ed. São Paulo: LTr, 2002. v. 1. 
MARCHI, Eduardo C. Silveira. Guia de metodologia jurídica (teses, monografias e artigos). Lecce: Edizioni del Grifo, 2001.

MARTINS, Fran. Contratos e obrigações comerciais. 15. ed. Rio de Janeiro: Forense, 2001.

MARTINS-COSTA, Judith. A boa-fé no direito privado. São Paulo: Ed. Revista dos Tribunais, 2000.

. Comentários ao novo Código Civil: do direito das obrigações, do adimplemento e da extinção das obrigações. Rio de Janeiro: Forense, 2005.v. 5, t. 1.

Comentários ao novo Código Civil: do inadimplemento das obrigações: arts. 389 a 420. Rio de Janeiro: Forense, 2004. (Coleção Comentários ao Novo Código Civil - Coord. Sálvio de Figueiredo Teixeira).

MAZEAUD, Jean; MAZEAUD, Leon. Traité théorique e pratique de la responsabilité civile délictuelle e contractuelle. Préface par Henri Capitant. 4. ed. Paris: Livrairie du Recueil Sirey, 1947. t. 1.

MEDAUAR, Odete. Direito administrativo moderno. 5. ed. São Paulo: Ed. Revista dos Tribunais, 2001.

MEIRELLES, Hely Lopes. Direito administrativo brasileiro. 15. ed. São Paulo: Ed. Revista dos Tribunais, 1990.

. Os poderes do administrador público. Revista de Direito Administrativo, Rio de Janeiro, Seleção histórica, p. 327-343, 1945-1995.

MELlO, Celso Antônio Bandeira de. Conteúdo jurídico do princípio da igualdade. 3. ed. São Paulo: Malheiros Ed., 2002.

. Curso de direito administrativo. 17. ed. São Paulo: Malheiros Ed., 2004.

MELlO, Marcos Bernardes de. Teoria do fato jurídico: plano da existência. 12. ed. São Paulo: Saraiva, 2003.

MELO, Raimundo Simão de. Direito ambiental do trabalho e a saúde do trabalhador. 2. ed. São Paulo: LTr, 2006.

MENDES, René. Medicina do trabalho e doenças profissionais. São Paulo: Sarvier, 1980.

MINISTÉRIO DO TRABALHO E EMPREGO. NR 5. Disponível em: <portal.mte.gov.br/data/files/.../nr_05.pdf>. Acesso em: 20 set. 2012. 
MINISTÉRIO DO TRABALHO. Portaria 3214/78. Disponível em: <http://www010.dataprev.gov.br/sislex/paginas/63/mte/1978/3214.htm>. Acesso em: 24 set. 2012.

MORAES, Alexandre. Direito constitucional. 17. ed. São Paulo: Atlas, 2005.

NANNI, Giovanni Ettore. Responsabilidade no acidente do trabalho. Gazeta Mercantil, 13 out. 2003. Caderno Legal \& Jurisprudência, p. 1.

NORONHA, Fernando. Direito das obrigações. 3. ed. São Paulo: Saraiva, 2010. v. 1.

OLIVEIRA, José de. Acidentes do trabalho: teoria, prática, jurisprudência. 2. ed. São Paulo: Saraiva, 1992.

OLIVEIRA, Paulo Eduardo Vieira. O dano pessoal no direito do trabalho. 2. ed. São Paulo: LTr, 2010.

OLIVEIRA, Sebastião Geraldo. Indenizações por acidente do trabalho ou doença ocupacional. 2. ed. São Paulo: LTr, 2006.

ORGANIZAÇÃO DAS NAÇÕES UNIDAS. Declaração de Estocolmo sobre o meio ambiente humano. Disponível em: <http://www.direitoshumanos.usp.br/index.php/MeioAmbiente/declaracao-de-estocolmo-sobre-o-ambiente-humano.html>. Acesso em: 26 set. 2012.

- Declaração Sobre Meio Ambiente e Desenvolvimento. Disponível em: $<$ http://www.direitoshumanos.usp.br/index.php/Meio-Ambiente/declaracao-sobre-meioambiente-e-desenvolvimento.html>. Acesso: 19 out. 2012.

ORGANIZAÇÃO INTERNACIONAL DO TRABALHO. Convenção 155. Disponível em: <http://www.institutoamp.com.br/oit155.htm>. Acesso em: 21 abr. 2011.

Convenção 187. Disponível em: <http://www.institutoamp.com.br/oit187.htm>. Acesso em: 16 set. 2012.

ORGANIZAÇÃO MUNDIAL DA SAÚDE. Constituição da Organização Mundial da Saúde. Disponível em: <http://www.onu.org.br/a-onu-em-acao/a-onu-e-a-saude>. Acesso em: 29 out. 2012.

PADILHA, Norma Sueli. Do meio ambiente do trabalho equilibrado. São Paulo: LTr, 2002 .

PEREIRA, Caio Mário da Silva. Instituições de direito civil: teoria geral das obrigações. 19. ed. Rio de Janeiro: Forense, 2002. v. 1 e v. 2. 
PICARELLI, Márcia Flávia Santini. Do seguro social à seguridade social: desafios e paradoxos. Revista de Previdência Social, São Paulo, v. 16, n. 145, p. 1091-1097, dez. 1992.

PIRSON, Roger; VILLÉ, Albert de. Traité de la responsabilidade civile extracontractuelle. Paris: Générale de Droit e de Jurisprudence, 1935. t. 2.

PLÁ RODRIGUEZ, Américo. Princípios de direito do trabalho. 3. ed. São Paulo: LTr, 2004.

PODER EXECUTIVO. Decreto-Lei 73/66. Disponível em: <http://www.planalto.gov.br/ccivil_03/decreto/1950-1969/d61867.htm>. Acesso em: 26 nov. 2012.

PONTES DE MIRANDA, Francisco Cavalcanti. Tratado de direito privado. 3. ed. São Paulo: Ed. Revista dos Tribunais, 1983. t. 23.

Tratado de direito privado. 3. ed. São Paulo: Ed. Revista dos Tribunais, 1984, t. $45,46,53$ e 54.

PREVIDÊNCIA SOCIAL. Anuário Estatístico da Previdência Social. Disponível em: <http://www.mpas.gov.br/conteudoDinamico.php?id=423>. Acesso em: 25 nov. 2012.

Regulamento da Previdência Social. Decreto 3.048/99. Disponível em: <http://www81.dataprev.gov.br/sislex/paginas/23/1999/3048.htm>. Acesso em: 27 maio 2012.

. Resolução 1.308/09, do CNPS, teve seu anexo substituído pela Resolução 1.316, de 2010 do CNPS. Disponível em: <http://www81.dataprev.gov.br/sislex/paginas/72/mpscnps/2010/1316.htm>. Acesso em: 27 maio 2012.

PRIEUR, Michel. Droit de l'environnement. 5. ed. Paris: Dalloz, 2004.

PRINCIPE de Précaution. Association des retraites du groupe (CEA). Disponível em: $<$ http://www.energethique.com/fiches_pdf/telechargement.htm>. Acesso em: 19 set. 2012..

PULINO, Daniel. Acidente do Trabalho. Ação regressiva contra as empresas negligentes quanto à segurança e à higiene do trabalho. Revista de Previdencia Social, Sao Paulo, v. 20, n. 182, p. 6-16, jan. 1996.

RAMAZZINI, Bernardino. De morbis artificum diatriba. Chicago: University of Chicago Press, 1940.

RAMOS, André de Carvalho. Direitos humanos em juízo. São Paulo: Max Limonad, 2001.

REALE, Miguel. Lições preliminaries de direito. 24. ed. São Paulo: Saraiva, 1999. 
REQUIÃO, Rubens. Curso de direito falimentar. 17. ed. São Paulo: Saraiva, 1998. v. 1. RODRIGUES, Marcelo Abelha. Instituições de direito ambiental. São Paulo: Max Limonad, 2002. v. 1.

ROMITA. Arion Sayão. Direitos fundamentais nas relações de trabalho. São Paulo: LTr, 2005.

ROUAST, André; GIVORD, Maurice. Traité du Droit des accidents du travail et des maladies professionelles. Paris: Dalloz, 1934.

RUSSOMANO, Mozart Victor. Comentários à Consolidação das Leis da Previdência Social. 2. ed. São Paulo: Ed. Revista dos Tribunais, 1981.

SACHET, Adrien. Traité théorique et pratique de la legislation sur les accidents du travail. 2. ed. Paris: Librairie de la société du recueil general des lois \& des arrêts, 1904. t. 1.

SALEILLES, Raymond. Les accidents de travail et la responsabilité civile. Paris: Librairie Nouvelle de Droit et de Jurisprudence, 1897.

SANTOS, Enoque Ribeiro dos. Responsabilidade objetiva e subjetiva do empregador. 2. ed. São Paulo: LTr, 2008.

SANTOS, Ronaldo Lima dos. Sindicatos e ações coletivas: acesso à justiça coletiva e tutela dos interesses difusos, coletivos e individuais homagêneos. 2. ed. São Paulo: LTr, 2008 .

Teoria das normas coletivas. 2. ed. São Paulo: LTr, 2009.

SARLET, Ingo Wolfgang. A eficácia dos direitos fundamentais. 7. ed. Porto Alegre: Livr. do Advogado, 2007.

SENADO FEDERAL. Assembleia Nacional Constituinte. Disponível em: $<$ http://www.senado.gov.br/publicacoes/anais/asp/CT_Abertura.asp>. Acesso em: 19 jun. 2011.

SILVA, José Afonso da. Curso de direito constitucional positivo. 8. ed. São Paulo: Malheiros Ed., 1992.

. Curso de direito constitucional positivo. 23. ed. São Paulo: Malheiros Ed., 2004.

. Direito ambiental constitucional. 8. ed. São Paulo: Malheiros Ed., 2010.

SILVA, Wilson Melo da. Responsabilidade sem culpa. 2. ed. São Paulo: Saraiva, 1974.

SÓFOCLES. A Triologia Tebana. Édipo Rei, Édipo em Colono e Antígona. Trad. Mário da Gama Kury. 10. ed. Rio de Janeiro: Jorge Zahar, 2002. 
SOUTO MAIOR, Jorge Luiz. A prescrição do direito de ação para pleitear indenização por dano moral e material decorrente de acidente do trabalho. Revista LTr, São Paulo. v. 70, n. 5, p. 535-547, maio. 2006.

; CORREIA, Marcus Orione Gonçalves. O que é direito social? In: CORREIA, Marcus Orione Gonçalves (Org.). Curso de direito do trabalho: teoria geral do direito do trabalho. São Paulo: LTr, 2007. v. 1.

STOCO, Rui. Responsabilidade civil e sua interpretação jurisprudencial. 3. ed. São Paulo: Ed. Revista dos Tribunais, 1997.

SUPERINTENDÊNCIA DE SEGUROS PRIVADOS - SUSEP. Conselho Nacional de Seguros Privados - CNSP. Resolução no 117, de 22 de dezembro de 2004. Disponível em: <http://www.susep.gov.br/menubiblioteca/seguro_pessoas_606>. Acesso em: 10 jun. 2012.

SUPERIOR TRIBUNAL DE JUSTIÇA. Disponível em: $<$ http://www.stj.jus.br/SCON/sumulas/toc.jsp?tipo_visualizacao=null\&livre=s\%FAmula +3 51\&b=SUMU>. Acesso em: 27 maio 2012.

Disponível

em:

$<$ http://www.stj.jus.br/portal_stj/publicacao/engine.wsp?tmp.area=44>. Acesso em: 11 nov. 2012.

Revista Eletrônica de Jurisprudência. Disponível em: $<$ https://ww2.stj.jus.br/revistaeletronica/ita.asp?registro=200801364127\&dt_publicacao=2 5/06/2009>. Acesso em: 09 nov. 2012.

- Súmula 278. Disponível em: $<$ http://www.dji.com.br/normas_inferiores/regimento_interno_e_sumula_stj/stj__0278.htm >. Acesso em: 24 nov. 2012.

Súmula 281. Disponível em:

<http://www.stj.jus.br/portal_stj/publicacao/engine.wsp?tmp.area=368\&tmp.texto=74914 \&tmp.area_anterior=44\&tmp.argumento_pesquisa $=$ s\%FAmula\%20281>. Acesso em: 11 nov. 2012.

SUPERIOR TRIBUNAL DO TRABALHO. Súmula 331. Disponível em: $<$ http://www3.tst.jus.br/jurisprudencia/Sumulas_com_indice/Sumulas_Ind_301_350.html. Acesso em: 22 nov. 2012.

SUPIOT, Alain. Le droit du travail. 3. ed. Paris: Presses Universitaires de France, 2008.

SUPREMO TRIBUNAL DE JUSTIÇA DE PORTUGAL. Disponível em: $<$ http://www.stj.pt/?idm=546>. Acesso em: 15 nov. 2010. 
SUPREMO TRIBUNAL FEDERAL. Ação Direta de Inconstitucionalidade (ADI 4066), Relator Ayres Britto. Disponível em: $<$ http://www.stf.jus.br/portal/processo/verProcessoAndamento.asp?incidente=2607856>. Acesso em: 26 set. 2012. Ação Direta de Inconstitucionalidade $n^{\circ}$ 997-4. Plenário, Rel. Ministro Moreira Alves. Julgado em 28/03/1996. Disponível em: $<$ http://www.stf.jus.br/portal/jurisprudencia/listarJurisprudencia.asp?s1=\%28997.NUME.+ OU+997.ACMS.\%29\&base=baseAcordaos>. Acesso em: 9 nov. 2012.

. ADPF 130. Rel. Min. Ayres Britto, j. 30/04/2009, Plenário, DJE de 06/11/2009. Disponível em: <http://www.stf.jus.br/portal/constituicao/artigo.asp\#ctx1>. Acesso em: 22 nov. 2012.

Disponível

em:

$<$ http://www.stf.jus.br/portal/geral/verPdfPaginado.asp?id=181116\&tipo=TP\&descricao= ADI\%2F3931>. Acesso em: 19 mar. 2012

Memória Jurisprudencial Ministro Pedro Lessa. Brasília: Coordenadoria de Divulgação de Jurisprudência, 2007. Disponível em: $<$ http://www.stf.jus.br/portal/cms/verTexto.asp?servico=publicacaoPublicacaoInstitucional MemoriaJurisprud>. Acesso em: 11 nov. 2012.

$$
\text { Súmula 230. Disponível em: }
$$

<http://www.dji.com.br/normas_inferiores/regimento_interno_e_sumula_stf/stf_0230.htm >. Acesso em: 24 .

Súmula $736 . \quad$ Disponível em: $<\mathrm{ttp}$ //www.stf.jus.br/portal/cms/verTexto.asp?servico=jurisprudenciaSumula\&pagina=su mula_701_800>. Acesso em: 19 set. 2012.

SÜSSEKIND, Arnaldo; MARANHÃO, Délio; VIANNA, Segadas; TEIXEIRA, Lima. Instituições de direito do trabalho. 20. ed. São Paulo: LTr, 2002. v. 1.

TRIBUNAL SUPERIOR DO TRABALHO. Disponível em: <aplicacao5.tst.jus.br/consultaunificada2/\#topoPag>. Acesso em: 09 nov. 2012.

Disponível em: <http://aplicacao5.tst.jus.br/consultaunificada2/jurisSearch.do>. Acesso em: 09 nov. 2012.

Disponível

em:

$<$ http://aplicacao5.tst.jus.br/consultaunificada2/jurisSearchInSession.do?action=search\&ba sename $=$ acordao\&index $=60>$. Acesso em: 10 nov. 2012.

TRIMARCHI, Pietro. Rischio e responsabilità oggetiva. Milano: Giuffrè, 1961. 
VENOSA. Sílvio de Salvo. Direito civil: responsabilidade civil. 4. ed. São Paulo: Atlas, 2004.

VERÇOSA, Haroldo Malheiros Duclerc. Curso de direito comercial 2: teoria geral das sociedades; as sociedades em espécie do Código Civil. São Paulo: Malheiros Ed., 2006.

VIVANTE, Cesare. Trattato di diritto commerciale: le obbligazioni. 4. ed. Milano: Francesco Vallardi, 1916. v. 4. 